
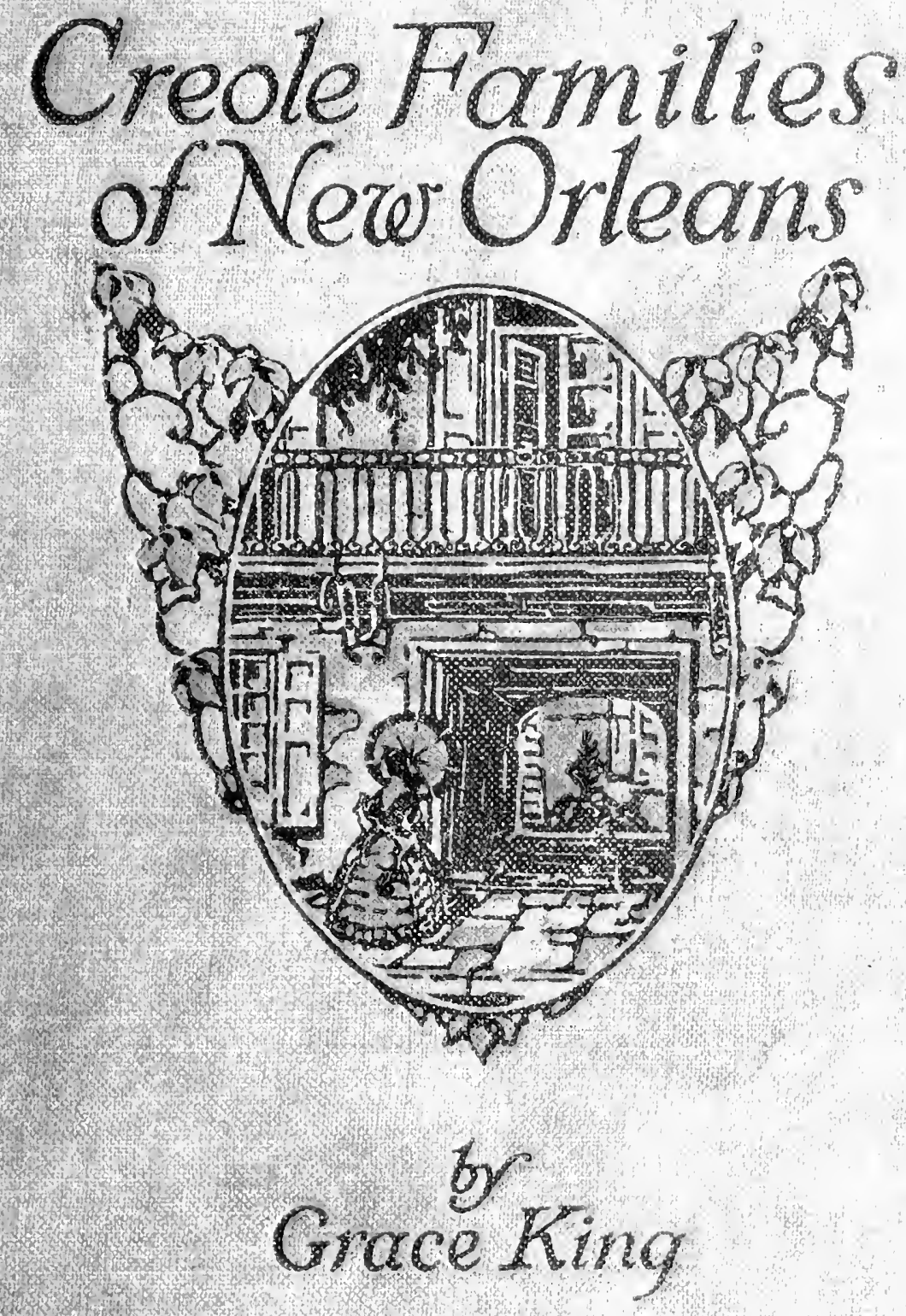


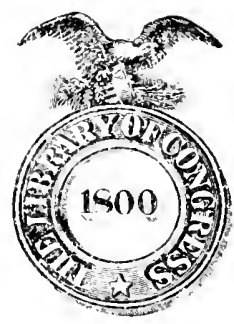

Class

Book

Coisyight 10.

COPYRIGHT DEPOST. 


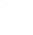



CREOLE FAMILIES OF NEW ORLEANS 


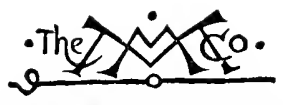

THE MACMILLAN COMPANY

NEW YORK - BOSTON - CHICAGO - DALLAS ATLANTA - SAN FRANCISCO

MACMILLAN \& CO., Limited

LONDON - BOMBAY - CALCUTTA

MELBOURNE

THE MACMILLAN CO. OF CANADA, LtD. TORONTO 



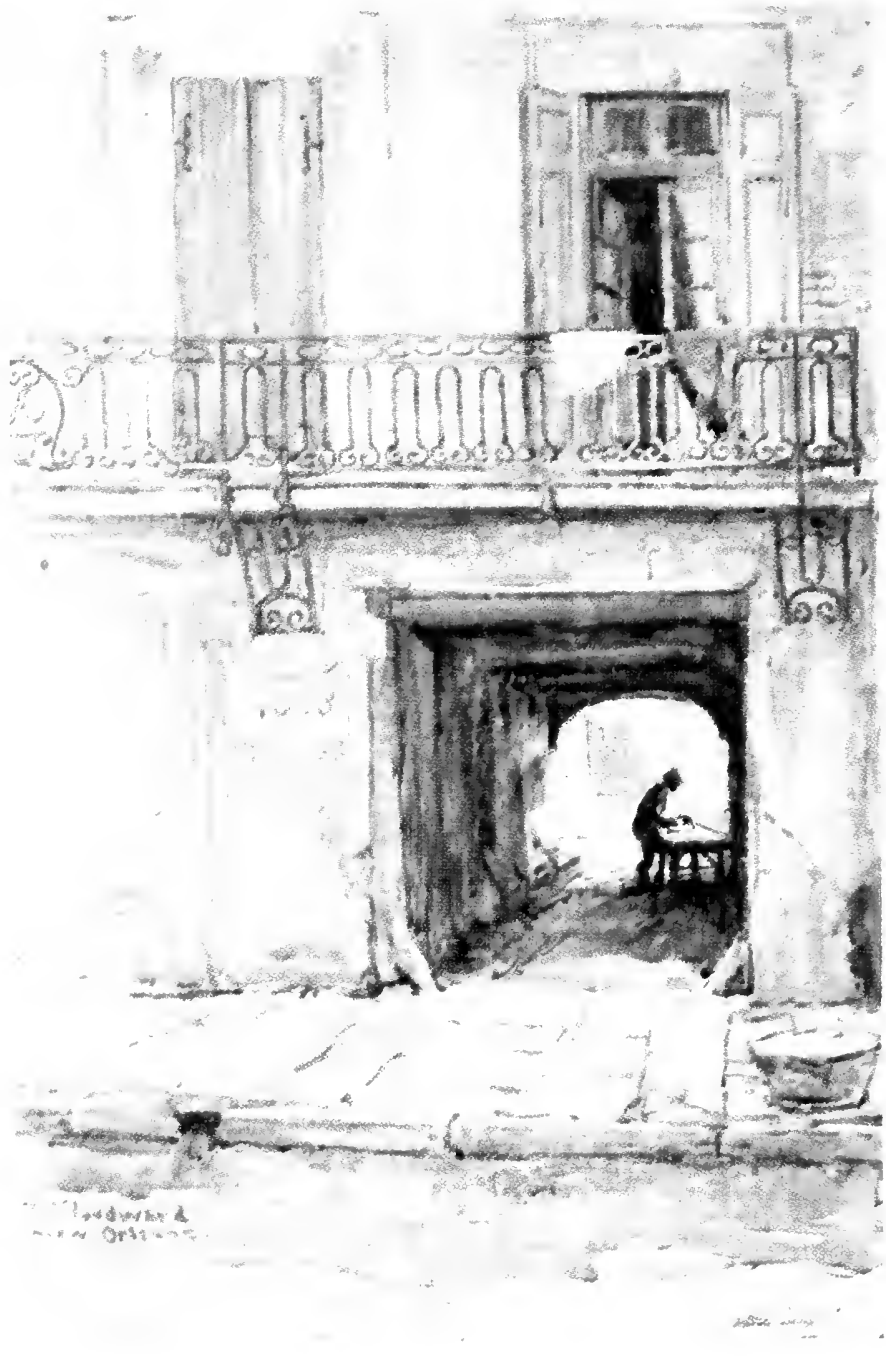




\title{
CREOLE FAMILIES OF NEW ORLEANS
}

\author{
By \\ GRACE ${ }_{\|} I N G$
}

\author{
WITH ILLUSTRATIONS BY \\ E. WOODWARD -
}

\author{
NEW YORK \\ THE MACMILLAN COMPANY \\ 1921 \\ All rights reserved
}


COPYRIGHT, 1921. HY THE MACMILLAN COMPANY

BET UP AND FLEC'THOTYPED. PUHLISHED MARCH, 1921

MAR . 31921<smiles>[AlH2]</smiles>

(c) $1411 \% 79$ 


\section{DEDICATION}

TO

ANNIE RAGAN KING

MY SISTER, COMPANION, FRIEND 



\section{PREFACE}

THIS book comes in response to a long-felt wish 1 of an humble student of Louisiana history to know more about the early actors in it, to go back of the printed names in the pages of Gayarré and Martin, and peep, if possible, into the personality of the men who followed Bienville to found a city upon the Mississippi, and who, remaining on the spot, continued their good work by founding families that have carried on their work and their good names.

It has been a pleasure to follow the traces they impressed upon the soil two hundred years ago, and to look through the vista of years that opened before them when they crossed the seas, trusting their names, their fortune, their faith to a new country.

Their genealogical records bear witness to their good blood; their "maintenances de noblesse" are still in existence, brought with them from France, in simple accord with what they considered a family necessity, as much so as a house and furniture. Traditions are still carrying a pale reflection of coloring and wavering outline of them. Little stories of them are still to be met hanging on a withering memory like shriveled berries on a tree that the next blast will rend from their twigs and scatter on the ground.

Some of the little houses they built are still standing; vital statistics - their baptisms, marriages 
and deaths-are still distinct in the old registers of St. Louis Cathedral. Bits of old furniture, jewelry, glass, old miniatures, portraits, scraps of silk and brocade, flimsy fragments of lace can yet be picked up scattered among the houses of the old streets they trod.

Much was in existence to ease the work of the chronicler, but much, alas! was found lacking. In some instances the trail grew too indistinct to be followed with confidence. Too late! Too late! The chronicler came too late. Family papers, so one excuse ran, had been destroyed in the "great fire" (of 1788). According to another the old trunk in which a careful grandfather had packed his documents had gone astray in the panics and flights of the family during the Civil War and had never been heard of since; or, sadder still, the faithful memory which carried the family record, grown aged and feeble, had lost its grip on the past, and had dropped its jewel out of its human setting, as many a fine stone has dropped from its setting, to be swept out with the débris.

The plan traced in advance for the chronicle was a modest one; comprised in time between Bienville and Claiborne, containing only the names mentioned in the historical reports of the period. But as the work and the pleasure of it progressed these limits had to be disregarded. Families ramified and prolonged their lives in an unforeseen way. The children of the best men under Bienville became the French heroes under Ulloa; and their children, pushing on through the Spanish Domination, became the strong men of the city under the American flag and fought with Jackson in the War of 1812. And still vIII 


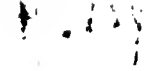

\section{PREFACE}

further their children fared on bravely to wear the gray of the Confederate Army, and onward still another generation advanced soaring higher and higher, and to-day we see them, as in the famous picture in the Paris Panthéon marching across the sky of glory, these fine old French names of Louisiana in the last (and may it be the last!) world war; speeding back to France in defense of their ancestral motherland to fight, suffer and die, and be buried there, giving back to French earth its dust!

The chronicler held her way through it all, too well pleased with the story confided to her to realize the end before her-the end of the book, not the end of the story. In truth, like the horizon, the end seemed to recede before her as she advanced, and so the last page of the book caught her unawares, as the last day of life does us all.

And so at the end of her book, the author finds, as doubtless she will do at the end of her life, that what she has accomplished bears but a pitiful resemblance to what she set out to do, and with "finis" bows her head in contrition for her many, many sins of omission.

Throughout the volume may be found in footnotes the grateful acknowledgment of the help accorded her on her way by which she has been able to accomplish the little she has done. But she would give more explicit mention of her gratitude to, first and foremost: The Louisiana Historical Society, for the freedom it gave her of its records; to Gaspard Cusachs, its president; to Heloise Hulse Cruzat, its corresponding secretary and ever ready helper in historical need; to Miss Freret, its librarian, whose intelligent assistance was never invoked in vain; to 
the Howard Memorial Library and its scholarly librarian, Mr. William Beer, and to his courteous assistants; to Mr. T. P. Thompson, whose rare collection of Americana was cordially placed at the author's service; to Mr. G. Lugano, the able archivist of St. Louis Cathedral; to Trist IVood, Esc., for steady and constant assistance in the collection of his family data; to Meloncy Soniat, Esq., for ever kind response to demands upon his time and manuscript store of precious genealogical records; to Mr. Elsworth Woodward, for his illustrations, and his cordial collaboration in heart and spirit with the aim of the book, which in this respect, at least, has been able to fulfill the author's highest expectations. 


\section{CONTENTS}

PREFACE

CHAPTER I

A la Nouvelle Orleans . . . . . . . 3

CHAPTER II

Marigny de Mandeville . . . . . . . 9

CHAPTER III

Bernard de MarignY . . . . . . . . 23

CHAPTER IV

Bayou St. Jean-The Dreux Family $\quad$. . . $\quad 59$

CHAPTER V

A Romance of The Bayou St. Jean . . . 67

CHAPTER VI

De Pontalba . . . . . . . . . . . 72

CHAPTER VII

Rouer de Villeray . . . . . . . . . 133

CHAPTER VIII

D'Arensbourg . . . . . . . . . . . 154

CHAPTER IX

De la Chaise . . . . . . . . . . . 159

CHAPTER X

LAFRÉNIÈRE . . . . . . . . . . . 169

CHAPTER XI

Labedoyère Huchet de Kernion . . . . 201

CHAPTER XII

De Livaudais . . . . . . . . . . . 212 
CONTENTS

CHAPTER XIII

Soniat DU Fossat

CHAPTER XIV

De la Vergne

CHAPTER XV

DE Boré

CHAPTER XVI

Gayarré 236 239

CHAPTER XVII

Charles Gayarré

CHAPTER XVIII

BouligNY

CHAPTER XIX

Almonaster

CHAPTER XX

De la Ronde . . . . . . . . . . . . 313

CHAPTER XXI

Chalmette . . . . . . . . . . . . 318

CHAPTER XXII

Cruzat

CHAPTER XXIII

Jumonville de Villiers $\cdot \cdot \cdot \cdot$
CHAPTER XXIV

LAVILLEBEUVRE

CHAPTER XXV

Grima . . . . . . . . . . . . . 350

CHAPTER XXVI

Forstall . . . . . . . . . . . . 357 
CONTENTS

\section{CHAPTER XXVII}

MaCARTy

368

CHAPTER XXVIII

De Buys . 383

CHAPTER XXIX

Canonge 392

CHAPTER XXX

Dubourg 397

CHAPTER XXXI

Charest de Lauzon . . . . . . . . . 406

CHAPTER XXXII

Bringier

CHAPTER XXXIII

TUreaud

CHAPTER XXXIV

Garrigues de Flaugeac-de Roaldes

CHAPTER XXXV

Pitot

CHAPTER XXXVI

RoffignaC 435

CHAPTER XXXVII

ST. Gème 443

CHAPTEP XXXVIII

Allain . . . . . . . . . . . . 446

CHAPTER XXXIX

Beauregard

CHAPTER XL

Alcée Fortier 



\section{LIST OF PLATES}

Frontispiece

Type of Wealthy Creole House of the French Period, Dumaine and Dauphin Streets-Servants, Quarters in the Rear . 138 Oaks at Versailles, de la Ronde Plantation-the Chalmette Battlefield to the Left . . . . . . . . 314

Vestibule of Grima House-Newel Posts of Brass, Balustrade of Mahogany . . . . . . . . . . . . . 356 Rue Dumaine . . . . . . . . . . . 408

\section{LIST OF ILLUSTRATIONS IN TEXT}

Ursulines and Chartres Streets. Built in the time of Bienvillenow demolished . . . . . . . . . . 11

Royal below Dumaine Street (used as Court House in 1815) where General Jackson was tried for contempt of court before Judge Hall . . . . . . . . . 41

Briquetté entre Poleaux (bricked between posts). Type of Pioneer house in country outside of New Orleans $\quad$. $\quad$. 69

Villa on Levee Road below New Orleans, facing West (now demolished)

The Napoleon House (with the belvedere) on Chartres Street back of the Court House . . . . . . . 121

Lit de Repos. A beautiful specimen of "Robert Adam" . . 241 Toilette Table. St. Domingo mahogany . . . . . . 267

Eighteenth Century Piano. Mahogany, inlaid with brass .275 Dauphine near Dumaine Street . . . . . . . 329

Empire Work Table of St. Domingo mahogany and brass . 371

Jefferson Street, back of Pontalba buildings . . . . . 375 Toulouse Street, near "Old Levee" Street . . . . . . .431 Porte Cochère on Chartres Street $\quad$. . . . . . . . . . . 439 Rampart and St. Peter Streets . . . . . . . . 457 



\section{CHAPTER I}

\section{A LA NOUVELLE ORLEANS}

"Orléans, Gentilly,

Pontalba, Marigny,

Bourbon! Bourbon!"

These are the words that come to me (The haunting turn of an old refrain)

From the Siren City beside the sea,

Child of the valour of France and Spain.

She sits there weaving her olden spells.

The years through her lissom fingers run

To form but a chaplet whereon she tells,

The names of her lovers, one by one!

Gayoso, Galvez, Bouligny,

Caso-Calvo, Derbigny!

Don Almonaster's bells intone:

For Bienville and for Sérigny,

For D'Iberville, for Assigny,

They make incessant moan.

"Orléans, Gentilly,

Pontalba, Marigny,

Bourbon! Bourbon!"

- William McLennan.

THE old Creole families of New Orleans date from 1 the foundation of the city, and even before thatfrom the settlement of Mobile, Dauphin Island and Biloxi, their good old names figuring in the lists of military, naval and civil officers who followed Iberville to the discovery of the Mississippi and remained with Bienville to hold on to the French possession of it. 
It may in fact be said that New Orleans brought her population into the world with her, or rather, was furnished in advance with it, as a baby is with a layette, or a bride with a trousseau. Like a layette or a trousseau, the material from which the population was made was of the finest and strongest, and it has worn well.

The men under Bienville who, for twenty years, had borne the brunt of the hardships of colonial settlement in a savage country, were well content to follow him to the last goal in their enterprise, the foundation of a city on the Mississippi-not a fort nor a settlement, but a city-whose image and superscription was to be "France, her sights and sounds, dreams and laughter."

They builded better than they knew, as we can judge to-day. The ground selected was quickly cleared of its forest; the streets were laid out and named; homes were built (to continue the feminine simile) just as the corbeille is still prepared to contain the layette and trousseau.

Each square formed by the intersection of the streets was divided into four allotments, and in each allotment was erected a house-a low, square, eight or four-room cottage built of split cypress logs, raised a few feet above the ground, with high ridged roof covered with bark, and with solid cypress doors and windows; the type of building that has perpetuated itself in the city. It was built to last and it did last, for a century and a half.*

The careful Bienville provided also a site for a

* A specimen was spared until recently, when it was demolished in obedience to some civic decree. It was situated on a corner of Chartres Street opposite the site of the old Ursuline Convent. 
church, and pre-empted the space in front of it for a Place d'Armes. The first church was also of the most primitive form of construction-a low, oblong building, only large enough to hold its absolute necessities, as it were, of divine worship; behind it was the graveyard. As it was planned in 1720 it is, in a general way, seen to-day.

The squares were surrounded by deep ditches, which, when filled with water, made little islands of their enclosures and so, in New Orleans' common speech, a square is still called an "islet."

The first census of the city, taken in 1726, gives the names and addresses of its first inhabitants. To cite a few of them: on Old Levee Street (as it is called to-day), the "Rue du Quay" of 1726, were the hospital, the "direction" or official building, the house of M. Pauger, the engineer who laid out the city; of M. Trudeau and his six children; and that of " $M$. de Noyan in which Petit de Levilliers and his wife resided."

On Chartres Street was the house occupied by the Jesuits, and the "large house where lived de la Chaise, his wife and two children"; St. Martin, with his wife and three children; Marest de la Tour; and Bellair.

On Condé Street (Chartres, below the Cathedral) was the "small house of Joseph Carriere, where he stops when he comes to town"; and the houses of de Lassus and M. de Boisbriant, Commander General.

On Royal Street, the trades people seemed to cluster-carpenters, cabinet makers, a wig maker, a shoemaker, a wagon maker, a "chandelier" (candle maker), armorers. 
Jean Pascal, with "fat wife and child" lived alongside a large house belonging to $\mathrm{M}$. Chauvin de la Frénière, "where he stays when he comes to town" (his plantation was above the city); then followed the house where M. Fazende, the Councillor, lived "with wife and child, mother-in-law and brother-inlaw."

On Bourbon Street, we find the surgeons Michel Brosset and Pouyadon de la Tour; the rest of the street being filled up as was Royal with trades people, each one provided with wife and children and designated by a sobriquet-"la Bouillonerie" called "la Douceur"; Joseph Cham called "la Rose."

Bienville Street was more aristocratic. On it stood the mansion of the Governor and the houses of M. de Chavannes, Secretary of the Council; of M. Fleuriau, Attorney General; of Dr. Alexandre, Surgeon Major of the Hospital, etc., etc.

On St. Philippe Street, lived Chesseau, the "cannonier" of the town. On Barracks Street, St. Pierre, Dumaine, Ste. Anne, and Orléans Streets, lived other useful members of the community.

In 1726 , the population numbered 880 , of which 65 were servants and 129 slaves. There were only ten horses in it.

By this time the city had become the capital of the province, and the seat of government, with the legal institution of a Superior Council, whose first Councillors were sent from France. A convent of Capuchins had also been established for the service of the Cathedral.

Tall, pointed picket fences surrounaed the houses, built as was the custom in France "entre cour et jardin." In the earliest records, statistical items are 
accompanied by pretty accounts of the flower gardens of the city, planted with seeds brought from France, and cuttings shipped from Havana and Porto Rico. The oleanders that bloom in the Place d'Armes to-day, doubtless are descendants of original stocks. The tall fences were reinforced by inside hedges of orange trees, the sour variety being preferred as more hardy; the ripened fruit, glittering like lighted lanterns in their dark foliage, over the sharp-pointed tops of the pickets; their blossoms showering down on the pathway outside, embalming the air with heavenly perfume. At the back of the houses, across the yard, were the quarters of the servants, the kitchen and household "offices."

There was apparently little "roughing it" during these early days of the city's life. Indeed, compared with life to-day, the little cypress cottages and their households are to be envied by the brides of to-day as they look back upon the brides of two centuries ago, who arrived from France, trailing their illustrious heritage of family names behind them.

They brought with them for their new homes an outfit of furniture, linen and glass; and for themselves silks, satins, laces and jewelry. They found awaiting them the best of servants, selected with a careful eye from a market stocked with samples of the best tribes of Africa, and bought without regard to price; and provisions from the rich country about them-fish, flesh, game, vegetables and fruits; with wine flowing generously and good company; their own language, the good manners of the Old World, and a society that, although gay, was kept within the bounds of the proper and the discreet by the rigid maintenance of the etiquette of society in Paris, and the strict 
enforcement of French laws for preserving the purity of blood and family prestige.

Four records of baptism on each side were required before marriage between any loving pair could be solemnized. Parentsand grandparents had to make proof of legitimacy by certificates from the church, and other and more particular enlightenment was ascertained in private ways. The scrutiny was keen and inexorable. 


\section{CHAPTER II}

\section{MARIGNY DE MANDEVILLE}

T $\mathrm{N}$ the chronicles of the old Creole families of New 1 Orleans, the name of Marigny de Mandeville stands first. In truth, the family antedates the city itself; and through two centuries of its life contributed active workers to its history.

In the list of officers selected to accompany Iberville to the discovery of the Mississippi in 1699, appears the name of a Josselin de Marigny, "Enseigne en Second de la Companie d'Arquian." Bienville was midshipman on the same vessel. It is not yet made clear whether Josselin was connected with the founder of the Louisiana family, although the coincidence of the surname and the date is too striking not to suggest the probability of it. The name of Josselin occurs but this once in our annals, while "M. de Marigny" is mentioned in the chronicles of the earliest explorations of Bienville around Mobile in 1704.

The Louisiana family is usually traced to Pierre Philippe, Sieur de Marigny de Mandeville, to whom were issued letters patent of nobility, signed Louis and Phélipeau, dated Paris, 1654, and registered "à la Cour des Aydes et Comptes de Rouen, 1656." By another letter patent issued at St. Germain en Laye, 1671, signed Louis and Colbert, the title of Sieur de Hautmesnil was conferred upon the son, Jean Vincent Philippe, for services rendered, "en la Nelle, France." 
The first of the name of whom we have any sure data in Louisiana is François Philippe de Marigny de Mandeville, Chevalier de St. Louis, born at Bayeux, Normandy.* He married Madeleine Le Maires, daughter of Marguerite Lamothe, native of Paris, Paroisse St. Sulpice, and of Pierre Le Maire, probably of the same family as the Missionary Geographer, François Le Maire, who wrote a "Mémoire sur la Louisiane 1718," and drew a map of the country.

François Philippe was an officer of Infantry in Canada in 1709, and afterwards "Commandant des Troupes en Louisiane." In 1714 he received his commission as Captain and later was made Chevalier de St. Louis. He was placed in command of Fort Condé near Mobile, where he is recorded as serving without pay. On the first map of Mobile, there is an allotment marked "M. de Marigny."

In 1724 the Company of Mandeville is mentioned among the military companies stationed at New Orleans. Subsequently he was made Major de Place, or Military Commandant there. It is presumable that he was with Bienville when the latter had the site of New Orleans laid off by the Royal Engineers, and that he witnessed its slow upbuilding and its gradual growth of population.

By 1724 the city's struggle, not for existence but for official recognition, was over; and Bienville's ambition that it should be the capital of the province was realized. It was made the seat of government. The Superior Council had been removed thither from

* From the "Biological and Genealogical Notes concerning the Family of Philippe de Mandeville, Ecuyer Sieur de Marigny, 1709-1880," by J. W. Cruzat.

Louisiana Fistorical Publications, Vol. V, 1911. 


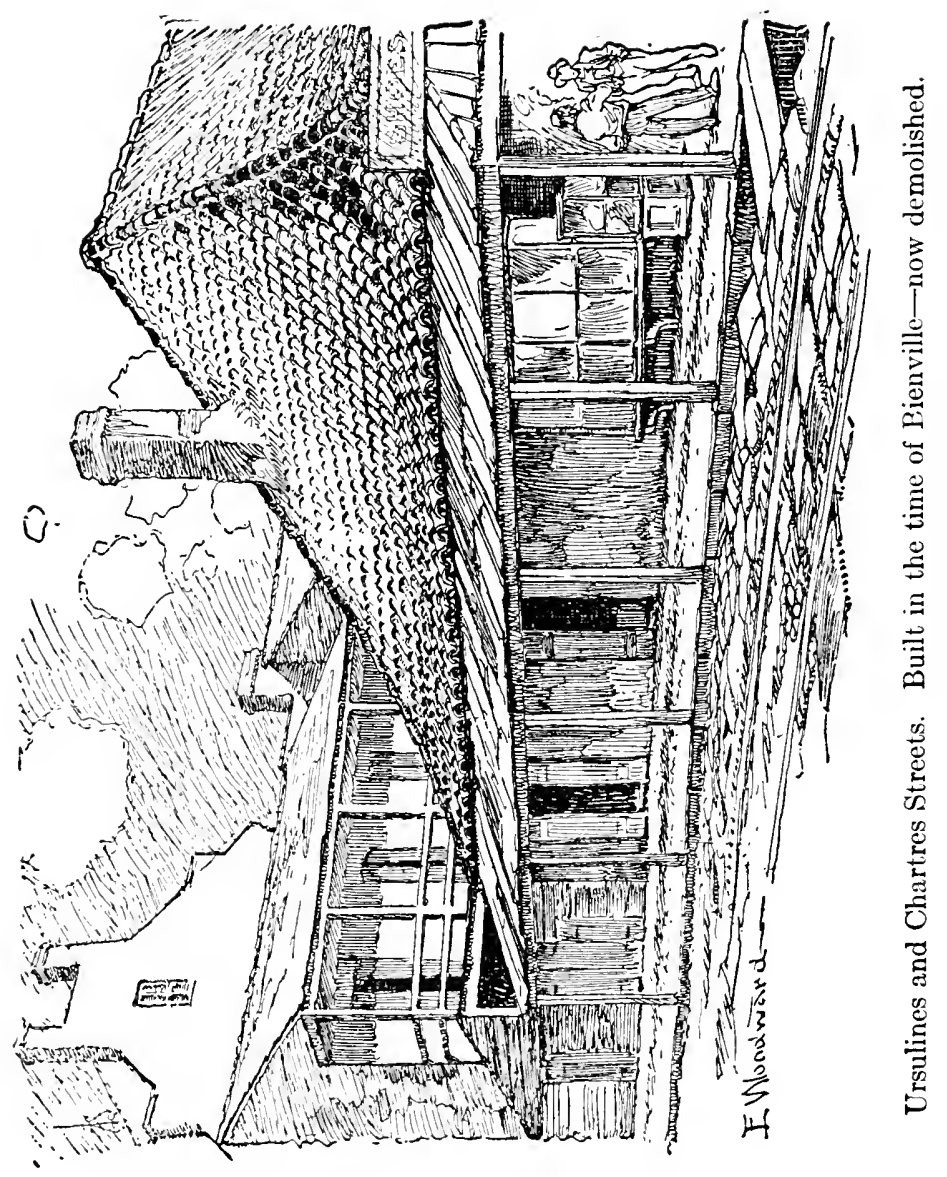



Biloxi, and it held its regular sittings in the Government Building facing the river. A hospital, the barracks and other public buildings for military and civil offices had been erected.

The Chapel of St. Louis, the precursor of the present Cathedral, had been built, with the necessary house for its priest. The allotments of ground made around the Place d'Armes had been surrounded by ditches and raised walks, and were being gradually filled by the gardens and low, four-roomed cypress cottages that constituted the first residences of its citizens.

It was doubtless in such a house that $M$. de Marigny lived, with his wife and two children, on Chartres Street, according to the Census of 1726 . He died here in 1728 and was interred, as a mark of distinction, in the Parish Church of St. Louis. The Marigny tomb is still to be seen, marked by a large white marble stone, which bears the Marigny coat of arms and the inscription of three generations of them, written in French. It is situated on the left aisle of the church, at the foot of the altar of "Our Lady of Lourdes."

In 1729, his widow married François Ignace Broutin, "Capitaine Ingénieur du Roi en cette colonie et Commandant des Natchez." Of this marriage were born several children; among them two daughters. One married Jean Delfau de Pontalba, and the other Louis Xavier de Lino de Chalmette, thus uniting three of the most important families of New Orleans.

By her marriage with Marigny, Madeleine Le Maire had one son, Antoine Philippe, Ecuyer, Sieur de Marigny de Mandeville, Chevalier de St. Louis. He was born in Mobile in 1722, and had for god- 
parents Chateaugué, brother of Bienville, and Marguerite le Sueur, wife of Nicolas Chauvin de Lafrénière, mother of the celebrated Lafrénière, the famous patriot who was executed by O'Reilly in 1769.

Antoine Philippe married, in 1748, Françoise de Lisle, presumably the daughter of Guillaume de Lisle, Geographer to the King, whose maps of Louisiana, 1703-1712, ruled for a long period the geographical world of France as the best and, in fact, the only authoritative source of information on the subject of the Mississippi and Louisiana.

Antoine Philippe wrote a "Mémoire sur la Louisiane," and became himself an enterprising explorer and expert geographer. In the words of Bossu, the historian, "M. de Marigny de Mandeville, an officer of distinction, undertook with the consent of the Governor to make new discoveries around the Isle of Barataria, and it was in connection with this that he worked to produce a general map of the Colony. This officer made, at his own expense and with the indefatigable zeal of a worthy citizen, the exploration of this unknown country."

According to his portrait in the Gaspar Cusach collection of the Louisiana Historical Society, Marigny was a refined, aristocratic, scholarly looking officer, wearing a péruque and queue. He enjoyed with the rest of his fellow citizens the calm and equable administration of the Marquis de Vaudreuil, who succeeded Bienville as Governor of the colony in 1743 , when in spite of much civic friction and the continual insubordination of the Indians under the encroaching British influence over them, Louisiana grew in strength and importance. The city began 
to take on some show of wealth and social pretension, while the population increased measurably.

But when the courtly Vaudreuil left the colony in 1783 , he was succeeded by M. de Kerlerec, a bluff Captain in the Royal Marines, whose character and methods of government were in violent contrast to those of the noble Marquis. The city under Kerlerec suffered all the discomforts of a violent housecleaning at the hands of a vigorous shrewish housekeeper, who quarreled and found fault with all subordinates. The contention between him and his Commissary, Rochemore, broke all the official etiquette that had hitherto restrained such quarrels, and the innovation ensued of the participation in it of the wives of the principals - Madame de Kerlerec and Madame de Rochemore. Each one had her feminine partisans, who (as ever with such partisans, zealous to indiscretion) warred so well that soon the whole social element of $\mathrm{New}$ Orleans was divided into two hostile camps.

In default of newspapers the publicity of accusations and insinuations was obtained by means of pasquinades and lampoons affixed to the corners of the streets. The mordant wit of these pleased immensely and was enjoyed by each side in turn. Unfortunately, no specimen of these was preserved, to the great regret of succeeding historians.

The officers of the garrison, naturally, did not remain neutral. Marigny distinguished himself among the keenest supporters of Rochemore against Kerlerec, who with military promptness arrested him and a bunch of his supporting brother officers and summarily shipped them to France on a departing vessel.

Rochemore, the Commissary, was sent to France 
at the same time, as was Jean Baptiste d'Estrehan, the Royal Treasurer of the colony, described by Kerlerec as being "too rich and dangerous." "But if I send away all the mauvaises têtes here," he wrote, "what would remain of the population?"

On his arrival in France, Marigny petitioned Choiseul to know the cause of his ill treatment, accusing Kerlerec of abuse of power and other violations of duty. To his petition he annexed two certificates, one from Bienville and one from Vaudreul, containing the highest commendations of himself.

The officers were pardoned on promise of good behavior, but the arrival shortly afterwards of Kerlerec himself in Paris (recalled to answer the charges against him) proved too much for their submissive disposition. With vindictive pens they wrote and published a pamphlet against their adversary, who replied so promptly and effectively that the officers were now sent to the Bastille and kept there for a year and a month. On their release, nevertheless, they returned to the charge, and making good their accusations against Kerlerec, the latter was condemned to exile and was ordered not to approach Paris nearer than thirty leagues.

Antoine Philippe returned to New Orleans and died there in 1779. He was buried in the St. Louis Cathedral, his name being second on the family tombstone.

By his marriage with François de l'Isle, Antoine de Marigny had two children: Pierre Enguerrand de Marigny, born in New Orleans in 1750, and Madeleine Philippe de Marigny.

The name Enguerrand recalls the celebrated 
Enguerrand de Marigny, Superintendent of Finance under Philippe le Bel in 1315, who was hanged on the gibbet at Montfauçon, after an iniquitous trial. The name, however, was dropped by his Louisiana namesake, who retained only the less illustrious Pierre Philippe of his immediate ancestors. He married Jeanne Marie d'Estréhan, daughter of Jean Baptiste d'Estréhan, Treasurer of the King, a Frenchman of distinguished family, who had filled the post of Royal Treasurer until Kerlerec, ostensibly from motives of prudence, ordered him back to France as being "too rich and dangerous." D'Estréhan's wife was Catherine de Gauvry. (A Captain de Gauvry came to Louisiana and served under Bienville in Mobile in 1720.)

Jeanne Marie d'Estréhan had a sister married to Etienne de Boré (grandfather of Charles Gayarré the historian), and another to Favre d'Aunoy, the French Royal Commissioner at New Orleans. Her brother married a Miss Maxent, who subsequently became the wife of Governor Bernardo de Galvez, thus binding by marriage more of the great French families together.

Of Marigny's wife we have no record, but Charles Gayarré has contributed to literature a pretty description of her sister, his grandmother. And it is not of record or tradition that any of the d'Estréhan sisters differed from Madame de Boré, a perfect type of the grande dame of St. Cyr, where she was educated.

Pierre Philippe de Marigny was too young at the time to take part in the revolt against Ulloa; and, therefore, had no share in the glory of the French patriots, who sacrificed their lives in their devotion 
to France. As he grew to manhood under the Spanish Domination, he accepted it calmly, conforming successfully to its régime, with which he was connected intimately as brother-in-law to Governor Galvez.

He was made Colonel of Militia, and put in command of the new Spanish town of Galvezton, near Baton Rouge. He became a friend and associate of Carondelet, whom he knew as a man of character and ability; but, according to his son Bernard, he knew how to oppose him when he thought it necessary. At the time when the inimical demonstrations of the West against Spain threatened the security of the city, Carondelet called upon all Louisiana to take arms, and he had the militia organized by Philippe de Marigny de Mandeville.

He it was who built up the colossal Marigny fortune, reputed to be seven millions at the time of his death. To concessions obtained from France by his father, he added large concessions granted to him by Spain, and, profiting by opportunities such as always are offered during a period of political reconstruction to speculators, he invested in real estate, buying large plantations above the city on the river front, which, added to his large plantations below the city, made him not only the greatest landowner of New Orleans, but also its richest citizen.

Marigny purchased also a princely tract of magnificently wooded land on the opposite shore of Lake Pontchartrain from New Orleans which, in honor of its growth of trees, he called Fontainebleau. He built here the wooden cottage (of the modest New Orleans type) which still exists, where with his family and a great retinue of servants he was wont to pass the hot 
months of summer. His city residence, as described by those who remember it, was situated in local parlance "on the levee," facing the river, in the territory of the old Marigny plantation, somewhere (vaguely located) between the Esplanade and the Champs Elysées, where he lived in princely state with his large family, surrounded by a village of slaves.

The house is remembered by those who have seen it, as the usual plantation mansion of Louisiana, of massive timber, with a gallery supported by brick pillars. It was remarkable chiefly for its size, which was that of two ordinary large mansions joined together. An avenue of trees led from the levee to the front portal. In this primitive sort of palace, he had the honor of receiving and entertaining, in 1798, the Royal Princes of France, the Duc d'Orléans (later King Louis Philippe) and his brothers, the Duc de Montpensier and the Comte de Beaujolais, the sons of Philippe Egalité.

The lavish luxury displayed during this entertainment of Royalty, the splendid banquets and balls to which all the aristocracy of New Orleans was invited, the utter disregard of money expenditure (as it has come down to us in family stories) must have astonished the young Princes, so short of money themselves, even more than it did the simpleminded citizens of that time.

The banquets offered by the Spanish Governor are never mentioned in comparison with those of the splendid Philippe de Marigny-not only in New Orleans, but in Fontainebleau, where he also entertained his guests. The golden memory of them is still preserved piously in the little town of Mande- 
ville, which naïvely claims for Fontainebleau the original honor of the fabulous (it is hoped) story that at a banquet given to the Princes, the cigar lighters passed around after dessert were hundred dollar bills! But the same incident, it must be confessed, is still claimed by New Orleans, where it is recalled with a vividness that has not been suffered to become dull during the two centuries of brilliant functions that no doubt succeeded it.*

The dainty Sèvres sugar bowl, that was passed with the black coffee on this or a similar occasion, is still preserved and shown by one of the most charming descendants of the Marigny family. She remembers, as if she had seen them herself and not through the eyes of a grandmother, the captivating manners of the young Princes during their three months' visit to the city and their pleasant sociability with the ladies of Society, whom they visited in the great lumbering Marigny carriage of the time, with the nimble black footmen jumping down to unfold and fold up the hanging steps when the august young men descended and ascended.

But in all that is related about this glorious society event of the past, and of the charming Princes and beautiful Creole ladies, there is, strange to say, no hint or suspicion of a romantic episode. For once poetry and romance abstained from intermeddling in the affairs of youth, and Cupid stayed his hand which is, let us acknowledge with all sincerity, to

* Bernard was once asked about the truth of a similar story. It was said that a lady, having dropped a coin on the floor at a card party, he had lighted a five-dollar bill as a taper in looking for it. He replied: "I know I have been a fool about money; but I was never fool enough to burn it." 
the honor of Madame de Genlis and her system of education.

When the Princes took their leave, they were escorted to the Balize by numerous friends and by their host, who added to his other royal generosities the loan of a royal sum of money (to which, it is said, Enoult de Livaudais, his son-in-law, as generously and imprudently contributed).

Pierre Philippe de Marigny, the magnificent and courtly citizen, died in 1800 , two years later, at Fontainebleau. His body was transferred in state to the home of his kinswoman, Madame Don Andres Almonaster, whence it was interred in the Cathedral, according to his funeral notices, tacked, as was the custom, on the door of the Cathedral or the corners of the streets. One of them has been preserved.

\section{"Messieurs et Dames:}

"Vous êtes priés d'assiter au convoi et à l'enterrement de feu M. Dn. Pedro de Marigny, Colonel de milice, décédé' cet après midi, à une heure, dans sa maison.

"L'enterrement se fera demain a 7 heures du matin. Son corps sera exposé chez Madame Dn. Andres Almonaster.

"Nouvelle Orleans, ce 14 Mai 1800.

"Un de Profundis S. V. P."

His name is the last one recorded on the family tombstone in the Cathedral.

He left five children:

(1) Antoine, born in 1773.

(2) Jean, born in 1781, died without issue.

(3) Bernard, born 1785; his godparents were the high and mighty personages, Xavier Delfau de Pontalba, and Félicité, Comtesse de Galvez. 
(4) Marie Céleste, baptized February 2, 1786; her godparents were Etienne de Boré and Céleste Macarty, wife of Governor Miro. She married Jacques Enoult de Livaudais.

(5) Antoine, born in 1787; no issue. 


\section{CHAPTER III}

\section{BERNARD DE MARIGNY}

T $T$ was the third child of Philippe Bernard Xavier 1 de Marigny de Mandeville, who represented the family during the last century; and who is the hero par excellence of New Orleans' social traditions; who, we may say, was to the Marigny family what the final bouquet is to a pyrotechnical display. He, more than any of his family or men of his time, is responsible for what we call to-day the Creole type; originating the standard of fine living and generous spending, of lordly pleasure and haughty indifference to the cost; the standard which he maintained so brilliantly for a half century, until, even to-day, one receives, as an accepted fact, that not to be fond of good eating and drinking, of card playing and pretty ladies; not to be a fin gourmet, not to be sensitive about honor, and to possess courage beyond all need of proof is, in sober truth, if such a truth can be called sober-not to be a Creole.

It was a standard that required the greatest fortune Louisiana could produce to maintain it. It ravaged the great wealth of Marigny himself, and ruined many and many of the old families who tried to follow in his aristocratic footprints and who arrived at poverty as Bernard did but without the prestige that distinguished him to the end. The handsome furniture, cut glass, porcelain, jewelrythe real lace, and delicate bric-a-brac of all kinds 
that have delighted the eye for decades past in the antique shops of New Orleans, are indubitably remnants of the wreckage of the fortunes that went to pieces in the wake of the Marigny standard of living. And as in the course of two centuries the Marigny family intermarried only with the best families in the place, and, as we shall see, all of the old families bear one or two of the Marigny names as the proudest fruit of their genealogical trees - the name has come to be in the city's estimation as sure a guarantee of social prestige as it is of artistic beauty and genuine value when attached to mere objects of domestic use.

Elegant of manners, polished of tongue, fearless of opinions, Bernard was the kind of man that shone in conversation, particularly at the banquet table, sowing repartees and witticisms that have sprouted ever since in the memory or imagination of his fellow citizens, until they have attained a growth and luxuriance of bloom out of all proportion to our powers of belief to-day. And it is always repeated with apparent conviction that the best and greatest number have been lost-as seems always to be the fate of good stories. Those who were born too late to know him have always regretted the lost opportunity of meeting in person a hero who would have graced the Court of Louis XIV - or at least the pages of Alexandre Dumas.

Upon Pierre Philippe's death, his kinsman, de Lino de Chalmette, assumed the management of his vast estates and the guardianship of the fifteen-yearold Bernard. The latter charge proved not a light one for the staid and prudent godfather. The youth, indulged and spoiled, reared, according to 
local gossip, like some rich nobleman's son, had from childhood known no other authority but that of his own will and pleasure. Precociously wild and extravagant, with unlimited wealth now at his command, more was feared than hoped from his future.

De Lino had recourse to the time-honored expedient, ever adopted by troubled guardians, of a change of environment. He sent his ward to Pensacola, and placed him there under the care of the great millionaire merchant, Panton, of the historical firm of Panton and Leslie, whose commercial transactions at the time amounted to a virtual monopoly of the Indian and European trade of the southern portions of America. The young Creole, however, was given such a handsome allowance of money and liberty by his tutor, and he made such good use of it for his own pleasure, that he soon scandalized the austere Scotchman and Protestant, Panton, who returned him after a short experience to New Orleans.

But Chalmette had still another resource whereby he hoped to make a staid business man of his charge. He sent him to England, and placed him under the care of Mr. Leslie, the resident partner of the firm in London. Two anxious letters* on the subject by Chalmette have survived in a mass of Panton family correspondence.

$\mathrm{He}$ writes frankly to Mr. Forbes, a member of the firm, who apparently had intervened in the affair:

"The friends who have informed you unfavorably about the young man, have not misled you. He has been guilty of irregularities of conduct, errors caused rather by his youth than by

* Obtained through the courtesy of Héloise Crozet, a descendant of Mr. Panton. 
corruption of heart. Besides, at the time he was under the guidance of a most respectable father, but one full of weak indulgence toward him which contributed not a little to his ill conduct. I have made him understand your fears about introducing him. He feels them sensibly. But his expressions and his increase in age, his promises to me, and his good conduct since the death of his father, are strong reasons for me to hope that he will become one day, an agreeable and intelligent member of society."

\section{Some days later he writes:}

"I am writing to Mr. Leslie acquainting him with the character of the young man. I am giving him full power to place him in the college or seminary he selects as the most proper. I also leave to his will all that pertains to his clothing and small expenses. In fact, I make over to him all the authority I have as his tutor, approving in advance whatever measures he may adopt in regard to him. I tell $\mathrm{Mr}$. Leslie also, that if the 1200 gourdes (dollars) that I have settled as Bernard's pension for the first year, do not suffice, I pray him to supply the deficit, and so to advise me that I may return his advances."

\section{He explains:}

"According to what information I have been able to gather from different persons here as to the expenditures necessary to obtain a good education, lodging, food and small pleasures for a young man in Louisiana or London, I am assured that twelve hundred dollars will suffice to procure comfortable ease. He must keep within it the first ycar at least . . Bernard knows all this and seems disposed to fulfil my desires.

"De Lino, April 29th, 1808."

Later he thought of increasing the allowance to two thousand dollars, whenever Mr. Leslie assured him that the young man was making good use of the money, for it would be dangerous for him to possess large means in a city which offered so much temptation as London.

Introduced into the best society by Mr. Leslie, 
who himself was connected with old and aristocratic families of Scotland and England, even with the Gordons then shining in the luster of their luminary, Lord Byron, Bernard de Marigny gained in London much in the way of the English polish of manners of the time. He gained also the fine fluent use of good English that distinguished him through life, although his accent remained amusingly bad. (In social life and with his family, he spoke only French.) Of business methods, however, he learned naught that was profitable. In short, he made so many visits to Paris, spent money so lavishly on his pleasures, and his pleasures increased so alarmingly in moral and financial cost, that his alarmed tutor recalled him in 1803 to the bosom of his family.

His portrait at this time represents him with the clean-shaven, handsome face of the full-blooded young Englishman of the day, dressed with the foppery of a dashing young fellow; his eyes, large and handsome, bespeaking intellect; his handsome mouth and full lips showing the devotion to the good things of life which he always professed, to which indeed he showed a lifelong fidelity. His figure was symmetry itself; he was about five feet ten inches tall and admirably proportioned.

Gayarre, his cousin, gives this glimpse of him:

"One day as our family, seated on the front piazza, was enjoying the balmy atmosphere of a bright May morning, there came on a visit from New Orleans, MI. de Boré's favorite nephew, whose name was Bernard de Marigny. He was one of the most brilliant and wealthiest young men of the epoch. He drove in a dashing way up to the house in an elegant equipage drawn by two fiery horses. Full of the buoyancy of youth, he jumped out of his carriage and ran up the broad steps of the brick perron that ascended to the 
piazza. As he reached the top of it, he said, with a sort of familiarity, "Bonjour, mon oncle, bonjour!"

Marigny was at this time eighteen, and master of himself and of his fortune. A most favorable occasion for the employment of both was at hand. Louisiana was to be transferred back to France. M. de Laussat was sent to New Orleans, with the title of Colonial Prefect, to represent France and receive the province from the Spanish Commissioners. He brought a letter of introduction to Bernard Marigny from Delfau de Pontalba, who suggested to his young kinsman to tender the use of his house to the French Commissioner. This advice was at once acted on; and de Laussat, his wife - "a woman of remarkable beauty and wit," as Marigny describes her, two young daughters, his staff of four officers and his secretary were all entertained in this great house on the levee, in which Philippe de Marigny had entertained the Royal Princes.

Bernard proved the equal of his father in bounteous hospitality, and surpassed him in the brilliancy of the fêtes given in honor of his guests. He himself was tendered a seat at Laussat's table as well as entrée to his salon, and he became one of the intimates of the circle.

He participated in Laussat's anxiety over the delay of General Victor's arrival with the army to take military possession for France, and was a witness of his extreme disappointment when he received the order to cede the province with as brief delay as possible to the Commissioners of the United States. The courier who brought the dispatch was a dashing young French officer named Landais who, charged to avoid the usual route and conveyance from 
Washington, rode at full speed through the Indian territory to New Orleans.

Preparations were at once begun for the ceremony of the cession and the fêtes and entertainments to celebrate the event were renewed and prolonged. Salcedo, the Spanish Governor, who was old and infirm, wished to defer the ceremony until he had heard from his government, but Casacalvo, the Commissioner sent by Spain to assist him, "a man of no ability," says Marigny, was anxious to return to his family and interests in Cuba, and hastened the preparations.

At both ceremonies of cession, Marigny, at Laussat's request, acted as his aide-de-camp; but ardently American in sympathy, as soon as Louisiana was given over to Claiborne, he volunteered on the staff of General Wilkinson. He remained in active service until 1808 when, on account of the fatal jllness of his wife, he sent in his resignation. Her death, he says, "closing the political career that might have been his." Nevertheless, with confident intrepidity, he afterward entered into politics, embracing the principles of the Democratic Party, of which he remained a faithful partisan through life. At the time of his death, it was said that for fifty years no Democratic mass meeting was held to be complete that was not presided over by Bernard Marigny. In 1804 he married Mary Ann Jones, daughter of Evan Jones, a wealthy Pennsylvanian, for a time American Consul in New Orleans, and of Marie Verret, of a fine old Creole family.

Mary Ann Jones died in Philadelphia, June 4th, 1808; her body was transferred to New Orleans, August 4th, 1808. She was interred in a new sepulchre, built by her husband, in a corner of the 
garden on his plantation, the lot and tomb having been previously blessed by the reverend Father Antonio de Sedella.

$\mathrm{By}$ this union were born two children:

Gustave Adolphe, born in 1808, was killed in a duel and left no issue.

Prosper François de Marigny, who died in Natchez in 1836. He married his cousin, Marie Celeste d'Estrehan. (His widow remarried Mr. Alexander Grailhe, a barrister.) They left two children:

Gustave Philippe, who married Elmina Bienvenu; and Marie Odile, married Alphonse Miltenberger.

About 1809 or 1810, he remarried Anne Mathilde Morales, daughter of Don Ventura Morales, former Spanish Intendant and Royal Contador, unenviably known to history for his intrigues against the American Domination, until Governor Claibarne forced his retirement from the city and States.

His courtship of Anna Mathilde Morales is thus related by one who heard the original account of it:

Arriving in Pensacola, Marigny went to a ball where his attention was soon attracted to the most beautiful woman in it. $\mathrm{He}$ expressed his admiration and asked her name. His informant thought proper to warn him: "You will meet trouble." "That's what I like!" answered Marigny lightly, and at once engaged the young lady to dance, and made himself agreeable to her the rest of the evening, to the exclusion of her other admirers.

The next morning he received seven challenges. "I cannot fight all at once," he answered, "but I will meet one every morning before breakfast, until all are satisfied." His first opponent fell with a sword thrust through the body. The other six professed themselves satisfied and made their apologies: "We see that you are a man of courage and honor." Marigny obtained without further opposition the hand of the beautiful young lady. 
Morales was reputed to have hogsheads filled with gold in his house; the hogsheads, as described, were found in his house-but they were not filled with gold!

In 1810 Marigny was elected to the Legislature. In 1812 he was elected a member of the first Constitutional Convention of Louisiana and, although the youngest of its members, he took no small part in framing the Constitution that ruled Louisiana for thirty-three years. He always fought frankly and squarely on the side of the Louisianians and against the increasingly aggressive partisanship of the Americans.

In this first Convention took place the historic effort by the Americans to change the name of the State to Jefferson. It was a proposition warranted to inflame the Creoles to the point of frenzy, and it did so. Marigny relates that one of the members, Louis de Blanc de St. Denis, declared that "if such a proposition had any chance of success, he would arm himself with a barrel of powder and blow up the Convention!"

In 1811, at what is still considered the most important marriage ceremony that ever took place in the city, when the Baron de Pontalba (the son of Marigny's godfather) was married to Micaela Almonaster, daughter of the Spanish Alfarez Real, the historic benefactor of New Orleans, Marigny, acting as the representative of Marshal Ney, the distinguished friend of the Pontalbas, gave the bride away.

A few years later de Pontalba proposed a more personal connection between his friend and the great Marshal. Among the papers found on Ney at the time of his arrest, was the following letter written by de Pontalba to Marigny: 


$$
\text { "PARIs, 11th July, } 1815 .
$$

"You know, my dear Cousin, the attachment that my son and I have felt for a long time for M. Maréchal Ney, Prince de la Moscou. Circumstances are sending him to New Orleans. He has chosen that part of the world from what I have told him of the liberty that one enjoys there and of the kindly and hospitable character of its inhabitants.

"Among them I have distinguished you, my friend, and it is to you that I am sending him, being confident that you will render him all the services in your power. See about an establishment for him according to the desires that he will communicate to you. Be assured that $I$ will be much more grateful to you for anything you can do for him than if you did it for myself. You will be the first person he will see on arriving. I have insisted he shall land at your home, because I know he will find there a good welcome and full liberty.

"When you know him you will see that he is the most modest and simple of men. If he sees that his presence is causing you any embarrassment or expense on his account, he will leave you to go to a tavern. Receive him then with the greatest simplicity; act as if he were not in your home. He will arrive in the sickly time in the city. I wish that you would obtain his consent to pass this time in the country. I am very certain that you will make the strongest insistence upon this, but I am afraid he will resist, if in a few days he sees that his presence is leading you into extraordinary expenses, as happened when upon my recommendation you received $M$. de Laussat so splendidly.

"In the meantime, my friend, and after he has become acquainted with the place, you will see about procuring for him a house, in the country near the city; I need not tell you how to go about this. I know you well and am very certain you will know how to meet all his desires. St. Avid will second you with all his power. You will not have forgotten that it was you who were charged by M. le Maréchal to represent him on the occasion of the marriage of my son . . ."

\section{"Pontalba."}

Archives Nationales.

Procédure de M. le Maréchal Ney.

de la premiére Div. Militre 
In another letter to his nephew St. Avid, Pontalba writes:

"I pray you my dear nephew to join Marigny in rendering to Maréchal Ney, Prince de la Moscou, all the services that you can."

Five months after these letters were written the Marshal was executed.

At this time, 1814-1815, Marigny was acting as Chairman of the Committee of Defense, charged by the Legislature to place the entire resources of the State at the disposition of General Jackson. He was one of the party of distinguished citizens who assembled to meet and welcome the General at his landing place on the Bayou St. Jean. Marigny thought that he should have had the honor of entertaining the great soldier during his stay in New Orleans.

"My name," he writes rather bitterly, "was not unknown to him; he had very recently been the guest of my father-in-law, M. Morales (in Pensacola), who made known to me the desire of the General to stay with me, and it would have been infinitely agreeable to receive him. . . ."

But a more pushing aspirant usurped what it almost seems was the right of a Marigny. Jackson arrived at Bayou St. Jean and the Mayor made his speech of welcome. It is worth while repeating what Marigny writes further about the reception:

"The rain was pouring down; all present were wet, muddy and uncomfortable; but the Mayor (given to singing madrigals to persons in power) assured the General that the sun is never shining more brilliantly than when you are among us!"

At the Battle of New Orleans, Marigny distinguished himself by his courage and activity. It is noteworthy that the glorious victory was reaped 
on the fields of the plantation of his Uncle de Lino de Chalmette.* In 1824 he supported General Jackson for President not only with his usual fiery eloquence, but also, perhaps more effectively, with force of arms. He was an ardent duelist and an expert with sword and pistol, and he has been credited with fifteen or more encounters.

His two duels in later years with Mr. Grailhe, the distinguished barrister, live with amusing distinctness in the memory of old friends of Marigny to-day. Grailhe married the widow of Marigny's son and made too free with her property. Bernard, the ever ready champion of the ladies, challenged him, and in the duel that followed shot or thrust Grailhe through the body, giving him a wound that resulted in a bend forward which made him walk, in local parlance, "doubled up." At his second duel with Grailhe, provoked by the same cause, Bernard told his seconds nonchalantly: "This time I shall try to straighten him." He shot or thrust him, in truth, in exactly the same place as before; and Grailhe did lose his bend forward, but gained a bend backward that made him even more conspicuous than before!

In 1825, when General Lafayette came to the United States and accepted the invitation of the people of Louisiana to visit their State, Marigny was selected to make the speech of welcome in French, and his family was the only private one that was

*Bernard Marigny's "Reflexions sur la Campagne du Général André Jackson en Louisiane," New Orleans, 1848, is the best account we have of the preparations made to meet the enemy before the battle; and of the ensuing episode.-Library of Lcuisiana Historical Society. 
visited by the General during the visit. Marigny says that he knew Lafayette well in France in 18221823, and that the General thanked him for having suggested that he visit the United States.

In 1827, when General Jackson paid his memorable social visit to New Orleans, accompanied by Mrs. Jackson, General Carroll and his wife, and General Houston, they all stayed with Bernard Marigny, who, as he says "was able to give them some pretty entertainments."

His second marriage not proving a happy one, he passed more and more of his time at his father's old summer home of Fontainebleau, on the northern shore of Lake Pontchartrain, not for the sake of the seclusion and quiet it offered after the excitement of American politics and financial speculations, but for the greater liberty it granted for the enjoyment of his favorite pleasures-the table and convivial intercourses with friends. Here it is that his standards of both enjoyments attained a height of perfection that has resulted in his gastronomic apotheosis in Louisiana's traditions and romance.

A more favorable spot for the pleasing of an epicure can hardly be imagined; a beautiful lake ever rippling under gentle breezes, or scintillating at the hour of dinner with the glitter of the setting sun; a white beach shaded by magnificent oaks, draped with hangings of moss; luxuriant flowers disposed like jewels on the green sward; hedges of Cherokee roses; vines of wild honeysuckle; the illimitable pine forest behind, fragrant and balmy, traversed by slowmeandering bayous; the forests teeming with game, the bayous and lake with fish. For service he had a retinue of accomplished, devoted slaves and a luxu- 
rious city was within easy reach to draw upon for wine. What could a crowned head ask for more?

He entertained at Fontainebleau with the exquisite generosity all his own, that allows no self-questionings save such as concern the comfort and pleasure of the guests. A paradise for an epicure and for Bernard de Marigny! It is not surprising that pleasure-loving friends from New Orleans flocked to Fontainebleau as pilgrims to a shrine; and with more confident assurance of the results than pious pilgrims ever enjoy.

There they found grassées that fed on magnolia berries; turkeys fattened on pecans; papabotse and snipe kept until they ripened and fell from their hangings; terrapin from his own pens; soft-shell crabs from the beach; oysters fresh from his own reefs; green trout and perch from the bayous; sheepheads and croakers from the lake; pompano, red fish, snappers from the Gulf; vegetables from his own garden; cress from his own sparkling forest spring; fruit from his orchard; eggs, chickens, capons from his own fowl yard. These, with sherry, madeira, champagne, and liqueurs, were the crude elements of repasts that he combined into ménus that Brillat Savarin would have been glad to have composed.

It is not surprising that the little town of Mandeville is as redolent of good cooking as some other little towns elsewhere are of religion and piety, for Fontainebleau had begotten the most beautiful, most charming, picturesque little lake shore town without doubt in the United States. The weary citizen of New Orleans can still find there seclusion, cool breezes, green shade of century-old oaks draped with moss, a lovely view, and liberty of enjoyment, 
in the good cooking as not the least of its attractions.

The boon of this unique and precious little town, the State, or rather the city, owes to Bernard de Marigny.

He it was who, during the early years of the century, conceived the idea of purchasing land along the lake shore and forest adjoining Fontainebleau until sufficient had been acquired for his purpose. He was inspired to make a town as poets are inspired to make a poem. He gave himself over, as a poet should, to his muse, and she, as a muse should, confided herself to him. Nature and art lent themselves kindly to the enterprise. Streets were made, trees were planted, lots were placed on sale, with an eye fixed rather to avoid undesirable additions to the community, than to secure financial profits. Public buildings were provided for, bridges built, a church and a market hall duly erected. Above all, a town government was instituted that eliminated, as far as mere human supervision could, the corrupting influence of American elections. In short, such as the little French town is to-day refined, elegant, yet simple-it left Bernard de Marigny's hand in 1830.

His congenial friend John Davis, an émigré from St. Domingo, and known to all as the famous impresario of what is always called the "celebrated Orleans Theatre," was associated with him in the Mandeville enterprise which included the employment of a steamboat to make the daily trip from New Orleans to Mandeville. Davis is also thanked (at Mandeville) for bringing thither the renowned cook, Louis Boudro, from Paris (with the other artists, lyric and dramatic, engaged for his theatre). Other cele- 
brated chefs followed Boudro in the course of years and by way of insuring the perpetuity of the town's culinary celebrity, they became in time the hotel keepers of Mandeville.

Marigny's continual financial extravagance, however, and the depreciation of his city property, produced their inevitable results. The clouds that later darkened his life began to gather, but it is to this period of his life that belongs the most famous adventure in it - the one that is always remembered first in New Orleans when his name is mentioned.

In 1820, when his own fortunes were ebbing, those of his father's old guest and friend, the Duke of Orleans, reached their flux with his ascension to the throne of France as King Louis Philippe I. He promptly showed his recollection of past favors by sending to his New Orleans friend; de Marigny, with whom he had kept up a faithful correspondence, the conventional French royal token of appreciationa beautiful dinner service of silver, each article bearing a portrait of the royal family. In a cordial letter (which is still in existence) the King invited Bernard to pay him a visit. This was not to be declined and Marigny, with his young son, called "Mandeville," went forthwith to Paris and to the Tuilleries. They were received in the palace with open arms according to their highest expectations. They were presented to the Royal family and given seats at the family table. In fact, the Creole hospitality of yore was returned with Creole cordiality. Bernard, after six months of the King's hospitality and Court life, made his reappearance in New Orleans, perhaps with the satirical smile that usually accompanies the narrative as told by his friends. The King had 
returned to the son every obligation he owed to Philippe de Marigny, save the one debt of honorthe princely sum of money that had been loaned to him!

But with paternal friendship, he offered to provide for the future of young Mandeville by placing him, for military education, in the Academy of St. Cyr, which assured him an officer's rank in the French Army. The offer was sccepted. Mandeville was sent to the Academy and in a few years gained his rank as lieutenant in a cavalry corps of the élite. All should have gone well with him but, according to the chronicler, ${ }^{*}$ who seems to speak from personal knowledge, the young Creole, accustomed to the activity and rough exercises of hunting and fishing in Louisiana, soon tired of the monotonous military life in France during a peace, ruffled only by an acrimonious feeling against the American Republic which expressed itself in uncomplimentary remarks in public places. He became involved in a duel on this account, which necessitated his retirement from the army and his return to his own country where he was received with acclamation as a hero. With the exception of his father he was the handsomest man in the city; the most gallant "beau" in society. A perfect cavalier, he had brought with him from France the beautiful charger presented to him by the King, upon which he was fond of displaying himself. His father, who prided himself also on his horsemanship, was wont to look upon his son's equestrian feats with a cold eye. One day, after a brilliant exhibition by Mandeville, Bernard remarked coldly that he could do the same.

*Castellano's "New Orleans As It Was." 
Mandeville instantly dismounted and, with a low bow, handed the reins to his father with a courtly "Montez, mon père." No sooner said than done.

But Bernard had not seated himself in the saddle before the horse promptly threw him to the ground.

Bernard never forgave his son the "trick," as he considered it.

Mandeville married Sophronia, daughter of Governor Claiborne. He entered the Confederate Army as Colonel of the Tenth Louisiana Volunteers and served in Virginia. The Confederate Government, however, recognizing his high military fitness, assigned him South to organize a force of cavalry.

He survived his father and, through a long life of poverty, maintained an unimpeachable reputation as a man of courage and honor.

This adventure or experiment over, Marigny fared on through middle age, as he had through youth, shrugging his shoulders at ill fortune and not troubling his digestion about what might betide him or those who came after him. His separation from his wife became permanent; his daughters married; his sons, smaller than he,went their smaller way.

Marigny was re-elected to the House or Senate successively until 1838 . The truth of what he said of himself in a political pamphlet, printed in Paris as early as 1822, has never been contested, and is borne out by the rest of his political career:

"Ten years of my life have been sacrificed to public affairs; and no one doubts that this has cost me considerable expenditures. These expenditures I have borne, for I have never solicited or obtained a lucrative office. I have contributed my efforts that my compatriots should not be entirely dispossessed of their language, 


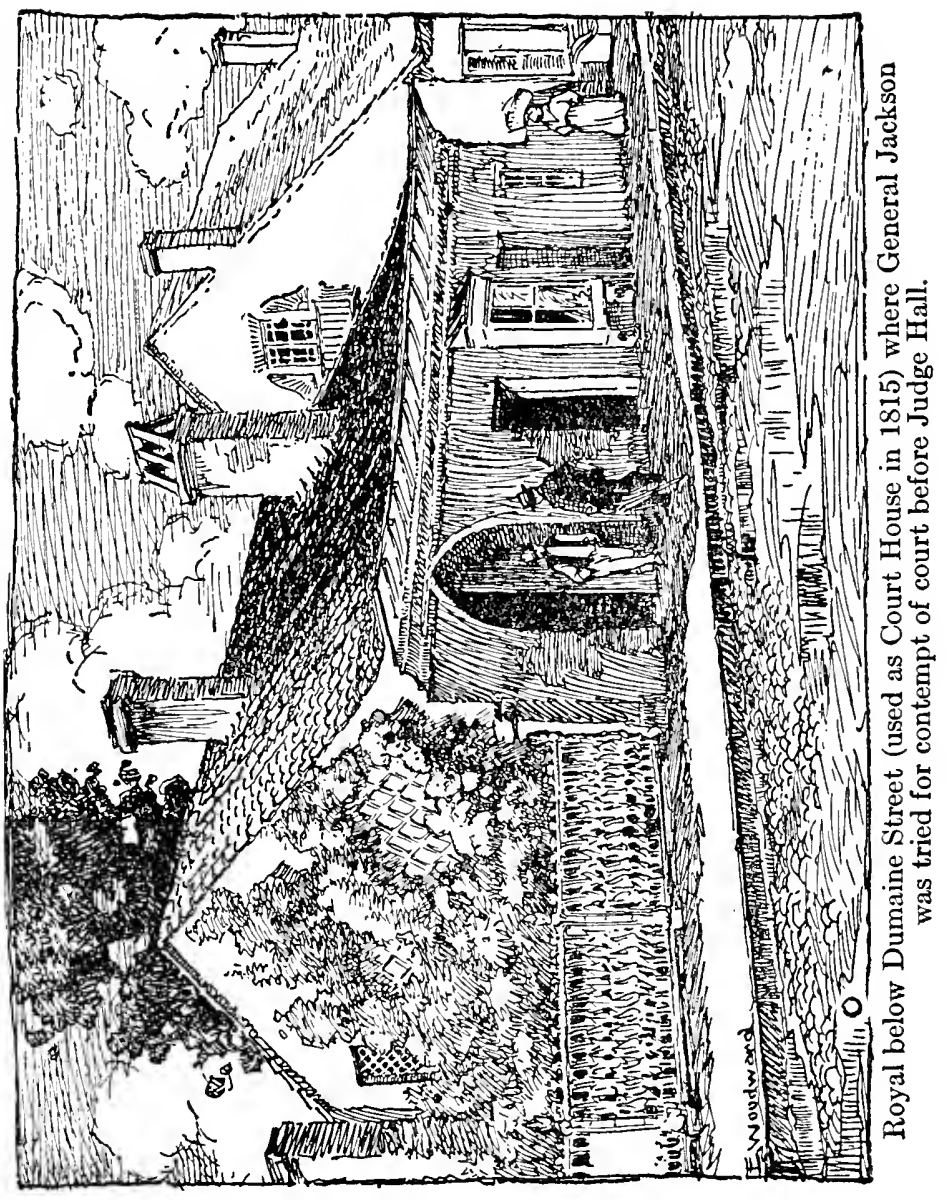




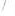


their customs, their laws. I possessed an immense fortune, whereas now it barely amounts to the value of one of the four inheritances that I successively received; and I think I may claim that the use I made of them has always been honorable, by my household standards as well as by the assistance I have been able to give to the needy; to the poor mother of an indigent family, and to unfortunate strangers. Have they not always found me willing to tender a helping hand?"*

The allusion to his waning fortune is to be explained by other reasons than those mentioned. The natural antagonism between the American and Louisianian citizens of New Orleans developed into the fierce rivalry of business competition between the American quarter (the Faubourg St. Mary) and the Creole quarter (the Faubourg Marigny); between the "uptown" and the "downtown" ideal of progressiveness. It was a purely financial struggle. Marigny, as the most prominent among the Creoles and the largest landowner in the city, was the natural leader of the Creoles; but he and they, with their antiquated principles, were as children before the keen-witted Americans-trained to perfection in the skilled manipulation of municipal patronage for private profit.

In the fight New Orleans was rent into three distinct parts or municipalities, each one with its own Board of Aldermen, but all under one Mayor and Council. Marigny protested with might and main against this rendition of Solomon's judgment. What he foresaw, happened; the Faubourg St. Mary became, as he called it, "the spoiled child of the Mayor and Council, the object of their tender affection,"

* This statement is borne out in every particular by Bernard Marigny's constituents. He was, according to their belief, the most generous and charitable, as well as honorable of men. 
and grew with amazing rapidity into the beauty and prosperity of an enterprising American city, pulsing with Western blood and energy; while the Faubourg Marigny, motionless and inert, still lay, like a sleepy bayou, on its own outskirts.

The motive power of the development in the American quarter was supplied by the genius of two men, great in the history of New Orleans: an American, Samuel Jarvis Peters, and an Englishman, James H. Caldwell. They introduced gas and waterworks, paved the streets and built hotels in the American city, and improved its quays along which the flatboats from the West, gorged with produce, tied up three deep to unload their rich cargoes into vast warehouses."

We are told by an American narrator that Peters, who lived in the vieux carré with his auxiliary and co-worker, Caldwell, had originally selected the Creole Faubourg as the field for their civic improvements, but it happened that the old Faubourg was virtually owned by that proud Creole princeling, Bernard de Marigny. Being informed of the plans to beautify his domains by the building of a firstclass hotel, a large theatre and the laying out of handsome paved streets as well as warehouses, cotton-presses, gas and waterwork plants, etc., to make it a commercial and social center, Monsieur de Marigny finally consented to dispose of his vast estates for a fabulous price. The act of sale was finally drawn up, but when purchasers and vendor met on the appointed day in the notary's

* "Autobiography of Samuel Jarvis Peters, by George C. H. Kernion." Publications of Louisiana Historical Society. Vol. VII, 1913-14. 
office to sign the deed of transfer, Madame de Marigny failed to put in an appearance, and as her signature was necessary, on account of certain rights she possessed in the property about to be sold, the deal could not be consummated without her. Trembling with rage at this unexpected and, as he believed, premeditated disappointment, $\mathrm{Mr}$. Peters, after soundly berating Monsieur de Marigny for his breach of agreement, finally exclaimed: "I shall live, by God, to see the day when rank grass shall choke up the gutters of your old 'Faubourg'!" His prophecy was, unfortunately, ultimately fulfilled.

Marigny's rapier did not leap from its scabbard, as might have been expected; for in another version of the affair that comes down to us, he had upon reflection decided, with characteristic arrogance and obstinacy, to build up his own Faubourg himself, and make a Creole city of it that would outshine forever the American one. He would suffer no usurpation of American "genius" in his own municipality, and thus the refusal of his wife to sign the deed gave color to Peter's suspicion that it was a ruse of Marigny's own invention. A suit filed shortly afterwards, however, by his wife for the restitution of her paraphernal rights, exonerates him from the suspicion of bad faith, and gives as the reason why Madame de Marigny did not sign the deed that she wished to protect her own rights.

Marigny made an attempt to fulfil his ambitious schemes. The great Marigny property was cut into streets to which he himself gave the pretty names Poet, Love, Good Children, Port, Moreau, Piety (but the original of this was a friend, Piété), Enghien, Craps (from the game of cards to which he was 
addicted), Bagatelle, Désiré. The pretty names are all that survive of his scheme; which his evil fortunes, and not his will, prevented his carrying to a success.

The losing of this golden opportunity brought him almost to the verge of unpopularity with his fellow Creoles. Although he had served his party well and had been sent to the State Legislature in 1817, acting there as President of the Senate, he was, unfortunately, not elected when he was nominated as candidate for the position of Governor of the State. "A Creole for Governor!" had been his slogan in every gubernatorial contest. He claimed that it was owing to him that Villere was elected to succeed Claiborne, and added with caustic wit, when Robertson succeeded Villeré, "He will be succeeded by Mr. Johnson" (as he was) "and Virginia will be exhausted before another Louisianian is made Governor in his country."

His last public service to Louisiana was in the Constitutional Convention of 1845 , when, as he says, he defended the great Democratic principles of universal suffrage and free public education, and when also, he made his speech in defense of Pierre Soule, that contains the ever-memorable rebuke to Judah P. Benjamin which sounded the death knell of American exclusiveness in Louisiana. No politician has since then reopened the question that Marigny settled forever.

"Sir," he addressed Mr. Benjamin, "contrary to all parliamentary usage you call upon the other distinguished member from New Orleans, Mr. Soule, and ask him, 'Sir, suppose you had been placed at the head of an army to meet in deadly combat your own countrymen. Could you, would you have done so?' Sir, I tell you that 
you have inflicted upon him an unjust provocation; and I give you distinctly to understand that I take up the glove in his behalf; and Sir, I trust that you will not complain of my not being a native of the country, since I descend from those ancient warriors who conquered the country, and here represent six generations of Louisianians.

"Fortunately for me, all your fine quotations are lost upon me. I never read any of those works which are supposed to make a logical man. But, Mr. President, I am one of those who, looking at things as they are, feel myself able to meet the emergency of the hour, and to accord my political acts to the political needs of my country. But, Sir, I ask you by what right do you expect to disfranchise in 1845 those who have rights guaranteed them in 1812? Sir, I tell you, I, Bernard Marigny, tell you that you are, after all, nothing but the servant of the people-nothing more, nothing less; presume upon your authority, and they will soon bring you to a just appreciation of their power over you, and it would not at all surprise me, if they were to obstinately persist at the very next election in selecting a Governor from the very men whom you are now so anxious to exclude. The laws of the country recognize no distinction between one class of citizens and another. Is there any principle of free government, any principle of republicanism, to sanction such a pretension? They say that a naturalized citizen is not to be entrusted with the power we confer upon our Governor. What, Sir, is the power of that Governor, compared with the power we are administering now?" *

W. H. Sparks, who served with Marigny in the Legislature, says that his wit and satire were his most dreaded weapons, and ridicule was his forte. Mr. Sparks gives the following incident:

At the end of the heated debate on the question of cutting New Orleans into three municipalities, during which Marigny had exerted himself to the utmost to protect the city and himself against the disaster, as he saw it, Marigny was observed passing around among his friends a squib containing the following lines:

"Sparks and Thomas Green Davidson,

Rascals by nature and profession."

* De Bow's Review, 1846. 
A day or two later Sparks read to a group of his friends his quite sufficient retort. It begins: "Dear Marigny," but concludes with:

"A warmer heart or weaker head, On earth, I own, I never met.

And on your tomb inscribed shall be

In letters of your favorite brass 'Here lies, O Lord! we grieve to see

A man in form, in head an ass!" "

Marigny heard the reading, arched his brows and, without speaking, retired. An hour later he came to Sparks and said: "Suppose you write no more poetry? I shall stop. You can call me a villain, a knave, a great rascal, every great man has had that said about him. Mr. Clay, Mr. Webster, General Jackson, all have been called so. You can say that; but I tell you, Sir, I do not like to be called an ass!"

"He was the aggressor," continued Sparks, "and though offended, was too chivalrous to quarrel. He had fought nineteen duels and I did not want to quarrel either."

The last remnants of the great riches that Marigny inherited were lost by him. In scriptural language, his fortune took wings and flew away, as fortunes always do; unless, as Marigny says of certain rich men of his day who kept their wealth, "they were born dead, since they never knew how to live."

When he was nearing seventy years of age, he wrote in self-defense against the sneering accusation of poverty and printed a pamphlet for private circulation : $\dagger$

"To my fellow citizens:

"The calumnies," he says, "of which I have been the object for

" "The Memories of Fifty Years."-W. H. Sparks, 1870.

$\dagger$ "Bernard Marigny's a ses Concitoyens." New Orleans, 1853. Pamphlet in T. P. Thompson Collection. 
some time, the epithet of 'old fogy,' thrown at me by certain individuals, force me to give to the public the following facts."

$\mathrm{He}$ enumerates his services to the State in a very modest and moderate vein, and then follows his private explanation; a story of financial loss and failure, only too well known in Louisiana; a road to failure well trodden by sugar planters in the past.

"Certain persons," he writes, "have often asked the question: 'How did Mr. Marigny lose the fortune he possessed, of five or six hundred thousand dollars?' The answer to the question is as easy to make as to understand-it disappeared under the influence of events and circumstances which I could not control. In 1839, Messrs." (he names five gentlemen) "undertook the estimation of the value of my possessions, an estimation I judged necessary at the time of my departure for France. The amount of my fortune was fixed by these gentlemen at nine hundred and fifteen thousand dollars. My debts then amounted to three hundred and twenty thousand dollars, two hundred and eighty thousand of which represented a debt to the Citizens Bank. I rallied my resources and asked for longer terms from my creditors, for I thought I could re-establish my fortune. I had a sugar plantation and a brickyard, but to develop the sugar plantation I needed to construct buildings, dig canals, provide equipments, and put in necessary machinery. To meet such great expenses, crops were needed. They failed in consequence of a crevasse in 1850 , followed by another in 1851. That is not all: bricks fell to their lowest price" (he owned a large brickyard which he worked with his slaves,) "and the price of sugar* was reduced from two and a half to three cents the pound.

"On this the Citizens Bank announced to me that if I did not decide to sell the plantation, they would seize it. I was, therefore, forced to sell at a very moderate price. The Citizens Bank, naturally

*A cause of the financial distress in Louisiana was the tariff which had depreciated the value of American sugar in proportion as the duty had been reduced on the foreign article. In 1837, one hundred and thirty-six sugar plantations were given up; numerous bankruptcies followed. Lands could no longer be sold; fortunes based on them fell even more suddenly than they had risen.-Annals of Louisiana. 
took possession of all the products of the sugar house and of the brickyard.

"Calculating upon a fine crop in 1851, which I could have made if it had not been for the crevasse, counting also upon an office (that of Mortgage and Conveyance), whose commission did not expire until February 10th, 1855, I had contracted a debt of eight thousand dollars in order to put my sugar house in a condition to work profitably. But my hope was disappointed.

"In 1851 the crops failed. There remains to me, therefore, to-day only my office, which, as I have explained, expires in 1855. I have still a few slaves, but their value is partly covered by the (paraphernal) rights of Madame de Marigny, and the returns from their hire pays the taxes and expenses of her house. As for my other property, it barely covers what is owing to the Citizens Bank."

The site of the great Marigny canal on Champs Elysées, which in colonial days had fed a sawmill that poured gold into Pierre Philippe's coffers, was bought by the Pontchartrain Railroad. Fontainebleau went from Marigny and all his land in Mandeville, with the exception of one small house, which still enjoys local fame as the last residence of the whilom Lord of all Mandeville, to which he would still come from New Orleans seeking recreation and refreshment.

Estrangement from his wife was followed by estrangement from his children and grandchildren; the friends of his convivial days declined with his fortunes. He retired to an apartment in one of the houses which he could still claim as his own (Frenchman Street, near Royal, still standing), a plain threestory brick building kept by a colored housekeeper. And here, in sight of the great mansion of Pierre Philippe de Marigny, his father, where he was born, and where took place the great and stately entertainments that made the name of Marigny famous in the past, in two rooms furnished with remnants of his 
old furniture, the portraits of his ancestors on the wall; on the sideboard, the silver service presented by Louis Philippe, afterwards sold to the mint by weight, he passed his days like some old sailing vessel, its stormy voyages over, safe in the harbor. In this seclusion he penned his pamphlet, "Bernard Marigny a ses Concitoyens," in 1853. It concludes with the lines:

"Nearly seventy years old, with no fortune whatever, I ignore the destiny that awaits me. However painful it may be, I will support it with calm and resignation."

\section{In a postscript he adds:}

"Believing it to be my duty, before descending into the tomb, to make known the results of more than forty years of minute research into the history of my country, I announce to my readers that I am at present writing a work, already well advanced toward completion. Its title will be 'Reflections upon the History of Louisiana, under France, Spain and the American Government.'"

The work did not advance beyond a sketch, which was published in pamphlet form in 1854 . It bears the following dedication:

"To the Honorable Members of the General Assembly of Louisiana.

"Gentlemen:

"Unforseen vicissitudes having deprived me of a considerable fortune, I have been compelled to abandon the political career which had been to me peculiarly attractive. Consigned to an office (mortgage and conveyance) where my duties require my presence, I have devoted a few hours of my leisure to a work which, I trust, will at least show my attachment to my native land of Louisiana, as well as my devotion to the United States of America. This work is dedicated to the General Assembly of Louisiana. Be pleased, gentlemen, to accept it as a humble pledge of my patriotism.

"I remain with respect,

"Your obt. servt.,

"Bernard Marigny." 
It closes with words that cannot fail to touch the hearts of a Louisianian, or indeed of any lover of a "good sport" of the old-fashioned kind.

"Having nearly attained the age of seventy, having lost my fortune and independence, it is an arduous task which I undertake. Reader, I solicit in advance your indulgence in view of the motives which renovate my strength and make me almost forget my troubles. I venture to hope that Providence will aid me, and that my moral energies will not be wanting. I also hope, my beloved countrymen, that you will say at some future day: 'We have read the work of old Bernard Marigny-we have recognized therein his patriotism.' To noble hearts the native land is ever dear!"

This tender commitment of his work to posterity stays the hand of a Louisiana critic, which would not if it could dissect it coldly, any more than it would use the scalpel upon the body of an ancestor.

A prettier historical legacy than "old Bernard Marigny's" to his countrymen has rarely been made. Well may Alcée Fortier declare that it was received with almost filial respect."

Beginning with the Treaty of Aix-la-Chapelle, 1748 , he explains, in his shrewd personal way, the causes of the American Revolution, and the subsequent political evolution of the United States, its growth in power and in moral influence. He urges the annexation of Cuba, for reasons contained in his statistical study of the island. Strange to say, as Fortier remarks, although writing only seven years before the Civil War, for all his political wisdom, he did not foresee the bloody chasm that lay across the path of his country. He was confident, he says, that the compromise of 1850 had allayed the passions of the United States.

*Louisiana Studies. 1894. 
In his relation of Louisiana history, he "drank of the brook in his way," and he passes the refreshing draught on to his readers. The faded documents in the archives of the Louisiana Historical Society, that historical students study to-day, he knew practically in their living form. From Bienville to Aubry, from Ulloa to the old and infirm Salcedo and Casacalvo, "the man of no ability," he knew every man of importance, either from his own personal intercourse with them, or as they lived in the memory of his father or of his father's father.

The preliminaries of the cession of Louisiana was fresh in the minds of men whom he knew in France and New Orleans. He was a familiar of Laussat; Lafayette was an old friend, and so were Jackson and Henry Clay and Sam Houston.

Marigny relates among other personal reminiscences, a conversation held with Louis Philippe in 1837, when the King, addressing him as "mon cher Bernard," asked his opinion about the political condition of Texas, and whether the new republic would be able to withstand the army of Mexico. Marigny responded that the King, who had traveled all through the United States and knew its power and population, was well able to answer his own question; but he gave his reasons for believing in the future of Texas as a member of the Union. The King listened attentively and observed to him: "What you say is very reasonable." The Republic of Texas was shortly afterwards recognized.

"Louis Philippe," comments Marigny, "was a wise and enlightened King. I have seen but few men who entertained a greater admiration for our institutions and high opinionare of the American 
people. Louis was really a man, under the garb of royalty; he was a republican King."

The Louisiana Assembly passed a vote accepting his historical sketch, and ordered one thousand copies printed; five hundred in English and five hundred in French, for which M. de Marigny was to be paid one dollar apiece.

Marigny lost his office in 1855, and thenceforth lived on the crumbs of his former possessions, selling here and there small pieces of property that had lain, as it were, unnoticed at his feet. Having lost all, he had nothing more to lose in the Civil War. In his humble home he escaped the rude hand of the Military Governor of the city that fell so heavily upon his descendants, and the descendants of his friends and the relatives about him. He has left no record of himself during these hard years of the war, nor of the harder ones of reconstruction that followed the war. The breaking up of old ties; the inroad of strange men and strange measures; the wrecking of old estates and of hopes, old and new, left him apparently, for once in his life, speechless.

He passed his evenings in the congenial circle of the family of the son of his old friend, Governor Claiborne, where he devoted himself, as he had devoted himself through life, to the ladies; amusing them with his good stories, his wit and his puns. Occasionally he recited for them, in the fine manner learned in France from Talma, in his youthful days, always choosing some beautiful lady to address as queen. Never sad, never complaining, ever the polished, courteous, dignified old French nobleman of the old régime, who for all his gay wit and persiflage was never known to speak lightly of religion, or its sacred 
practices. He dressed as simply as any citizen of moderate means, but he always wore broad silver buckles on his shoes.

The handsome residence of the Claibornes faced Washington Square, the ground which Marigny had presented to the city; its lower boundary was the Champs Elysées, named so fancifully by him in the days when his ideas were fanciful and poetical. After his evening visit, accompanied always by the young son of the Claiborne family (now Judge Charles F. Claiborne), he would skirt Washington Square and cross the Champs Elysées and wend his way a block further on to his home on Frenchman Street, talking to his youthful friend of his old days and sowing many a good story in the fertile, appreciative mind. Always lively and interesting, he never let fall, however, a word or hint relating to his writings or to any serious preoccupation.

Of a morning or afternoon, he loved to saunter up Royal, Chartres, or Bourbon Streets, which held the houses so full of gayety and pleasure to him in the past, and which must have lain in his memory, like some fine opera; with beautiful scenery, gallant actions, charming actresses, lovely figurines, fascinating dancers.

In old days he always rode in a carriage, now he went on foot, sometimes essaying an omnibus. It is related that he never found an omnibus driver who would accept fare from him. "No! No! M. de Marigny, not from you!"

In passing a house, if he heard a piece of music beautifully played on the piano inside (one heard such playing then oftener than to-day) he would stop and listen. Music held him in bonclage in old age as 
in youth. Then, mounting the little wooden steps, he would knock on the door or ring. When the servant opened the door: "Say it is M. de Marigny." $\mathrm{He}$ would enter without ceremony and sit in a chair, making a sign to the pianist to continue, which she was glad to do. M. de Marigny! Whom would any woman rather play to?

Men would stop on the streets to look at him; "old Bernard Marigny!" a relic of Colonial Days, walking the streets, at ninety! Handsome, active, erect, with intellect clear and vigorous, manners courtly; the hero who, in current parlance, could throw away thirty thousand dollars on a bagatelle, but who would never consent to bring a lawsuit against a fellow citizen.

So, on the 4th of February, 1868, in his usual gayety and friendliness, on his daily promenade, greeting those who saluted him with kindly cordiality, his foot tripped on the pavement. $\mathrm{He}$ stumbled and fell heavily, striking his head. Death ensued almost instantly.

His body was conveyed to his apartment on Frenchman Street and there, in the habiliments for the grave, Bernard de Marigny was laid underneath the portraits of his family and his royal friends. "It was impossible," writes the reporter who chronicled the event for a daily paper, "to gaze unmoved upon the aged form, the last of the Creole landed aristocracy, the representative of the strength, the follies and wealth of a passed generation, one who knew how to dispose of a great fortune with contemptuous indifference."

In cold, inclement weather, next day, the funeral took place. An extended line of carriages headed 
the long and imposing procession which, passing Washington Square, slowly proceeded up Royal Street. It stopped not at the Cathedral, as expected, but went out to the old St. Louis Cemetery to which the tomb of his first wife had been transferred.

People on the sidewalk looked with solemnity upon the hearse that carried him who for seventyfive years had represented without a rival the life, gayety, wit, polish, refinement and luxuriance of society; who, for all his wealth in youth, died poor yet left behind him nothing to put a stain upon his proud escutcheon!

He once wrote an epitaph to be placed on his tomb and confided it to a friend, but when the time came to use it, the friend could not find it. He could only remember that it was well written and characterized by originality, simplicity and wit; not ostentatious nor self-flattering. The epitaph was never found, nor the other valuable relics and papers left by him.

His will, dated July 8th, 1865, contained the following requests:

"I ask that my body shall be placed in the tomb of my first wife, in the old cemetery facing the Carondelet basin; that a tomb with two compartments be made there of brick, plastered with cement.

"My grandson, Gustave de Marigny, is the head of my family, being the son of Prosper de Marigny, by my first marriage with Maria Jones. My testamentary executor will remit to him my family portraits, the engravings representing the Orleans family, all my family papers, the letters of my ancestors, and correspondence, particularly with the Duke of Orleans, who became King Louis Philippe, and the letters of that King."

By his union with Mathilde Morales, Marigny had five children: 
*(1) Antoine James (known as "Mandeville" Marigny; born 1811, died 1890. He married Miss Sophronia Claiborne, daughter of Charles Cole Claiborne, first American Governor of Louisiana. She died in 1890. The three children born to them died without issue.

(2) Rosa de Marigny; born 1813, married to M. de Sentmanat, of Mexican fame. They had three daughters; one married Nelvil Soulé, son of Pierre Soule; the other married Allain Eustis (descendants living in Europe); and the third married Philippe Villeré, no issue. Rosa de Marigny remarried, in 1832, Enould de Livaudais; no issue by this marriage.

(3) Angela de Marigny; born 1817, married Mr. F. Peschier, Swiss consul in New Orleans. They had several children; one of the daughters married Leon Joubert de Villemarest of New Orleans.

(4) Armand de Marigny.

(5) Mathilde de Marigny; born 1820, married Albin Michel de Grilleaud, son of the French consul of that name in Louisiana. Descendants are living in Europe, where they still enjoy the highest social preëminence.

By the death of Prosper de Marigny, great-grandson of Bernard de Marigny and Mary Jones, his first wife, in Mandeville, 1910, the name of Marigny became extinct in Louisiana, where it had held sway for over two hundred years.

*Biographical and Genealogical Notes concerning the family of Philippe de Mandeville, Ecuyer Sieur de Marigny, 1709-1910. J. W. Cruzat. Louisiana Historical Society Publications, Vol. V. 


\section{CHAPTER IV}

\section{BAYOU ST. JEAN-THE DREUX FAMILY}

T $\mathrm{T}$ may be remembered that on Iberville's first 1 reconnoissance of the Mississippi River in 1699, he stopped at a landing recommended by his Indian guides and was conducted over a short path to a little bayou which floated their pirogues to the lake, where, in truth, Iberville could see his ships in the distance. This incident decided the site of the future city on the Mississippi, the guiding star of Iberville and, later, of Bienville's ambitions.

Bienville in course of time adopted this shorter route from the lakes to the river, in preference to the longer and somewhat dangerous journey through the mouth of the river. From his name, Jean, the useful little bayou received its name of St. Jean, and when the city was founded some years later, it was by this back door, as it were, that new arrivals entered it.

This was the road that Le Page Du Pratz was advised by Bienville to take when he came to locate his concession for a farm. His ship anchored at Dauphin Island, ${ }^{*}$ and he says that as soon as the Te Deum had been sung, in thankfulness for the safe voyage, the passengers and their effects were landed. In a few days he found means of transportation and hastened the departure of his party "with as much joy as diligence."

* "Sieur de Bienville." Grace King. 
His boat followed the gently curving line of the Gulf Coast, passing Pascagoula, Biloxi, Bay St. Louis, leaving Horn Island, Ship Island and Cat Island behind them on the left-the usual and always beautiful itinerary of the summer yacht. Going through the Rigolets, camping en passant on the Isle à Coquilles, he entered Lake Pontchartrain. Pointe aux Herbes and Bayou St. Jean dropped behind them; Bayou Schoupique, which was guarded by a fort, received them. The boats ascended until they came to an old village of the Colapisas, "the nation of those who see and hear," where they found Jean Lavigne, a Canadian, established. Dupratz sought the location he desired; not there, however, but on the Bayou St. Jean, a half league from the capital.

The Bayou St. Jean offers the visitor to-day the same attractions that induced Le Page Dupratz to stop on its banks, with the soft placid aspects of its shores; the easy, somnolent serenity of its tranquil waters, too tranquil to show a current; the drooping willows hanging over it; the sturdy oaks standing on the high land behind them. The scenery woos the eye and speaks to the heart to-day, as it did then; and, as in Dupratz's time, it charms home seekers into preferring its beauty to a more profitable venture financially in the city. The sky may not be bluer overhead there, foliage may not be greener, flowers not bloom more spontaneously-but they seem so to the denizen of New Orleans, who loves to leave the streets and their car lines behind him, and wander along its quaint, pleasant paths.

The concessionaires on Bayou St. Jean throve from the very beginning, and became noted as much for 
their wealth as for their air of aristocratic supremacy. Their houses were the first to show a pleasing deviation from the absolutely plain structures in the city. They were built with two stories, and of brick laid between heavy posts, "briquetté entre poteau," as it was called then.

By the end of the century, visitors were taken out on the Bayou St. Jean Road, to see the handsome villas there and their gardens. During the summer citizens were wont to go there for fresh air and bathing-incredible as it may seem to-day. Tradition says that the waters were then clear and limpid, showing a firm white sand bottom; the bottom of the bayou is now soft mud, the stagnant waters are dark and have an evil repute for producing malarial fever.

In the Census of 1726, Bayou St. Jean is mentioned as an "embarkation to reach Biloxi, Pascagoula and Mobile." It numbered of masters 23, servants 6 , slaves 10 , horses 6 , cultivated tracts 154 . The neighboring village, Gentilly, settled at the same time, had gone far ahead in its prosperity. It numbered of masters 21 , servants 50 , slaves 40 , horned cattle 139, horses 11, cultivated tracts 291 .

The authors of this prosperity, the "Sieurs de Gentilly," as they were called, were the locally celebrated brothers Mathurin and Pierre Dreux. Their names are seldom met separately. The record of the family, still carefully preserved, begins bravely with the name of the Comte de Dreux, fifth son of Louis VI of France (1108-1113) and quietly travels down across the names of Kings of France and Dukes of Brittany, through centuries, until it comes to the Marquis Dreux-Brezé, Grand Master of Ceremonies under Louis XVI, to whom was ad- 
dressed Mirabeau's thundering answer, "Go and tell your master that we are here by the will of the people, and will leave only by force of arms!"

The Louisiana branch of the family begins with Mathurin Dreux, born in 1698 at Savigny, Province of Anjou, France; son of Louis Dreux-Brezé and Françoise Harant. He emigrated to Louisiana in 1718 , during the period of inflation by the Company of the West. According to family tradition, he was one of the men who accompanied Bienville, when he actually landed on the site of New Orleans. It is said that he directed the clearing away of the forest and alignment of the streets; and that he signed the Procès Verbal, sent to France by Bienville.

Like other friends of Bienville, and like Bienville himself, he obtained, "in recognition of his services," according to the accepted formula, a large and valuable concession of land, to be located by himself.

He did not, however, follow Bienville's example and select a location for plantations, either above or below the future city. With a shrewder eye for business, he chose a tract richly wooded, lying along the Bayou St. Jean, and extending over a ridge that rose from the flat land and ran like a fortification across the rear of the city. It was the highest land in the region, well above the constant danger of overflow from the Mississippi or from the bayou when flooded by the waters from the lake; a tract of land that to this day maintains its reputation for beauty, salubrity and fertility. ${ }^{*}$

* Metairie Ridge, as it is known to-day, is the truck farmers' locality. A portion of it at present is Gentilly Terrace, the most beautiful of the suburbs of New Orleans. 
Here Mathurin Dreux was joined by his brother Pierre. The two became partners and engaged in the business of cutting timber, making bricks and raising cattle-enterprises that at that time offered a sure road to wealth. Their own forests furnished the timber, their soil the clay for bricks, their clearings the pasture for the cattle, and their slaves the labor needed.

The place was called Gentilly from home sentiment (Gentilly being a Commune in the Department of the Seine) and in a few years the brothers became known as the Sieurs de Gentilly, and are so designated in official documents.

In 1732, according to the Cathedral archives, "Mathurin Dreux, inhabitant of Gentilly, an officer of militia of this province, son of Louis Dreux, citizen of Savigny Anjou, and of demoiselle Françoise Harant, native of Savigny, diocese of Anjou, and demoiselle Claudine Françoise Hugot, daughter of the deceased 'garde magazin général of the concessions of Monseigneur LeBlanc' and of Françoise Martin, widow of Sieur Moriset," received the nuptial benediction in the Parish Church.

In the year following, 1733, Pierre Dreux, designated also as an officer of militia, was married to demoiselle Anne Corbin Bachemin, daughter of Jean Corbin and Anne Marie Judith le Hardy, natives of St. Malo, parish of St. Lawrence. Only the immediate relatives signed the record.

The two brothers occupied a joint home-a handsome house with spacious rooms and galleries, surrounded by gardens. It was for a century the show place of New Orleans, to which all strangers were conducted. Laussat, in 1800, writes that he was 
taken out on "Bayou Road, the fashionable drive of the city."

The further life of the two brothers follows the uneventful history of the happy and prosperous. living in a style of stately independence, and maintaining an attitude of aristocratic supremacy over what was virtually their seigneurie Gentilly, the large family did not apparently become involved in any of the political complications that troubled the serenity of life in New Orleans. Perier, Vaudreuil, Kerlerec, followed one after another in the government; the Natchez massacre, which, like an earthquake horror, shook the colony; the Chickasaw war, the retirement of Bienville to France-there is no trace of these events in the records of the family that have been preserved. Neither the heroic, daring revolution against the Spaniards nor the fighting of 1815 counted the name of Dreux in any of their gatherings and proceedings.

The name, in fact, is to be found only in the record of the marriages of the six children, and of their children into the great families of the province.

François, the eldest son, married a de Lorme.

Gentilly, a Bermudez.

Guy, a Beauregard, the great-aunt of General Toutant Beauregard. Guy's second wife was Félicité Trudeau de Longueuil.

Françoise Claudine, the eldest daughter, married the Chevalier Soniat du Fossat.

Jeanne married Robin de Logny.

Charlotte married Jean Gabriel de Fazende. Their daughter became the wife of Jacques Philippe Villeré, first Governor of Louisiana. On the death of Mathurin, in 1718, his extensive 
estate was divided among his children, and in the course of two generations the great fortune of the Dreux, like that of the Marigny and the Livaudais, became subdivided into insignificant fractions among their descendants.

Guy, the youngest son, was maintaining the brickyard in 1796, when de Pontalba, as he mentions in his letters to his wife, visited it and bought from Guy five thousand bricks, at eleven dollars per thousand. De Pontalba mentions the gay parties that used to make pleasure excursions to the Dreux plantation at Gentilly; and he always pauses, in his letters, to pay his compliments to the "Widow Guy Dreux," the most beautiful, charming and agreeable lady in the city. Before her marriage she was Félicité Trudeau de Longueuil.

The military spirit, however, of the descendants of "Louis the Fighter" was dormant only, not extinct, in the Louisiana branch. It awoke to glory and to fame in 1861, in the person of Charles Didier Dreux, the son of Guy Dreux and Léontine Arnoult, and grandson of Didier Dreux and Mathilde Enould de Livaudais (daughter of Jacques François Enoul de Livaudais and Marie Celeste de Marigny).

Charles Dreux answered the first call of arms made by the Confederate Government, three days after the surrender of Fort Sumter. He left New Orleans for the battlefield as Lieutenant Colonel of the Louisiana Guard Battalion. Three months later, at Young's Mills, Virginia, he fell at the head of his command, with the words on his lips, "Steady, boys! Steady!'

He was the first Confederate field officer killed during the war. His body, brought to New Orleans, 
was accorded a funeral that has passed into history as Louisiana's tribute to her first dead. The children, who were taken by their parents to see the funeral procession, have grown old and white-headed, but the memory of the martial music, the draped flags, and solemn files of soldiers in gray uniform, the flagdraped coffin, has never grown old or hoary. Many a child's heart passed from the innocent security of childhood at that hour into the full mature realization of what is meant by war, sorrow, country, patriotism and heroism.

Charles Dreux is described by those who knew him as a man of great personal magnetism; brilliant, eloquent, dashing. His picture shows him to have been, indeed, truly noble if not royal in appearance. His widow, on the fall of the city to the Federal forces, sought refuge in Havana, where their only child died. A brother of Charles Dreux, Pierre Edgar Dreux, who married Célestine Sanchez, was also killed in battle during the first years of the Civil War.

The name, transplanted from France over two hundred years ago, still maintains its freshness and vitality in New Orleans, contributing its quota to census and directory. The proud lineage still runs straight, connecting the old families of the past with those of the present. The descendants of Mathurin Dreux are to be met to-day in society and the business world, under the names of Beauregard, Dugue, Verret, de la Vergne, Livaudais, Jumonville, Destréhan, Fazende, Villeré, LeBreton, Déléry, and Soniat du Fossat. 


\section{CHAPTER V}

\section{A ROMANCE OF THE BAYOU ST. JEAN}

$\mathrm{O}$

THER settlers besides those of flesh and blood have given their name to the pleasant countryside of the Bayou St. Jean. Gayarré relates a romance, which the historians make a place for in their narratives, and which is still repeated by all guides. It deals with Charlotte, the beautiful daughter of the Duke of Brunswick, a paragon of virtue, beauty and talent, who was married to Alexis, the son of Peter the Great, after she had given her heart to the Chevalier d'Aubant, an officer of her father's household. On the day of her marriage he received a passport and permission to leave the country.

To continue, in Gayarré's words:

"Whither he went no one knew, but in 1718 he arrived in Louisiana with the grade of Captain in the colonial troops. Shortly after this, he was stationed at New Orleans, where, beyond what was necessary in the discharge of his duties, he shunned the contact of his brother officers and lived in the utmost solitude.

"On the banks of the Bayou St. Jean, on the land known in our day as the Allard plantation, there was a small village of friendly Indians. With the consent of the Indians, d'Aubant formed there a rural retreat where he spent most of the time he could spare from his military avocations. Plain and rude was the soldier's dwelling, but it contained, as ornament, a full length and admirable portrait of a female, surpassingly beautiful, in the contemplation of which d'Aubant would frequently remain absorbed as in a trance. Near the figure represented stood a table on which lay a crown, resting, not on a cushion as usual, but on a heart whieh it crushed with its weight, and at which the lady gazed with intense melancholy. 
This painting attracted, of course, a good deal of observation, but no one dared to allude to it. By intuition, every one felt that it was sacred ground, on which enquiry ought not to tread.

"Where was all the while the Princess Charlotte, the gilded victim of Imperial misery? One day, entering his wife's apartments, her husband requested her to receive a female scullion of her kitchen on whom he had bestowed his affections. She refused; he, heated by the fumes of his deep potations, worked himself into a paroxysm of frantic rage, and with wild gestures and terrific shrieks of a maniac, rushed upon her, and with repeated blows, laid her prostrate on the floor, senseless and cold in apparent death.

"The Princess recovered from her swoon, and found herself alone with her friend and bosom companion, the Countess of Kôenigsmark. Long did they discourse together in subdued tones. That night the Countess of Kôenigsmark entered secretly the Princess' room, and there was re-enacted that scene where Friar Lawrence counsels Juliet to feign death. The imperial funeral took place according to the plan which had been laid; the whole of Europe was deceived.

"With the two hundred emigrants who had arrived in March, 1721, there had come a woman who, by her beauty and by that nameless thing which marks a superior being or extraordinary destinies had, on her arrival at New Orleans, attracted public attention. She immediately enquired for the Chevalier d'Aubant, to whom she pretended to be recommended. She was informed that he was at his retreat on the Bayou St. Jean, and that he would be sent for. But she eagerly opposed it, and begged that a guide should conduct her to d'Aubant's rural dwelling.

"It was a vernal evening, and the last rays of the sun were lingering in the West. Seated in front of the portrait, which we know, d'Aubant, with his eyes rooted to the ground, seemed to be plunged in deep revery. Suddenly he looked up-the dead was alive again, and confronting him with eyes so sweet and sad, with eyes so moist with rapturous tears, and with such an expression of concentrated love as can only be borrowed from the abode of bliss above! What pen could do justice to the scene? Suffice it to say that on the next day the Chevalier d'Aubant was married to the mysterious stranger, who gave no other name to the enquiring priest than that of Charlotte. In commemoration of this event, 


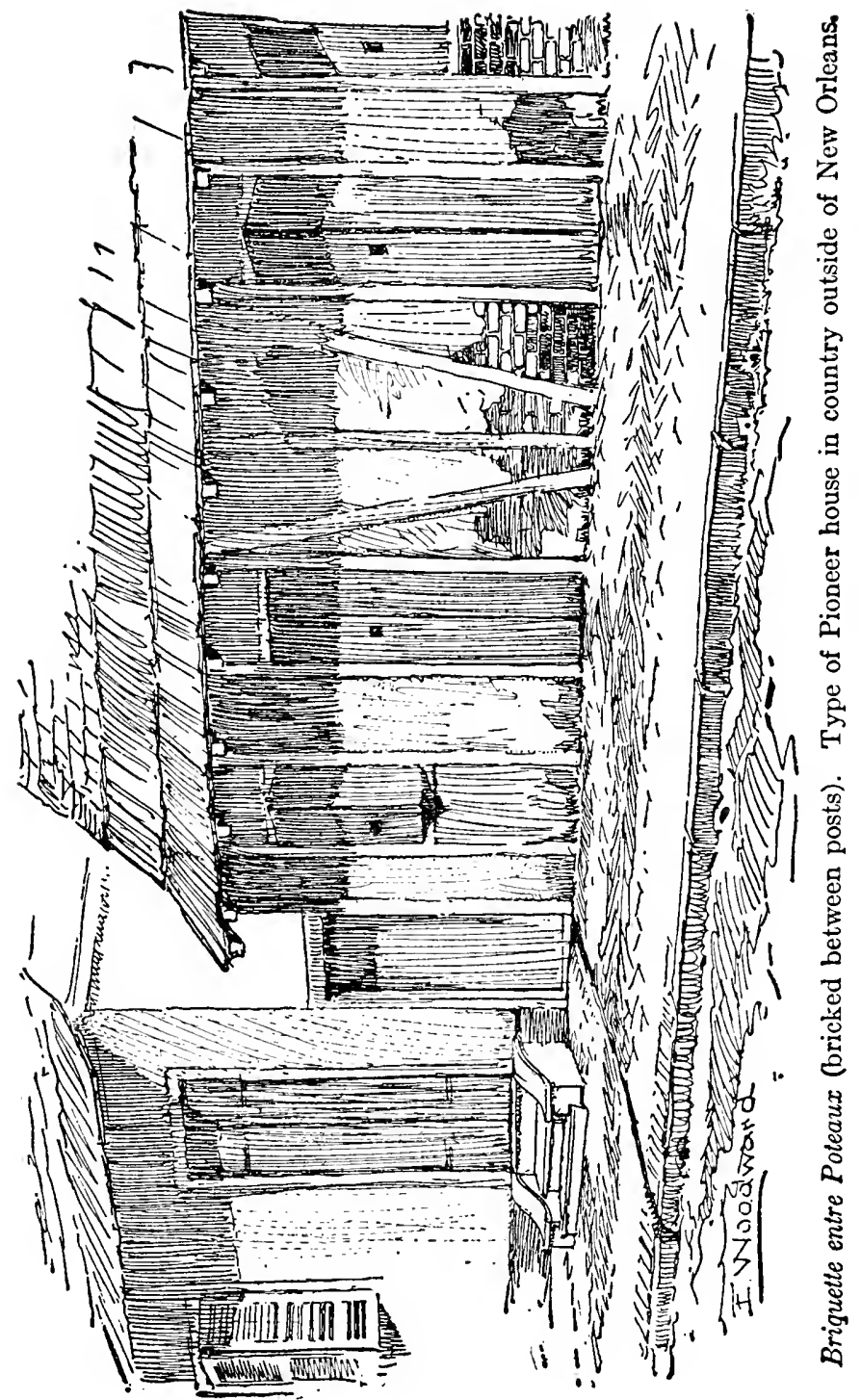


they planted two oaks which, looking like twins and interlocking their leafy arms, are to this day to be scen standing side by side, on the bank of the St. Jean, and bathing their feet in the stream, a little to the right of the bridge in front of the Allard plantation.

"Certain it is, that although d'Aubant and his wife kept their own secret, and lived in almost monastic retirement, rumors about their wonderful history were so rife in the colony, and the attention of which they became the objects subjected them to so much uneasiness, that d'Aubant contrived to leave the country soon after, and went to Paris, where his wife, having met the Marshal of Saxe in the garden of the Tuileries, and being recognized by him, escaped detection with the greatest difficulty. D'Aubant departed for the Island of Bourbon, where he resided for a considerable time. In 1754 , on his death, his widow returned to Paris with a daughter, the only offspring of her union with d'Aubant, and in 1781 she died in a state bordering on destitution."

The painstaking, conscientious historian, Hanno Deiler, after quoting Gayarré's account, ends by saying of it: "It is a pity to destroy such a pretty legend." Nevertheless he does so pitilessly. His cold-blooded investigations prove beyond a doubt that no such name as d'Aubant is to be met with in colonial documents. The marriage records of the St. Louis Cathedral between 1720-1730 register no such marriage.

"The legend, therefore," says Deiler, "may be pronounced a myth, although Allard's plantation is still pointed out as the dwelling place of the lovers, and the two leaf-locked trees by the bridge still bear witness to their happiness."

Picket, in his "History of Alabama," claims the couple as residents of Mobile. Tschokke, the German novelist, places them on the Red River. But no fact in her history is so firmly believed by the romantic people of New Orleans as this lovers' tale, and their dwelling place has been assigned to various other localities favorable to the seclusion of true love. 


\section{CHAPTER VI}

\section{DE PONTALBA}

$\mathrm{F}$ all the good old French names that her mother country contributed to New Orleans, not one has become so firmly rooted in the soil as that of de Pontalba. It has kept up so evenly with the growth of the city that it bids fair to become one of our most enduring landmarks.

The family came originally from the old province of Quercy, the country of the Cadurci, as indicated by the patronymic Delfau, a corruption of Delfaon (beech tree) in the Romanic language.* Jean Joseph Delfau de Pontalba, the first of the name in Louisiana, came to the colony in 1732, at the age of nineteen, with the grade of "enseigne en second," with the promise of promotion that would seem to stand for a certificate of friends in the best place for an officer to possess them-in the court or government circle.

The colony at the time was what would be called to-day in a strenuous period of her history. Périer was closing, with doubtful honors, his campaign against the Natchez to punish them for their massacre of the French a few years before. The

* From "Etats des Services du Sieur de Pontalba, Capitaine d'Infanterie. Archives du Ministere de la Marine." Paris.

De Pontalba was the name of a fief belonging to this family (in the environs of Higeac Depot); first assumed as a family name by the Louisiana officer. 
Company of the West had just again ceded their charter to the King; Périer was about to be recalled and Bienville was already selected to succeed him and take up again his old authority as Governor of the colony. Pontalba was at once ordered to the Natchez Fort, which was under the command of M. de Bénac. For a year he was busily employed learning something of Indian warfare for, as he wrote, the fierce, irreconcilable Natchez harassed the fort continually and kept the French on a constant pursuit of them.

After Bienville's arrival the young officer was ordered to New Orleans, where he remained three months. In token of the terms upon which he stood with Bienville, we have the following endorsement by the Governor, in his official report of the French officers employed in Louisiana:

"Pontalba has always conducted himself well; is intelligent, good looking, sensible, and attached to his profession.

"(Signed) Bienville."

During the two years following, Bienville was employed first in trying to detach the powerful Chickasaws from their alliance with the Natchez, and when this failed in preparing an expedition against them. Pontalba was stationed in command of the post at the Tunicas-the Baton Rouge post. When Bienville's armament was ready to proceed to Mobile, he and his garrison were ordered down the river to join it.

The interest in Bienville's graphic account of his unfortunate expedition in the Chickasaw country culminated, as all who have read it remember, in the description of the attack of a picked company of one hundred and twenty-nine grenadiers under the 
command of de Noyan, upon the stronghold of the Acquia village. Pontalba figured in the list of officers who led the attack and made a gallant effort to rally the men under the deadly discharge of the hidden savages. Our chronicle contains a short extract from de Pontalba's account of the expedition. The whole of it is a valuable addition to our archives, for we have only Bienville's report, or rather defense of it, and d'Artaguette's bitter arraignment, written in indignant grief over the cruel death in it of his young brother.

The year following this campaign, de Pontalba was made the commander of the post of Pointe Coupee, one of the most flourishing settlements in the colony where, as Bienville, writing the same year, states, a hundred thousand pounds of tobacco were produced annually.

Pontalba remained there twenty months, or until his services were needed in Bienville's second expedition against the Chickasaws - the one by the way of the Mississippi. He was put under the command of de Coustillac, who was engaged in establishing a dépôt at the mouth of the St. Francis River. He was sent twice into the Illinois country for provisions for Fort Assumption, and acquitted himself with such diligence that he accomplished the distance in a space of time so short as to seem incredible to his contemporaries.

When the futile campaign was ended by an unsatisfactory treaty with the Chickasaws, Pontalba came down to the city with the Governor; and two months later he obtained a leave of absence and sailed for France. Bienville's next report of the officer's serving in Louisiana recommended him for 
promotion with the annotation, however, affixed to his name: "Has served very well; seems to have corrected himself his very marked taste for commerce."

Pontalba remained in France for a year, and upon his return was sent by Bienville to the post of the Balize, perhaps to remove him from the temptations of again yielding to his mercantile inclinations. He remained at the Balize, however, only until Bienville departed from the colony and Vaudreuil arrived and took possession of it. He at once reappointed de Pontalba to his old post at Pointe Coupée.

According to the marriage certificate in the Cathedral Archives we read that in New Orleans, on the 4th of November, 1743, in the Parish Church, Messire Jean Joseph Delfau de Pontalba, Lieutenant of Infantry and Commandant of the post at Pointe Coupée, son of Messire François Delfau, Baron de Pontalba, Seigneur de Roquefort, Pontalba and other places, and of Dame Louise de Lombard (his father and mother natives of Montauban) was married to Dame Marguerite Madeleine Broutin, daughter of Messire François Broutin, Captain of Engineers of the King in the province, and of Dame Marguerite Madeleine Lemaire, native of the province. The bride was, as we remember, the widow of François Philippe de Marigny de Mandeville; her sister married Delino de Chalmette.

Pontalba remained at his post of Pointe Coupée ten years, serving the King and colony, doubtless with honor and with profit, but also to his own interest, according to gossip. Kerlerec relieved him from his position on account of the gossip, but stated explicitly that he, personally, did not believe it. 
Pontalba's ten years' administration at the post of Pointe Coupée was signalized by great prosperity. In 1749, he was advanced to the grade of Captain, and in 1759 was made Chevalier of the Order of St. Louis. He died in New Orleans in 1760.

Joseph Xavier Delfau de Pontalba, the son of the foregoing and the New Orleans de Pontalba, as he may be called, was born in New Orleans in 1754, but taken at a very early age (presumably upon the death of his father) to France, where he was educated. He entered the French Army at Sèvres. Louisiana, having become a Spanish possession, his history diverges from it. He was twenty-eight years of age before he returned to his native city. To copy briefly his record in the "Archives de la Marine," he was named to the regiment of Montauban; four years later was transferred to the regiment of Guadeloupe; attained the grade of Lieutenant and later of Assistant Adjutant of the regiment; took part in the campaign of Ste. Lucie, Granada. He gained distinction at the siege of Savannah, his conduct being praised in the highest terms in written certificates from his commanders, the Baron Stredink, the Count d'Estaing, and the Marshal de Noaille, on behalf of his son the Count de Noaille, in whose division Pontalba served.

Two years later, he figures as the hero in "A duel in the army in 1797," of which elaborate details were collated from official documents by his great-grandson, the late Baron Edouard de Pontalba (Paris, 1904). It appears that the young lieutenant, stationed then with his regiment in Martinique, too young, as he acknowledged, to know better, took upon himself to resent an affront which concerned 


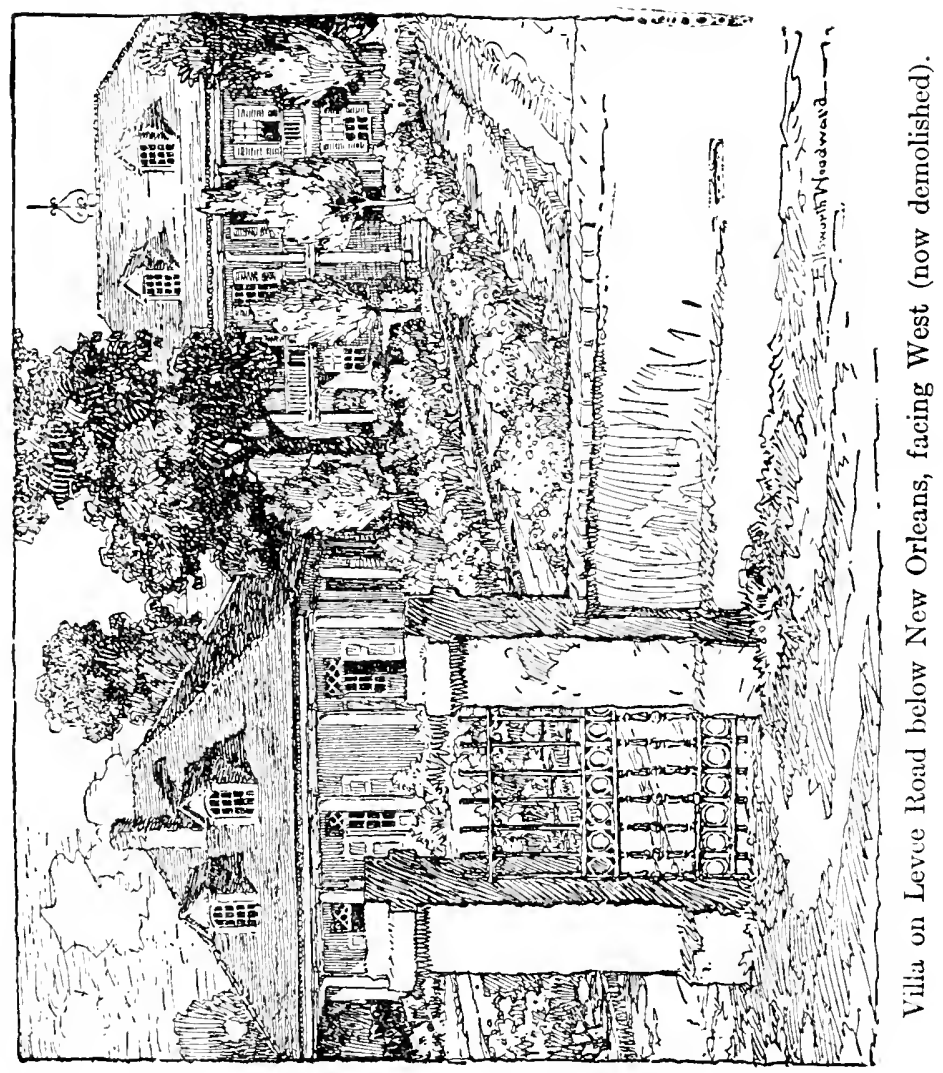


. 
in truth only his superior officer. In consequence, he was assaulted in the street by the enemy he had made and received three sword thrusts before he could defend himself. Bathed in blood, he was carried to the hospital, where he remained eight months. As soon as he was able to walk with a cane he left the hospital, determined to seek his adversary until he found him, which he did shortly afterwards in the street. He attacked him, but again fell wounded from a thrust in the side, his quick-footed foe making his escape.

On the advice of his friends and to save himself from a civil prosecution, Pontalba sought refuge in Martinique and remained there until his wound healed, returning to his regiment more determined than ever to call his foe to account. But after searching for him for six weeks he learned that " $X$ " (so the adversary is designated in the Lieutenant's account) had returned to France. De Pontalba was disposed to let the affair rest there, biding his time for revenge until chance should bring him face to face with his opponent. But a letter from his superior officer, written in the name of all the officers of the regiment, assured him that his honor required him to pursue " $\mathrm{X}$ " to France.

There was no avoiding the issue or the hint conveyed. De Pontalba obtained a leave for a year and hastened to France where, after diligent search, he found the man he sought and forced him to give satisfaction.

A duel in form took place. This time the adversary was wounded in the right hand and, refusing to continue the fight with his left, promised on his honor, in the presence of the four seconds (officers), 
that he would meet de Pontalba on the same spot in fifteen days. De Pontalba and his seconds awaited him punctiliously at the time and place appointed, but the Sieur "X" did not make his appearance, for he had left the country. Papers were drawn up and signed by the seconds, attesting the facts; and these, with certificates of what had taken place in Guadeloupe, were submitted to the Count de Genlis, Marquis de Sillery, Captain of the Gardes du Duc de Chartres, who was the supreme French authority at the time in questions of honor. This high officer, after careful study of the papers submitted to him and due consideration of the delicate affair, pronounced the decision that de Pontalba had acted as man of honor in every particular, and was entitled to the "esteem and friendship of his brother officers." De Pontalba was ordered to rejoin his regiment at Guadeloupe and resume his service. The fine imposed upon him for his infraction there of the public peace was remanded.

He retired from the army with the grade of Captain in 1782, and returned to Louisiana, casting his fortunes in with the Spanish Government. He was given a company in the native regiment of Louisiana, stationed in New Orleans, and later was made Colonel and Commandant of the Regiment des Allemands.

In 1789 , he was married to Jeanne Louise le Breton, daughter of Barthelmy le Breton des Charmeaux, Mousquetaire of the King, and of Françoise de Macarty.

Louise le Breton des Charmeaux des Chappelles came, as the old Creole ladies would say, from far back in Louisiana history. She was the grand- 
daughter of de Noyan, Bienville's grand-nephew, who had married the daughter of Nicolas Chauvin de La Frénière, the glorious Louisiana patriot executed by O'Reilly. It may be remembered that, on account of his youth and his very recent marriage, the young man was offered a pardon and his life by the Spanish General, but he refused to abandon his companions and his father-in-law, La Frénière, whose last words were addressed to him. The young widow of de Noyan afterwards married Louis Césaire le Breton des Chappelles. Their son, Louis Césaire le Breton, married Louise Françoise Macarty; and the daughter of this couple became the wife of Joseph Delfau de Pontalba.

After his marriage Pontalba entered the service of Spain with the grade of Captain. Seven years of peaceful, happy life followed, the only important event of which was the birth of a son, Joseph Xavier Celestin de Pontalba (1791).

The Pontalba family lived on their Indigo plantation outside the city facing the river where, following the example of thrift of their neighbors and friends, they drew their daily expenses from the profits of their garden and orchard, sending their filled-up baskets into the city every morning by their vendeuses. These were selected from their choicest slaves-strong, straight, sturdy young women who could walk miles holding a heaped-up basket on their heads without wavering, and who never failed to bring back the full amount of their sales, keeping their accounts in their heads and their money in kerchiefs tucked in their bosoms. (We shall read later Gayarré's description of them as he remembered them on the Boré plantation.) 
Madame de Pontalba had been reared as a daughter by her aunt, Celeste Macarty, the wife of Governor Miro. When Miro was recalled to Spain in 1792 he left his private affairs to de Pontalba as to a son. In 1795 Miro died, and his wife fell into a state of despondency and ill-health so alarming that her niece was summoned to her side. Without hesitation on the part of either husband or wife Madame Pontalba made her preparations to hasten to Spain. She took with her the little five-year-old son-the apple of his father's eye-although the voyage was fraught with danger. She had never traveled out of the province before and the separation seemed almost that of death.

It is to this separation that we owe the prettiest document without doubt in Louisiana historical archives: this is the series of letters, or rather the letter-journal written to her by her husband during nine months, day after day, from the 24th of February, the day of her departure, to the 10th of November, when he announces that he is on the point of leaving and will in three months be reunited to her in Spain. The picture of perfect marital devotion and a man's virile expression of his gratitude to the woman who for seven years had given him, as he writes, the enjoyment of the purest earthly bliss, would alone give to the letters a rare and unique interest and make the reading of them an intellectual treat; but we are concerned here more in the other interest they offer us of the confidential and frank description of the life he led in his enforced widowhood. The incidental details fill out a complete picture of what in truth constituted New 
Orleans a century and a quarter ago; its business, its diversions, its sorrows, its gossip and its truth.

The collection as a whole is so perfect in its way that to detach a leaf of it is to pull out a petal from a beautiful flower. With the exercise of self-restraint, only what was necessary to satisfy natural curiosity has been detached. "Tintin" Celestin, the little son, flits like an iridescent butterfly through the letters. We can see the father's eyes soften and grow moist over his paper as he writes about him; and our own eyes grow moist as we think upon the great tragedy awaiting the father and son as the result of their passionate love, the one for the other.

The personality and the family of the Baron de Carondelet, his wife and his little son, Angelito; his brother, the Abbé, who dies of yellow fever; the card parties at the Government house; the set of intimates who frequented them-all such personalia are new to the historian of Louisiana, and are presented here for the first time in literature. The description of the insidious advance of an epidemic of yellow fever-the first epidemic that came to New Orleans-and, day by day, the tale of its casualties recall to the dwellers in New Orleans only an oft-suffered misfortune, the catastrophic details of which are limited only by what human nature can suffer.

Pontalba describes the interesting young émigré officer de Coigne, his brief appearance in the social life of the place, his fever, his death; the beautiful and lively Madame de Rivière; the hospitable aunt de Macarty and her frolicsome parties; the other aunts, Madame d'Aunoy and Madame Jonchère; 
the shrewd and cunning (as he calls him) Don Andres Almonaster and his pettish wife, Louise de la Ronde; his intimate friend, Philippe de Marigny (the splendid host of the Royal Princes) and his scheming in a bargain to get ahead of de Pontalba (who showed himself not a whit behind him in moneymaking.

We are told of the house-building for himself and Madame Miro; the buying and selling and hiring out of slaves, with the black cloud in the distance, but ever getting nearer, of a rising of the slaves, spreading from the insurrection and barbarous outrages of the blacks in St. Domingo; the constant watchfulness of Carondelet to avert a repetition of the same in Louisiana; the secret, gnawing fear of it among the planters, and the consequent panic. And, as time goes, comes the infiltration of the rumor of a political change in Louisiana; the retrocession of the colony perhaps to France and in the end its probable domination by the United States.

The enumeration of it all seems endless. Not a letter has been omitted without a pang of regret; every one is important. What has perforce been left out has been done so with the hope that some day, by the grace of some divine historical benefaction, all the letters will be published in the full series as de Pontalba wrote them.

The first two weeks give the chronicle only of the days, the weeks of the wife's absence, of the lonely house, the desolate heart, the longing for news of what happens to the vessel. "What of his dear little love, Tintin? Does he talk of his father? Does he want to put his arms round his neck 'tighter, tighter,' to say good-night to him?" 


\section{A few extracts from the journal follows:}

"13th March.-I have been passing my day planting strawberries. I did it to divert me from my weariness. I no longer have the passion for gardening that used to furnish all my amusement. I see now that you and our son were the end and aim of all my occupations. If I cared for the flowers it was in order to see your plcasure in gathering them; I really never enjoyed the beauty of my strawberries except when we were together and amusing ourselves with the joy of Tintin in gathering them. I see them now covered with flowers without taking any interest in them. When I look at them I seem to hear the cries of joy of our little love, and I stand overcome with the saddest of thoughts. Where are you, mon amie? . . .

"I am gardening more than ever. Of all ways of passing the time I find it the least insupportable. With Augustin, when he has no hauling to do, and with Baptiste and Jean, I busy myself working in the garden. I had forgotten it completely, but on walking through it I saw in it magnificent cabbages, already headed, as fine as any in Europe; lettuce, too, fringed and headed, superb brocoli, and already some little saucers of strawberries. I gather them myself, sending the handsomest to my Aunt d'Aunoy (Mademoiselle d'Estréhan): the rest I share among friends.

“ . . . Just ask my little Tintin what he wants me to do with all these strawberries. There are two big bowls of them a day, large and ripe; ask him if he does not want to come back and let me fill up his little wagon with them. In truth, mon amie, I have a lot of them and I am passing for a great gardener. I am making presents of them. They are found so good that every one wants to plant them now and multiply them everywhere. Every one believes that I have made a particular study to produce things in different seasons from other people. In fact I am the only one at preseni with headed cabbage. I have put Jeannette to selling them; she brings me back six dollars a day and sells all that she has. She only sells summer cabbage, brocoli, and fringed lettuce. Dussuau (de la Croix) is jealous of my talent; he pretends that I make more than he does. I do not sell my strawburries: I give them away, but they would bring four dollars a day. Dussuau complains that his sellers are so poor that they bring back nothing. . . .

"From time to time, I pass the evenings at the Governor's (Governor Carondelet), when I do not go to my relations. It is 
the only house where I go. They play cards there-sometimes 'Bourre,' sometimes 'Coq.' Madame de Rivière does not like to lose, and gets seriously offended with those who do not treat her well at these games. Treating her well is to let her win money, and as I do not treat her well she finds that I play a very ridiculous game and criticizes it a great deal; and you know this does not make me more complaisant. Oh! mon amie, where are those delicious evenings that I passed with you and my son? I go out and I look everywhere, but never, never do I find aught that can replace them.

"24th March.- . . . All this bad weather has put our levees in the most unfortunate condition. I am afraid that le Breton (her brother) will not make any more than Pedesclaux. The crevasse at M. Port's has been abandoned. It has become so great that we are assured that it is a second Bonnet Carré.* Massicot has a large crevasse as well as Braud, near d'Estréhan. Besides the river is flowing over all the levees. Our fields are covered with water. Next year the planters will have to add a foot to the height of their levees.

"B1st March.- . . . I received a letter yesterday from M. Herrera announcing that he had forwarded the garden seed that M. Paul Miro had the kindness to send me. Although I have abandoned my garden, the seed will give me great pleasure. I announced their arrival to my aunt d'Aunoy, to whom I had just given an assortment I received from New York. That will give her certainty of making something out of their garden, which they wanted to give up because all their vegetables were brought back to them unsold. They are surprised to see my garden at present full of fine cabbages, brocoli, beautiful lettuce and spinach, without any cost to me. It is sold as soon as it gets to the market, but I prefer to send them to my friends. I have revealed my secret to them, which is to get my seed from the North. . . .

“ . . . I passed the whole of to-day at the Governor's. I tried to get from the Baron all the circumstances relating to the revolt of the negroes. It seems to me from what was told me that there was very little reason for the alarm that produced a very bad effect. The slaves are not ignorant of the reason why many planters have brought their families to the city. They will deduce from that, that they are feared, and this will give birth in their

* A very disastrous crevasse of recent occurrence. 
heads to projects that they never would have conceived otherwise. In fact, the planters have for fifteen days kept the government in alarm, and the clearest thing about it all is that there is no plot. The three negroes who have been arrested could only be convicted of having been guilty of seditious language tending to a revolt, but it could not be proved that any plot had been formed . . . and it now appears that there was more fear among the planters than danger to the colony.

"18th May. - . . Another very boisterous party at Gentilly. Tremoulet took charge of getting it up. A list was passed around in the circle of Madame la Baronne (de Carondelet). The men each gave five dollars in accepting and each one was to invite the lady he wished. I like to contribute to the amusements of others and so I did not fail to pay my share, with the tacit condition that my presence would be dispensed with. In truth I profited by the excuse given me by the rain this morning to remain at home.

"I know, mon amie, that it would give you pleasure to have me profit by any amusement that presents itself, and that is a reason for me why I should not miss any if there were a chance of getting any diversion out of them, but as I feel that I should bore as much as I am bored I should be very much out of place in them. It is not a privation but a heavy duty I have spared myself. When the ladies return this afternoon, I shall call on them and shall not fail to find some valid excuse for not going.

“ . . . Ask my little Tintin if he has forgotten our little crayfish parties: tell him I saw one this morning that interested me far more than the party to Gentilly. His little cousins d'Aunoy with Celeste la Jonchère were fishing for them, catching fire or six on their line at one time. I recalled the joy he would have had if he had been with them. I could see him, hanging over the ditch at the bottom of our field, screaming with glee whenever he brought one up. . . .

“. . Mon amie, the memory of all these little nothing's and that of the perfect happiness I enjoyed from your tenderness and kindness during the whole time of our union are with me all the time, and it is above any pleasure that society could offer me. If I could only know what you are doing at this very moment; where you are; what is to become of you; what your unfortunate situation is, and that of our little love; and if our good friends feel some consolation from your presence! 
"22nd May.- . . . Mdle. Macarty, with whom I passed the evening in her box at the Comédie, spoke a long time about you and of our dear good aunt. Tintin was not forgotten. When I meet with any one, mon amie, to whom such conversation is pleasing, I never tire. Such moments are the only ones that do not depress me. My little Tintin took much of my thoughts during the whole play. I seemed to hear him repeating, 'Down with your arms! The first one who advances toward me I will lay him low! . . . Tell him not to lose the habit of saying good night every evening to his papa.

"24th May.- . . . It was before your departure, I think, that d'Aunoy received a letter from Zenon Trudeau at the Illinois, announcing the arrival at his house of M. de Coigne, an émigré, the nephew of M. de Copineau, who asked him to interest himself in the newcomer and begged him to engage me, as well as Favrot and others who have served under his father (de C's), to do something for him. He praised him and d'Aunoy, who at that time took no other interest in him than what was inspired by his attachment to M. Copineau, asked M. le Baron (de Carondelet) if he could not do something for him. He wrote to de Coigne inviting him to come straight to his house, and he arrived yesterday morning. The la Jonchère family were staying with d'Aunoy, and his own house was full, so I hastened to offer a room in my house which d'Aunoy accepted with pleasure. He had begged de Coigne to look upon his house as his own home, assuring him that although his fortune was not in proportion to the size of his family, he would take charge of him. When I entered into the service, the father of this young man was Captain of Grenadiers in the regiment in which I was a cadet. He had a pretty, agreeable wife, of pleasing manners, whom we cultivated a great deal, and he used to receive us in a friendly way. De Coigne, the son, does not need this to inspire interest. He inspires it as soon as he makes himself known. I told d'Aunoy that I wanted to have my share in providing for him, and since d'Aunoy had invited him to eat at his house he must leave the care of lodging him to me. He has arrived naked after an emigration of two years, during which he has been in need of the necessities. I was with him this evening for two hours in his room, talking all the time of you and of our good aunt. $\mathrm{He}$ showed so much interest and he is in such full accord with all my sentiments that I find he is the one that I love most to talk to 
about you all. . . . Good evening, good night, I embrace you tenderly. . . .

“. . I I began my day, mon amie, with an action that pleased me very much, since I owe it to you, sending to Mde. E. what you left for her. I should like to have something as pleasant to do every day.

“ . . The son of M. D. has just arrived from St. Domingo. He left it only fifteen days ago. He pretends that the negroes there are absolutely the masters . . . and that at the Cape there are only forty or fifty white men, who are worse treated by the negroes than the negroes were ever treated as slaves. It seems that they want to be independent of everything white, even of the French Republic. A Spanish frigate which came into port was forced to leave. The negroes would not permit it to stay and, by threatening to sink it, forced it to withdraw. M. le Baron who, up to the present, has been so vigilant to protect us against suspicious folk, has relaxed a great deal lately. . . .

" . . . At last, mon amie, I am thinking seriously of building in front of the river on the Grand Pré lot. My plan is made; the materials bought; and the trade concluded. The news yesterday decided me. We received from Kientucky the Treaty of Peace between Spain and the Americans. They have the free navigation of the Mississippi from its source to the sea without paying any duty. They have New Orleans as a place of deposit for three years, and every kind of merchandise is allowed them except munitions of war. You can judge by that, mon amie, that this country is going to become one of the most prosperous in the world. The population will increase in an incredible manner; property will double in value; stores and houses will be rented at exorbitant prices and our city will soon resemble Philadelphia in the diversity of nations that will live here. One of the articles of the treaty permits liberty of worship and the Americans will be permitted to bring in their own lawyers to settle their differences. I believe that there will no longer be any Custom House, for it would be useless.

"This treaty is already ratified by Congress and should be, at present, with the Court of Spain. It cannot be long before we receive official notice of it here. It is to be put into execution six months after ratification, which would bring us to the first of next October. I think from all this that I shall be able to sell advan- 
tageously all my built-up lots. My intention is to sell the seven stores I have on the corner of the 'Contador,' as well as those I have in front of the Government House (on Toulouse Street, between Chartres and the levee), reserving sixty-five feet depth on the whole length facing the river, upon which I could at once put five stores. I cannot get any more tiles from Pensacola . . . I have just bought twenty thousand tiles at fifty-six dollars a thousand.

" . . Everybody is building. It is inconceivable the rapidity with which everything is being built in brick as a protection from fire. I have found nearly all that I need. I have bought them from Madame de Marigny through her husband, who prides himself on being a man of business. . . . This evening I went to the 'Comédie,' because they were playing 'The Honest Criminal.' The piece recalled to me the happiest time of my life, though it was very badly given. Henry inspired no interest in the role of the honest criminal. Fontaine and Madame Marsay were the only ones that gave pleasure. . .

“ . . . Behold me a gambler! Mon amie, look out for yourself! Quick to my rescue! Your presence by absorbing me will help to speed this kill time, for I cannot call it otherwise. In short, I went this evening to the card party (at Madame Carondelet's). Madame Landry, Madame Gauthier, Madame Macarty and others were there. The ladies are now reconciled to Madame la Baronne, whom they find very tactful. In fact you cannot find ladies more amiable in society, more friendly, more simple, more affable, than these who now frequent her parties and who are attached to her. The number would be greater if it were not for 'la petit Rivère,' who estranges them by her airs with them; besides she never loses a chance to say a risque thing, which she takes for a witticism. When modesty forces the ladies to pretend not to notice it she thinks her witticism is lost or, no doubt, that their minds are obtuse and that they have need of an explanation-which she gives at once without being asked, always at the risk of making some one always blush. So she is never at her ease except when she is in the company of la Baronne, Madame Macarty or Madame Maxent. . . . " . . . I am charmed at having M. de Coigne staying with me; he often keeps me company; an amiable, solid young man, sensible and, I think, very frank and honest. He is of a very gay temperament. He tries to recommend himself to me so that I shall make 
a good marriage for him, one that will relieve him of his troubles. For four years he has been without resources, living from day to day, and never knowing what fate awaited him on the morrow. He seems grateful towards those who have assisted him, although we have not done much for him. He came here with only the clothes he had on his body. We introduced him everywhere after we had provided for his needs. I think we shall be able to get him out of trouble. In the meantime, I shall see that he needs nothing. D'Aunoy, seconded by his wife, treats him as if he were of the family.

" . . . You would be astonished to see how the city is building up and all with terraced roof and frame work covered with brick or plaster; there are hardly any traces left of the fire. ${ }^{*}$ Barthelmine Borgone is rebuilding the house I sold him on Chartres Street and his neighbor who bought a lot from Pierre (Marigny) is building also. I judge that this great rush of building will make rents fall and for this reason I feel like not putting the ceilings in the houses of your aunt and leaving the woodwork very simple so that the capital required will not be so great and for fear she might not receive the rent $I$ flattered myself she would. I am following the same course with mine which I am not furnishing with ceilings or windows. . . .

" . . . Pardon me, mon amie, I must write you one word in spite of my fever. You know it is impossible for me to live without concerning myself with you, and that as long as a breath of life is left me I will make it serve to repeat to you that though my strength may decline my love for you will never weaken. My attacks of fever have been long, the interval between them short before the chill seizes me again. I have hardly had any headache. . .

" . . De Coigne who loves greatly to visit, begged me to take him this afternoon to call on Mesdames Dreux and Cespédez. The former announced to us that in a few days she was leaving for Gentilly and she invited us to come next month and hunt grassées with her. As for our cousin (Cespédez), she inquired all about the poor emigrant and asked him a thousand questions, ending by telling me that he was a charming man.

* The great fire of 1787 that burned out the old original city of Bienville. The new city that was built was practically the handsome old-world city we see to-day. 
"14th June.-In passing through the street yesterday I saw the children of M. L. The poor little wretches seemed to be in the greatest poverty. If $I$ had found you at home when I came in and had told you about them you would have done something to help them. I did not want them to suffer too much by your absence so I tried to guess what you would have done. I have so many half-used things that you left here in the armoires-stockings, drawers, vests, chemises, skirts, corsets. I cleared the house of all that was useless and sent it all to her, for the poor mother will know how to make use of it to clothe her children. What was only a nuisance to me will be very useful to her. I added ten dollars, thinking of the pleasure you would have had in sending them. She has thanked me in a way that shows me how timely the little assistance was. . .

"15th June.-M. de Coigne has returned from his little trip, and I am very glad of it. It is necessary that $I$ should not be alone at home; I am too much plunged into sad reveries that harm my health. He is well satisfied with the houses of Robert, Mde. Marigny, Destréhan, Robin, etc. He wishes to return there of ten, but never, he says, to Mde. Boré. He did not see the husband, and the wife became so exalted in conversation, with so much fire and so much passion, that he had doubts for a moment whether he was in New Orleans. Miss Hortense seemed, he said, to have the air of admiring with astonishment all that her mother said, and he had hopes for no recourse in that quarter. He has become well informed as to what would suit him; it seems he made enquiries. He understands nothing, he says, of the management of slaves, and even less about business; he sees no other resource for him than a supportable marriage, and in this is all his ambition. Céleste Marigny would suit him well, but he fears the rivals who surround her; he would prefer Mdle. Emme, because he sees in her more possibilities, and less delay; Mdle. Collet did not excape him either; he is careful to pay frequent visits there and if he loses all hope in these quarters he will see if it is possible to fix the attention of her who was able not to give way before the attack of the poor great Captain of the Grenadiers, Chs. de Bouillé.

"16th June.- . . . Your son will imbibe such principles from you that it gives me pleasure to think that he will have a sensitive heart. That would be the handsomest present that his good MIaman and his excellent Marraine could make him. Never miss an occasion 
of rewarding him for any trait he shows of sensibility, kindness and benevolence. At his age we receive the impressions that remain engraved in us. Accustom him early to know the price of the true pleasures of doing good. If during the Winter he meets some poor little boy of his own age, ill clad, encourage him to ask you for enough to buy him a little coat. Let him give it himself, let him believe that the little creature he has clothed would have died of cold. Let him take some poor little boy under his protection and try to find a pleasure in being good to him. Let him see from time to time the picture of suffering; make him know that he might some day be in the same condition. What delicious joy, mon amie, if I could see my son sacrifice his playthings for actions of charity and humanity! Such impressions are, in my belief, easy to make upon children, particularly when they are, like your son, of a good disposition. What is neglected in education is the heart, which is just where we ought to begin it.

"16th June.- . . . Inspire him above all with the strongest hatred of lying and deceit, being very careful yourself to be always truthful with him. I have often seen people deceive little children to spare them some little disappointment-conduct as detestable as it is dangerous. More children have been ruined in this way than in any other. Never make a promise to your son that you do not mean to keep; never bind a promise with assurances and never let him do so, or he will not look upon a simple promise, a simple yes or no, as a certainty. . . . Tell him not to talk "nigger" (Creole), but to learn Spanish. . . .

" . . . This is your feast day, mon amie, the day that usually dawned for me more beautiful than any other seems very sad to-day and it seems to me emptier than any other. My little love must have given you his good wishes, his Marraine would not have let him forget that little duty. May Heaven, mon amie, reunite us soon! That is the most ardent prayer inspired by the wish that I cherish with my life to see you happy; I could not be so myself unless it be granted. Good night. . . .

“ . . . Chalmette arrived two days ago with his family; all of them very well. He is the one of all my relations to whom I am the most attached and I am delighted to have a little time with him before his departure. His family is rery interesting. His daughters have grown a great deal; Victoire is very pretty and gay; she has natural wit and great sprightliness, and she has developed 
much since you last saw her. The elder is serious; speaks little, but to the point. Nothing to be said as to her figure but all praise her character. The youngest will be the prettiest of all; the mother, who worships them and with reason, congratulates herself upon getting back from the Post so that she can give them what teachers we have here for music and drawing.

"Chalmette tells me that his little fortune amounts to forty thousand dollars. He would like to get a little establishment outside the city so as to live more economically. I suggested to him two pieees of land next to d'Aunoy that Martin, the tailor, wishes to resell: one hundred and twenty feet front by two hundred and twenty depth. I could get them for him for eight hundred dollars on a long term. He went to see the property and charged me to close the sale, congratulating himself, with cause, on his luck. One hour afterwards he writes me that Marigny, whom he had told of his acquisition, did not think it an advantageous one, and that above all he drew his attention to the danger he would run in case of a siege and he begged me, therefore, not to close the bargain.

"Poor Chalmette: He has the greatest confidence in Marigny. It needed only one word from him to turn him against the acquisition of the piece of property and make him renounce it at once. Very well! But would you believe it? He did it to unload upon Chalmette his own plantation below the city! I do not believe he will succeed in this. I do not believe that Chalmette will decide to put so much capital in such a piece of property, two leagues below the city. It would absorb his entire fortune before he had provided himself with negroes, animals, and implements, etc., etc., which he would need. On the property I proposed to him he would find all these things, with all the resources besides for his table: garden, dairy, ete., and he would be in easier reach to get his daughters established as they would be where they could cultivate society. His wood would cost him nothing and, like others, particularly Mademoiselle Macarty, he could get a return from his dairy, and even his garden could add to his daily revenue. I made him see all these advantages, which he appreciates as much as I do, and he renounces them! I am sure he will repent, but then it will be too late. I am so sorry that I have decided to buy the property myself. . . . If Chalmette repents I will cede it to him. . .

" . . . I was invited to another bathing party to-day at Madame Macarty's. She gives these parties very often. Madame 
la Baronne, her daughter, and Rivière are at the head of them. Madame Andry and her sister are always among them, and Peytavain never misses one. The ladies go at eleven o'clock in the morning and pass two hours in the water, going under head and all. I make the great heat my excuse and always get out of the parties, and as it is not long since $I$ have had the fever I have not the appearance of ill-will. The truth is, I am absolutely out of place in such parties; they bore me as much as I bore others in them. Always absorbed in sad reflections, the amusements of others sadden instead of enlivening me. If you were here with our son, if your absence did not render me insensible to everything else, perhaps I could amuse myself. . . . I forget myself, mon amie, in talking to you. It is very late; a terrible storm is raging outside. I paid no attention to it until a violent clap of thunder awoke me from the dreaming that I would have given myself up to for still another hour. Good night. . . .

“ . . . I cannot see this fifth month pass away with calm, mon amie. It is about time that I was hearing something from you and my son; I fear as much as I long for a vessel from Bordeaux. The most distressing thoughts pursue me incessantly. . . . My God! . . Perhaps at the end of this uncertainty I am to hear of the greatest, the most terrible of misfortunes that could be! With what ardor would I make the sacrifice of my life if I am not destined to pass it with you and with my son. . .

“ . . . This morning at four o'clock I went below to Marigny's to settle my account with him; I passed an hour there and we talked of Chalmette and his fortune. He told me it would be better for Chalmette to have a plantation than the small property next to d'Aunoy, and he gave me all the details of his affairs, which he took charge of during the six years of Chalmette's absence.

All this confirms me in my decision not to leave my business to him, as I once had the intention of doing; although we had agreed formerly that he should take charge of it. I shall not speak to him any more about it, and I shall try to find someone who will not mix my affairs with his, for such a business always turns against the one for whom it is made. Very surely had I been in the place of Marigny I should have invested Chalmette's funds in such a manner that, on his return, he might have been sure of getting them back when they fell due in case he wanted to turn them into something else. . . .

"Two days before the arrival of the courier, Madame Andry 
told me at the Government House that she would give up her loge, if any one wished to buy her share of stock. As the letter of your aunt announced to me that it might happen that you might soon return, I took her share, because her loge is the best in the opera. She asked me two hundred and thirty dollars for it. Madame Almonaster proposes to me now to change the box with her; if so, she will return to me sixty dollars. I ask her one hundred in order to pass the box and my share on to Chalmette for one hundred and thirty-two dollars, and so make a gain of one hundred dollars to him at the expense of Louison (Madame Almonaster). I will arrange that with Chalmette.

"8th July.-Captain Robin (just arrived from Philadelphia) has brought back the son of Marigny and of Madame Dreux. They are returning, having made only a short trial of the educational facilities there.

17 th July.-There was another large bathing party to-day at Madame Macarty's - the closing one, for it will be the last. The water has gone down so low that the ladies must have bathed in the mud. It was more impossible than ever for me to go, though the ladies have such a scarcity of men that they press me to accompany them. . . . To-day they were reduced to Peytavin, their faithful, unshakable cavalier, Andry and the Chevalier (the master of the house), (Chevalier Macarty). These three champions had to hold their own against the ladies of the Government: Rivière, Maxent, Gauthier and Andry. Your aunt (Madame Macarty) renews these parties every week, but she will have to give another motive to them now, for the canal to the mill does not offer water for bathing any longer. . . .

" . . . I am giving a contract for the houses I still have to build on the Grandpré lot. The workman pledges himself to finish them by the first of January. They are to be two little houses ( 34 feet by 28 feet each), with one little story and a kitchen. The two will come, I think, to eight thousand dollars. I have a contractor for the carpentering; and another for the masonry. I furnish all the materials. You see, I am getting everything ready so as not to retard my joining you and your aunt. . . .

"21st July.-Marigny brought his son to see me this morning. I blamed him for recalling him so soon (from school), but it seems that at the North one receives a very poor education. He has brought back the vices of the country and the rough manners of 
the Americans. He holds himself excessively bent over, he chews (tobacco) continually, swears at everything, and looks bored by everything he sees as well as by everything he hears. He speaks English rather well and has learned it in a very short time, which proves that he does not lack intelligence and that he would have learned anything else had it been taught him. His father complains of his indifference. On his arrival he came up to his father very slowly and told him good day as if he had not been absent, and this after having embraced Bernard! Oh, mon amie, I should feel indeed that $I$ was to be pitied if my dear little Tintin should ever become as indifferent to ane! But no! He has your delicacy of feeling and will never give us cause for that fear.

"23d July.- . . Here I am with something more to do, all on account of taking that share of stock from Landry! I never thought of the bother it would give me. The management (of the theatre) is going very badly and now it is being robbed; the stockholders govern, but none of those charged to supervise is doing his duty. If things go on this way we will be forced to give up the theatre. As soon as they saw that I was a stockholder, they all turned to me to straighten out their finances. There was a meeting of stockholders to-day in which I represented fourteen persons, some of them owning two shares of stock, who had asked me to act for them: Mmes. Maxent, Montaigut, Guillemard, Almonaster, Bouligny; Messrs. Marigny, Ramos, Lachaise, Fouvargeues, etc., with the result that all who were present at the meeting unanimously made me manager. Although I was representing fourteen I got out of it and named Pedescaux in my place, but they all united to beg me to supervise the management. I could not refuse; but I am going to be the bette noir of the actors, for I saw myself forced at once to lay down some rules against which they at once protested. I shall neglect nothing to get out of cette galere.

“ . . I I passed by Madame de la Ronde's this morning on my way from my work; she was so insistent that I had to stay to breakfast with her. Madame Cespédez saw a ring on my finger. She said, 'What! A ring! And it seems to be a pretty one too. Let's see it. I declare I shall write to my cousin about it. What, made of hair!' And without ceremony she took it from my finger and put it on her bosom: 'In truth it seems to be made for me. How pretty it is. How new! What admirable work! Two hearts pierced; two doves tied by a ribbon that tightens as they separate, 
with the device that the further they go from one another the tighter it is drawn. How pretty the idea! How admirable! Oh, my cousin, I can never give it back to you. Do not expect it. It would be impossible.' You can imagine how miserable I was. 'But why should you prize it so? If it were from Madame Miro or your wife-well, of course! But surely my cousin could not have had the time to have had it made in Bordeaux! Besides, she would never think of it! Take care: if you care so much for it I shall write to my cousin!' And on the instant she flew away, to reappear without the ring. I said nothing, taking it all for play; but she had put it into her head very seriously to keep it and it went so far as to provoke me out of my good temper to get it back from her. She declares I am very unpleasant to refuse her a trifle that gave her pleasure.

"8th September.- . . . We went this evening to the reception of the famous Knight of Charles III! (Don cin dres almonaster.) That poor man is never satisfied. As soon as he gets one thing he strives for another! Now his mind is full of the title of Brigadier and he can talk of nothing else. Madame don Andres is pouting at me still, and for some time has been distant to me; although I went to the reception of her husband she showed no wish to be reconciled with me. I would not have believed that she could have kept up her spite against me so long for a little piece of society pleasantry in which I had no part.

"Some time ago she was playing cards at the Government House when I was there. Madame Rivière, who loves to amuse herself with childish pranks, had tied a long hair to a coin with a hole pierced in it which she drew away slowly whenever Madame Almonaster tried to take it. This she repeated over and over again without our cousin seeing the joke and who was constantly trying to get hold of her picayune. Madame Rivière was choking with laughter as she whispered to me! Louison thought that we were making sport of her; she murmured, frowning, that if that sort of thing continued she would render tit for tat. Madame Rivière grew frightened, and I whispered to her that she was exposing herself to a scene. Then she stopped; but the other one remained convinced that she had been made the subject of a joke, and that I had started it, so she has never looked at me since except with eyes of indignation.

"The reception of her husband followed the usual custom. He was enveloped in the great mantle of the Order and his train was 
carried by three lackeys in red. An immense crowd followed him as he went in state from the Cathedral to his dwelling. He placed himself, in his mantle, at the door of his drawing-room, where he affectionately kissed on both cheeks all who approached to greet him, to the number of more than three hundred. About eight o'clock in the evening he sent up from the Place a balloon, accompanied by a small display of fireworks at the end of a collation consisting entirely of sweetmeats, they played cards until ten o'clock. Folch, who stayed through all of it, told me all this, for I did not go up to greet the new Chevalier. He has not yet finished the balcony on the house of my aunt, there is still only one end of it laid, and as long as I have any business with him, I wish to see him only at a distance.

"18th September.-The deluge of rain continues; it has been so for three or four days without ceasing. I have never seen such a continuous rain here, above all in the middle of September. No matter how disagreeable the weather is, it pleases every one; all over the city pecple are terrorized by the fear of an epidemicthe women above all; they even went so far as to wear garlic on their bodies and carry hartshorn; everywhere tar is being burned. The doctors and priests concealed the number of deaths; now that there seems nothing more to fear, we learn that there were at least fifteen or seventeen deaths a day; but this did not last long. . . . “ . . . Mme. Le Blanc died this morning; her son, Terence, is dangerously ill. M. de Turpin will not last through the day. $\mathrm{He}$ is the grandson of the Maréchal de Lowendal and Chevalier of Malta; he is thirty years of age, and had a fine constitution. $\mathrm{He}$ is a connection of Baron de Carondelet. M. Lafargue, whom you must have met in Bordeaux, is also very low. Many Englishmen and Americans are dying. In burying a Protestant lately, five corpses were found in the back of the Protestant corner of the cemetery, apparently covered only with branches and leaves. They had not taken the time to bury them. Such negligence is enough to give us the plague. The greatest precautions are now being taken to put order into such things, and to discover the authors of the affair and to punish them.

"I repeat, mon amie, do not alarm yourself about me. I am well and am taking good care of myself. I go very seldom into the city, and I shall take care not to put this letter into the post until the epidemic is over.

"22d September.-More bad news! Turpin died yesterday after- 
noon, and his doctors ordered him to be buried at once. One hardly took the time to put him in a coffin. No one could be found to carry him. The whole city is in alarm. Many have gone away to the country. Every one you meet is asking news about some sick person. A Captain of the Mexican Regiment is very ill, and Madame Gauthier, wife of the Major, is in danger. In spite of it all, I think the panic very mal à propos. I remember that after the fire of 1788 there was a greater mortality than now.

"I am not satisfied with the condition of Polidore; his crisis of fever now is the worst he has had, and his illness is taking an alarming character. Zerbin, going yesterday to see a workman of Montreuil who died to-day, was suffocated with the bad odor of his patient, and an instant after he was taken with the same fever. He is, they say, in the greatest danger. Madame Rivière and Mademoiselle Phelipa are frightened to death. Madame Macarty, who never comes into the city, has invited them to come over to her on the other bank of the river. The Baronne consents, but she does not wish to leave the Baron alone, and they are all begging him to go with them. He is firmly resolved not to do so. He thinks if he goes away it will increase the panic, which is only too general. It would only need for him to go out of the city for everyone to rush to the country. . . .

"24th September.-The sickness does not cease, mon amie. Everybody is frightened, particularly the strangers. Besides the seven or eight who have died in the hospital, we counted up yesterday nine or ten more, so that to-day more than eighty left for the country. Those who have no friends there have gone to Barataria and to the other side of the lake. They will, of course, carry the sickness with them. We are all agreed that it is the Yellow Fever that rages nearly every year in Philadelphia, and that the Americans brought it in.

"25th September.-As for Annette, she is sold for the same price that you paid for her-nine hundred dollars. . . . If I cannot bring her to you I shall myself learn how to make Gombos and Calas, so as to be able to show some of your servants in Spain how to make them. I have already laid in a nice supply of excellent orange flower (water or syrup) for my good aunt, and I shall leave an order to send some every year to Barcelona.

". . . Every thing you tell me about my son, mon amie, gives me sweet satisfaction. Tell him that I have answered his little 
letter and have sent him some toys and pralines. Be at ease about my voyage. I have too much at stake not to take all the precautions you desire. I feel that I exist more for you than for myself; that I owe myself to you, to our son and to our aunt . . . I do not know what our political situation will be at the time of $m y$ departure, fixed for February. We may then be at war with the English and even with the Americans. M. le Baron is always expecting some rupture. On the other hand, rumors of the cession of the province to France are being confirmed. All here believe it. The Baron is the only one who is sure there is nothing in it and he must have some particular reason for his belief. At any rate, the situation we are in is very critical and my fate very uncertain. Good night, ma bonne amie, take care of yourself and of our good aunt and may I at least be able to provide for you both comfortably before we have here the scene of a revolution!

"3oth September.-. . . The North wind is still continuing, although not so strong as it was. It has absolutely destroyed all contagion; we have no more epidemic. We are assured that all those who went to the country were not attacked and that very few of those who were acclimated died. It was the same with the soldiers; the mortality was greatest with the newcomers, particularly among the English.

"2d October.-At last, mon amie, lere is the month of October! Already a year since we sold our plantation! A year since you were to leave to join our good alint! I have every reason to think that in four months I shall be on my way to you. The bad season is now over; I shall profit by every minute to finish my business. I think that by the end of October, there will no longer be any question of the sickness. A few who were attacked are still dying. Mademoiselle E., the one who wanted to marry de Coigne, has just died; and Miller, the artist, who lived at the Marigny's. Mademoiselle de la Chaise is, they say, beyond hope; the sacrament was administered to her last night. This morning I went to see Madame Dreux. She was in bed, and although I had not been to see her for a month she received me in a very friendly way. I like her very much; she is not sensitive and I think she is a good friend. . . . As I am certain she will finish by getting married again, I believe for her own sake it would be better for her to marry de Coigne than any one else. $\mathrm{He}$ is a man, refined and honest, and I am sure gratitude for her kindness will make him exert himself to the utmost to render her 
happy. She receives him with distinction and he goes there often. Yesterday he spent four hours there and I have no doubt that on her recovery the affair will be carried through at once.

" $8 d$ October.-I am putting the finishing touches to my houses on the corner near the Government House (Toulouse Street and the levee), and the two will be finished and ready to sell at the end of the weck. I am sure I shall be able to sell them before my departure if they are finished.

"We have not seen anything of the Baron for five or six days. His family is with Madame Rivière, on the other side of the river, with Madame Macarty. I crossed over yesterday morning with la Baronne, who had come over to hear mass. She told me that the doctors did not understand anything about the Baron's pains in his jaws and ears and that he had decided to take the tisane of Dr. Ramos. Without doubt, it is not to interrupt the treatment that the ladies have decided to remain on the other side of the river. The Baronne complains continually of trouble with her breathing and heaviness in her head: Madame de Rivière, of general pains all over. She is totally changed; not only has she lost her color but she is distressingly thin. She is terribly afraid of dying and is getting ready to leave for Bordeaux, even at the risk of being a suspect.

" 6 th October.-. . . Marigny thinks that because I am going away I should let him have my slaves for nothing . . . For a long while he has been asking me for Baptiste; but at last, as he talked no more about it, I sold him to Sigu and then he reproached me. Sigu, seeing that I did not leave, asked me cither to give him Baptiste at once or to break the trade. Thinking of Marigny I broke the trade; then Marigny offered me four hundred dollars, although I had broken a trade on his account by which I could have sold for five hundred. A few days ago Fortier offered me five hundred if I would deliver the slave at once, and I asked twenty-four hours to think about it. I did this on account of Bernard (de Marigny), who had begged me fifteen days ago to keep Baptiste for him. I asked Marigny in the evening if he had decided to take Baptiste; again he asked me the price. 'Five hundred.' 'Oh! that is too dear! I am buying him for Bernard with his own money, and you must be considerate.' 'I am giving you the preference: five hundred dollars are waiting for me elsewhere.' 'Oh well! Give me two days to think about it.' 'Willingly.' I went to see him this morning. 'Well, what have you decided?' 'Oh, Bernard cannot 
spend so much money as that. He must renounce the idea.' Thinking myself at liberty to do so, I left him at once to go and close with Fortier. And now Marigny is very much offended!

" $\gamma$ th October.-. . . The sickness, that seemed to be disappearing, is giving us new anxiety. The English who have not left the city are, of course, the victims; a second demoiselle Fuselier has just died and one of her brothers is very ill. The whole house of that poor Delery is in the most pitiable condition: four of his daughters are in danger. M. le Baron has at last given in to the solicitation of the ladies to remain on the other side of the river. I go over very often to play cards with them.

"9th October.-. . . A great crowd of us to-day were at the Macarty's. I took de Coigne with me. We are all at our ease there and we can do what we please. the Baron himself is quite different there; he takes part in all the frolics and he even appears to be amused. He seems to have left behind him, in the city, all the responsibility of his official position-to be only a man of society, and an amiable man of society.

"The ladies come even into our rooms to play their pranks on us. . . . They make a racket all night at our doors, but I am deaf to all their wild noise. They needed to get to the country. In the city so much sickness had saddened them to the point of giving them the blues. They now won't hear any talk of the epidemic on the other bank; they have prohibited all news of the kind and think only of amusing themselves. This afternoon they all went on horseback to the Laporte Crevasse with all their young men; they ran races and committed all sorts of extravagances. I am good only to listen to their talk about their wild foolishness; I am not gay enough to participate in it.

"One of the Delery young ladies died to-day. Several others of the family are in danger. Doctor St. Martial, attacked by the same fever yesterday, is in a state to cause great uneasiness. Good-night, ma bonne amie, good-night. . . .

"19th October.-Poor St. Martial died this morning after three days of illness. Mademoiselle Macarty is distressed; he was the only physician in whom she had any confidence. Mademoiselle de Kernion is very low. There is being distributed here a little printed pamphlet that came from Spain which many people are making use of to protect themselves against illness. It is a receipt of Massdeval, a celebrated physician of Charles III. It has been used of ten in this 
contagion but without success. As for the Baron, he is in the hands of Ramos, ${ }^{*}$ whose tisane he has been taking ever since he went over to the other side of the river. It is doing him such immense good that the Baronne has decided to take it herself. She began the treatment yesterday and Madame Rivière said to-day that if it did the Baronne good she would make use of it herself. In truth it is astonishing to see how quickly all the Baron's ailments disappeared from him. He suffered intolerable pains in his jaws and ears and had continual insomnia. From the fourth day he was relieved and, at present, he has completely recovered both sleep and appetite, and his pains are gone. So that Ramos is now a wonderful man, and all the ladies are praising him.

"I went yesterday to see Madame Dreux. She asked about you and our aunt. No matter how much one neglects her, she is always the same; she pardons her friends for all their faults toward her. She is made for society and I like to cultivate her. She seems to receive de Coigne with pleasure and I predict that as soon as her health is re-established there will be a marriage. Ever since he lost hope of Mdlle. E., de Coigne has turned his eyes in her direction, and I think with success. D'Aunoy thinks he should come to the point at once; however, I think that under the circumstances, no matter how de Coigne proceeds, he will make a success of it.

"We are living in a state of the greatest disquietude here and I dare not persuade myself that $I$ have the time to arrive in Spain before the breaking out of hostilities. There is no more talk of 'the line' (line between Spain and the United States, fixed by the treaty) on one side, and on the other there is every disposition to evade the treaty.

"Mdlle. Kernion died to-day. Mme. Sognac (Soniat?) who was completely recovered, but who had nursed the Montégut child through its serious illness, has been attacked by the same illness and is in graver danger than from her first attack. In the midst of all this sickness I keep in good health. My plate is never filled with cnough roast beef for my breakfast, and when I take supper at Madame Macarty's one would think it was my only meal during the day. I ate this evening for my supper a whole plateful of sorrel, taking out the hard-boiled eggs, a side-bone of turkey, some butter beans, a lot of asparagus, three heads of lettuce and Roquette in

* A Spanish physician famed in the city for his cure of yellow fever. 
salad, some quince preserves, fritters, sponge cake and three rolls, and I still had some appetite. Every day it is the same. I think it is the Quiquina in bark which I have received, and I chew every day, that gives me this appetite.

"October 6th.-We went this morning to the mass and internment of the poor Abbé (brother of the Baron de Carondelet); his brother is inconsolable; and truly, this worthy ecclesiastic merits the grief of all who knew him. He died with all the tranquility and resignation of a man who has nothing to reproach himself with. Poor little Angelito (the son of Baron de Carondelet) is still very ill; his fever has not yet abated.

"October 7th.-Angelito is somewhat better; there seems a little hope for him. Montégut's son, who was in the greatest danger, is entirely recovered. Our Bishop leaves to-morrow for his diocesan visit to the Attakapas, Opelousas and Natchitoches. On his return, he is to go to Pensacola. Good-night, dear one whom I love alone, and of whom seven years of happiness have so well taught me the value!

"October 8th.-The son of the Baron de Carondelet goes from bad to worse; the only hope is in his youth. My heart bleeds when I think of the condition of this unhappy father! My God! if it should happen that my son should be exposed to a similar danger, satisfy Thyself with the sacrifice of my life and save his! The state of this father and mother is deplorable. Still crushed by the blow that took from them the Abbé, in whom they had found a brother, a friend and a tender mentor for their only son, they have now to tremble for the life of this only child.

"October 9th.--Little Angelito is entirely out of danger. Mon amie, it is impossible, being a father, not to be interested in the condition of this unhappy family. I saw the Baron this evening; he is not yet himself; he doubts sometimes that it is really true that his son has been given back to him. The death of his brother struck him so hard that he could not believe that his son would recover. His fever was of the same character as that of the Abbé. Philipa has recovered. Madame Rivière was of the greatest assistance to them; she never left the bedside of Angelito, and she alone had the courage to make him take the remedies.

"October 10th.-I passed the greater part of the evening at the Governor's house; the ladies received me, and I was not surprised to find them consoled; the almost certain idea that they would lose Angelito, once banished, they felt a joy which was indeed 
a paliative of the grief at having lost the Abbe. I saw the child, he could not be better.

"19th October.-The sickness is diminishing a little under the fresh North wind that has been blowing for two days; nevertheless, there are two or three deaths every day. The sickness is particularly fatal to unmarried women. Mdlle. Nancy, that English woman who lived with Madame Oquon will not, they say, live through the day. The Baron de Stephnelt, the German who brought a letter of exchange to me, died after two days. The city is nearly deserted; my stores that were all taken are abandoned; there are only the two on the levee that are retained. More than one hundred and fifty English have died in the epidemic and more than three hundred have gone away to the country or elsewhere. Clark was so frightened when his last clerk came to give in his account that he would only speak to him from a distance. Three clerks died in his own house; the fright has given him a little fever. His physicians are more afraid of this imagination than of the sickness. But with it all, mon amie, I am well and have a good appetite, and I am too busy with my longing to get to you to give the sickness a chance to get hold of me. . . .

"The Baron has completely recovered his health. He left the Macarty plantation yesterday; his wife, who continued taking the tisane of Ramos, finishes with it to-day. She will go on with the Sarsaparilla for several days yet; she used to have her glass of it brought into the card parties by her husband, who would exhort her to take it. Madame Rivière preaches the same thing to her husband but he rejects the proposition, and this prevents her from taking it. You can imagine the fun all this causes, but I find no amusement in it; it bores me. I am doing everything possible to shorten my time here but I am continually thwarted. My works are going along with inconceivable slowness. Almost all the masons and English carpenters are dead; the few that are left are run after by everybody and they are paid a price beyond all reason. But in spite of that do not think that $I$ shall be a day later in getting to you than planned. The sale of my houses is made and I will leave the contracts to my agent. . . .

"17th October.-Every day, mon amie, I have had to announce to you the sickness of some one; now I can make up by telling you of their recovery, for almost all are getting well. The epidemic does not give us any more uneasiness. Marigny was attacked yesterday, 
and the physicians say he is in danger, but I believe it is only to give him importance. I saw him yesterday and he was up, although he did have fits of vomiting. . . .

"22d October.-Lafon arrived a few days ago. He had left his family all well but he found that his eldest son, a charming child of nine, had died two days before his arrival. Despau, whom you met on the plantation, arrived yesterday from Pointe Coupée, and he found that his little daughter of eleven had died after two or three days of illness. . . .

"24th October.-More bad news for your poor friend! A vessel that came in yesterday reported meeting an English frigate which ennounced that Spain had declared war on England. If that is so, my courage will give out! And I learned from the Baronne yesterday, under the seal of the greatest secrecy, that the Baron had the strongest reasons for believing that in three or four months the King of Spain would publish a cedula to accord freedom to all slaves in his dominion. If that should happen in so short a space of time we will find ourselves absolutely ruined, for all our creditors are slave-owners who under the circumstances will pay no one, and the greater number of them will go into bankruptcy. . . .

"25th October.-Marigny has at last found a way to get something out of me at a vile price! But his manner of doing it gave me pleasure, because I very much love his son Bernard, who is my godchild. The child came to beg me to sell him Antoine, my little Mulatto of nine, but very large for his age and very robust. He told me that it was for himself and that he did not have much money. I answered that with his godfather he would always have enough and that he could take Antoine and give me any price he thought proper. 'I will see about it,' he said. Yesterday I went down below to breakfast with them. After talking a long time with his father, Bernard came to me, saying, holding his head down, 'I have thought of what you said, godfather, and I thank you. I will gladly take Antoine but I have only one hundred and sixty dollars.' 'That's all right, my friend, send and get him. Did I not tell you to make the price yourself that suited you and it would be mine? You can send and take him whenever you wish.' He thanked me. His father was present during the conversation without coming into it the least in the world. Now I have only Julien left, whom I do not wish to sell unless his godfather (another slave) buys him to give him his liberty; and Charles, whom I will set free; Pelagie, Madeleine, and Augustin, 
whom I will not sell for less than their value, in which case I will hire out Pelagie and Madeleine and put Augustin at Tremoulet's (the hotel keeper) to learn how to cook. . . . And then, if slavery is abolished, I shall not suffer any considerable loss.

"'OSth October.-I slept last night at Macarty's, where the ladies were waiting to renew their tricks."

He describes how the clothes of all the gentlemen were stolen during the night so that when they arose in the morning they could find nothing to put on; trousers, shoes, coats-all had been taken. Fortunately, the ladies had all gone away, taking even the children with them. They had locked all the doors of the places where clothing was kept, and had taken even the oars of the skiffs. The gentlemen had to breakfast in their shirts after searching in vain from garret to cellar to find someone to help them. Finally, they decided to cross the river to their homes and get clothing there. The sans culottes excited much laughter when they arrived in the city.

"I arrived home at eleven o'clock. Mon amie, will we never be through with sickness? I found de Coigne there with a little fever which has never left him since yesterday. I think it comes only from a slight cold, but I have my fears, for a month past there are no fevers that are not dangerous. Good-night, I leave you to go back to him and arrange so that he will not need anything during the night. Good-night.

"29th October, 8 o'clock at night.-You know the sensibility of your husband! Judge then what my heart is suffering! I have just closed the eyes of my unfortunate friend, de Coigne. He expired at half-past seven o'clock, perfectly conscious to the last moment. Good-night, I leave you to go to d'Aunoy, who has been helping me with him without interruption. . . .

"Both October.-I cannot yet convince myself of the death of poor de Coigne, although I saw him expire. After rather a restless night he found himself better yesterday morning; his pulse was weak but he was without fever. I sent for Davo, but I could not get him until I went for him myself. During my short absence he had changed completely. Davo found him in danger. At one o'clock I called in Montégut who was of the same opinion. They prescribed the remedy of Massdeval and told me if he did not get better he must put his affairs in order. At three o'clock he had an oppression on his chest and a difficulty in speaking. Father Louis then came to 
administer the last sacraments. He still showed his gay, pleasant temper, and his quickness to seize a chance to make a witticism. He was always smiling when speaking to me, but showed no sensitiveness about his condition or regret at leaving his friends.

"About six o'clock when he was given the remedy he had to take every hour, 'good,' said he, 'give it to me. I must die according to rule.' At the same time he said to d'Aunoy and to me, 'Each one in his turn.' At two o'clock he wanted to go into the salon, and he sat by the fire there for more than an hour. From there he went into his room. He complained, touching his nose, that he had lost the sense of touch. 'I do not feel any longer what I touch; see how our poor machine goes to pieces.' When Father Louis told him that the King of Kings was coming to pay him a visit, 'Oh, it is you who are bringing him!' And so on to the end in the same tone.

"He took everything that was given him to the last, when he asked me to send for a little box of papers he had left with Clark. He said he wanted them. I sent. A moment later he asked if they had come, adding that he wished they were there. He was very fond of Zenon Trudeau and of his mother, but he did not even mention them, and showed no sign of feeling about his own fate or about his friends. At seven o'clock he asked to go into the salon again. We did not wish him to do so but he persisted. We supported him to the door, when he was taken with convulsions in the arms, legs and face. We had to carry him back to his bed. The convulsions that were caused by his weakness ceased when he lay down. He continued to talk to us, though with difficulty, until half past seven.

"He died after a struggle of a minute. About three o'clock spots of gangrene began to be seen and after his death he became covered with them. After giving my orders for everything to be done, I left him to the care of Jeannette, Pelagie, Polidore and Charles. He was buried this morning at nine o'clock. We could not find anyone to carry him to the church or cemetery. Banique, Polidore and Charles had to do it.

"I understand nothing about this fatal sickness; it is a kind of pestilential fever. You know well, mon amie, my love for you dictates to me all the precautions useful in such a case. I always had camphor on me and plenty of vinegar. We have used two demijohns of vinegar sprinkling the rooms. I had some quatre voleurs ('four thieves vinegar,' an old Creole preventive against contagion) 
to use on myself, and my good cousin Mannette provided me with a little sachet of camphor (to wear). The servants were all sprinkled with vinegar. I chewed constantly the quinine that I received from Cadiz. Ma bonne amie, I did it all for your sake for I was too affected to think of myself.

"De Coigne's sickness was the same as that of the Abbé de Carondelet and of many others, but none were carried away so rapidly by it. I shall sleep again to-night at my aunt d'Aunoy's. I have had all the rooms aired and everything that de Coigne used put outside immediately after his death. I sent his keys to the Baron begging him not to have any judicial expenses; telling him that de Coigne had arrived here unprovided, and that all he had had been given him by d'Aunoy and me. We wanted all they saved to send to his mother in Bordeaux. I do not know what the Baron will do. All of his effects sold would bring very little. The most solid thing de Coigne left was one hundred and fifty dollars that I gave him, which would be very useful to his mother, but which the auditor would eat up very quickly if we let him. Good-night, my dear, I have need of rest. I passed last night in a state of agitation that prevented my closing my eyes. I embrace you with my whole heart, and my good aunt and Tintin.

" 31 st October.-I could only sadden you with my reflections, mon amie, and so I will restrict myself to writing you only a few lines. I am inconceivably sad and I have no one near me in whom I can find consolation. I loved de Coigne; he merited all the sentiment I had for him and I have had the misfortune to lose him just when I had learned to know him and was certain of making him my friend. I lost him without having had the time to render to him the care that was due him and without ever being able to hope that we could save him. . . The day has been passed in whitewashing my house with lime.

"A man named Viard, a Garde du Corps' émigré, a handsome man of thirty-five, well-to-do, a friend of de Coigne who came here six months ago, and whom I saw very often, has died also of the same disease, but after five days. And that clerk of Tricou's who had the quarrel with Theodore died this morning. We congratulate ourselves from time to time that the epidemic is over, but it always comes back worse than ever.

"1st November.-I am this evening at Macarty's. I crossed the river at nightfall to sleep there after finishing my business in the 
city. I think the precaution very useless, for my poor friend did not live long enough to leave the germ of his malady in my house. To-morrow I shall sleep at the d'Aunoy's, for in spite of your aunt's welcome I perceive that her fear is so great that my presence makes her uneasy for her family. She takes the greatest precautions. She never crosses to the other side of the river and never allows a servant who has done so to come near her. Nevertheless it seems that the sickness is diminishing and the physicians assure us that there is very little in the city. I know of only one case at present-Mlle. de Blanc, the sister of Madame du Forest, who is in great danger. I shall not come back here; your aunt is so sad, she adds to my melancholy.

"2d November.-M. Boré is making fine sugar, sirop and tafia; he has that man who was staying with Mendez. It is said that he will make twelve thousand dollars (gourdes) on his crop, and for that he has only thirty-five hands.

"Piguery, a young man of fifteen, died after three days; de Gruy, who is ill, seems to be going the same way. We hear that all the ports of North America are quarantining boats that come from Louisiana. I am sleeping to-night at d'Aunoy's. Your aunt, in her care for me, puts in my room aromatic herbs, and juice of wild orange, burns sugar in it and scatters everywhere little bags of camphor. In short, she is taking all precautions imaginable to escape the scourge which is becoming milder every day. We hope that the first rain will put an end to it. For eight days we have had a heavy mist, thick but dry, to which the continuation of the deathly fevers is attributed.

"Srd November.-The aide-de-camp of the French General (Collot) has just died, regretted by all who knew him.

“' 4 th November.-This evening 'Eugenie' was given, followed by a compliment to the King and to the Baron. Minerva and Thalia appeared to recite a piece written in a prose worthy of a cabaret. It was almost all in praise of the Baron. He was flattered in the most servile manner and in the most tasteless way for a full hour until Phelipa, who is very bright, grew impatient of the platitudes that were being served in it. Two hands were made to appear clasping each other, representing the King of Spain and the French Republic, with the epigraph: 'Let us be ever united.' Not an actor pleased me. Mme. Durosier acquitted herself very poorly in the rôle of Eugenie. The little Bohémienne took it upon herself to massacre even the 
rôle of 'Mlle. Clairette.' But the piece recalled precious memories which are now only regrets.

" 4 th November.-Philips has just died. He was a young Parisian that Maxent brought with him from Paris. Mlle. de la Chaise is still between life and death. Her passing away has been announced ten times and she always resurrects; but now only a miracle can save her. I am writing from home; I had it whitewashed three days ago and the odor has all passed away.

"6th November.-Champigny, who has just cut my hair, complained bitterly of his wife who had struck him over the arm with the tongs. He wants to leave her and proposes to come with me to serve you and your aunt as a valet. I accepted his proposition with pleasure; that is, after he has thought it over seriously.

"Although the fevers are diminishing they are still very fatal.

" 8 th November.-The dry North wind we are having has dissipated the bad atmosphere, and the fevers that were so putrid and malignant are no longer dangerous.

"1Oth November.-At last, mon amie, here we are in full winter! I think it is going to be a very cold and rough one. Everyone is rejoicing over the cold that has completely freed us from the fever. My work is beginning to lighten. The two houses alongside the Government House with their kitchens are under way. My terraces and those of my aunt are repaired. Her houses are rented for a term of one year, but not for as high a price as I flattered myself I would get. Nevertheless, the house on the corner of the levee will bring a rent of $\$ 178.00$ a month and the one on the Place $\$ 118.00$. No one will rent the store under the apartment of the bishop. That one will be a pure loss. My eleven stores are finished; five are rented; no offer at present for the six others.

"Adieu, mon amie, I am going to send this packet to the courier; there's not an instant to lose. When you receive it you, I believe, can have the sure hope of our reunion three months later. Good-bye. Take care of yourself and my good aunt and Tintin.

"Pontalba."

Resigning his position in the Spanish Army, he left New Orleans in 1797. His friend Carondelet left a few months later in the same year for his new post of Quito. Madame de Pontalba, with her son and Madame Miro, joined her husband in Paris. 
While living there he wrote a full Memoir on Louisiana to be submitted to Napoleon. Bernard de Marigny, de Pontalba's godson, who was in Europe and presumably in Paris at the time, gives his personal coloring to the usual bare statement of the fact. He declares that Napoleon, being aware that a Louisianian of high intelligence, Joseph Delfau de Pontalba, was in Paris, thought proper to consult him as to the advantages and resources Louisiana might offer to France.

De Pontalba's paper is pronounced a masterly production by the best of judges, Charles Gayarré. Its wonderful clearness of political insight, and the complete knowledge exhibited in it of the condition of the province in its relation to Spain and the United States, had seemingly a convincing effect on the mind of the First Consul. It was presented to him on the 15th of September, and fifteen days later the Treaty of St. Ildefonso was concluded, by which Louisiana was retroceded by Spain to France.

A careful reading of the paper to-day warrants the inference that its effect may have been still further influenced in predisposing Napoleon's mind in favor of the ultimate cession of the province to the United States. Marigny, in his later paper, "Réflections Politiques," clearly indicates this. The following extract is a good example of de Pontalba's judicial tone toward the revolution against Ulloa and the subsequent surprising result of the Spanish domination in gaining the hearts of the Creoles, and, as in de Pontalba's case, the loyal services of the French officers.

\footnotetext{
"After having granted to Louisiana all that might be in her power, France would, in the event of taking possession again of it, still
} 
have done nothing for her if she did not give her as Governor an honest, frank, just and good man who, by his conciliating temper, would gain the affection of the inhabitants. They are of a mild, sensitive and remarkably grateful temper. The statement of one fact alone will be sufficient to show how much $I$ ought to insist upon this point. After having done in order to remain French more than it was then permitted to subjects to do, after having seen the solicitations of their delegates rejected by the court of France, the inhabitants of Louisiana, after having deliberated among themselves, came to the resolution of relying on nothing else than their courage, which was the sole resource remaining to them. The result was the expulsion of Ulloa.

"O'Reilly arrived with an army. He had caused himself to be preceded by words of peace, indulgence, and forgetfulness or the past. The colonists abandoned by the mother country thought that they were no longer bound to nurse and preserve for her the love which she rejected. They gave themselves up to the hope of an endurable condition under a new master and received him without resistance. O'Reilly's conduct is but too well known. It exasperated every heart and caused the new domination to be abhorred.

"The Count of Galvez made his appearance and inspired the public with confidence; for he was distinguished for the affability of his manners, the sweetness of his temper, the frankness of his character, the kindness of his heart and his love of justice. Receiving in $\mathbf{1 7 7 9}$ the news of the declaration of war against the English, he convened the colonists around him. 'Let them who love me follow where I lead' said he; and the next day fifteen hundred Creoles, among them many heads of families, gathered round him, and were ready to march to the enemy."

On the $3 \mathrm{~d}$ of October, 1802, Pontalba presented a petition to the First Consul, stating that he, Joseph Xavier Delfau de Pontalba, one of the principal propriéteurs of Louisiana, where he was born, had renounced his rank in the army of Spain, and that the transfer of some of his fortune to France showed his desire of becoming a French citizen once more, and proving his devotion to France. He stated that he has given the Minister some notes on the relation 
of the United States to Louisiana, and on the colony in general, which the Minister had found of use; he asks, therefore, that his previous service in the French Army also be taken into consideration and that he be appointed Adjutant-General without pay in the French Army; asking only the honor to serve the French Republic. This is annotated by General Victor: "Colonel Pontalba had given valuable notes on Louisiana."

The Minister of Foreign Affairs makes a report upon the petition that Pontalba, having renounced service with Spain, would be very useful to France in the newly-acquired colony; that he had furnished an interesting Memoir and asked the grade of Adjutant-General without pay. Decrès annotates it: "This has been presented to the First Consul, who has commanded that a prepared commission be presented to him." Decrès soon after sends him the commission with the intimation that it is accorded, with the hope that he will coöperate with the new Captain-General (Victor) and Prefect toward the prosperity of the colony of which France takes possession, and which she wishes to see flourish.

But neither General Victor nor Pontalba came to New Orleans. In 1807, de Pontalba bought the magnificent château of Mont l'Evêque (dep. Oise) where he enjoyed, as he had often declared in his letters to his wife, what would constitute the realization of his highest ideal of human felicity-a life passed in the family circle with her, his son and their good aunt, Madame Miro.

Here the little boy Tintin (Celestin de Pontalba) grew to young manhood. When still a boy, in 1804, he had been made a page of the Emperor. Five 
years later, when but nineteen, he was given the grade of Sous-Lieutenant of a regiment of Chasseurs $\grave{a}$ cheval, at the request of Marshal Ney, Duc d'Elchingen, who states to the Minister of War that the young man was related to his wife; that he was a youth in whom he took the greatest interest, and whom he desired to attach to himself later as aide-de-camp. In 1811, Ney writes further to the Minister of War that the young de Pontalba had served under him at the siege of Ciudad Rodrigo and Almeyda, had made the campaign of Portugal, just terminated, and had shown himself brave, zealous and active in service, asking as a particular favor that he be promoted as aide-de-camp. Napoleon himself countersigns the order for the promotion.

The next official paper in the "Dossier Pontalba" grants a leave of absence for six months that the young Sous-Lieutenant may go to New Orleans to contract a marriage. De Pontalba was accompanied to New Orleans by his mother.

The marriage figured for over a century in New Orleans' social traditions as the most important one ever contracted in Louisiana. According to the standards of the time, a standard fixed by the parents and not by the children, it was a perfect one, uniting as it did the only son and heir of the rich and distinguished Baron de Pontalba, with the only daughter and heiress of the wealthy Don Andres Almonaster, the famous benefactor of the city; the donor of the Cathedral, a schoolhouse, a hospital, a chapel, and the builder of the Cabildo; also a Chevalier of the noble and royal Order of Charles III, and the standard bearer (Alfarez Real) 
of the Royal and Illustrious Municipality of New Orleans, to quote from the Spanish register in the Cathedral.

Don Andres had died in 1798, leaving a great fortune to his wife and two daughters, Andrea and Micaela. Andrea survived her father only a short time, and her share of the estate went to increase the portions of her mother and sister. Micaela, sixteen at the time of her marriage, had been educated in the Ursuline Convent, and had never seen the world outside her native city and her mother's circle in society. She was not good looking, but had intelligence. She had been asked in marriage (the fate of heiresses) by every bachelor in the community, but her worldly-wise mother, the pettish "Louison" of the Pontalba letters, had other views in her head and was deaf, it is said, to the prayers of even her daughter, who had given her heart in an unworldly-wise manner to an impecunious youth.

Madame Almonaster wrote cheerfully to the Baron de Pontalba in a letter (written according to the standard of the day):

"My daughter has no inclination for any one; she wishes to see her cousin; she says, "What a pity if such a pretty marriage should fail!' They seem to be made one for the other." . . .

As for the young groom of twenty, nothing is known of him beyond his official record already quoted. According to his portrait, he was a remarkably handsome young officer in his uniform of the Chasseurs; his face, too soft and pretty, was indeed the face of a petted only son, who had been fed through childhood and youth on tender smiles 
and words of endearment. It was a great contrast to that of his stern, strong father, the Indian fighter and sturdy soldier of Bienville, the shrewd business man, that we know in New Orleans.

Dispensation was obtained for the degree of consanguinity, and in order to hasten the affair for the publication of the usual number of banns. To quote the account at the time, the young couple set out from the altar to France, accompanied by the two mothers. The Baron awaited them in Mont l'Evêque.

The next document concerning him comes not from the "Archives de la Marine, Dossier Pontalba," but from the "Procédure de M. le Maréchal Ney, par devant le Conseil de Guerre." Among the effects of the Marshal seized at the time of his arrest was found the following letter:

"PARIs, 11th of July, 1815.

"Monsieur le Maréchal,

"It seems to me that, in the event of your deciding to leave France, you would give the preference to Louisiana over other parts of the United States; that colony would, in truth, offer you moro agreeable inducements than the Eastern parts. You would find in the manners, character, and language of the people, formerly French, a way of living more conformed to your own. Life there is not only much less expensive than in New York, but it is much more in accordance with our habits. The one reason to be alleged against that part of America is the sickness that of ten reigns in New Orleans, during the months of 7 bre and Sbre. But it does not extend outside the city. One is not attacked by it in the country; therefore all men of means retire to it at that period, and nothing retaining you in the city you could easily seek shelter from the danger. You would find among my relatives and friends in Louisiana, a welcome even more cordial than is bespoken in the letters I enclose to you. . . . When you enter the Mississippi River, you will have to ascend it for thirty-six leagues. The Captain forwards the mail to the city, from the mouth of the river, by a skiff. Therefore by sending to 
Marigny the letter I addressed to him you can count upon finding him at the landing to meet you.

"Make use of me, M. le Maréchal, and count upon it that on all occasions you will find in me the same devotion that $I$ have never ceased to show you."

Pontalba's letters to Marigny and others in New Orleans have already been quoted. But New Orleans was not to have the honor of receiving, nor the people of New Orleans of entertaining, in their hospitable manner the noble and distinguished Marshal. He was, as we know, executed in the gardens of the Luxembourg five months after de Pontalba's letter, written, one cannot avoid the surmise, not only to give an invitation, but also to convey an intimation in the way of advice; and, involuntarily, another surmise arises in the mind of a New Orleanian, that de Pontalba may have ventured still further and may have suggested the rescue of Napoleon from St. Helena. It was proposed, according to a faithful chronicle in the city, to convey him in a swift-sailing vessel to $\mathrm{New}$ Orleans, where a house was built for him-a stately mansion that is still standing awaiting its imperial guest to-day as in 1815. The Battle of New Orleans and glorious defeat of the British had given the city no inconsiderable fame in 1815 ; and the gathering in the city of a distinguished band of old warriors from the Napoleonic army may have seemed to de Pontalba an opportunity for escape and safety that the Emperor would have been wise to seize.

Two years after his marriage, Celestin de Pontalba's resignation was accepted and he was freed from all military service and permitted to retire to his home in the magnificent estate of Mont 
l'Evêque, where lived also his father, mother and aunts, Madame Miro and Mademoiselle Macarty.

During the early years of the marriage three sons were born: Celestin, Alfred and Gaston. Madame Almonaster re-married soon after and died in 1827. Her fortune went to her daughter, Micaela. Young and immensely wealthy, even according to the standards of Paris, Micaela was not unnaturally tempted to enjoy her advantages according to the tastes of Paris. She bought a magnificent hôtel and furnished it in a splendid way, and gave entertainments which even the haughty and aristocratic society of the Faubourg St. Germain attended.

The Baron made over to his son the château of Mont l'Evêque (whose garden was the finest in France) and the family, including always Madame Miro and her sister, Mademoiselle Macarty, retired to a new home bought in the outskirts of Senlis.

But Micaela cared not for the country. When she paid unavoidable visits to the stately château of Mont l'Evêque, she carried with her a princely retinue of servants, and generally a cortège of fashionable friends and the leading actors of the great companies. She built a theatre in her grounds and acted in it herself. In short the Creole heiress followed the beaten path of her kind, in life as in fiction. The story is a commonplace one. Her husband cared only for the quiet pleasures of domestic life. His father, mother, aunts, children and wife constituted his world. The brilliant round of Paris pleasures grew distasteful; the extravagant expenditure of money abhorrent.

Estrangement between husband and wife followed and practical separation. In short, what had 


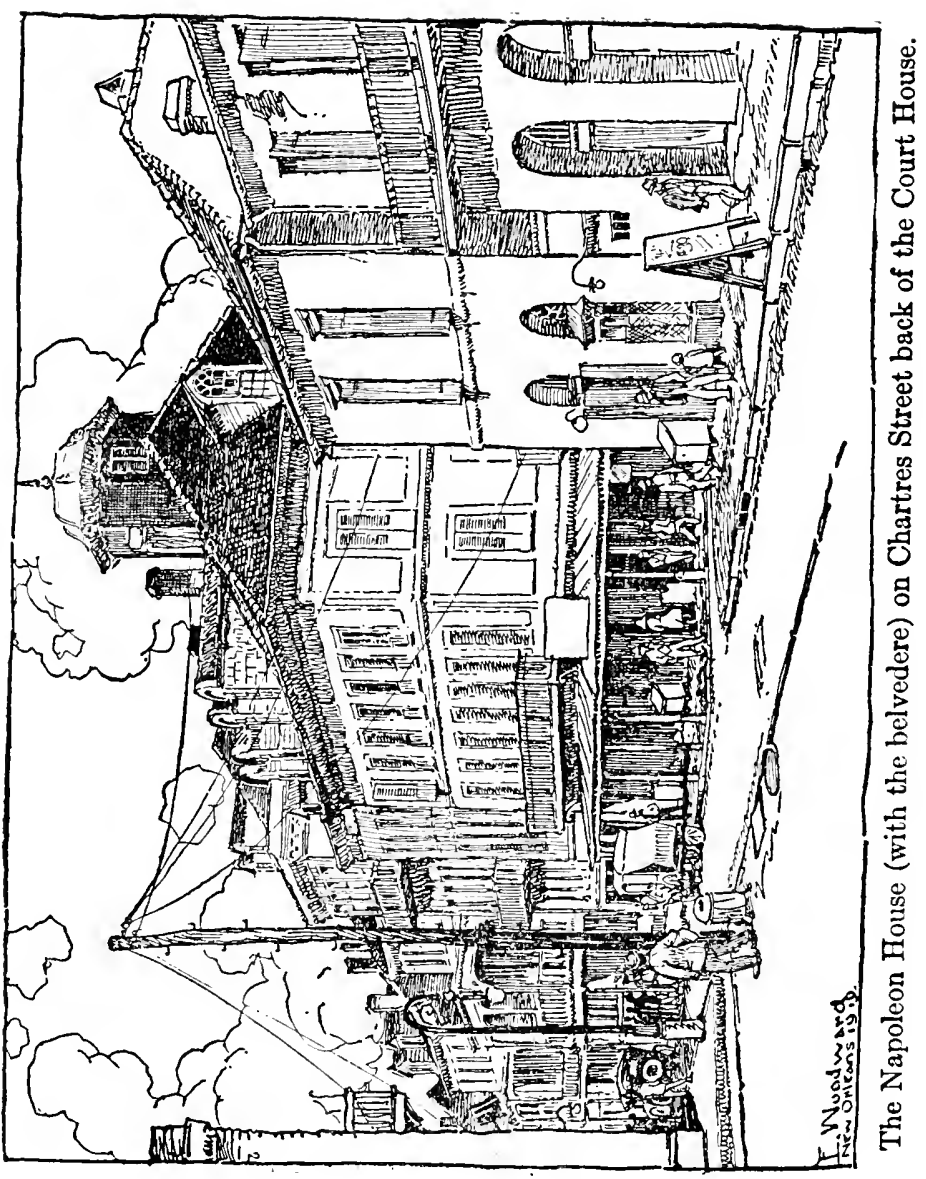



constituted in wordly eyes the perfection of the union became its destruction, twenty years after its consummation. From its beginning the contract drawn with so much business sagacity became a casus belli. Lawsuits ensued - the veil of family secrecy was rent in twain, because, in truth, the one thing needful, in marriage, which the contract had ignored, was lacking.

Micaela made a dash to Louisiana in 1831 to secure the succession of her mother and, if possible, a divorce from her husband; but a timely intervention from the Minister of Foreign Affairs, Sebastiani, frustrated this last. She returned by way of the great cities of the North and the Falls of Niagara, describing them to her aunt, Madame de Chalmette, in letters written with all the exuberance of a strong, original mind. On her return to Paris she obtained her independence of her husband and his family.

The culmination of the greatest Louisiana matrimonial union was a tragedy, that has bowed the fine old name of Pontalba under a veil of crape. It is a family secret of New Orleans, guarded with filial piety; the details are imparted by those who know them under the seal of personal confidence; the ghastly truth only is acknowledged, which isthat at Mont l'Evêque, on an October morning in 1834, Madame de Pontalba was discovered on the floor of her apartment, weltering in her blood, and apparently in a dying condition, her body torn with pistol shots. The old Baron was found dead, sitting upright in a great armchair in his apartment, a pistol in his hand!

Thus, in a moment of insanity, in his eightieth year, passed away the fine soldier of Bienville, the 
dashing Indian fighter, the noble aristocrat, the devoted husband, the too-doting father, the writer of charming letters, the author of the masterly "Memoir of Louisiana!"

By a miracle, Madame de Pontalba recovered, carrying to her death the bullets in her body and maintaining to the end the prestige of her wealth, position, and indomitable will. Still frequenting and frequented by the Faubourg St. Germain, she escaped none of the horror and excitement that filled the minds of the Ancien Régime, when it became rumored that the beautiful palace built by Louis XIV for the Duc de Maine, on the rue de Lille, was to be bought by the "Bande Noire" and razed to the ground-the site to be filled with smaller buildings. With her Louisiana millions she bought the palace herself, and even attempted, with the vaulting pride of woman, to live in it. Only royal wealth and attendance could, however, properly fill the place-four hundred rooms it contained, so the new proprietor, submitting, as even royal personages must, to circumstances, demolished the palace herself, but reserved all its artistic wealth of carvings, columns, ornaments and marbles for the new hôtel she built; a hôtel of magnificent state but more in proportion to her position and means. It was sold afterwards for five million francs to one of the Rothschilds.

Celestin de Pontalba came but once to New Orleans, on a business visit. His mother came twice, once as we have seen before the tragedy in 1831, and once later, when she received a warm welcome from 
her friends and relatives; ardent sympathizers in her griefs and misfortunes.*

Finding her native city in full tide of prosperity and architectural development, she was too much the daughter of her father not to want to connect her name with that of New Orleans. In 1846, through her agent, she communicated to the Council of the Municipality her desire to aid in the embellishment of her native city, proposing to demolish the two rows of buildings fronting on the Place d'Armes from Chartres and Condé (lower Chartres) Streets to the levee, and to replace these buildings by edifices according to a plan submitted to the Council. But with an astuteness worthy of her father, she would consent to carry out the project only if seconded by the Council, making the request that the new edifices be exempt from city taxation for twenty years from the date of their completion. The Council consented, providing that the entire front of said structures, in St. Peter's and St. Anne Streets, should be finished in all particulars according to the plans furnished.

In 1849, Madame de Pontalba communicated to the Council that, relying upon their resolution, she had contracted for the demolition and reconstruction proposed; the Council, on the excuse of some flaw in the contract, claimed that they were without authority to grant her the exemption asked for. Notwithstanding this, with characteristic energy, she persisted in her filial and patriotic purpose. Her plans grew in beauty and grandeur and finally found

* "Jackson Square," Henry Renshaw, Louisiana Historical Society. Quarterly, Vol. II, No. 1. 
consummation in the stately rows of buildings that stand on the northern and southern sides of the Place d'Armes. They were finished in 1850 and from the standpoint of to-day, even with the wear and tear of three-quarters of a century, to quote from the last pretty compliment paid them: "They are fair to look upon and they arouse admiration by their noble proportions, their spacious verandas and elegance of the tendril-like iron work, which displays the interlaced initials of the families of Almonaster and Pontalba."

All guides of New Orleans relate with proud pleasure that the central house of the row was finished in time to be furnished and offered to Jenny Lind as a residence when she came to the city in 1850. The celebrated chef and culinary authority of the time, Boudro, was engaged for the cuisine; it is also said that the Diva ever afterwards, in speaking of her visit to the city, mentioned him as the greatest attraction she had found in it. But the houses were entirely out of keeping with their old setting of the Place d'Armes, which still retained its rustic appearance of a village muster green, with grass-grown spaces enclosed within a dilapidated iron railing. Its only beauty consisted of its double avenue of old sycamores, the favorite promenade and the delight of the old citizens, who were fond of passing the summer afternoons under their shade, while enjoying the fresh breezes from the river.

It was from the Square that the evening gun was fired which gave the signal for slaves to retire from the streets; here it was that O'Reilly had proclaimed the sovereignty of Spain, and Laussat later the domination of the French Republic. And grass 
grown and shabby as it was, more gloriously still it was the scene of the cession of Louisiana to the United States. From its flagstaff, the fleur-de-lis the banner of Spain, the tricolor, had all risen in temporary sovereignty, until the flag of the United States arose and spread its folds to the wind, in sign of proud, permanent possession.

General Jackson passed in triumph through it to the Cathedral after his glorious victory of Chalmette. Nevertheless it had to submit to the spirit (the ruthless spirit, as it seems) of improvement. Its venerable sycamores were felled, despite the agonized protests of the citizens; its rough greensward was laid off in parterres. A flower garden was made of it, and a clean sweep (as it were) was made of its old memories and traditions, by changing its name and consecrating it to the memory of the hero of Chalmette.

When Madame de Pontalba left New Orleans in 1851, she carried with her the consciousness of having left, even as her father had done, an enduring mark upon her native city. In addition to a considerable contribution to the erection of the monument to Jackson, for whom she had an enthusiastic admiration, she had furnished a suitable site for it (a nobler one could not have been found in the United States), and she had added grandly to her father's benefactions-the Cathedral, the Cabildo and the Presbytère, by giving them noble and worthy surroundings, assuring beyond peradventure against the neglect and decay that have degraded many an historic and ecclesiastic center in Europe. For a half century the Pontalba buildings furnished the dwellings of the most exclusive families in the city. Jackson 
Square still reigns, the center of all civic, social and ecclesiastical functions of ceremony; the noble monument in its center, far from excluding, seems courteously to salute the old traditions and memories which seem to follow the great General as he guides his charger toward the Cathedral portal.

Micaela returned to her life in Paris and reigned there in a kind of exotic supremacy; giving her great entertainments and welcoming to them right cordially friends and relatives from her native place.

Charles Gayarré,* a kinsman and friend, used to relate that in 1837 he once had taken dinner with her on the evening of a great ball she was giving, to be preceded by a concert of artists from the Italian opera. The repast was luxurious in every particular, with many guests; among them were Celestin, her husband, with whom she was more friendly, and her three grown sons. She presided in a magnificent toilette and was taking the lead, as usual, in conversation, when she suddenly turned ghastly pale and fell back in her chair unconscious. Her sons at once calmed the guests, and carried their mother to a couch, explaining simply that she often suffered such attacks. They were the result of the wounds inflicted by her father-in-law. The banquet, the concert and the ball proceeded as if nothing had happened.

Charles Gayarré described her as majestic and impressive, and with the kindest possible expression of countenance, particularly when speaking to or about people from her old home. She died in 1874, in her hôtel, rue St. Honoré. Her husband survived

* Related also to the author. 
her four years, dying in 1878, at the age of ninetyseven, in his domicile, Avenue Malakoff.

Celestin de Pontalba, the eldest son and eventual bearer of the title, like his father came to New Orleans for his wife. He married, in 1858, Françoise Georgine Blanche Ogden who, like himself, belonged to a historic family of New Orleans. Her mother was the daughter of Madame de McNamara, who was a daughter of Chauvin des Islets de Léry and Charlotte Faucon du Manoir. McNamara was an Irishman (his title of Count has never been explained) who came to Louisiana early in 1800 to become a planter. Mérieult was the name of his plantation (below the city), from the name of its former owner.

The marriage of Celestin to Blanche Ogden, as she was familiarly called, was one of the pretty memories that survived to an old lady, a very grande dame of the past.* She was one of the little girls who clustered on the steps of the Cathedral to see the bride (a beautiful blonde) walk in, as was the custom of that time, at the head of a long suite of beautiful bridesmaids.

And, $\grave{a}$ propos of the beautiful blonde bride, comes to memory another story-a tradition. Madame McNamara Mérieult, sojourning in Paris during the Empire, was noted for her beauty, which was enhanced by a wonderful chevelure, golden blonde, that fell like a veil to her feet. Napoleon, so the fantastic story goes, who was at that time wishing to please the Sultan of Turkey, heard that that royal personage was looking through Paris for a

* Mrs. James Grimshaw; a Miss Berthoud, daughter of a dame d'honneur of Marie Antoinette. 
blonde péruque to take away with him to fulfill a promise to a favorite of his harem, and that he was in despair at not finding one suitably handsome. From maid to maid and from coiffeur to coiffeur the story went and traveled upward until it reached the ears of Josephine that the Louisiana Countess, McNamara de Mérieult, carried on her head the making of the most beautiful and wonderful péruque in the world! To Napoleon this was sufficient; Madame McNamara de Mérieult was approached and offered her own terms for her hair! She declined. And the story goes no further.

Celestin de Pontalba and Blanche Ogden left two sons and a daughter. The eldest son, Baron Edouard de Pontalba, brings the family well within the present memory of Louisianians. He was born in France in 1839, and in 1864 married, at Senlis, Désirée Victoire Clothilde de Vernois, the handsome aristocratic grande dame, who presided with the ineffable grace (one may say, of a Louisianian) at his table; showing herself in sympathy, talk and historical interests his coadjutor as well as helpmeet.

In heart and mind, true to ancestral attachments, Edouard de Pontalba ever responded to the name of the State as to a watchword; and fortunate was the one able thus to invoke his kindly interest and enjoy his unforgetable generosity of mind and hospitality of board. He was an ardent student of Louisiana history to which, as we have seen, he was connected by family ties, reaching through ancestral alliances to Bienville himself. Through his long and careful searchings for historical documents connected with Louisiana, he became an intimate frequenter of the colonial archives of France, prov- 
ing an ever-ready and available means of communication between them and Louisiana historical students.

In the progress of further elucidation of political questions and personal appreciations, he penetrated into the family archives of Mont l'Evêque, where finding the letters (from which we have quoted) of his distinguished and unfortunate great-grandfather, written to his wife, that throw such a kindly light upon his character, he copied and presented them to the Louisiana Historical Society. It is in his own minute, beautiful handwriting that we possess also the Etat des Services of the gallant soldier, which, with the letters, he presented to the Historical Society. He added also to its archives from his family papers the very valuable copies of the official letters of his great-granduncle, Governor Miro; an inestimable aid to the understanding of the important period of the Spanish Domination in Louisiana.

Slight of form, with extreme delicacy of features, modest and retiring to an almost embarrassing degree, he nevertheless conveyed the impression of an heir and, if need be, of an actor oi heroic deeds. He was a good talker in spite of his reserve, drawing frankly upon the inexhaustible treasures of experience, reading and family traditions at his command.

After passing through the war of 1870 , and the horrors of the Commune, he, in his old age and feeble health, was summoned to suffer the even greater horror of the late war! In Paris, in 1914, he endured the painful anxieties caused by the ruthless march of the Prussians upon it, and the terrible panic that, as a whirlwind, drove him and his family 
into flight from the capital. When he returned he was broken in health. His beautiful summer home at Senlis lay in the path of the Prussian army. He did not live to see the compensation of victory. $\mathrm{He}$ died during the early winter of 1919 in Paris, at the home of his daughter, rue Pergolese 66, and was buried at Senlis.

His only child, Blanche Genevieve Jeanne Micaela Delfau de Pontalba, is the wife of Jacques Frédéric Kulp of Paris. Their daughters, Jacqueline and Désirée, are the only descendants of this line of the Pontalbas.

Jacqueline is the wife of the Comte Roland Balmy d'Avricourt. The title and the patrimonial château of Mont l'Evêque passed to a half brother of the Baron Edouard, whose grandson Alfred is the only male descendant of the family living to-day. 


\section{CHAPTER VII}

\section{ROUER DE VILLERAY}

THE name of Villeré shines with a luster all its 1 own in the annals of New Orleans' history. To the historian the hand of the city seems to hold it poised aloft-a jewel from her casket. The name was known at first as Rouer de Villeray and, according to local tradition, was originally Italian, belonging to the illustrious house of la Rovere, which gave two Popes besides Cardinals and Bishops to the Church, many sovereign Princes to Italy and the Republic of Genoa, and possessed chevaliers innumerable of the most distinguished orders of France. $\dagger$

When the family became French is not recorded, but it is known that branches established in Piedmont passed from there into France in the sixteenth century, where they were known under the several names of Rovere, La Rouyer, Rouer.

One of them, Raymond de Rouer of Languedoc, a Knight of St. Louis and Governor of Narbonne, was sent as Ambassador to Spain in the sixteenth century, and in 1562 he commanded the armies of the King during the religious wars in Languedoc.

Louis Rouer de Villerày, the first of the name who

* "Familles de la France Coloniale." Margry. Paris, 1851.

$\dagger$ There are no documents left in the family for the reason that when, in Havre, in 1793, the wife of the Marquis de Villeré, a loyalist and émigrée, dreading a domiciliary visit from the Revolutionists, destroyed all her family papers, fearing that their discovery might lead to her husband's denunciation and condemnation. 
went to Canada, belonged to the branch of the family established in Touraine, the head of which, Rene de Rouer, bore the hereditary title of Marquis de Villerày, Seigneur of Martin, Révillon and of Comblot, near Mortagne, where he died.

Louis Rouer went to Canada about 1650, very young and very poor, to seek his fortune, following the good old Norman recommendation, "cherche qui n'a." The young Canadian sought; but found at first only dangers innumerable and cruel hardships of all kinds. Nevertheless, he was able to make his way despite them all, and from a subordinate employment rose at the age of twenty-four to a respectable position in the Sovereign Council of Canada, later becoming its President, a position that he filled for thirty years.

He married Catherine Sevestre, daughter of one of the great pioneer Canadian families, his name being now corrupted by the Canadians into Roy de Villeré. His sons following in the career he had opened for them in civil life, became Councillors and Judges. They married into good Canadian families, such as Le Gardeur de Tilly, de Repentigny, de Léry and Lemoyne de Longueil. They passed, or, as it was regarded in that day, mounted from the magistracy into military service. At the end of the Seven Years' War, four Villerés were listed in the French Army as officers. Upon the surrender of Canada by the French, they returned to France.

Previous to this, however, a Villeré had made his appearance in Louisiana. He had presumably, with the Canadian Chauvin family, to which he was allied by marriage, joined Iberville's expedition for the discovery of the Mississippi. It will be 
remembered that Iberville, in his preparations for his expedition, demanded that a contingent of Canadians should be allowed him.

The existing marriage contracts furnish the only traces by which this Villeré can be followed. In 1695, Jacques Nepveu, son of Philippe Nepveu and Marie Denise Sevestre, was married in Montreal to Michelle Chauvin, daughter of Pierre Chauvin and Marie Antreuil-a dispensation being obtained on account of their consanguinity. Marie Catherine Nepveu, their daughter, was married in Montreal to Etienne Roy de Villeré, the first Louisiana Villeré. He became the father of Joseph Roy de Villeré.

Coming to our next stepping stone of date, in 1726, we find living on Bienville's land, extending from New Orleans up the Tchoupitoulas road, "Le Roy, his wife, and Bellair, his associate." Higher up the river, on the Tchoupitoulas tract in Bienville's concession, were situated the plantations of the three Chauvin brothers: DeLery, Beaulieu and Lafrénière.

In 1728 the marriage was celebrated, in the St. Louis Cathedral, of Catherine Nepveu, widow of the deceased Etienne Roy de Villeré, and Jacques Hubert Bellair, son of Ignace Hubert and Barbe Chauvin. Here also, a dispensation, on account of consanguinity, was necessary, both parties being children of sisters.

Joseph Roy Villeré, who was very young when his father died, was reared by his stepfather, Bellair, who sent him to France, where he and his cousin, Nicolas de Lafrénière, received their education. The daughter of Hubert Bellair and Catherine Nepveu, Marie Marguerite Bellair, was married to her 
cousin, Nicolas de Lafrénière, who thus became the brother-in-law as well as cousin of Villeré. When Lafrénière was appointed Attorney-General, Villeré was named to the official post of Ecrivain de la Marine (maritime notary).

Beyond these facts nothing is known of the early life of Villeré. The great Canadian pioneers, leaving no private papers or documents behind them, have to be trailed, as it were, across a virgin forest of history, through which they glided like Indians. We come, however, into a clear space in the marriage contract between Villeré, described as an "Ecrivain de la Marine en cette ville," and Mademoiselle Marguerite de la Chaise, grandaughter of the Chevalier d'Arensbourg. The settlements were handsome and generous from both parties, as beseemed so notable a marriage. The dower of the bride amounted to forty thousand livres, the groom presenting her with six thousand. According to the good old Creole custom, the parents of the bride provided all the furniture, silver and linen of the future establishment, but with the stipulation, also a Creole custom, that the husband and wife should live with the bride's parents for the space of three whole consecutive years. The marriage was solemnized in the St. Louis Cathedral October 12th, 1759.

In 1763, Marie de la Chaise, sister of Marguérite, was married to François Chauvin de Léry-the first cousin of Villeré-thus binding the two great families together by another tie.

By 1763, Villeré had acquired a plantation on the Côte des Allemands and had become Captain of the German Militia, of which his wife's grandfather, the old Chevalier d'Arensbourg, was Commandant. 
At the end of the prescribed three years, the couple established themselves on their plantation. As described by Gayarré, it was not a large plantation, and the slaves upon it, of both sexes and all ages, did not exceed thirty-two. The house was the usual modest Louisiana plantation house of the period, one of the little unpainted wooden cottages, called at that time "Acadian houses," furnished with the Spartan simplicity which, Gayarré remarks, distinguished the Louisiana planters of that time. The furniture of the wife of the most distinguished citizen of Louisiana and granddaughter of the Sieur de la Chaise, consisted of a cypress bedstead, three feet wide by six feet in length, with a mattress of corn shucks and one of feathers on top; a bolster of corn shucks, and a coarse cotton counterpane, spun and woven probably by the lady herself; six chairs with straw bottoms; and candelabra with the common wax candles made in the country. The rest of the house was not more luxuriously furnished. Here, in 1761, was born to them their son, Jacques Philippe Roy de Villeré, who became the first Creole Governor of Louisiana and, in 1764, their daughter Louise, who married Simon Du Courneau Dasplatia, and here they ended their serene lives of wedded bliss.

In June, 1764, the news came of the cession of Louisiana by France to Spain. It was the hardy, independent Canadians who were the first to resent the transaction as an insult to Louisiana and to themselves. Always restive under the official arrogance of the French officers, civil and military, they had with their own arrogance shouldered their way to the front in opinion and action, assuming a pro- 
prietary right of domination in the community founded by Canadians, and maintained by their independent strength and shrewdness, in striking contrast to the more dependent position of the French.

Lafrénière, the foremost citizen among the Canadians, had risen to the important position of Attorney-General, a position that he owed to his natural abilities and superior education. Backed by his strong family connections and by his ever-growing popularity, he, and not Aubry, was unquestionably the first representative of power in the Louisiana country. When he voiced a manly opposition to slavish submission to a decree that, by the stroke of a pen, passed them, their families, their children and their posterity away to another foreign country, Aubry's voice, in comparison, was a mere whimpering of childish fear.

When Lafrénière called a public meeting in New Orleans to protest against the cession of the province to Spain, Villeré attended it, seconding him enthusiastically and whole-heartedly, and leading the applause of the Assembly for Lafrénière. When the Assembly was again called to support the resolution for the expulsion of Ulloa, Villeré, at the head of four hundred armed Germans, marched down the river, captured the Tchoupitoulas Gate, entered the city and proceeded to the place of meeting, where he again supported Lafrénierè's resolution. His services can be measured by the furious denunciations of the Spanish Attorney-General. Lafrénière, alone, has the glory of surpassing Villeré in the celebrated "presentment":

"With regard to Villere," so it says, "he was a man of atrocious 


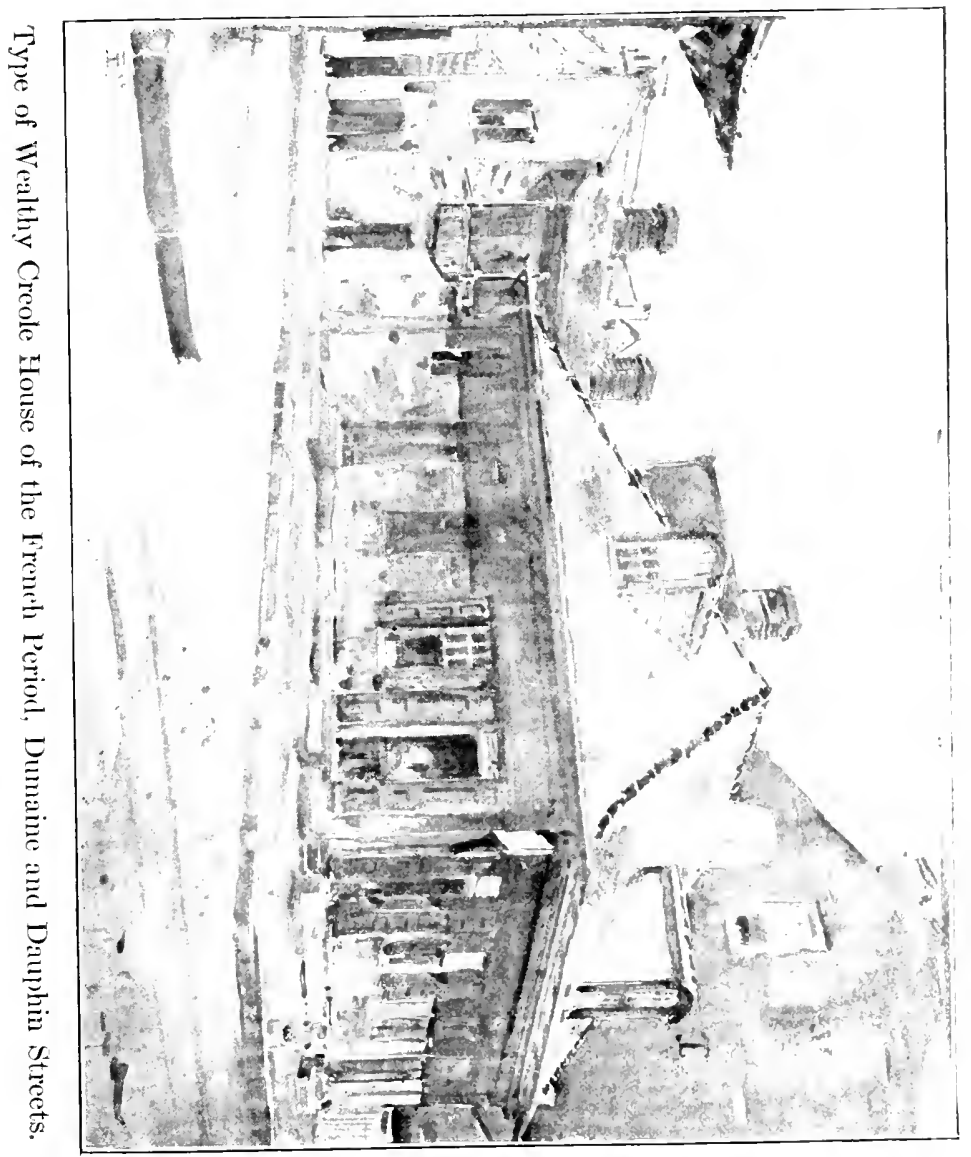



disposition and remarkable for his pride and violence; he was undoubtedly one of the most conspicuous movers in the conspiracy, and signalized himself by deeds of the most striking character. He it was who stirred up to rebellion the Germans, of whom he was the commander. He it was who made them sign the petition requesting the expulsion of Ulloa and of other Spaniards. He it was who led them to New Orleans to incorporate them with the other rebels and to strengthen the insurrection . . . he was at their head and commanded them." . . .

Upon the arrival of O'Reilly, Villeré at first thought of seeking safety with the English at their post a few miles above his plantation. But when he heard of the arrest of his friends and kinsmen as conspirators, receiving at the same time assurances from Aubry that O'Reilly was minded to act leniently toward all engaged in the revolt, he decided to proceed instead to New Orleans and present himself to the Spanish General.

$\mathrm{He}$ was arrested at the Tchoupitoulas Gate. There are various versions of what befell him. The Spanish official report states that the blasting of his hopes threw him into such a state of frenzy that he died, raving mad, on the day of his arrest.*

The cool and judicial Martin, who lived at a time when intimate evidence of the affair was obtainable, relates that after Villeré was arrested he was immediately conveyed to a Spanish frigate which lay in the river. On hearing of this, his wife hastened to the frigate in a skiff rowed by her slaves. As her boat approached the vessel, she was hailed and roughly ordered away. She made herself known and solicited admission to her husband, but she was answered that she could not see him. Villeré, in the place of his confinement, recognized his wife's

" Gayarrés "French Domination." 
voice in protestation, and insisted on being allowed to see her. On the refusal of this, a struggle ensued between him and his guards, in which he fell, pierced by their bayonets.

"His bloody shirt, thrown into the boat, announced to Madame Villeré that she had ceased to be a wife; and the rope was cut that held the skiff to the frigate." Gayarre thinks that the atrocity of the bloody shirt is not probable; but the story is piously preserved in popular tradition, and has been repeated by other historians as well authenticated as Martin.

Villeré's escape from the Spanish tribunal did not relieve him from the condemnation he had deserved, according to the Spanish Attorney-General. As the others had been condemned to death, in the same manner, his memory was condemned as infamous. The death of Villeré, however, in New Orleans, excited even more horror than the subsequent execution of Lafrénière. A contemporary historian, Champigny, has written what must have been the popular feeling about him:

"None could be braver than Villeré . . . he had everything; valor, fortitude, freedom of mind. Violent and fiery, but frank, loyal, and firm in his resolutions; of good size, well made, his step firm, his look bold and martial, his devotion to his King was a frenzy rather than a form of patriotism. . . . Had all the colonists thought as he did, I doubt whether a single Spaniard would ever have reached New Orleans."

The machinery of the Spanish Government was installed and set in motion. The great French Colonial tribunal, the Superior Council, was abolished, and in its place the Cabildo was inaugurated, with Alfarez, Alguazil, Alcalde and Regidores. Spanish was made the official language, not only in 
the State, but in the Church. Spanish priests were put in the Cathedral. The Ursuline Nuns were required to use Spanish breviaries and to teach Spanish. De jure and de facto, the province was made the province of Spain, as surely as it had formerly been the province of France.

After O'Reilly's departure, Don Luis de Unzaga became Governor. A great silence and quietude fell over the Creole population. The excitement of the revolution, like a delirium of fever, passed away in the gradual restoration of healthy activities-save in the hearts of those families where was cherished and enshrined the bloody grave of a father or husband. Time and the gentle conduct of the Spanish Government slowly effaced the traces of the past. The brother of Marguérite de la Chaise, and brotherin-law of Villeré, accepted a position in the Cabildo. In an incredibly short space of time we read of social amenities and cordialities between the Spaniards and the Creoles, with the usual happy result of intermarriage. Unzaga, himself, set the example by marrying the daughter of St. Maxent, a wealthy Creole planter; other officers imitated him. Milhet's widow married Don Panis, Captain of the firing squadron that executed the patriots, but it is said that she never found this out, so well did he guard his secret. Creole names crept into official positions. A Louisiana regiment, to serve the Spanish King, was formed from the élite of the population. "It is an admitted fact," writes Gayarré, "that the Creoles of those days were remarkable for their great size, for the manliness of their bearing, for their peculiarly striking lineaments, which constituted nobility of face, and for the elegant symmetry of their forms." 
O'Reilly, struck by the distinction in appearance of the Creole officers, regretted his inability to take with him some of them to show the King as speciments of his new subjects.

Of all the documents that the historian longs for at this period, the one whose loss or non-existence is most deplored is one that might have recorded the life of Jacques Philippe Villeré, the son of Joseph Roy Villeré, the first Creole Governor of Louisiana: Imagination alone can supply it, and we turn fondly to the picture of the little boy of eight in the planta. tion home, anxiously watching his father in deliberation, hesitating between the advice of his wife not to trust the Spaniards but to escape to the English, and the advice of Governor Aubry, in a written letter counseling a manly confidence in O'Reilly's fine words and gracious demeanor. The child sees and hears the proud decision; the final determination to brave rather than to flee from the Spaniards; to take his stand beside his imprisoned friends. With beating heart he looks on as his father makes ready to depart, and with his mother he receives his embrace.

Then in the quiet of the apprehensive household, comes the rumor-forerunner of the dire truth of the master's, the father's, the husband's arrest and capture! Then the little boy beholds his mother's consternation and frenzied haste to go at once to join her husband-to share his fate with him! No time now for farewells! She throws herself into the skiff, always waiting at the plantation landing on the river, and her slaves, the good rowers, bend their backs and strain their muscles under her urging for greater and greater speed-and so they disappear around the bend in the river. Anxious long hours of 
waiting follow for the little boy-she returns, clasping a reddened garment to her bosom! No cries! No words! They are not needed, and then the black doom hovering like a cloud over the city for days, crashes, falls! To the eyes on that plantation, it must have been a surprise that annihilation of the city itself did not ensure, that its buildings still could be seen standing!

The seizure of the plantation by the Spanish officials followed, and the flight of the widow and her two children (although this is not known) to a refuge with the grandfather, the old Chevalier d'Arensbourg, the patriarch of the German Coast. The rightful inheritance of wealth was succeeded by an inheritance of poverty! But after this comes a tardy gesture of pity and sympathy from France. King Louis XVI sends for the son of Joseph Roy Villeré, to be educated at his court, at his expense. The little boy departs for France, and his career is now recorded for us.

Schooled and trained like the son of a nobleman, he became a page in the Court of the King. But, according to a story inherited by his great-grandchildren, and still repeated, the life at court had its trials for the little Creole, fresh from a Louisiana plantation. His vernacular was the Creole patois of his negro nurse. When excited or angry he forgot his French and, in local parlance, talked "nigger," to the extreme delight and amusement of his fellow pages. His feet, as awkward as his tongue, could never learn to walk on waxed floors; he slipped and fell continually, an accident that never failed to excite further ridicule. One day when the laughter at his expense was at its height, the young Creole, with a 
vigorous expression or two of "nigger," jerked off his coat and, proceeding to show the little courtiers what he could do with his fists, gave each one a severe drubbing, and suffered no more from their ridicule.

At eighteen, Villeré was commissioned a Lieutenant in the French Army, the King presenting him with a sword. He joined a regiment serving in San Domingo. A few years later, on the death of his mother, he returned to his own people in Louisiana; and in 1784, in the parish church of St. Louis, he was married to Henriette Fazende, daughter of Gabriel Fazende, who came from France in 1723 to serve on the first Superior Council in the colony. They made their home on a sugar plantation below the city, facing the river and adjoining the estates of Delaronde, Chalmette and Bienvenu. The land of these plantations, gained, as we shall see, immortality in history as the battlefield upon which General Jackson defeated the British Army under Pakenham, in 1815 .

The home of Villeré was a wooden cottage similar to the one in which he was born, all the rooms being on one floor, with wide galleries in front and rear, surrounded by trees and shrubberies.

Five children were born to him: René Gabriel, 1785; Adele, 1792; Jules, 1794; Delphin, 1797; Caliste, 1799; Félix, 1802; Anatole, 1807.

There are no other happenings to record in the life of the sugar planter. His was the life that his father had dreamed of, on his plantation, with his wife and children. The passing of the seasons, the ripening of his crop of cane, the growth of the children from babyhood to childhood, filled the years, a scant number as history reckons it, when lo, by a 
mere grasp of the hand, Napoleon seized from Spain and returned to France the colony so carelessly thrown away in 1763-the country which thirty-four years before his father and uncle had given their lives to preserve to France!

Villeré could watch from the gallery of his plantation house the Colonial Préfêt, Laussat, going up the river on his way to take possession of the city, his barge followed by a long procession of boats, filled with Spanish officials and Creole citizens. $\mathrm{He}$ doubtless contributed by his presence to the brilliant fêtes given in the city to celebrate the great event. But his name does not appear in any of the addresses to the French Préfêt printed by the exuberant Creoles.

Laussat, nevertheless, was too well informed to ignore Villeré's importance in the community. He writes in his report to his government on the measures he took to annul the Spanish municipality and inaugurate a French one in its place, announcing that after selecting M. Boré for Mayor, he took care to join with him, in authority, some of the most respectable inhabitants of the city, known to have a capacity for business and a knowledge of the three languages spoken in the colony-French, Spanish, English.

"It was with a true feeling of pleasure," he writes, "that I put in authority M. Villeré, the son of the most interesting of O'Reilly's victims, himself much loved in the colony and held in repute for his probity, good conduct and merit. I thus discharged a second debt on the part of France."

In the more impressive ceremonies shortly afterwards, of the transfer of Louisiana to the United States, Villeré acted as Major on the staff of Laus- 
sat. He became, with the colony, American, and served his new flag with steady-going loyalty.

To the new American Governor's many anxieties, to the many causes of perturbation that were spread like thorns on the couch of that serious, conscientious official, to his patient complaints to President Jefferson and Secretary Monroe, Villeré furnished naught. When Louisiana from its state of probation was finally raised to the dignity of a State in the Union, he was chosen as a member of the convention called for the momentous duty of framing a constitution-the first constitution of Louisiana (1812). The record of his contributions to its proceedings is contained in the report of the Convention.

Three years later came the great, the crowning ordeal to the new State. In 1815, the English Army invaded Louisiana, counting upon finding a divided State through the ill feeling of the Creoles to the American Government, and an easy and sure conquest of New Orleans. But the annals of military history do not contain a more striking example of miscalculation than the simple story of what ensued. It is too well known to repeat except in connection with Villeré. Offering himself at once to Governor Claiborne, he was made Major-General of the first Regiment of Louisiana Militia, and given a commission at one of the outposts of defense of the city.

The English plan of campaign was to secure a position on the river, whence they could strike at New Orleans before it had time to prepare adequate means of defense. Through the treachery of some Spanish fishermen, they were led from the lake where their ships lay, through a bayou, to the 
Villeré plantation canal, in full view of the river. But the story should be told in its full completeness:

"At dawn the barges entered the bayou. The English sailors, standing to their oars, pushed their heavy loads through the tortuous shallow water. By nine o'clock the detachment was safe on shore. 'The place,' writes the English authority, an officer during the campaign, 'was as wild as it is possible to imagine. Gaze where we might, nothing could be seen exccpt a huge marsh covered with tall reeds. The marsh became gradually less and less continuous, being intersected by wide spots of firm ground; the reeds gave place by degrees to wood, the wood to enclosed fields.'

"The troops landed, formed into columns, and pushing after the guides and engineers began their march. The advance was slow and toilsome enough to such novices in swamping. But cypresses, palmettoes, cane brakes, vincs and mire were at last worried through; the sun began to brighten the ground and the front ranks, quickening their step, broke joyfully into an open field, near the expected canal. Beyond a distant orange grove, the buildings of the Villeré plantation could be seen. Advancing rapidly along the side of the canal, and under cover of the orange grove, a company gained the buildings, and, spreading out, surrounded them. The surprise was absolute. Major Gabriel Villeré and his brother, sitting on the front gallery of their residence, jumped from their chairs at the sight of the redcoats before them; their rush to the other side of the house only showed them that they were bagged!

"Secured in one of his own apartments, under guard of British soldiers, the young Creole officer found in his reflections the spur to a desperate attempt to save himself and his race from a suspicion of disloyalty to the United States, which, under the circumstances, might easily be directed against them by the Americans. Springing suddenly through his guards, and leaping from a window, he made a rush for the high fence that enclosed the yard, throwing down the soldiers in his way. He cleared the fence at a bound and ran across the open field that separated him from the forest. A shower of musket balls fell about him. 'Catch or kill him!' was shouted behind him. But the light, agile Creole, with the Creole hunter's training from infancy, was more than a match for his pursuers in such a race as that! He gained the woods, a swamp, while they were crossing the field, spreading out as they ran to shut him in. He sprang over the boggy earth into the swamp, until his fcet, sinking 
deeper and deeper, clogged and stuck. The Britons were gaining; had reached the swamp! He could hear them panting and blowing, and the orders which made his capture inevitable. There was but one chance; he sprang up a cypress tree, and strove for the thick moss and branches overhead. Half way up, he heard a whimpering below. It was the voice of his dog, his favorite setter, whining, fawning and looking up to him with all the pathos of brute fidelity. There was no choice; it was her life or his, perhaps the surprise and capture of the city! Dropping to the earth, he seized a billet of wood, and aimed one blow between the setter's devoted eyes-with tears in his own eyes, he used to relate. To throw the body to one side, snatch some brush over it, spring to the tree again, was the work of an instant. As he drew the moss around his crouching figure, and stilled his hard breathing, the British floundered past. When they abandoned their useless search, he slid from his covert, pushed through the swamp to the next plantation, and carried the alarm at full speed to the city!

"The British troops moved up the road along the levee to the upper line of the plantation, and took their position in three columns. Headquarters were established in the Villere residence, in the yard of which a small battery was thrown up. They were eight miles from the city and separated from it by fiftecn plantations, large and small. By pushing forward, General Keane in two hours could have reached the city, and the Battle of New Orleans would have taken place then and there; and most probably a different decision would have been wrested from victory. The British officers strongly urged this bold line of action, but Keane, believing the statement that General Jackson had an army of about fifteen thousand in New Orleans, a force double his own, feared being cut off from the fleet. $\mathrm{He}$, therefore, concluded to delay his advance until the other divisions came up. This was on the twenty-third day of December. 'Gentlemen,' said Jackson, to his aides and secretaries at half past one o'clock, when Villeré had finished his report, 'the British are below; we must fight them to-night.' "* . . .

In the skirmishes that followed, and in the great battle of the eighth of January, Joseph Roy Villeré fought gallantly and brilliantly, when (so it is always repeated in the family tradition) he wielded the

* "New Orleans, The Place and the People." Grace King. 
sword presented to him by Louis XVI. One of the trophies picked up from the field of battle was given to Villeré - a small, very pretty fowling-piece, said to have belonged to General Lambert. All the boys of the Villeré family learned to shoot upon it, calling it familiarly and tenderly "le petit Lambert." It is still a cherished heirloom in the family, having survived all the trials and tribulations possible to a gun during the Confederate War.

Pakenham, shot on the field of battle, was carried, dying or dead, to the Villeré house and there laid upon a bed in a front room. According to the slaves employed in the house, he was buried temporarily under a great pecan tree on the lawn; by the same token, the old slaves, more picturesquely than truthfully, aver the nuts from that tree, for years afterwards, always showed a red streak as of blood.

The Villeré house exists no longer, having been destroyed by fire, but its substitute, a low cottage with gallery in front, preserves a likeness of the home in which Villeré lived and to which the body of the gallant Pakenham was borne from the field of battle. The field would still be in sight, and the river, as in 1815 , but for what, after the memory of the battle, is the glory of the spot-an avenue of majestic oaks, veiled in their moss. ${ }^{*}$ The venerable trees did not belong to the Villeré house, but to Versailles, the mansion of the Marquis de la Ronde, whose driveway, leading from the river, they shaded and adorned. The good brick walls of the noble ruin, with ragged holes in their stucco, still strive to

* In the opinion of Mr. Charles S. Sargent, the supreme authority on trees in America, this avenue of oaks is probably "the finest in the United States" as he expressed it, in conversation with a friend. 
maintain their old air of patrician pride and strength. Time has despoiled the once elegant villa of its great front gallery, and its only roof is now the evergreen tops of tall trees, that have pushed their way up from the foundations to spread their covering leaves over it. The soft foliage of a thick undergrowth screens the desolation of the once lordly hall and drawing-room. A more beautiful, haunting place for memory cannot be imagined, when, under the low-lying sky, the long gray moss of the oaks swings, and vibrates in the breeze from the river. It is a spot of pious pilgrimage for historical devotees, a hallowed shrine frequented by strangers. Ladies of patriotic societies hold gatherings there on the anniversary of the battle and recapitulate to one another the traditions, the stories, the incidents that ladies love to collect from the past. A cemetery for soldiers, with its checkerboard of graves with painted headboards, fills the space (and hurts the eye), where once fought the heroic forces of England and America, and a tall, gaunt, bare monument tries, in vain, to commemorate the glory of the victory.

Poetry and imagination, however, have raised their own monument-not from granite but from living memory, to Jackson behind his embankment with his Tennesseeans, his Kentuckians, his Baratarians, and his Creoles having against them Pakenham with his hitherto unconquerable regiments, flaunting on banners their famous names. After the battle, it is said, they made a broad red line of uniforms on the ground where they fell, whole platoons together! And it is always remembered and repeated how, once the smoke of battle cleared away, 
the Angel of Peace came down to the ground where lay the dead with such blessing of good will as wiped all enmity from the heart of the living. For, as sings the oldest of poets of the most heroic of warriors: "These men fought for the sake of a heart-consuming contention. Yet did they part again after in friendship bonded together!"

(1) The Colonial Dames of Louisiana have exerted every possible effort of enthusiastic patriotism to obtain from Congress adequate provision for the preservation of this noble field, and its maintenance as a National Park. It is the fervent wish and prayer of all Louisianians that what they once preserved to the Union may, by the Union, be preserved to them, "To the glory of God and in memory of the glory achieved by men!"

(2) The Chalmette Tract, as it is called, is now the property of the Southern Railways System, which maintains there extensive docks, where ships arrive from all parts of the world, to discharge and receive cargoes.

To return from the fascinating divergencies of the history of Louisiana to the history of Villeré - after the Battle of New Orleans, he had one more adventure before him. In 1816, he was elected Governor of Louisiana to succeed Claiborne. Time has never awarded a more signal compensation for past injuries. His term fell during the halcyon days when Louisiana enjoyed, as our history records it, her Golden Age; when wealth flowed in a tidal wave over State and City, disrupting old limits and barriers and obliterating old landmarks; when, in truth, prosperity had to be contended with as adversity once had been.

The record of it is to be found in the pages of Gayarré and Martin. Villeré proved himself to be the Governor for the period; wise, steadfast, exalted in his ideals. His first messages are those of a Louisianian carried away by the good fortune that 
had come to his State, through admission to the Union. "May we always by our conduct render ourselves deserving of such blessings," is the ending of one of them. His last message comprehends not only Louisiana, but America:

"Wherever we turn an enquiring eye, it is impossible among the civilized nations of the earth to discover one whose situation we can reasonably envy. The most powerful are certainly much less free; the most free are less tranquil; the most tranquil less independent; and the most independent, less sheltered from foreign influence, than the great American family."

Villere died in 1830 and was buried in the St. Louis Cemetery, in a simple brick tomb that has almost sunk out of sight in the soft soil. His eight children survived him. The sons settled on plantations below the city on both sides of the river as near as possible to the paternal home; prettily named "Conseil" in memory of the good counsel that had never failed them there. It was the pleasant custom of the six brothers every morning, before beginning their day's work, to meet under a great tree on one of the plantations over the river, where they exchanged greetings and talked over the news of the day.

René Gabriel was married to Eulalie de la Rondes; they had five children. She was the daughter of Pierre Denis de la Ronde. Jules, married to Perle Olivier, had three children. The daughter of Jules Villeré and Perle Olivier became the wife of General Gustave Toutant Beauregard, and was the mother of his three children: René, Henri and Laure. Delphin, married to Delphine Bienvenu, had four children. Caliste, married to Isabel Duverger, had eight children. Hon. Paul Villeré, Vice President of the 
Hibernia Bank, is the grandson of Caliste Villeré and Isabel Duverger. St. Denis de Blanc Villeré, a noted citizen and the bearer of two famous names, is also the grandson of Caliste Villeré. His father was the well-known merchant, Ernest Villeré; his mother, Angèle Bernard. Felix married Eloise Verret and had six children. Anatole, married to Félicité Elmina Forstal, had six children. Adèle married Hugues de la Vergne; they had six children. Léocadie married, first, Cyril Fazende; second, Paul Lanusse.

Governor Villeré's eldest son, Major Réné Gabriel Villeré, died in 1855 on his plantation in the Parish of St. Bernard, in the same house, so it was stated, in which he had been taken prisoner by the British in 1815. To quote a mortuary notice which, in his case, was a true testimonial, he was "a noble representative of the virtues and high qualities of the ancient population." He was buried with military honors in the old St. Louis Cemetery.

With the sole exception of the Delery family, the descendants of the Chauvin brothers, the Villerés count more descendants in active business life in the city than any of the other "foundation families," as they may be called. Their name spreads like a fruitful vine over all the genealogical records of the old prominent Creole families.*

* The records of the Villeré family were kindly furnished the author by Madame Fernand Claiborne, herself a representative of the direct line of Joseph Roy Villeré. Her father was Alcée Villeré, her mother Delphine Fleitas, daughter of Paulin Fleitas and Celestine Jumonville de Villiers. She is married to Fernand Claiborne, Esq., grandson of Governor Claiborne. Their children are: Mademoiselle Clarisse Claiborne, and Lieutenant Omer Claiborne, in service in France (A. E. F.). 


\section{CHAPTER VIII}

\section{D'ARENSBOURG}

Charles FREDERICK D'ARENSBOURG arrived in Louisiana, landing at Biloxi in 1721, according to our best and indeed only authority about him.* He was a former Swedish officer from the town of Arensbourg on the Island of Oesel in the Bay of Riga which, with the whole province of Livonia, belonged to Sweden up to the year 1721, the date of Charles Frederick's emigration to Louisiana. As thirty Swedish officers are said to have accompanied him, as Deiler states, it may be assumed that as the cession of Livonia to Russia occurred in 1721, they all, having fought on the side of Sweden against Russia, preferred exile to Russification.

According to tradition among his descendants, d'Arensbourg fought at the Battle of Paltava, on the staff of Charles XII (1709), and fought so gallantly that the Swedish King presented him with his sword. On the surrender of the Swedes, the Russian General gallantly refused to take this sword from the young officer and he brought it out with him to Louisiana.

D'Arensbourg came to his new country with a commission, issued in Paris by the "Compagnie des Indes," shortly after the failure of the Mississippi scheme and Law's flight. He was given command of

* J. Hanno Deiler. "The Settlement of the German Coast of Louisiana." 
a large band of German settlers, awaiting embarkation in Havre for the Law concession on the Arkansas River. They sailed on the "Portefaix" and arrived in October at Biloxi, bringing with them the news of Law's failure, which caused great consternation among the new colonists.

The news traveled up to the Arkansas River, where a band of Germans were already settled; they, abandoning their lands and crops, took to their boats in a panic, and hastened to Biloxi, to demand immediate passage back to their fatherland. Stopping on the way at New Orleans, where Bienville was at work on his proposed city, he found means to pacify them and induce them to remain in the colony and join the fresh arrivals of their countrymen, under d'Arensbourg; changing the location of their settlement to the much more promising one of the rich alluvial lands on the banks of the Mississippi, about twenty miles above New Orleans (comprised to-day in the parishes of St. John Baptist and St. Charles).

It seems impossible to resist the temptation to give Hanno Deiler's moving description of what followed:

"No pen can describe, nor human fancy imagine, the hardships which the German pioneers of Louisiana suffered even after they had survived the perils of the sea and epidemics and starvation on the sands of Biloxi. No wonder that so many perished. Had they been of a less hardy race, not one of these families would have survived.

"It should be remembered that the land assigned to them was virgin forest in the heavy alluvial bottoms of the Mississippi, with their tremendous germinating powers awakened by a semi-tropical sun. Giant oaks with wide spreading arms and gray mossy beards stood there as if from eternity, and defied the axe of man. Between them arose towering pines with thick undergrowth, bushes and shrubs and an impenetrable twist of running, spinning, and elimbing 
vines under whose protection lurked a hell of hostile animals and savage men. Leopards, bears, panthers, wild cats, snakes and alligators; and their terrible allies, a scorching sun, the miasma rising from the disturbed virgin soil, and the floods of a mighty river-all these combined to destroy the work of man and man himself. There were no levees then, no protecting dams, and only too often when the spring floods came, caused by the simultaneous melting of the snow in the vast region of the upper course of the Mississippi and its tributaries, the colonists were driven to climb upon the roofs of their houses and up into trees, and hundreds of miles of fertile land were inundated. . . There is in Louisiana a popular saying -heard from Creoles when they speak of work uncommonly hard: 'It takes German people to do that.' "'

"Nevertheless, in spite of all the hardships which the pioneers had to endure and the difficulties to be encountered, German energy, industry and perseverance conquered all; and although hundreds perished, the survivors wrested from the soil not only a bare living but in the course of time a high degree of prosperity also. Early travellers who came down the Mississippi, describe the neat appearance of their little white houses which stood in endless numbers on both banks of the Mississippi, and they also tell how these thrifty Germans used to row down to New Orleans in their boats, with an abundance of their produce; vegetables, corn, rice, and, later, also indigo, to sell their goods on Sunday mornings in front of the Cathedral; and how at times when non-producing New Orleans in vain waited for provision ships from France or San Domingo, these German peasants more than once saved the eity from heavy famine."*

Charles Gayarré relates that one of the pleasures of his childhood was to stand on the levee in front of his grandfather's plantation above the city and watch of a Saturday afternoon the long procession of skiffs, from the Côte des Allemands, "heavily laden with vegetables, fruit, poultry and eggs, pass by on their way to New Orleans, which they supplied with farm produce."

"The "Côte des Allemands" was dubbed, in short," La Côte d'Or" of Louisiana. 
Laussat, in an official letter to the Minister of the Interior, Chaptal, June, 1803, adds this tribute of praise:

"What is called the 'German Coast' is the most industrious, the most populous, the most at ease, the most upright, the most respected part of the inhabitants of this colony."

D'Arensbourg obtained a concession among his German settlers, built his home and reared his family among them, sharing their joys and hardships. For forty years he served them as judge and commandant, taking creditable part in all the military activities of the colony, particularly in the defensive measures against the Indians after the Natchez massacre. He took a prominent stand against the giving over of the province by France to Spain. So competent an authority as Deiler says that "the revolution of 1768 against Ulloa began on the German Coast, and it was d'Arensbourg's word and his influence that enabled Villeré to march with four hundred Germans upon New Orleans and take the Tchoupitoulas Gate." After this, joined by the Acadians under Noyan and the Tchoupitoulas militia under de Léry, they marched to the Place d'Armes to support the demand of Lafrénière to give Ulloa three days' time to leave Louisiana.

Among the six revolutionists condemned to death by O'Reilly, two were married to granddaughters of d'Arensbourg. Tradition has it that O'Reilly intended also to have d'Arensbourg executed, but he was saved through the intercession of Forstall, under whose uncle O'Reilly had served in the Hibernian regiment in Spain. 
D'Arensbourg was made a Chevalier of St. Louis in 1763. He died in 1779, a patriarch of eighty-four, surrounded by his children and grandchildren, and the children and grandchildren of the German settlers that he had led to Louisiana when he was a young man of thirty-one.

He married, in the colony, Catherine Mextrine, according to Hanno Deiler, a daughter of one of the German settlers. The eldest son married Françoise de la Vergne; the second, Elizabeth Duclos de Selles. Pélagie married Jacques de la Chaise, son of the King's Commissary. A third daughter, whose first name is unknown, became Madame de "Bois Clair."

Of the Swedish officers who accompanied d'Arensbourg no trace remains in Louisiana history. In the course of centuries the Germans have been absorbed in the Creole population (as were the descendants of d'Arensbourg) and can only be traced in Louisiana records by the curious philologist who, like Hanno Deiler, cares to follow the windings and transmutations of these names, as they travel upward to bloom on the highest branches of local genealogical trees, attached to representatives of most prominent and important governmental and social personalities.

Of the fate of the famous Charles XII sword, the following story is told. The Chevalier was a model of virtuous dignity and of the most perfect moral rectitude, giving an example to his eldest son which was not followed. Before his father's death, the bearer of his name and title asked for the sword, claiming it as his by right. The stern old Swede took it, and, standing up, broke it across his knee, handing the fragments to his son with the words: "You are not worthy to wear it!" 


\section{CHAPTER IX}

\section{DE LA CHAISE}

TACQUES DE LA CHAISE left behind him to Louisiana the traditions of an interesting and most impressive personality, joined to the reputation of a perfect official or representative type of the old French magistracy. He was one of the two commissioners sent to Louisiana by the Company of the Indies in 1722, charged with inquisitorial powers to take information on the conduct of all the officers and administrators of the colony, and to make a report to the government. The brother commissioner, de Saunoy, dying shortly afterwards, de la Chaise remained invested with the full power of the joint commission. He met, as was to be expected, fierce opposition in the colony, but proceeded unflinchingly in the discharge of his duties.

Gayarré, evidently speaking from intimate knowledge, calls him "one of the worthiest men the colony ever possessed," giving the following description of him:

"He was of patrician birth, a nephew of the confessor of Louis XIV. The Château d'Aix, the feudal castle of the family, was situated in the Province of Forez. His father was the son of George d'Aix, Seigneur de la Chaise, who married Rénce de Rochefort, daughter of one of the noblest houses of France. Members of the family distinguished themselves in the army of France. In the time of the Regency one of them died, a Lieutenant-General, leaving a reputation for uncompromising integrity and unflinching attachment to duty." 
Jacques de la Chaise, to quote Gayarré again:

"was not gifted with superior intellect, but he was a solid square 'block of honesty' who moved solidly onward in the accomplishment of his mission, regardless of persons and consequences. The never ceasing repose of his handsome features was an unmistakable indication of the unruffled serenity of his soul and the dignity of his person; and the measured propriety of his deportment and actions was such that it checked in others the ebullition of passion, forcing discussion to be courteous and anger, itself, to be respectful. With the blandest urbanity but with unswerving firmness, he called every one to account and met serenely the opposition of those whom he goaded into fury by his steadiness of purpose. . . ."*

Bienville was recalled to France to answer the charges which his implacable enemies had for years been bringing against him; and his cousin, Boisbriant, appointed Governor ad interim, on de la Chaise's report, he also was summoned to France. Three members of the Council were dismissed from office; the Attorney-General's resignation was demanded, and his office suppressed for the time being. The disgraced officers were ordered to appear before Perier and de la Chaise, and to stand trial for their official acts. Instructions were also issued to Perier, that he should be the executive and military commander of the colony, but that de la Chaise should have official supervision of its police and executive judicial administration.

It was a gloomy period in the history of Louisiana, and the distress of the colony had reached an acute stage. The supplies sent from France failing, famine began to threaten, and the distress was increased by a hurricane, which caused the most extensive damage; the paper currency had been reduced to such a state

${ }^{*}$ His portrait and that of his wife are possessed by Colonel Hugues de la Vergne. 
of discredit that it ceased to pass; hence a cessation of business. To make the situation worse, the Natchez Indians, goaded by the tyranny of the French officers over them, began murdering and pillaging traveling traders, while they secretly prepared for a general revolt and massacre of all the whites in their land. This was bloodily and successfully accomplished in 1729 .

It would seem, from the following letter, that at the time of the massacre, de la Chaise was making one of his official tours of inspection, accompanied by Governor Perier:

Fort Chartres, April 14th, 1730.*

"The dugout of M. Périer and M. de la Chaise made - leagues to the place in all haste to advise us of the massacre of the French established at Natchez.

"Terrisse de Ternan."

Le Page Dupratz concludes his account of the Natchez massacre with a panegyric on de la Chaise:

"Those orphans and widows who escaped from the Natchez massacre would be extremely ungrateful if they did not all their lives pray for the soul of that good and charitable man."

But not only on the widows and orphans were his heart and mind directed, as the following document, remarkable for its time, shows:

"To the Councillors of the Superior Council of the Province of Louisiana:

"Exposed to a disaster like that which happened at Natchez, where all the inhabitants were inhumanly massacred, obliged to have recourse to all sorts of means to baffle these barbarians, the most pressing need was speedily to advise the distant posts to be on the alert. M. Périer found men of good will who offered to

* Wrong date. The Natchez massacre took place in 1729; de la Chaise died in February, 1730.-Acthor. 
undertake the perilous journey. They were accompanied by a few negroes, chosen from among the boldest, and they were promised freedom if they inviolably kept their word. There are also several other negroes who at the time of the Natchez siege gave proofs of valor and attachment to the French nation, and exposed themselves to peril with intrepidity. Some were even wounded, and as this is a very important affair, and as it is a question of holding the negroes and attaching them, so that we may rely on them on such occasions, the question is to find means the best calculated to attain that end. We believe we cannot reward them otherwise than by granting them freedom. That will give others a great desire to deserve similar favors by material services; and, besides, a company may be formed of free negroes that can be placed in the posts which the commander will judge proper, which company is to be always ready to march on short notice.

"As there were then a great number of negroes at Natchez, I do not exactly know who did best and who will be rewarded; therefore they will be chosen from the reports and testimony of the officers in this war and on the account given by them to M. Périer, who will choose them. We cannot do better than to refer this to him and beg him to demand an account of their good and bad qualities. This considered, may it be your pleasure to grant freedom to the negrocs who went to Illinois, and to whom M. Périer judges it to be proper to give the same. In the report made to him, conditions and clauses prescribed by the 'Black Code' must be adhered to."*

De la Chaise found at Natchez Le Page du Pratz, the historian who had been living among the Indians there for eight years, perfecting the invaluable study of the tribe, their language and their customs, that fill the best pages of his history. This historian, who was also a botanist, made a study of the medicinal plants used by the Natchez, and a collection of three hundred of them, which the enlightened de la Chaise sent to France, with a Memoir on the subject by du Pratz. The plants were confided to the

* From the Louisiana Historical documents. 
Jardin des Plantes, of Paris, where there still exists a record of them.

Before Bienville's departure (1724), and almost the last act under his rule, was the promulgation of the "Code Noir" by the Superior Council. De la Chaise's signature follows that of Bienville on this most important document. In the division of authority between Périer who succeeded Bienville and de la Chaise, as Dart says:

"De la Chaise became apparently the sole law officer of the Crown, at any rate for the time being, and devoted himself earnestly to his judicial duties, settling disputes and simplifying the law. . . . ."

His power to override constitution and customs is illustrated by Gayarré, in the action of the Superior Council on a question of community. To continue the interesting quotation from Dart:

"There had been intermarriages between French emigrants and Indian women, and, upon the death of the husband, it was usual for the wife to return to her people, failing to pay the debts of the decedent and carrying off the property to her tribe, without observing the formalities required by and inherent to the local laws of succession. De la Chaise recommended and the Superior Council decreed that thereafter on the death of a Frenchman married to an Indian woman. the property left by the decedent should be administered by a tutor if there were minor children; if none, by a curator to vacant estates. who should pay annually to the widow one third of the revenue of the estate; which payment should cease in case she returned to dwell with her tribe."

In the records of the Superior Council is preserved an instance of de la Chaise's unswerving directness of purpose in pursuit of justice. He proceeds against Bienville in the one clearly proven instance of injus-

\footnotetext{
* "The Legal Institutions of Louisiana." W. P. Dart, Esq.
} 
tice recorded by history against Bienville, in evicting Pauger, the Royal Engineer, from the land upon which he had settled and which he had improved.

Petitioning as executor for the late M. de Pauger, de la Chaise recalls the land suit between M. de Bienville and M. de Pauger, wherein M. de Pauger was worsted, on the subject of compensation for improvements on the land at issue. The sum of one thousand francs was allowed but it was afterwards claimed by $M$. de Bienville, against the valid rights of Pauger's estate. "Let M. de Bienville be cited in the person of his nephew, M. de Noyan, and the thousand francs be entered to the account of the estate." It is painful to record that the Superior Council sustained Bienville and not his ill-treated antagonist in the decision of the case.

De la Chaise died in 1730, his sudden death giving rise to dark rumors of poison by those who had cause to fear his investigations. He was accompanied to Louisiana by his wife, Marguerite le Cailly, who, according to a popular report, still believed and repeated (although unproven), was related to the family of Jeanne d'Arc.

According to the Census of 1726, de la Chaise, with his wife and two children, occupied a large house on Chartres Street. He left the following children:

Marie Louise, born in Nantes; married in 1729 to Louis Prat, physician and Councillor, of the Superior Council, "a man of regular habits, approved honesty, and a practical Catholic," according to the report of the Clerk of the Council.

Alexandrine, born in Nantes; married to Jean Pradel, Captain of Infantry.

Félicité, born in Nantes; married in 1732 to Louis Dubreuil Villars. 
Marie Marguerite, married to Louis Joseph Bizoton de St. Martin, "officier de Marine."

Jacques, married to Marguerite d'Arensbourg.*

Councillor Prat, acting as guardian of the minor children, petitioned the Superior Council in June, 1730 , for authority to pay them quarterly installments yearly, advanced from their portions of the estate for their support, "as the Council may approve"; Madame Pradel also to receive an allowance up to the date of her marriage.

The estate of de la Chaise showed no accumulation of wealth during his terms of office. The inventory of it is in the archives of the Louisiana Historical Society, but unfortunately is not available for scrutiny. His plantation, situated above the city, facing the river, was not a large one, its working force consisting of only thirty-five slaves. The upper districts of the city were known at one time as de la Chaise, Gayarré mentioning that the de Boré plantation was situated in de la Chaise. One street in New Orleans remains to bear the name.

A few outstanding debts were presented to the Council for payment: One for two hundred and twenty francs due on "wig" supplies; another for thirty francs for making a "fine shirt" for the late M. de la Chaise. And, again, "R. B. Petit, of the S. J., claims two hundred and twenty-eight francs for some wrought iron made by the Society's blacksmith for use on the de la Chaise plantation."

Auguste de la Chaise, the son of Jacques de la Chaise and Marguerite d'Arensbourg, attained a lurid notoriety in his day as a member of the Society of French Jacobins, established in Philadelphia in 1794. The distribution of their inflammatory

* Parish Register of St. Louis Cathedral. 
addresses in New Orleans through secret agents caused great uneasiness and alarm to Carondelet. The alarm was increased by Carondelet's knowledge of the efforts being made by Genet, the French Minister, to raise an expedition against Louisiana, with the aid of the discontented people of Kentucky and Tennessee. De la Chaise was sent to Kentucky by Genet to recruit forces, and he was counted upon to lead the invaders down the Ohio and Mississippi.

Gayarré writes that of all the agents employed by Genet, de la Chaise was the one most feared by Carondelet, on account of his rash intrepidity, his indefatigable activity, and his exquisite address; and because, being a native of Louisiana, and belonging to one of its most powerful families, he exercised considerable influence in the city. ${ }^{*}$

But, as we know, the firm interference of Washington checked the intrigue of Genet, and the revolutionary plan aborted. In his disappointment, de la Chaise abandoned his hopes of wresting Louisiana from the power of Spain. He retired from Kentucky and took service in the French Army, leaving behind him this document as his last political testament and will:

Address of de la Chaise, laid before the Democratic Society of Lexington:

"Citizens:

"Unforseen events, the effects of causes which it is unnecessary to develop here, have stopped the march of two thousand brave Fientuckians, who, strong in their courage, in the justness of their rights, in the purity of their cause, and in the general assent of their fellow-citizens, and convinced of the brotherly dispositions of the Louisianians, waited only for their orders to go and take away, by

* "Spanish Domination." Gayarré. 
the irresistable power of their arms, from those despotic usurpers, the Spaniards, the possession of the Mississippi, secure for their country the navigation of it, break the chains of the Americans and of their French brethren in the province of Louisiana, hoist up the flag of liberty in the name of the French Republic, and lay the foundations of the prosperity and happiness of two nations destined by nature to be but one and so situated as to be the most happy in the universe.

"Citizens, the greater the attempts you have made towards the success of that expedition, the more sensible you must be of the impediments which delay its execution, and the more energetic should your efforts be towards procuring new means of success. There is one from which I expect the greatest advantages, and which may be decisive-that is an address to the national convention, or to the Executive Council of France. In the name of my countrymen, of Louisiana, in the name of your own interest, $I$ dare once more ask you this new proof of patriotism.

"Being deprived of my dearest hopes, and of the pleasure, after an absence of fourteen years and a proscription of three, of returning to the bosom of my family, my friends, and my countrymen, I have only one course to follow-that of going to France and expressing to the representatives of the French people the cry, the general wish of the Louisianians to become part of the French Republicinforming them at the same time, of the most ardent desire which the Kentuckians have had, and will continue to have forever, to take the most active part in any undertaking tending to open to them the free navigation of the Mississippi. The French Republicans, in their sublime constitutional act, have proffered their protection to all those nations who may have the courage to shake off the yoke of tyranny. The Louisianians have the most sacred right to it. They are French but they have been sacrificed to despotisin by arbitrary power. The honor, the glory, the duty of the National Convention is to grant them their powerful support.

"Every petition or plan relative to that important object would meet with the highest consideration. An address from the Democratic Society of Lexington would give it greater weight.

"Accept citizens the farewell, not the last, of a brother who is determined to sacrifice everything in his power for the liberty of his country, and the prosperity of the generous inhabitants of Kentucky. Salut en la patrie.

"Auguste la Chaise." 
De Pontalba, in a letter to his wife, October 13th, 1794 , speaking of the general uneasiness in the city over its impending Jacobin uprising, adds:

"Madame Marre has just eome from Charlestown; she has been to the Government (house) and repeated that la Chaise told her in New England, where he is, that it was he who fomented the troubles which we had had in Point Coupée, adding that he had not succeeded that time, but that he would do better next time; he told her he was only waiting for his dispatches as Consul of France, to eome here by way of Kentucky, and that he would show there instruetions that would make the negroes know what their rights were.

"Madame Marre protested that Louisiana was his country, that his parents were there and his friends, and that this should deter him from bringing trouble there, with horror, ruin, and assassination; he replied that humanity eame before such titles, and that the negro men were his compatriots as well as the white men. Madame Marre gave the names of persons who heard this eonversation; they are all here and their declarations will be taken, a summary made, and afterwards, orders will be given to high and low, that he must not be allowed to enter the colony if he seeks to. He has done everything that he could to excite the negress of Madame Marre; telling her she was free, that slavery was horrible, that no one had the right to hold her in it-either her or any of those held so in Louisiana. Such a subject is a great eurse to this provinee."

Auguste de la Chaise married the daughter of Pierre Foucher, the granddaughter of de Boré. There is no further record in Louisiana of the name. $\mathrm{He}$ perished in an ambuscade in St. Domingo in 1803 , shortly after his elevation to the grade of General. Gayarré concludes his account of him with the not very enthusiastic praise:

"Had not death stopped him in his eareer, when he was still in the meridian of life, it is to be presumed, from what he had already accomplished, he would have risen to higher honors; and might have left behind him a memory of which his native country, Louisiana, would have been proud." 


\section{CHAPTER X \\ LAFRÉNIÈRE}

NICOLAS DE LAFRÉNIÈRE stands in the his1 tory of Louisiana and in the annals of New Orleans upon a pedestal that raises his heroic gfiure even above that of Bienville, whose long devoted life of hard service missed the consecration of a glorious death.

Lafréniere, like Bienville, belonged to a family that seemed sent by history into the new country on a mission.

Like the Lemoynes, the Chauvins came from France to the new world to seek their fortune in the strenuous pioneer days of Canada. Pierre Chauvin, a native of Anjou, the first of the name, son of Réné and Catherine Avard de Solesne, lived in Montreal in 1658, receiving his grant of land in 1654 .

He married Marthe Autreuil, daughter of Réné and Françoise Lachaunerlin. Four of their seven sons followed Bienville to Louisiana. Like the Lemoynes, they affixed to their family names titular designations: De Léry, Beaulieu, de Lafrénière, Boisclair, and the like.

As Ulloa, in his report upon the insurrection in Louisiana, succinctly states:

"Of the common people Bienville brought over with him were four brothers who afterwards assumed different surnames in Louisiana, one causing himself to be called Lafrénière; the other Léry; the third, Beaulieu; the fourth, Chauvin. These four Canadians 
were so low in extraction and had so little education, that they could not write and had come with an axe on their shoulders to live by their manual labor. The sons of these men are now the chiefs of the rebellion."

The four brothers were:

Jacques (married to Jeanne Dauville);

Joseph de Léry (married to Hypolite Mercier);

Nicolas Lafrénière* (married to Marguerite Le Sueur);

Louis Chauvin de Beaulieu (married to Charlotte Dural).

There were two daughters, Barbe Thérèse (married to Ignace Hubert de Bellair) and Michelle Chauvin (married to Jacques Nepveu).

During the hard epoch of the settlement of the colony, when Bienville had to maintain himself against Spaniards, English and Indians as well as against domestic foes, and fight no less strenuously against starvation when the colony was forgotten or neglected by the mother country, he found in the men with the axe on their shoulders, the illiterate, hardy Canadian "coureurs de bois," his most effective fighters against overwhelming odds. Indefatigable in daring enterprise, courageous beyond all tests, indomitably loyal, unconquerable by famine, they, and not the feeble military garrison provided by the Royal Government, held the province for France, and kept the fleur-de-lis flying over the fort at Mobile.

The Chauvins are met in historical chronicles during this period whenever and wherever need was

* A recently discovered document in the Louisiana Historical Society collection states that Lafrénière, after his arrival in the colony, learned to read and write in four months. 
found for their services, if not in the lists of military promotions or awards of honors.

In 1716, when Louisiana was under the régime of the Crozat Charter, St. Denis, it may be recalled, was sent from Mobile to Mexico in an attempt to create an opening for French trade with the Spanish provinces. After many adventures, military and amorous, St. Denis returned to Mobile to report the utter failure of his commercial effort, but the complete success of his love affair with the daughter of the Spanish Viceroy, whom he married and left at the Presidio del Norte to await his return.

The three Chauvin brothers, De Léry, Lafrénière and Beaulieu, were then dispatched with merchandise from Mobile to engage in trade with Mexico. They acquitted themselves less romantically, but, balked by Spanish vigilance, they met with no better commercial success than St. Denis.

The Chauvins followed Bienville from Mobile to Biloxi, and to the proposed site of the city of New Orleans, there selecting for themselves choice concessions in the Tchoupitoulas district, where they established plantations. Working in their bold, energetic, enterprising way, they soon became known as money-makers. On a census taken at the time, de le Roy (Déléry) and Bellair are mentioned as settled on the immense concession that Bienville himself had obtained, extending from New Orleans to the Tchoupitoulas, and upon this settlement lived Chauvin Deléry with three children, and Chauvin de Lafrénière, who also had a wife and three children.

There is record before the Superior Council, in 1724, of a sharp legal dispute between the Chauvins and the owner of the neighboring plantation, $M$. 
Céard, over the digging of a ditch and the raising of a levee which caused an overflow on the Céard lands. In spite of Lafrénière's spirited defense, the Council decided against him, ordering him to build a coffer dike for the protection of Céard's lands under the supervision of Broutin, the Royal Engineer-the costs of the court to be paid by the Chauvin brothers.

Nicolas Chauvin de Lafrénière, the third brother, had married Marguerite Le Sueur. Their son became Louisiana's famous man. Marguerite Le Sueur was presumably (but only presumably) the daughter of the celebrated explorer of the Upper Mississippi; and the ardent adventurer in search of copper mines. He was a Canadian and had followed Iberville to Louisiana, where he died, leaving his wife and family in Mobile.

There exists, unfortunately, no data concerning the early days of Lafrénière's childhood. Even the date of his birth is uncertain and can only be guessed at approximately as 1720 . He was, doubtless, one of the three children that were taken to the plantation on the Tchoupitoulas Road and he must have received the elements of his education from some primary instructor such as generally at that time kept a small school for the children of planters in the neighborhood of rich plantations.

We come into the light of historic certainty with the authoritative statement of Gayarré that Lafrénière was sent to France for his education and there, during his long sojourn, studied civil law. He married Marguerite Hubert de Belair, a cousin, daughter of Ignace Hubert and Barbe Thérese Chauvin, half sister of Joseph Roy Villeré.

The register of the Cathedral contains the record 
of the baptism of two daughters: Catherine Chauvin de Lafrénière, born in 1750; and Marguerite Catherine de Lafrénière, born in 1753. The latter married in 1767 Jean Baptiste August de Noyan, captain of cavalry, son of Augustin Payen de Noyan, Chevalier of St. Louis, a Lieutenant of the King, and nephew of Bienville.

In 1740, Lafrénière's name, as Counsellor of the Superior Council, figures among witnesses of the marriage contract of his cousin, Déléry des Islet, Charlotte Faucon du Manoir. Gayarré mentions, without explanation, that he returned to Louisiana in 1763 on the same ship with d'Abbadie, the Governor newly appointed to succeed Kerlerec, carrying in his pocket his appointment as Attorney-General and the decree of expulsion to be executed against the Jesuits.

They landed in New Orleans in June, 1763. The decree against the Jesuits was published at once. It restated merely the decree that was being executed in Europe against the order; that as the institution of the Jesuits was hostile to the Royal authority, public peace and safety, their vows were proclaimed nul; they were prohibited to call themselves thereafter by the name of Jesuits and to wear the garb. All their property, except some books and wearing apparel, were to be seized and sold at public auction; their sacred vessels were to be delivered to the Capuchin Fathers; their chapels were to be demolished, their cemeteries destroyed and their priests ordered to return to France by the first ship ready to depart.

According to the Relations of the Jesuits, and the authorities of the time, the execution of the decree by the young, newly appointed Attorney General 
lacked nothing in stern vigor, although he was implored to moderate his zeal. And notwithstanding that he honored the Fathers with a personal visit, and assured them of the pain he felt in discharging his disagreeable duty, he nevertheless discharged it in such a way as to incur the hot resentment of the inhabitants, who have not failed to placard his memory with despicable accusations that remain to this day. Among them, it is not surprising to find him called an atheist, as a result of association with the brilliant freethinkers of Paris, and from other associations he was said to have formed a taste for society of gay morality.

But Gayarré and other historians paint a different picture of him:

"Large, well-formed, with noble appearance, impressive, brave, with eyes lightened as if by fire; in short, so remarkable a person that people not knowing with whom to compare him, called him Louis XIV! . . . Good beyond all tests, loving his fellow citizens like brothers, possessed of all the qualities that make a loved husband, father, friend. Charming and agreeable in his speech, with all the grace and charm of manner acquired in the most polished society of Europe. . . .

"Sweet tempered and moderate in all ordinary situations of life, he was as if electrified with passion on serious occasions, and none could resist the torrent of his eloquence."

As a matter of course, therefore, he was the object of the most flattering popular attentions of New Orleans, and the wonder and admiration of public assemblies.

The result of the decree against the Jesuits, the confiscation of their property, including the fine plantations above the city upon which they were making the experiment of planting sugar cane, the closing of their chapels and the abrupt termination 
of their religious and educational benefactions to the community, the parting with beloved pastors and friends, threw New Orleans into acute distress of mind and heart, from which it had not recovered when the Treaty of Paris, signed in 1763, was made public in 1764 .

The Louisianians had followed with the shrewd eyes of Indian fighters the progress of the war in Northern America between the English and French. That France as a consequence of defeat should be forced to give up her American possessions to her victorious rival had been foreseen, with the cool stoicism of good fighters; and the humiliating sight of the English boats sailing up and down the Mississippi River carrying provisions and men to the newly acquired English possessions was one their eyes were growing accustomed to.

The city, with its territory, the Island of Orleans, as it was called, alone remained to France and, as it may be imagined, never had the fleur-de-lis flown more proudly and bravely after its humiliating withdrawal from Canada than it did over the small sovereignty remaining to it in Louisiana; and never was sovereignty more loyally and devotedly acknowledged by the city of New Orleans than in the hour of French defeat. The city contained only 3,190 inhabitants, but the population of New Orleans has never, in political crises, been reckoned by mere numerical physical statistics. At this time it was less to be so reckoned than ever. The city seemed at last on the point of fulfilling the arrogant hopes of its future that had been sown in the time of Bienville, and the colony, after bravely struggling for half a century, had at last made a sure foothold in 
the soil. Rewards for past suffering were flowing in. Commerce was beginning to prosper, and agriculture to be profitable. The conditions of life were being softened into luxury by wealth. Population was increasing. The Indians were flocking everywhere to the French settlements; the English, busy taking possession of their new acquisitions, were friendly and content.

The political horizon, viewed from the city, was never freer and clearer than when the greatest cloud of its history burst over it, in the publication of an official letter from the King to M. d'Abbadie. It stated that, by private act passed at Fontainebleau, on November 3d, 1762, he had by his own free will ceded to his very dear and beloved cousin, the King of Spain, and to his successors and heirs in full property, completely and without reserve or restriction, all the country known under the name of Louisiana, as well as New Orleans; and that by another act, signed by the IKing of Spain on the thirteenth of November of the same year, His Catholic Majesty had accepted the cession!

Historians, in default of more appropriate expression, merely write that the colony was plunged into the deepest consternation. Gayarré being in touch, as he was, with the sentiments of his grandfather, describes the heartfelt bitterness, the talk and the feelings which spread through the streets, and which the streets of New Orleans were too small, in truth, to contain:

"As Frenchmen, they felt that a deep wound had been inflicted on their pride by the severing in twain of Louisiana, and the distribution of its mutilated parts between England and Spain. As men, they felt the degradation of being bartered away as marketable 
objects; they felt the loss of their national character and rights, and the humiliation of their sudden transformation into Spaniards or Englishmen, without their consent. As colonists, as property owners, as members of a civilized society, they were agitated by all the apprehensions consequent upon a change of laws, manners, customs, habits and government."

There ensued a moment of panic with loss of nerve. Lafrèniere, the popular favorite, was the first to recover his presence of mind and logically, in his case, flew to legal measures of defense. By a political innovation, daring at that time, he appealed to the people, calling a public mass meeting of representatives from every parish in the province to consider the question of the cession. The response was enthusiastic. A vast number crowded to the meeting. Among them were Villeré; the Chevalier d'Arensbourg; Maxent; de la Chaise; Marquis, the commander of the Swiss troops; Doucet, a distinguished lawyer recently arrived from France; St. Lette, Pin; Jean Milhet, the richest merchant of the city; Joseph, his brother; de Boisblanc; de Grandmaison; de Lalande; Le Sassier; Kernion-all prominent names of the best and strongest men in the city and country.

Lafrénière called the meeting to order, made an eloquent speech explaining the situation, and submitted a prepared resolution of protest-a sincere document, written in simple language, expressing passionate devotion to the mother country and to the King, ending with a heart-rending plea not to be divorced from France, not to be made to change the name of Frenchmen for that of Spaniards. The resolution was enthusiastically adopted, and Jean Milhet was deputed to carry it to France and lay it 
at the foot of the throne. A year elapsed before Milhet returned, but no Spaniard had presented himself to take possession. On strength of the socalled truism that "no news is good news," the passions of the excited population began to calm down and, "like little wanton boys," they swam on bladders, until Milhet did return to report that he had not even been able to gain access to the King or to deliver the protest; and almost at the same time in June came the announcement that Don Antonio de Ulloa had been sent to take possession of the province!

August, September, October, November, December passed away. Governor d'Abbadie died and was succeeded by Aubry, the military commander, a Frenchman and only a Frenchman - with no thought save for his military duties. The year 1766 opened, and still no Spaniard appeared.

"Many of the colonists," says Gayarré, "now adopted the conviction that the Treaty of Cession was but a sham instrument, concealing some diplomatic manœuvring."*

But on the fifth of March the unexpected, the impossible, happened. Ulloa arrived, accompanied by two companies of infantry, and the Spanish officials of the government to be set up: a Commissary of War, Loyola; an Intendant, Gayarré; a Treasurer, Navarro. Aubry, the Governor, received them according to the ceremonious military etiquette of the day, while the concourse of citizens looked on in sullen discontent. He had previously convened all the French officers and laid before them the instructions he had received from his government

* "French Domination." Gayarré. 
to put the military forces at the disposal of the Spanish Governor; and he consulted them on the practicability of coercing the troops inio the service of Spain. The officers refused unanimously to go into the service of Spain, and warned him that the attempt to coerce the French soldiers would be exceedingly dangerous.

The next step in the transaction should have been for Ulloa to exhibit his powers to the highest court authority in the province, the Superior Council, who alone could deliver the province to him. He refused to do this on the ground that he intended to postpone taking possession of the country until the arrival of all the Spanish forces that he expected, adding that he had nothing to do with the Superior Council, which was only a civil tribunal by which he could not possibly be called to account. With regard to the delivery of the province into his hands, he declared that he had to deal only with Governor Aubry, whom he recognized as the sole competent authority on that matter.

Autocratic insolence could go no further. The issue was made clearly now, not between the inhabitants and Spain, but between the civil and military authorities. Unquestionably, if Ulloa had proceeded to the Council, then in session, and had followed the proper formalities, as requested, he could have been put in possession of the province peaceably and legally.

Ulloa's military weakness and his insolent arrogance fanned the sparks of hatred existing already against him and his government. New Orleans was soon seething with revolutionary talk, the fury of which he kept at a white heat by his subsequent 
conduct. While refusing to take formal possession of the colony, he proceeded to exercise all functions of the Governor of it. He visited various posts, remaining some time in Nachitoches the sensitive spot on the border between Spanish and French possessions, and in each place, with the tacit consent of the subservient Aubry, raised the Spanish flag and lowered the French. He ordered a census of the colony. The commercial restrictions he imposed were all for the benefit of Spanish trade and ruinous to the interests of New Orleans.

In September, a file of soldiers with fixed bayonets, heralded by the loud beating of a drum, proclaimed, by order of Aubry, an ordinance dictated by Ulloa, according to instructions received from Spain. As Aubry wrote to his government:

"I command for the King of France, and at the same time I govern the colony as if it belonged to Spain!"

The Superior Council was composed of no insignificant men, as their names and titles show: Foucault, the Commissary-General of France; Lafrénière, the Attorney-General; de la Chaise; Le Sassier; Laplace. They were not the men to be flouted with impunity, or to look on supinely while a foreign usurper, as they considered Ulloa, exercised their functions and ruined their country. They met in secret caucus, as it would be called to-day, and discussed what could be done, not to hold the province to France, but to drive the Spaniards away.

Lafrénière was, as usual, the leader; Foucault, the King's Intendant, was his right hand; their followers were: Masan, a retired Captain of Infantry who had served under Bienville-a middle-aged 
man who had become a wealthy planter and Chevalier of St. Louis; Marquis, Captain of the Swiss soldiers; the two nephews of Bienville-the one called Bienville, a Captain of Cavalry; and Noyan, a Lieutenant in the Navy; Doucet, a lawyer, just arrived from France; the Milhets; Caresse; Poupart; Hardy de Boisblanc; and Villeré, brother-in-law of Lafrénière, and Commander of the German Coast. The band of patriots met secretly, either at Masan's house or at Madame Pradel's (a friend of Foucault's), on the outskirts of the city, a villa which was surrounded by a large garden, shaded by magnificent magnolias.

The conspirators would drop in one by one, and, when their number was complete, would unfold and discuss their plans; after which they would saunter in the perfumed alleys of roses, myrtles and magnolias and end the evening with a luxurious banquet. The secret of their meetings was so well kept that Aubry and Ulloa learned of it only late in October, when all the plans were matured and when the programme of proceedings was decided upon.

On the twenty-seventh, Foucault called a meeting of the Superior Council for the next day. The day before this sitting of the Council, a public meeting was held; it was addressed by Lafrénière in a fiery speech, of which Gayarré publishes a fragment:

"Sirs, we are arrived at a moment of crisis, when we must face with vigor. In desperate cases we must have recourse to desperate measures. What greater misfortune could we suffer than that to being no longer Frenchmen. What shame to be sold as slaves to a foreign nation whose language we do not know! Our possessions they are naught: our life, our honor will be put under laws that we know nothing of. Let us follow the noble example of the people of Burgundy, when Francis the first, abandoned by fortune on the 
plains of Pavia, consented to buy his liberty at the price oi one of the most beautiful provinces of France. The nobility of Burgundy replied with unanimous voice to Launoy, who came to take possession in the name of the King of Spain: 'The French soil is unalienable, therefore the King of France cannot transfer it to a foreign power! French by birth and by our hearts, we will know how to live and die as Frenchmen! If the King of France persists in abandoning use, come and take us!"*

The Superior Council met as convened by Foucault. Only five members were present, the rest excusing themselves on the plea of sickness. Caresse, being introduced, presented a petition signed by six hundred planters, merchants and other citizens, demanding the restoration of their rights and liberties as Frenchmen, and demanding the expulsion of Ulloa. The petition was said to have been written by Lafrénière and Doucet.

It was not read at the Council, but was referred to two members, Huchet de Kernion and de Launay, with instructions to present it next day.

In order to restore the Council to its full strength, Lafrénière moved to replace the absent members by appointment, and six were chosen on his and Foucault's recommendation. During the night of the 27th the guns at the Tchoupitoulas Gate were spiked; the next morning Villeré, at the head of the German settlers, all armed, entered the city. The Acadians, $\dagger$ also armed, under Noyan, followed the Germans. The planters along the coast joined their confederates.

* "Essaie Historique sur la Louisiane, 1830." This fragment, Gayarré says, was found in an old manuscript, but the manuscript has been lost.

$\dagger$ In 1765, about six hundred and fifty Acadians had arrived in New Orleans and had been sent to settlements in the Attakapas and Opelousas districts, where their descendants still live and thrive. 
Marquis took command of the insurgents. Alarm and confusion spread through the town. The Spanish frigate withdrew to the other side of the river. Aubry distributed cartridges to his small band of one hundred and ten French soldiers, after sending for Lafrénière and Foucault and in vain imploring them to desist. Ulloa and his household prudently retreated to the Spanish frigate; Gayarré, Loyola and Navarro barricaded themselves in the Government House. On the 29th, the next step was taken: the Superior Council met to take the petition of Caresse into consideration, but before deliberating inquired of Aubry whether. Ulloa had exhibited to him his powers to take possession of the colony in the name of the King of Spain? Aubry answered that nothing decisive on the subject had ever been shown.

Then the Attorney-General arose with the question: "Is yours a competent tribunal? Are these complaints in the petition just?" anc' proceeded to open an elaborate, thorough and convincing argument; a scholarly exposition of the legal position of the Superior Council and the illegal assumption of authority on the part of Ulloa. After listening to it, and to the report of the committee, the decree against the government of Ulloa was granted, and Ulloa was enjoined to leave the colony in three days.

Gayarré mentions with pride a passage in Lafrénière's address before the Council:*

"Without liberty there are but few virtues. Despotism breeds

* This able document is printed in full in the appendix of Gayarre's "French Domination." 
pusillanimity, and deepens the abyss of vice. Man is considered as sinning before God only because he retains his free will."

As Gayarré comments, to appreciate this bold language it must be remembered that it was officially uttered by the Attorney-General of an absolute monarch and that it was intended to reach the ears of the despotic government of France.

Each one of the thirteen members of the Council gave his opinion separately and in writing, that of Hardy de Boisblanc being distinguished by its violence against Ulloa. The decree prayed for was granted-the Council framing it in almost the exact words of Lafrénière. It was also resolved that collated copies be sent to the Duc de Choiseul.

In the meantime the excited populace, gathered in the Place d'Armes, were giving vent to the wildest clamor against Spain and for France. When the decree issued by the Superior Council was communicated to them, the most intense enthusiasm thrilled them; women and children rushed to the flagstaff that bore the banner of France, and embraced it frantically.

Two days later Aubry sent to one of the Ministers of France a detailed account of all that had taken place. He writes, exonerating himself from any responsibility in an action that he says, plaintively, he considers one of the greatest outrages that could be committed:

"I protest against their decree which orders the expulsion within three days of him whom His Catholic Majesty had sent to take possession of the colony."

This despatch was entrusted to a Knight of St. Louis who was instructed to give all further information needed about the revolution. 
The Superior Council lost no time in sending also their account of what had taken place. Their messengers were Le Sassier, one of their members, and Bienville, of the Navy, with Milhet to represent the merchants. Bienville was debarred from serving by his military duties and St. Lette was named in his place.

In the evening of the same day, October 31st, Ulloa embarked with his family and attendants on a French vessel that he chartered, alleging that the Spanish frigate needed repairs.

The following morning, November 1st, a band of merrymakers from a wedding feast, who had passed the night frolicking, could not restrain themselves at the sight of the French vessel moored at the bank. With shouts of exultation they saw Petit, one of their number, cut the ropes that made the ship fast to the shore; and as it slowly moved away on the current of the river they flung their cries of derision until it passed out of sight.

The coup d'état had been accomplished. The colony had repulsed both the French and Spanish effort against its liberty and had shown what was the quality of its manhood. The planters and merchants put forth as their final justification a Memorial repeating the arguments contained in the address of Lafrénière before the Council, reinforced by their proven allegations. This Memorial, as it is called, was printed by Braud the Royal Printer, on the order of Foucault. The Memorial was evidently written by Lafrénière.

"What harm have we done" it asks, "in shaking off a foreign yoke? What offense have we committed in claiming back our laws, our country, our sovereign? Are such laudable attempts without 
an example in our history? Has not more than one city in France, such as Cahors and Mautauban, and even whole provinces, such as the Guerci, the Rouerque and Gascony, repeatedly broken with patriotic courage the English yoke, or refused to be fettered by foreign chains? Noble resistance to the decrees of our natural born sovereigns, far from kindling their wrath, stirred up the fountains of their attachment and forced them into helping their loving subjects and thus wrought out their deliverance!"

The Superior Council also addressed to the Prime Minister a communication forwarding its decree to be laid at the foot of the throne. With this document went a letter from Foucault justifying what had taken place, and Aubry added another letter in which he had the courage to say:

"I foresaw the unfortunate event which has occurred. . . . M. de Ulloa was not the proper person to govern this colony, notwithstanding his vast interest . . . and although he is full of honour and probity, and zeal for his sovereign, he does not possess the necessary qualifications to command Frenchmen. . . . He has done all that he could to alienate them. He seemed to despise the first men of the colony and particularly the members of the Superior Council. . . . He has alarmed everybody . . . and contributed not a little to draw down upon himself and his realm the storm that has swept him away."

All fruitless . . . France, destined a score of years later to be the torchbearer of liberty to all the world, was still a slave in chains; and the patriots of Louisiana, worthy to stand in the ranks of the great liberators of people, were coldly condemned by a mere turning down of thumbs!

Ulloa arrived safely in Havana, whence he at once sent his report of his expulsion from Louisiana to his government, making as good an argument for himself as his antagonists had made against him. He showed in it that he was fully aware of the state of feeling of 
the colonists at the time of his arrival, and thoroughly cognizant of the efforts they were making to frustrate the cession. His report, indeed, is so well furnished with information, that historians have supplied themselves from it.

Ulloa states that when the revolt was only in contemplation, de Bienville, the brother of Noyan, and Masan, son of the "Conspirator," went secretly to Pensacola to solicit assistance of troops from the English Governor-General to support the insurrection; upon his refusal to do this, the proposal was made to transform the colony into a republic under the protection of England. This being discouraged, they then boldly determined to rise in their own strength and trample under foot the orders of their Sovereign. Lafrénière he names as the one single man who put the colony in a state of insurrection, and that it is not the first time that his "seditious maxims" had caused trouble.

In the report of Ulloa above quoted, he states that Kerlerec had, in a letter, mentioned Lafrénière to him as one of the turbulent spirits whose intrigues and practices had agitated the colony during his administration; and that M. d'Abbadie, who had succeeded Kerlerec, had made the same complaint.

The news of the revolution in Louisiana reaching Spain in forty days, a Cabinet Council was held to determine whether the colony should be retained or returned to France. On account of its extreme importance geographically, it was resolved to retain it; and to use force to reduce the colonists to submission, the necessary measures to be taken without delay. Don. Alexander O'Reilly, Lieutenant-Gen- 
eral of the Royal Armies, was given powers to effect this.

While the fate of Louisiana was thus settled in Spain the colony had resumed a certain degree of apparent tranquility.

Says Gayarre: "The excitement of action having given way to calm consideration, what would France do? what Spain? became the anxious questions of the hour. The crowd which had filled the Place d'Armes with its clamor began to shrink. The leaders alone maintained their proud attitude, under the lowering cloud, with unfaltering courage."

The Spanish frigate, still anchored in the river, was at last forced to relieve the city of its menacing presence. But the three Spanish dignitaries, Loyola, Gayarré, and Navarro, remained to make friends for themselves, if not for their government. It was in this interim of somber disquietude that the proposition was made to expel Aubry and his few French troops; to proclaim New Orleans a free port; to form a republic where the oppressed and needy among all the nations of the earth would find a refuge and a home. The chief of the republic was to be styled a Protector. A bank, on the plan of that of Amsterdam or Venice, was to be created to furnish the financial support of the commonwealth.

The Swiss captain, Masan, originated this scheme of a republic, violently and openly recommending its adoption, and it became a subject of public discussion and was circulated in the colony through manuscript and printed documents.

"There is no doubt," says Gayarre, speaking with his usual authority, that the colonists would have eagerly adopted this form of government, for they had always been republicans in spirit." 
But although the idea was abandoned as Quixotic, it nevertheless bequeathed to Louisiana the right of claiming to be the first European colony in America that formed the design of proclaiming her independence.

In the meantime, rumor spread that Spain was making formidable preparations against Louisiana and the leaders of the revolution were urged to seek safety in flight to the English possessions. This they scornfully refused to do, determined to remain in Louisiana with their fellow citizens.

It was on the morning of July 24th, 1769 , when, as we can imagine, the inhabitants of New Orleans had awakened to their work or their pleasure and were intent only on them, that the city was shaken, as if by an earthquake, by the news that a formidable Spanish fleet had made its appearance at the Balisein command of General O'Reilly. The judgment day had come!

Latent uneasiness of conscience burst at once into violent fear. Any attempt at further resistance was as much out of the question as further attempt at sinning on the last day. Nevertheless, the spirited Marquis stuck a white cockade in his hat and made an appeal to the people to oppose the landing of the Spanish. Petit, with a pistol in each hand, spoke with passionate violence against the Spanish, and was ready, he declared, to blow out the brains of any coward who would not coöperate against them!

In vain! The conviction of the hopelessness of their condition made the populace apathetic to all else. There was no longer any spirit of resistance in them! The leaders of the revolution themselves became alarmed over the desperate outlook. The 
magnitude of the armament against the colony threw them into dismay. They presented themselves before the despised Aubry, as before the possessor of the confidence of the Spaniards. He, with a hypocritical show of real sympathy, cheered them with his belief that, as no blood had been spilt, none would be demanded in expiation; and that the great force of General O'Reilly could not possibly be meant to carry terror and desolation through the land, but merely to insure possession of it. $\mathrm{He}$ advised prompt submission, offering to act in their favor with O'Reilly.

In the evening, Don Francisco Bouligny, a Spanish officer, made his appearance in the city, bearing dispatches to Aubry from O'Reilly, who requested him to take all measures necessary to facilitate the transfer of Louisiana to Spain. Bouligny, with Gayarré, Navarro and Loyola, dined the next day with Aubry, who with emphasis assured them of the return of the people to sentiments of prudence and submission; and on the next morning Aubry, assembling the people in the Place d'Armes, counseled them to make a prompt and entire submission, as the only means to prevent their ruin and that of the colony.

Lafrénière, and it was his most heroic moment, then went to Aubry and informed him that he was resolved to trust to the generosity and magnanimity of O'Reilly. With Marquis and Milhet, he offered to present himself to the Spaniard with the proffer of an assurance of the complete submission of the people to the Spanish Government.

Aubry eagerly accepted the proposition and, with the Spanish officers, the Louisiana gentlemen departed at once for the Balise. Don Francisco Bou- 
ligny presented them to O'Reilly, who received them in state on the deck of his flagship. Lafrénière was the spokesman:

"Excellency, M. Marquis, an ex-captain of a Swiss company; M. Milhet, a lieutenant of militia and a merchant; and I, Lafrénière, a planter and the King's Attorney-General, delegates of the people of Louisiana, come to assure you of their submission to the orders of their Most Catholic and Christian Majesties. . . . The harshness of M. Ulloa's temper and the subversion of the privileges guaranteed by the Act of Cession were the only causes of the revolution which took place in the colony. We beg your Excellency not to consider Louisiana as a conquered country. The orders of which you are the bearer are sufficient to put you in possession of this province. The French are docile and accustomed to a mild government. The colony claims from your benevolence the grant of privileges and from your equity the allowance of sufficient delay for those who choose to emigrate. . . ."

O'Reilly listened with grave dignity and made the answer hoped for. In the course of it, the words "seditious people" escaped his lips. Marquis, interrupting him, objected to the word "seditious" and explained the conduct of the colonists. O'Reilly listened with gentle condescension, detained the gentlemen to dine with him with the most delicate politeness, and sent them back completely reassured.

On the morning of the 17th the Spanish fleet, twenty-four ships in full rigging, colors flying, appeared in front of the city. O'Reilly landed and went to the house prepared for him. During the afternoon the Spanish troops were landed and were received by Aubry at the head of his French soldiers and the Militia. The Spanish troops, numbering two thousand six hundred men, were, it is said, among the choicest of Spain, and had been selected by O'Reilly himself. As they marched from the 
ships with their artillery of one hundred and fifty guns, and battalion after battalion of infantry with colors flying, perfect in discipline and in brilliant equipment, they excited the awe and admiration of the New Orleans people.

All the bells rang merrily and a salute was fired from the guns of the twenty-four vessels. O'Reilly, splendidly accoutered, preceded by guards with silver maces, followed by his staff, advanced toward Aubry, who was standing with the men of the Superior Council, and presented them his credentials, which were read aloud. Aubry released the Louisianians from their allegiance to France. The keys of the city were handed to the Spanish Governor; the banner of France was hauled down. Then all the dignitaries proceeded to the Cathedral, where they were received by the clergy. A Te Deum was sung, and with a pompous parade through the awed streets, the cession was completed in the eyes of the humiliated patriots, but not in those of O'Reilly.

On the day following the stately ceremony, he gave a great dinner to the French and Spanish officials and citizens of distinction; but this, as Gayarre remarks, did not interfere with.the business which he had on hand. He had secretly been gathering documents and papers and depositions of witnesses and, on the very day of his banquet, had summoned Aubry to furnish him, as soon as possible, with the names of the persons who had roused the people to enforce the expulsion of Ulloa-in other words, the chiefs and agents of the conspiracy, as he styled it, demanding in particular the decree of the Council and Memorial of the inhabitants. 
The pusillanimous Aubry responded fully and promptly.

"No Attorney-General," to quote Gayarré again, "could have drawn a more precise and more fatal indictment, concluding with a humble and servile apology of his own conduct."

Aubry's document fixed O'Reilly's determination, and he proceeded through his crafty programme. Without loss of time, while Aubry was with him, he drew to his house under different pretexts nine of the Louisiana patriots. Lafrénière was, of course, among the first.

When they were all in his presence, and Aubry standing by, he tersely addressed them:

"Gentlemen, the Spanish nation is respected and venerated all over the globe. Louisiana seems to be the only country which is not aware of it, and which is deficient in the respect due to that nation. His Catholic Majesty is much displeased at the violence lately exercised in this province, and at the offense committed against his governor, his officers and his troops. He orders me to have arrested and tried according to the laws of the Kingdom the authors of these excesses and of all deeds of violence."

After reading the orders he added: "Gentlemen, I regret to say you are accused of being the authors of the late insurrection. I therefore arrest you in the King's name! Here are your judges." (Pointing to some officers in the room.) "They are as equitable as they are learned, and they will listen to your defense. . . . In the meantime, all your property according to the customs of Spain shall be sequestered. . . . As to your wives and children. . . . I shall grant to them all the assistance of which they may stand in need. A faithful inventory shall be made of your estates and effects, and I invite each one of you now to appoint whom he pleases to be present at that inventory, who shall also countersign it."

The astounded prisoners gave the names of those who were to represent them. "Now, gentlemen," concluded O'Reilly, "please deliver up your 
swords." The house during this scene had been surrounded by troops and the room filled with grenadiers. One of the Spanish officers received the swords and, with an officer holding each arm, the Louisianians were conducted from the room to their places of confinement where they were all separated and not permitted to communicate with one another.* Some were put in O'Reilly's Spanish frigate, some in other vessels, and the rest in a well-guarded house. They were interrogated, and their depositions taken down in writing.

The news of the arrest of the patriots and of the death of Villeré caused terror far and wide. They were so much identified with the whole populationas Gayarré says, "their personal friends were so numerous, their family connections so extensive, that the misfortune which had befallen them could not but produce a general sense of desolation." Well were verified the dire prophecies about Spanish cruel and despotic rule. Many in secret began to make preparations to fly to the English. Most of the houses in the city were closed; the streets were deserted and silent, save for the heavy tramp of the grim Spanish patrol.

O'Reilly pursued his programme inexorably. The ceremony of taking the oath of allegiance to Spain was sternly carried through and submitted to by the panic-stricken citizens. The trial was opened. The judges descended into the cells of the accused and forced them to answer minutely the questions they propounded. The prisoners never saw the witnesses brought against them and never knew who they

* The account of Villeré's death is given elsewhere. 
were. But the facts of the accusation were of so public a nature that they could not be denied. The accused admitted most of them and confessed their respective parts in the insurrection, resting their defense on the ground that the King of Spain had never taken possession of Louisiana, as Ulloa had never exhibited his commission; and, therefore, the colonists were not bound to receive Ulloa as the representative of His Catholic Majesty, but had the right to treat him as an intruder and impostor and expel him from the province. Also, as the colonists had never taken the oath of allegiance to the King of Spain, or been released by Aubry from their oath to France, it followed that the inhabitants, not having become Spanish, had remained French.

The French laws had never been repealed and they claimed the right to be tried and judged according to the principles, forms and usages of French jurisprudence; and by tribunals and authorities competent to take cognizance of their offense at the time it was committed.

Foucault declined to answer when interrogated, on the ground that whatever he had done was in his official capacity as Intendant of the King of France, and that he was answerable to his government alone, taking exception to any jurisdiction of the Spanish tribunal for acts which he had done officially. He was willing to stand his trial in France and repeatedly asked to be sent thither. This was accorded: he was shipped to France, where on his arrival he was thrown into the Bastille. In Louisiana Foucault's reputation has suffered the penalty 
of the infamy to which the Spanish judge condemned that of Villeré. Madame Pradel shortly followed Foucault to France.

The prosecuting attorney at the trial of the colonists was the Licentiate, Don Felix del Rey, a practitioner before the royal courts of St. Domingo and Mexico. In the long documentary report he made of the trial, he blames Lafrénière as chief instigator of the conspiracy, and complains of his deportment. As he truthfully says, if the Attorney-General had followed the example of Aubry, the rebels would have been constrained to do the like.

By the 24th of October the Court came to the end of its elaborate formalities and found the prisoners guilty. O'Reilly, as its President, pronounced and signed

"the judgment, condemning Nicolas Chauvin, de Lafrénière, Jean Baptiste Noyan, Pierre Caresse, Pierre Marquis, and Joseph Milhet to the gallows, which they have deserved by the infamy of their conduct; to be led to the place of execution mounted on asseswith a rope around their necks, to be hanged and to remain suspended until further orders."

Doucet, Hardy de Boisblanc, Masan, Jean Milhet and Pierre Poupart were sentenced to six years of imprisonment and perpetual exile from Spanish dominions. All printed copies of documents relating to the insurrection were to be burnt by the common hangman. Passionate appeals for mercy were made to O'Reilly by the women of the colony. Loyola, Gayarré and Navarro joined their intercessions, to no effect. The sentence was carried out the next day. At three o'clock of the afternoon the five prisoners, their arms well pinioned, were conducted to the barracks yard. 
"They were well dressed," writes the gossipy Baudry de Lozières, and perfectly calm and self-possessed; conversed with one another as they went along, looking around them kindly and returning salutes addressed to them affectionately."

Cupidon, a slave, overcome with emotion, rushed forward and threw himself into the arms of his master, Caresse, shedding tears and embracing him. His master returned his embraces, told him to be calm, and freed him publicly, exhorting him not to misuse his liberty.

The space for their execution was guarded by a large force of Spanish soldiers, forming a square. The prisoners were conducted to the center. A bench had been placed for them, but they refused to sit down. Their sentence was read to them in Spanish and French. They refused to have their eyes bandaged. "I have braved death too often," said Marquis, pushing the hand of the Spanish officer away, "to fear it now." Lafrénière enjoined upon his son-in-law, Noyan, to send the scarf he wore to his wife, that she might present it to her son when he became a man. With his finest Louis XIV manner, he faced his executioners, gave, himself, the word to fire, and fell, shouting with his last breath, "Je suis Français!" De Noyan, Milhet, Marquis and Caresse died in their uniforms.

The wives and families of the patriots, with the good Ursuline Sisters, were on their knees before the altar in the chapel of the convent, which adjoined the barracks yard. When the shots rang out on the other side of the chapel wall their screams pierced the air and they fell prostrate on the floor.

The day after the execution the six sentenced to imprisonment were sent to one of the forts at 
Havana. The property of all was sequestered. According to O'Reilly's report, he was satisfied that the insult to the King of Spain had been wiped out.

The Cathedral archives, kept with minute precision, contain no record of the burial accorded the patriots. It is not known where they were buried, or even if they were accorded Christian rites. Tradition supplies what seems only a pious hope, that Father Dagobert, the good French priest of the Cathedral and Vicar-General of the province, who was in hearty sympathy with the patriots, secretly had their bodies conveyed to the Cathedral precincts and, during the night, had them buried in holy ground, but the spot was never marked.

O'Reilly, it is said, wished to engage Cupidon for his servant. "What, serve the butcher of my master! Heaven forbid!" was the negro's reply. Lafrénière's slave, Artus, who had a fine reputation as a cook, was sent for by O'Reilly, who told him: "You are the slave now of the King of Spain; I will take you for my cook." "Beware!" said Artus. "You are the assassin of my master! I would poison you!"

A wandering rumor from the past is still to be met in New Orleans historical circles, that a very old Creole lady, who lived in Dauphine Street, about 1830 , in the greatest seclusion, and who was known as "Madame Boisclair," was in reality the widow of Lafrénière. To protect her privacy she had dropped the celebrated name and taken refuge in that of one of the four Chauvin brothers who had followed Bienville to Louisiana.

This explains Bernard Marigny's statement in his historical Memoirs. He relates what he seems personally to have heard: 
"To move the heart of this 'Cannibal' ( $O$ 'Reilly), Madame Lafrénière after stating to him that she was the granddaughter of the Chevalier d'Arensbourg, one of the heroes of Sweden and former aide-de-camp to Charles XII, . . . represented to him the horror and humiliation that would be inflicted upon her noble race, upon the old companion in arms of Charles XII. 'My grandsire,' exclaimed the noble woman, 'will die of shame and grief! Do not disgrace us by an infamous punishment!' 'You may retire, madam,' answered O'Reilly, 'I will take your prayer into consideration.' Accordingly, the mode of execution was changed."

Aubry left Louisiana for France. His steamer was wrecked in a storm as it was entering the Garonna and he perished with it. "His end," says Gayarré, "was looked upon as an act of retributive justice by Heaven!"

Lafrénière's plantation on the Mississippi, above the Boré place, lay just above the Audubon Park of to-day. It passed into the hands of Le Breton, the husband of one of his daughters. A son of this Le Breton married a daughter of Boré and thus became related to Charles Gayarré, whose mother was the wife of Carlos Gayarré, the son of Ulloa's Contador.

France thrust a last stab of disappointment into the heart of Louisianians who, with despairing love, still clung to the hope that the mother country would make at least a gesture of pity towards them, but a mere ripple of excitement, and nothing more, passed over the French Government councils when the news came to them. The Spanish Government sustained O'Reilly who, in true Spanish conquistador style, had laid the body of a defenseless country weltering in its blood at the feet of His Most Catholic Majesty. In Louisiana, Time, the great obliterator of mortal misdeeds, has never been able to efface the 
memory of the tragedy. The soil that drank in the blood of the patriots has given it back in the flowers of immortality that bloom around their names.

The great Chauvin family overlived the Spanish rule, carrying their fine heredity of sturdy patriotism into the vitality of the American Domination. In New Orleans, the name still lives and is met in the families of Villeré, La bedoyère Huchet de Kernion, de Boisblanc. Le Breton, and many others. 


\section{CHAPTER XI}

\section{LABEDOYĖRE HUCHET DE KERNION}

\section{THE old New Orleans name of Huchet de Kernion}

$\mathcal{I}$ is constantly met to-day in the current ways of social and business life. It always arrests the attention to the bearer of it and elicits comments of respect. To trace its source one must go far back into history.

To quote the genealogical records of the family, compiled by a representative of it to-day:

"The Huchet de Kernion family of New Orleans is one of the youngest branches of a memorable tree, whose origin is lost in the darkness of ages. The name is Breton Bretonnant, whether it descends from Huchelin de Clamban, the gallant knight who took part in the Combats des Trente in 1530, in the celebrated championship fight between Ploermel and Joselin in Brittany, or whether, following the records in the Bibliotheque Nationale, the fou uder of the family was Hugues de Horne, of the famous Horne family of Holland, who settled in Brittany in 1295, changing his name from Horne to Huchet, is yet to be determined."*

"The first authenticated founder of the family," to quote again from the records, "is Bertrand Huchet who lived in 1415, Keeper of the Seals of John, Duke of Brittany, and also his ambassador to England." His coat of arms bore three hunting horns or Huchets sables, on an argent field. In 1420 he married Jeanne de la Bedoyère, heiress of the

* Kindly loaned to the author by Georges Charles la Bedoyère Huchet de Kernion, a well-known authority on Louisiana genealogy. 
noble name and lands of the La Bedoyères, and he annexed her arms, "six pierced billets on an azure field" to his "three Huchets sables." Her name has been transmitted to his line, which is known to-day as the La Bedoyère Huchet de Kernion branch.

In the nineteenth century, the glory of the name shone out in the person of General Charles Angelique de la Bedoyère who, like the great Marshal Ney, was executed under the restoration for his desertion to Napoleon. He was on the point of making his escape to the United States, but not being able to resist the temptation of bidding his wife farewell, he turned back and was seized at the door of her dwelling

Jean François Huchet de Kernion was born in Rennes in 1604. Being the youngest son of the family, and having no share in the paternal estates, he was destined for the priesthood. Instead of this, he married Marie Léonore de Boisdonet, of an old Breton family, and settled in Quimper about 1650.

There his five children were born and in course of time were married into good old Breton families. The eldest son, who married Catherine Bouillot de Kergadon (forming the branch of Kerourin), was the grandfather of René Theophile Laennec de Kerlouarnec, the celebrated French physician, inventor of the stethoscope, to whom a statue has been erected in his native city of Quimper. The youngest son, Pierre Huchet Sieur du Rest, married twice, and it is from his second wife, Thomase Réné Guesdan de Keravel, that the Louisiana branch of the Kernions descends. But it must not be forgotten that, through his first wife, Renée Salaun du Rest, he became the uncle of the celebrated hero of France 
-la Tour d'Auvergne, surnamed by Napoleon "the first Grenadier of France." One of the proudest traditions of the family to-day, however, is the proof they made under the Revolution, of their loyalty to their Church and their King-giving up their lives unflinchingly to the guillotine.

Jean François Huchet, Sieur de Kernion, the first of the name known in Louisiana, was born in Quimper in 1700; he was the only son of Pierre Guillaume Huchet and his second wife, Thomase Rénée Guesdan de Keravel. After a youth spent in Quimper, he embarked in 1720 for Louisiana as an officer on the vessel, "La Loire," which was bringing settlers to the concession of "Ste. Reine," one of the largest grants of Louisiana land made by the Company, situated on the Mississippi above Baton Rouge.

Louisiana was then in its period of greatest inflation under John Law, and the "Mississippi Bubble" was glittering in the horizon of French speculators. After an unsuccessful trial of Périer as Governor, Bienville had been put in charge of the colony once more, and was engaged in the effort to end the Natchez War on terms the least disastrous to France. Huchet de Kernion does not figure in the list of his officers, either civil or military. The first mention of his name occurs in 1729; he is mentioned in the census as living with M. Petit de Levillier, officer of the company, on the plantation of "Petit Coulange" on the left bank of the river, going up.

According to the family tradition he brought with him from France the voluminous pages of the Kernion record existing to-day, comprising patents of nobility, titles, baptismal and marriage records and 
settlements reaching back fourteen generations to 1240 , even to the divine nimbus surrounding the name of St. Louis. His marriage in 1736 in New Orleans, with Jeanne Antoinette Mirbaize de Villemont, Widow Rivard, is the first important item concerning him in the Louisiana records of the family.

Jeanne Antoinette Mirbaize de Villemont was the daughter of Henri Martin Mirbaize (or Mirbois), Sieur de Villemont, a native of Poictiers, and of Antoinette Fourier. The Sieur de Villemont, a lieutenant in the French Army, came to Louisiana on the ship "Deux Freres," in 1719, accompanied by his wife, Antoinette Fourier, and his two daughters, Jeanne Antoinette and Marie Anne, and bringing twelve laborers for his concession, which was located on the Ouchita River, one hundred and twenty leagues from the capital.

Gayarré recounts a stirring episode in 1722 of which Lieutenant Villemont was the hero. Stationed at Fort Toulouse, in the Alabama district, in command of twenty-six soldiers, his men were rendered desperate by their hunger in a period of famine and revolted, killed their captain and started to escape to the English, in the Carolinas. Villemont, having escaped from them to the Indians, succeeded in raising a party to join him in pursuing the deserters, who were recaptured after a bloody combat.

Marie Anne de Villemont married Sieur François de Caue. Jeanne Antoinette married, in 1730, Antoine Rivard, son of Antoine Rivard, one of the original settlers in Louisiana, whose plantation is shown on the earliest maps of New Orleans on the Bayou or "Ruisseau" St. Jean. The Rivard act of marriage is one of the earliest records in the Cathedral 
register. Two daughters were born: Jeanne Antoinette and Marie Françoise. The latter died unmarried; the former married Sieur Christophe de Glapion, officer in the French Army, son of Charles de Glapion, Seigneur de Mesnilaganchie in Normandy, an illustrious family with titles of nobility dating back to 1508 . The marriage was celebrated in 1757 , on the old Rivard plantation on Bayou St. Jean, which was then known as the plantation of Huchet de Kernion.

The wealth of the Rivards was in its day a proverb in Colonial New Orleans, and it is still repeated currently among the descendants of the old families. The marriage of the Widow Rivard with Huchet de Kernion must have been considered an event of great social importance in the entire city. The names of the witnesses inspire respect two centuries afterwards. Bienville, Chevalier de St. Louis, Governor of Louisiana; de Noyan, his nephew, Chevalier de St. Louis and his wife; Fleuriau, Attorney-General; Salmon, Commissary and Intendant; Renaud d'Hauterive; Madame Veuve Déléry; Françoise de Villemont, sister of the bride. Only one child was born of this union, Jean Réné Huchet de Kernion.

Bienville having retired to France, and the Company of the West having retroceded Louisiana to the French Government, Vaudreuil was appointed Governor, giving to Louisiana an administration considered still the most brilliant in her annals. His wife, the handsome and elegant Marquise de Vaudreuil, is entitled to share his honors in history. She may be said to have created society in New Orleans, gathering about her the beautiful women 
of the city (among them we may imagine the beautiful and rich Madame Rivard) in her little "government court," training and polishing them and converting them to the adoption of an etiquette so perfect in its rulings that it reigned triumphantly during the Spanish and American administrations, and remained in force two centuries later, as New Orleans grandmothers of to-day love to recall.

The Marquise, who adored festivities, held receptions where she entertained with music and theatricals. The first drama ever composed in Louisiana, an Indian story, was written for her by a brilliant young French officer of her court, LeBlanc de Villeneuve; and it was acted before her in her drawing-room. The portrait of the author is still preserved as an Indian, the hero of the play. During her reign the ladies of New Orleans advanced very far from colonial simplicity of manners and dress, and indeed went so far in sophistication as to order their carriages from France.

In 1735, Vaudreuil was appointed Governor of Canada, and Louis Billouart de Kerlerec was named to succeed him in Louisiana. A Breton, born in Quimper, and therefore a fellow countryman and townsman of Kernion, Kerlerec found in him a friend during the hard trials of the most uneasy administration known in colonial Louisiana. To the constant menace of Indian troubles and British aggression was added the keen opposition of a private enemy-his Commissary, Rochemore, who, with vindictive persistence, not only thwarted his superior at every turn, but formed with the citizens a cabal against him, and kept up a constant current of charges against him to the Minister in France. 
The doughty Breton, who had begun life at fourteen on the sea, fought as sturdily and obstinately against his domestic enemies as against Indian and English intrigues. He fought even against the poisonous venom of the libels of Madame de Rochemore, whom he calls "the worst woman the earth has ever borne, the most perfect emblem of avarice"! He, nevertheless, was recalled in 1763, and was imprisoned in the Bastille until he could disprove the charges against him. Huchet de Kernion was active in Kerlerec's behalf, and he signed, if he did not write, the strong protest sent to France against Rochemore.

On recommendation, Kernion was promoted in 1760 from Associate to Titular or Active Councillor, in the Superior Council, thereby enabling him to take an important part in the great event so soon to follow in Louisiana. This was the transfer of Louisiana by France to Spain. The survivors among the men who had followed Iberville and Bienville to the discovery of Louisiana had entered upon the tranquil enjoyment of the well-earned rest and prosperity of their old age. Their sons were in the full strength of a hardy middle age, when this political chasm opened at their feet.

The story need not be repeated except as to the rôle played by Huchet de Kernion. Ulloa had arrived and was assuming the reins of government despite the public protest of a first indignation meeting of Louisianians. A larger meeting was then called and a still stronger protest, signed by more than five hundred of the leading citizens, was presented to the Superior Council, asking the expulsion of Ulloa from the colony. This being read, it was, 
on motion of Lafrénière, referred to the Councillors, Huchet de Kernion and Petit de Launay, to be examined by them and reported upon. The next day, the Council raised to its full strength by appointees to fill the place of absentees, met to hear the report. Upon due consideration of it, Kernion and de Launay wrote a strong endorsement of the petition, which the Council voted unanimously to sustain; and in consequence the Spanish Governor was expelled from the colony.

The inevitable result followed. O'Reilly was sent by Spain with a military force to "pacify the colonists," as it was termed. This was done by executing and banishing the leaders of the revolt. Huchet de Kernion who, besides his official act, had attended all the public meetings and put his name to all the petitions against Spanish rule and the justicative Memorial of the expulsion of Ulloa to the government in France was, strange to say, never called to account by the Spanish authorities with the other patriots, nor was his name mentioned once as a "rebel" by Père Antoine, the priest.

But he did not long survive the bloody death of his friends and relatives. Bent with age and sorrow, he died before a year had passed, leaving one son, Réné Huchet de Kernion, who was born in 1739 on the plantation on the Bayou St. Jean. Like his father, he was an officer in the colonial troops, and was retired with the other French officers by order of the King when the colony passed over to Spain.

In 1767, two years before the Spanish Domination, he married "the high and well-born" Louise Constance Chauvin de Lery des Islets, daughter of Antoine Chauvin de Lery des Islets and of Charlotte 
Faucoh du Manoir, thus entering the great family of the Chevalier d'Arensbourg and becoming a cousin of the famous patriot Lafrénière and of Joseph Roy de Villeré. His witnesses present us to the most distinguished citizens of the city at the time: the Chevalier de Glapion; Trudeau, Captain of Infantry; de Villemont de Kernion, and all the Chauvins; Boisclair; des Islets; de Lery; Hubert Bellair; de Mazan; Dreux.

With other French officers and children of Louisiana patriots, Huchet de Kernion became in time reconciled to the Spanish rule. During the administration of the greatest Spaniard who ever came to the colony, Galvez, himself the husband of a Creole lady, and through her connected with many distinguished Creole families, he was appointed by the Spanish King Alcalde Ordinaire, the first office in the Cabildo. It was a position of importance, dignity and distinction, invested with the function of Judge and as such ranking next to the Governor of the province.

It is noticeable that in official documents he, like his father and grandfather, adhered to the old Breton custom of using the barred $\mathrm{K}$ - in names beginning with Ker; signing himself Knion Kernion.

He married a second time; uniting himself to Marie Joseph Modeste du Verges de St. Sauveur, daughter of Bernard du Verges de St. Sauveur, of a distinguished family of Bearn who came to New Orleans in the early days of her history, becoming Chief Engineer of the province. He showed himself to be an able officer under Bienville during the Natchez War, when he surveyed a road for the 
passage of French troops into the Chickasaw country. He also made an important report to the government on the mouth of the river, in $\mathbf{1 7 4 5}$.

Pierre, his son by his first marriage, married Marie Geneviéve Claire Jumonville de Villier, the daughter of a retired Spanish officer. From this union descend the Kernion family of to-day. Celestine, his eldest daughter, became the first wife of Charles LeBreton des Chapelles, the grandson of Etienne de Boré. Her sister, Marie Rosilde, became LeBreton's second wife.

Chrispin Charles LaBedoyère Huchet de Kernion, born in 1796, became a planter and was living on the old place on Bayou St. Jean, when in 1815 the British Army seemed about to overwhelm New Orleans. He shouldered his musket and walked out to the field of Chalmette. It is related of him that, at the time, he was physically so weak he could not carry his heavy "muzzle-loader" all the way, and that his older and stronger brother had to carry it for him.

He married in 1822 Euphémie Arnill Lambert, the daughter of Pierre Joseph Lambert and Marie Constance Wiltz. The miniature of the two, preserved in the family archives, represents faces of youth, beauty and intelligence. Euphémie is especially distinguished by the pensive, mysterious expression of her beautiful eyes. At her death, among her private papers was found the pretty legacy of a large portfolio of music, songs and verses, copied in her exquisite handwriting, collected as she went along from the society that she loved and that loved such things-a private labor of love, the patient result of long hours of rapt application and 
withdrawal from the busy world of plantation life and the domestic cares of a family of nine children.

Her youngest son, Anatole LaBedoyère Huchet de Kernion, married Fannie Evelina Campbell (according to the record a member of the Argyle family), adopted daughter of Samuel J. Peters, Jr., whose wife, Aspasie de la Villebeuvre, was her second cousin. He lived to add one more episode to the history of his ancient family, for he served from the beginning to the end of the Civil War, in the Twenty-third Louisiana Regiment, and was one of the heroic soldiers who gained glory for their cause in the terrible siege of Vicksburg.

On his return, he found that the lot of the vanquished severed him from the past wealth of his family, but not from its proud fortitude and its capacity for business. He "did not stoop or lie in wait for wealth or honors, or for worldly state," as many did in the sad period of demoralization that followed the Civil War, but, courageously facing the doom he had incurred, he sold his ancestral plantation and heroically engaged in a mercantile pursuit, serving faithfully for twenty years in the ranks of the employees of the old Canal Bank.

George Charles Huchet de Kernion, the archivist, the kind contributor of these notes, is his son. 


\section{CHAPTER XII}

\section{DE LIVAUDAIS}

$\mathrm{H}_{\text {de Livaudais, Esnould Dugué de Livaudais.* }}^{\text {SNOULD DE LIVAUd }}$ The sturdy family tree of the Livaudais was rooted in the strong soil of Brittany. Olivier Esnould of Paramé, 1510, is the first name it bears. Olivier Esnould, 1534; and François Esnould, 1559, continue the record. With Briand Esnould, 1604, the family life begins in St. Malo, where it remains until 1695. Jacques Esnould de Livaudais, Chevalier of St. Louis, was the first of the family in New Orleans. He was the son of Jacques Esnould de Livaudais of St. Malo, who married Marie Guillette le Jaloux, 1695; therefore he had the good fortune of being born during the glorious period of St. Malo's history. As a child he heard the ringing of the city bells and firing of cannon in honor of the great victories of the mighty sea captains against the English and Dutch vessels. He must have seen the immortal "sea wolf," Duguay Trouin himself, bringing into port his prizes. His own uncle, Lavigne Voisin, was one of the celebrated corsairs of the day. A lad of such a city, such a family and such a period could not prove disobedient to the heroic spirit about him and within him.

Following the example of a brother, he embarked

* Genealogy of the Livaudais family arranged from authentic records, by Alfred Fortuné Livaudais. New Orleans. 
with Lavigne Voisin to make his apprenticeship as a seaman. The good termination of his apprenticeship opened his way to a position on a ship of the Company of the Indies. The proof he gave of courage, capacity and good seamanship recommended him to the directors of the Company, and, in 1720 , before he was twenty-five, he was made First Lieutenant on the vessel "La Découverte," with a salary of two hundred livres a month and a "gratification" of two thousand livres on his return, a brilliant testimonial in that day of his worth to his employers. He continued his East India voyages for twelve years to such complete satisfaction of the directors that they transferred him to an important post in Louisiana. He was made Pilot of the Port of New Orleans.

The explanation is hardly needed that, after the founding of the city upon the Mississippi, the problem that confronted its founders was not its maintenance as a city but as a port. A city upon the banks of a river not navigable to large vessels would have been indeed a disastrous speculation for them. Bienville, as we know, had gained the directors of the Law Company to his project of founding a city that, he affirmed, should be a dominating port on the Gulf of Mexico for France, as well as an outlet for the trade of all the interior of the continent. He had maintained an obstinate contention with the Council Board at Biloxi to prove the correctness of his calculations; the Council Board maintaining as obstinate a fight in favor of Mobile or Biloxi as the capital port. It was not until the city itself was laid off and the settlement of it begun that the Royal Engineer, de la Tour, practically ended the discussion 
by coming over from the opposition to the side of Bienville and in proof of the feasibility of the latter's assertion sailed through the mouth of the river himself on the loaded vessel "Aventurier," accompanied by his assistant, de Pauger.

The letters of Bienville to the directors in France, the reports of de la Tour and de Pauger, and the instructions of the directors to their engineers, give in detail the interesting history of their strenuous efforts to solve the stupendous problem before them - the problem that was to be the mythical dragon of the nineteenth century to river commissions and engineers of the United States. The changing channel, the shifting sand bars, the mud lumps, and drift wood held in constant menace over the city for a century and a half the doom prophesied by its enemies at the Council Board at Biloxi.

De Pauger, with a masterly map of the Passes and the table of his continuous soundings of the channel, was the first one to approach the problem with systematic thoroughness; but he died, leaving only suggestions of a remedy behind him. Among them, it is interesting to note a foreshadowing of Ead's scheme-the closing of two of the Passes, and the deepening of the third by means of jetties, to be made of sunken vessels and driftwood.* In the time of Bienville and succeeding French Governors, a pilot was stationed at the Balize, whose duty it was to keep a record from day to day of the depth changes in the Passes and of the shifting of the channel, and to pilot the vessels arriving from France or elsewhere.

In 1734, Bienville, who had succeeded Périer * "Voyages et Découvertes." Pierre Margey. Vol. VI. 
as Governor of Louisiana, wrote to the Minister in France:

"We have had the honor, M. Salmon (the Commissary) and I, to write to you in favor of M. de Livaudais, sent by the King of Louisiana as pilot. He should be made Captain of the Port."

In the letter to which Bienville alludes, he writes that he "particularly recommends M. de Livaudais as an officer to be retained."

A marginal note says, "he is a nephew of Lavigne Voisin, a famous corsair of St. Malo."

Following this, Livaudais was made "Captain of the Port," a title that should be rendered "Captain or Surveyor of the Ports," for it comprehended the charge of all the ports of Louisiana on the Gulf of Mexico and the Atlantic Coast.

In a voluminous report on the river written in 1738, Bienville and Salmon, his commissary, give an account of the delay, danger and difficulty met by vessels entering the river. He adds:

"The Sieur de Livaudais, who has been a navigator for thirty years, has been up to the present time of the greatest service in getting vessels through the Passes, and has by his prudence saved them often from accidents. After having served on the corsairs of St. Malo, he was transferred to the Company of the Indies. He deserves, and it would be proper to accord him, a commission."

In 1760 , Kerlerec, in pressing need for powder, sent Livaudais on the armed transport, "The Opal," to Vera Cruz for a supply. He left in March and returned in September with the powder, having encountered four British vessels, one of sixty guns. In the chase that ensued, "The Opal" managed to keep her distance ahead, until she arrived in sight of the Balize, where Livaudais, determined not to lose his powder, took the daring risk of bringing his vessel through the Passes at night, although the water was low at the time. 
In 1733 Livaudais married, in New Orleans, Marie Geneviève de la Source, "daughter of an honorable family of Mobile." From this marriage issue the many members of the Louisiana family of the Livaudais that fill the branches of their great genealogical tree. There is no explanation given of the subsequent division of the family name into Beaumont and Dugue de Livaudais other than the suggestion that it came or was assumed from a land title.*

There is no Beaumont recorded among the colonial French officers in Louisiana, and the only Dugué was Jean Sidrac Dugue, of Canadian origin, who styled himself Boisbrillant. $\mathrm{He}$ was a brilliant officer under Bienville's first settlement at Mobile. It is constantly stated that he was a cousin of Bienville, although there does not appear to be any connection with the Lemoyne family. According to tradition the first Dugué de Livaudais had seventeen children, who married early into the prominent colonial families and left behind them descendants numerous enough to clothe the branches of the family tree with leaves as close set as a live oak in spring. The record, however, limits its list to the eldest sons: François Esnould de Livaudais, born in 1736, who married Pélagie de Vaugine; and Joseph Esnould Dugué de Livaudais, who married Jeanne Fleurian de Morville.

The eldest son of François de Livaudais and Pélagie de Vaugine was François Esnould de Livaudais, who married Charlotte des Islets de-

* In 1728, the Dugués, "famous for their wealth," were established on Bayou St. Jean. "The Louisiana Historical Quarterly. Vol. I, No. 3. 
Lery. He appears to be the Livaudais who shared with Marigny the honor of being the largest landowner and wealthiest citizen of New Orleans of his time, and of entertaining the Royal Princes of France on their visit to the city, and, with Marigny, making a generous loan of money to them, although Marigny alone is credited with this.

His son, bearing the same name as himself, married the great heiress of the city, Céleste de Marigny, daughter of Philippe de Marigny, from whom she inherited what would to-day be estimated as fabulous wealth in property situated in the upper portion of New Orleans, which, joined to what her husband already possessed, made them the owners of all the "American" quarter, or uptown portion of the city, just as the Marignys remained the owners of the lower, or "Creole" quarter. The American quarter was then an undeveloped tract of land some of whose great oak trees may still be seen, the aborigines of the primeval forest, in isolated groups standing here and there, in proud defiance of property lines and street demarkations.

In recent years a lawsuit has brought the history of a part of the property of Céleste de Marigny de Livaudais to mind. Pierre Marigny held it under a concession from the French Government. It passed from Céleste de Marigny de Livaudais to her heir, Jacques Enould de Livaudais. It was one of his heirs who conceived the idea of building a military academy, or Prytaneum, on two squares of it, bounded by St. Charles and Prytania, Melpomene and Euterpe Streets. The academy project was abandoned in course of time; the name of the street, Prytania, alone commemorating it. 
The heirs sold the land more than a quarter of a century ago. Celeste, the widow of François de Livaudais, with what remained of her magnificent fortune, retired to Paris where, as the Marquise de Livaudais, she lived until the middle of the eighteenth century, receiving to the last with open arms her friends and relatives from New Orleans, and entertaining them in the style of generous hospitality to which, as a Marigny, a de Livaudais, and a New Orleans woman, she felt herself, as it were, commanded.

Unfortunately for so distinguished a family, the genealogical tree gives no other information than the record of births, marriages and deathstoo long a list to insert here. But we may cull a few of the names bracketed together along the branches: François Enould Dugué de Livaudais and Aline de la Chaise; Henri Enould Dugué de Livaudais and Celestine Dreux; Sophie Enould Dugué de Livaudais and Pierre Auguste de la Chaise; Charles Jacques Enould de Livaudais and Eulalie Léocadie LeBreton des Chapelles; Jacques Philippe Enould Dugué de Livaudais and Rose Victoire Voisin; Jules Barth Enould Dugué de Livaudais and Marie Zunia Trudeau; Louis Adolphe de Livaudais and Irene Eulalie Frederic de St. Férol.

The good old names are repeated over and over again; the good lives that flow from them appear also in a monotonous repetition of able men and beautiful, noble-looking women. Joseph François Enould Dugué de Livaudais, born about 1784, was the first to sign and call himself François Dugué. He married Jeanne Marie Plique, and had, like his remote ancestor, a goodly number of children, who all are known as Dugués. 
Henri Philippe Dugué, the late distinguished lawyer, and Charles Oscar Dugué, a local poet of noble proportions, were his sons.

Henri Philippe Dugué married Celestine Dreux, the sister of the Confederate hero, Charles Dreux. Caught in the whirlpool of the Civil War, he was forced to take refuge in Havana. He left his native city a man of wealth; he returned, like most of his confreres with nothing left of all his former possessions except his good reputation as a lawyer and two old slaves who, although free, insisted upon devoting to him their services until their death. Children and grandchildren survive him to carry on his good name and tradition.

A last reminiscence is given by an old writer and lover of New Orleans.*

"There was but one highway leading above the river, and this was 'The Tchoupitoulas Road.' Along this road commencing about Delord, the upper extremity of the Faubourg Ste. Marie, and extending toward the magnificent Livaudais plantation, was a succession of beautifully located villas and agricultural establishments. All along Tschoupitoulas Street there ran a low levee planted with willow trees, and during the season of high water, when the batture then forming was thoroughly immersed, the long western keel boats and barges, as well as the unseemly flatboats, or chalands, would make fast to these trees and thence discharge their cargoes.

"After the receding of the spring and summer floods, these flatboats, of enormous construction and unfit for a return voyage, would be left high and dry upon the batture front, and then be broken up for fuel and building purposes. The strong side pieces, or gunwales, were used in the suburbs as footpaths or side banquettes $\dagger$ in lieu of our present brick-paved sidewalks. Upon these wooden trails, as it were, pedestrians had to make their way through immense vacant spaces, for there were but few buildings toward the rural precincts, leading to the Livaudais plantation, which constituted that portion of New Orleans which now forms the Fourth District.

* "New Orleans As It Was." Henry C. Castellanos.

$\uparrow$ Sidewalks in New Orleans are still called banquettes. 
"On the way to that wealthy estate, the river front was lined with a continuous series of delightful rural residences, surrounded with orange hedges, orehards and well-tended gardens. The great Maearty crevasse, in the spring of 1816 , submerged the rear portions of the numerous plantations. The Livaudais estate was one of the heaviest sufferers from this calamity. A great misfortune this, for Mr. François Livaudis. The planting of a crop or several bundred hogsheads only yielded twenty-eight hogsheads of sugar; and the splendid residence, commenced about that time, was never finished, affording even to these latter days the spectacle of an abandoned castle, that went afterward by the name of the 'Haunted House' (near Washington Avenue).

"The value of this plantation became greatly enhanced on account of its being raised several feet by the remaining deposit, or alluvial settlement, of the Mississippi water. A company of speculators acquired by purchase a great part of this estate, which is now the beautiful Garden District, and which took its rise from this very circumstance of the overflow." 


\title{
CHAPTER XIII
}

\section{SONIAT DU FOSSAT}

\begin{abstract}
A CHARMING bit of family reminiscence is $A$ conveyed in a few simple lines written by the late Charles T. Soniat du Fossat for the Louisiana State Historical Society:
\end{abstract}

"While visiting the great Paris Exposition in 1900, I had the pleasure of receiving a charming invitation from my cousin, Henri de Pousargues, a General of the French Army, the owner of the Chateau du Fossat, the cradle of the family of Soniat du Fossat." He goes on to describe it: "In a charming valley of the picturesque stream, the Lot, near its juncture with the Garonne, the château appeared a very citadel of strength. Built of solid stone and masonry, it had withstood well the ravages of time. The grand old oaks at the entrance-hoary with age-seemed to have braved numerous tempests. It was in 1538 that my ancestor, François de Saunhac de Belcastel, took possession of the chatteau, which has been continuously owned by the family ever since."

Taken into the spacious rooms where the heirlooms of the family were stored, our writer found among them papers and documents relating to the American branch of the family, which his kind host allowed him to bring to New Orleans with him. Among them was an old and faded manuscript, written in French, entitled "A Brief History of Louisiana." The document was unknown to Mr. Charles Soniat du Fossat, a student himself of Louisiana history. The page where the name of the author should have been signed was torn; the handwriting was peculiar and difficult to decipher. 
$\mathrm{He}$, nevertheless, translated and published it; sought and found the name of the author, who was the Chevalier Guy Soniat du Fossat, the first of his name in Louisiana and the founder of the American branch of the family. Born in the château in 1726, he entered the French Army as volunteer in 1746. By 1747 he was a lieutenant in the Regiment of Monaco and in 1748 was wounded in the siege of Maestrich.

In 1751 , during the reign of Louis $\mathrm{XV}$, when the Marquis de Vaudreuil, Governor of Louisiana, made an appeal for troops, France sent a reinforcement of five thousand men. Among them was the young lieutenant, Guy Saunhac du Fossat. He was stationed in New Orleans. Following the example of young French officers of family, he married shortly after his arrival in the city, taking as his wife Claudine Dreux, the daughter of one of the most prominent families of the city-that of Mathurin Dreux, the "Sieur de Gentilly," the aristocratic and wealthy planter on the Bayou St. Jean.

Being an engineer of ability, Soniat was appointed a captain in 1759, and sent to Illinois to construct and repair forts. Owing to him, Fort Chartres and the Kaskaskias were put in a state to ensure the protection of the Western colonies for years. He rendered good service in the colonies against the English, and was recommended by Kerlerec for the Cross of St. Louis. It is not definitely known when the ancient name of Saunhac was changed to its Louisiana version, Soniat.

He was recalled to New Orleans in 1761, where he continued in the service of France until 1766, when Ulloa came to Louisiana to take possession of the 
colony in the name of the King of Spain. In accordance with a permission granted by the King of France, in 1769, he entered the service of the King of Spain in Louisiana. After O'Reilly had assumed control of the colony, in 1769, he was made captain in the Battalion of Louisiana and was therefore one of the officers who, according to Gayarré, impressed O'Reilly so forcibly with their distinction of appearance that he regretted his inability to take some of them with him to Spain, as specimens of the new subjects acquired by His Catholic Majesty

In 1772, Soniat was retired from active service and was appointed Alcalde by Unzaga. Returning to civil life he bought in 1778, from the Ursuline Nuns, the plantation seven miles below the city of New Orleans, which he afterwards exchanged with Bernard Marigny for the one above the city on the river still retained in the family. Marigny eventually sold the tract to Jacques Philippe Villeré, and it is known in history as a part of the field of Chalmette, upon which was fought the Battle of New Orleans.

In 1786 Soniat was reappointed Alcalde by Governor Miro, and in 1794 he died and was buried in New Orleans. From his marriage with Françoise Claudine Dreux he had three sons: François Guy Soniat du Fossat, who married, first, Anne Arnout; second, Louise Duralde; Joseph Soniat du Fossat, and Juan Baptiste, under whose name the significant and discreet record is written-"Il réussit auprès de la Reine d'Espagne." He had (consequently we may assume) to leave Spain and come to Louisiana in 1800 . He died unmarried.

François Guy, the eldest son, a soldier like his 
father, followed the campaigns of Galvez against the English. He was present at the capture of Baton Rouge and Manchac, and witnessed the storming of Mobile and Pensacola. For signal bravery on the field of battle he was promoted to lieutenant in the Battalion of Louisiana in 1780, after which he was recalled to France by the death of his uncle, le Baron Jean du Fossat, to take possession of the château, with the title of Baron.

He presented a memorial to Louis XVIII, asking as recompense of his services the Cross of St. Louis. To support his claim, he mentions also the services rendered by his father to France; among them a "Memorial" of Louisiana. It seems doubtful whether the manuscript ever left the author's possession. It is probable that, once finished, it was laid away in the old cabinet among his family papers, and that it lay there until Mr. Charles Soniat of New Orleans discovered it.

There is no mention of it by other historians and no evidence of its ever having been read even by such meticulously careful historians as Gayarré and Martin, or by his kinsman, Alcée Fortier. The author himself quotes from no written authorities; in fact, when he wrote there would have been none available to him. He tells a plain historical story as he heard it, with a simplicity and an originality of judgment which makes him a refreshing companion over a road that has become monotonous and dusty from constant travel upon it.

The geographical description of the province with which it opens, is what we are accustomed to, except when he relates such "peculiarities" as in the village of the Cohoes, "where are to be seen tombs 
ranging from seven to eight feet long, and they seemed to have contained bodies of that size, judging by the skeletons found therein," to which he added his own version of that weird, apochryphal legend of "The Man Plant."

"In going up the Missouri River, about three hundred leagues, some travelers discovered on its banks the trunk of a plant resembling a human figure. Having approached near enough they saw that it looked like the body of a woman, with arms, legs, hands and breasts. At the extremities of the hands, fingers and breasts there were filaments serving as roots, leading into the ground, and the head was crowned with a small tree, with some foliage. The travelers searched in the vicinity and found others of the same kind and after having dug to the roots of the plants, they found bodies of the same nature as the first, designating males and females. The travelers, with their sense of curiosity and wonder, brought with them to the Illinois post a few of the curiosities, which brought about several theories. Some contended that it was a root to which nature had given the form of a human figure. Others argued that they were real bodies that had been buried standing, according to the custom of certain nations, and that they had vegetated in a soil proper thereto. The first theory prevailed over the other. Awaiting further investigation which may settle the question, we had in our possession an arm from said plant, which resembled in every respect the arm of a man."

It is, however, Soniat's frank and judicial opinion upon historical events and men of his day that is of most value to the student, weary of the constant repetition of the almost mechanical opinions found in other histories.

"It was," he says, "the dissensions between Bienville and Noyan, captain of the vessels and commander of the troops, that were the cause of Bienville's failure, in his expedition against the Chickasaws and Cherokees." Of the Governors, as an observer at close range, he says, "M. de Vaudreuil was kind and peaceful and did much for public welfare. . . . M. de Kerlerec was a man full of vanity and of an intriguing and selfish disposition. . . He considered 
Louisiana as his prey and did all he could to reap all the fruits possible. . . . Under him the good will and cordiality which had existed between the inhabitants during previous administrations, vanished entirely. During the time of Bienville and Périer, those who composed the colony lived in perfect accord with one another, so much so that they seemed to form part of one large family visiting one another and holding reunions and meetings at which harmony and gayety invariably prevailed. The food products, and hunting and fishing, were in abundance. The women were neatly dressed without ostentation. Living was cheap."

His impression of Ulloa, the sinister author of Louisiana's tragedy, bears out the judgment of the "patriots" upon him, and his description of the revolt against Spanish authority is the coolestworded one of the event that we have

"Ulloa had been the traveling companion of M. de la Condamine (in Peru) but did not create the impression in any one, by his appearance or conversation, that he had taken any great part in these discoveries . . . a man of talent, very self-opinionated, incapable of putting in his official acts such care and attention as were necessary to gain the confidence of a people just experiencing a change of government.

"O'Reilly, who simulated good will towards the inhabitants (deceiving the revolutionists), arrived quietly in New Orleans, and made all preparations for disembarking, as if an army were before him, ready to oppose him. . . . He took possession of the colony, a formality which his predecessor had neglected. . . Unzaga, reputed to have been unjust in other governmental positions and who, in the beginning, had by his coarse, repellent manners given poor hopes, became popular and was well liked and applauded."

To the usual heavy historical laudation of Galvez, Soniat substitutes new and original version of his character and campaigns, written with the sharp pen of a discriminating French officer-perhaps dictated by his son who fought under Galvez.

"Don Bernardo de Galvez succeeded Don Luis de Unzaga; he was the nephew of a Minister of that name who ruled Spain and who, 
having no male children of his own, took occasion to favor his nephew, who was not slow in taking advantage of the good will of his superior. He started his nephew's fortune by sending him to Louisiana in the capacity of Colonel and Governor ad interim.

"That Minister, well posted concerning the secrets of the Cabinet, saw that Louisiana was destined to be the siege of war, and the place where his nephew could make his mark. He furnished him the means to that end in his capacity as Minister of 'Indies,' and he planned everything so advantageously that an officer with any ordinary capacity should have succeeded within a year. Don Bernardo de Galvez was subsequently appointed Governor, with full title. He had properly made use of his time in endearing himself to the inhabitants by means of flattery, caresses and even by procuring to them new pleasures. He appeared sympathetic, just and disinterested, even assisting the natives. His conduct, supported by his uncle, conciliated everybody. He was not slow in making use of all the advantages that were thrown in his path by the Minister who, ever mindful of all that could turn to his advantage, and seeing that war was inevitable with England, apprised his nephew beforehand that war would be declared; by which means, Bernardo de Galvez knew of the declaration of war in Louisiana before it was known in Madrid, and he acted in consequence.

"Galvez, having made the necessary arrangements, issued a proclamation summoning the colony to arms, and marched with his forces towards post Manchac. There he published the news of war, and by that means surprised the English, who were in possession of that fort. The latter, finding it impossible to defend that post, which was of little importance, abandoned it and retreated to Baton Rouge, which they fortified in haste, the day after their retreat. During the night, Don Bernardo de Galvez, apprised of the evacuation, disposed his troops to advantage, ordered the assault and entered the fort which had only twenty men, who made no resistance.

"The news of this conquest, conveyed to the Court under the most glowing colors, brought to Galvez the title of Brigadier. - . He employed part of the winter in making preparations for the siege of Mobile. He demanded of the authorities of Havana men and vessels for the purpose of attacking it with advantage and with all possible security. . . .

"He embarked with a small number of soldiers and inhabitants of the colony, and arrived on the ninth of March, 1780, in Mobile 
Bay, where a severe tempest destroyed several of his ships, which foundered in the pass of the bay. These ships carried many men, who spent more than thirty hours on the débris of the vessels. The calm, which came in due time, permitted the launches, or ship's boats, which had resisted the tempest, to pick up the unfortunates, who, with eyes and hands raised towards the heavens, were imploring aid and succor. Their prayers were answered and they were all saved. . . . They were landed on the coast of the bay. At that moment the army was in such a bad condition that if the English had had a single detachment on the parapets, as they should have had, they would have taken all these unfortunates that had been saved from the storm, and thereby not only would they have preserved their post but would have easily conquered Louisiana, which had been left without a defender.

"After that, there remained to the English in the Gulf of Mexico only a single possession which was Pensacola. . . Galvez was anxious to effect this conquest. He finally undertook it, and, with that end in view, sent M. Miro to Havana, to ask for all that was necessary for the enterprise. He obtained soldiers, vessels and artillery. All left in the year $\mathbf{1 7 8 1 .}$

"Galvez succeeded in passing the fort and its artillery, and landed without obstacle. The English offered feeble opposition. . . . Half of the garrison perished; the fortification, which was of wood, was burnt. . . . Galvez took possession of his conquest and came back triumphant to New Orleans. Don Bernardo de Galvez gathered all the fruits of that war. He obtained promotion from Captain of Infantry to Lieutenant-General and Viceroy of Mexico, where he died.

"When Galvez died, Don Estevan Miro became Governor of the Province of Louisiana. His solicitude for the welfare of his people, his honesty of purpose, and his sense of justice, made him an admirable Governor. He was always attentive to duty and ever ready to obtain from the Court of Spain new favors for his people. He used his best endeavors to check the evils brought about by habits of luxury, which had been allowed to spread by the actions of his predecessors. . . . M. Miro corrected as much as he could the many disorders that had crept into the community. He had already succeeded in giving splendor and éclat to all the affairs of the colony.

The author was in New Orleans when the great 


\section{conflagration occurred and gives this account of it:}

"On Good Friday of the year 1788, a fire was caused by the negligence of a woman who thought of crowning her devotion by making a small altar in her house. She left several candles burning around it and went off to take her dinner. During her absence, a candle fell on some ornaments which took fire, and the house in an instant was in flames, which communicated to the adjoining house. The wind, which was strong at the time, spread the fire to the balance of the city, which in two hours was consumed. . . .

"It would be difficult to depict the despair of the poor unfortunate persons, whose properties had suffered from the fire; these unhappy creatures who two hours before had enjoyed vast and commodious lodgings, with enough affluence to make one's life agreeable and easy, saw themselves and their children, in a moment, without resource. Some of them were obliged to take refuge in the woods, without necessary provisions and clothes. Some slept without cover under the broad canopy of the heavens. It was in that moment of necessity that the tender solicitude of Governor Miro showed itself. He opened his house to all who were seeking shelter, and he dispensed succor to the distressed families, caused the Royal stores, which had escaped the flames, to be opened; and he distributed the provisions therein contained. Recourse was had to the surrounding country for help; permits were given to vessels to bring goods from abroad; in short the Governor administered as a good paterfamilias. . . . Poverty stared the people in the face; the inhabitants were in a state of consternation; one-sixth of the citizens died.

"Governor Miro tried to divert their attention and alleviate their sorrow by his care, his attention and his purse. He gave balls and amusements in order to lessen their sorrows and to divert their minds. . . Eight hundred fine and commodious houses valued on an average at three thousand dollars each were destroyed, without prospect on the part of the owners of ever recovering anything except perhaps the bare hope of receiving some day some relief from the King."

After having spoken of Louisiana's soil, the author says of the Creoles:

"Creoles are defined to be the children of Europeans born in the colony. They in general measure about five feet, six inches, in 
height; they are all well shaped and of agreeable figure; they are lively, alert, and agile; notwithstanding the great heat of this climate, they are laborious. They are born with ambition and an honest sclf esteem. They are endowed with a natural disposition for all sciences, arts and exercises that amuse society. They excel in dancing, fencing, hunting, and in horsemanship. Nature has favored them with an active and penetrating mind; they are capable of being easily instructed. The lack of teachers renders their education somewhat incomplete, and it must be said, in all justice, that among the many qualities which they possess are politeness, bravery, and benevolence. They are good fathers, good mothers, good friends, and good kinsmen. The women besides having the qualities above enumerated are agreeable in figure and seldom deformed. They make good mothers and are devoted to their husbands and children."

The record closes all too soon at the end of the year 1791, when the administration of Miro terminated and that of Carondelet began, the author dying in 1794, during the incipient agitation that was to result in the recession of the colony to France and its transfer to the United States. The last pages of the manuscript are devoted to a description of birds, reptiles and animals of Louisiana, narrating many curious personal experiences. One of them about a crocodile seems worth quoting:

"A negro woman who was washing clothes on a bridge near the water's edge was perceived by a crocodile, which came swiftly swimming just under the surface of the water, and he tried to snap her by the hand, but she saw the creature and ran away. The crocodile, after several unsuccessful attempts, finding be could not accomplish his end, passed under the bridge and caught the negro woman's clothes from behind. Luckily I was within reach with my gun, and as she yelled, I flew to her rescue and released her from the clutches of that beast which would, beyond a doubt, have dragged her into the water but for my opportune presence and assistance."

Guy de Saunhac (Soniat) and Claudine Françoise Dreux left the following children: Françoise; Agathe 
Antoinette, who married Jean Enoul de Beaumont de Livaudais; François Guy, who married Cécile de Lassudrie, daughter of Jacques de Lassudrie and of Marguerite de Toucheboeuf; Lucie; Jeanne; Elizabeth, married to Antoine Doriocourt; Guy (Joseph), married first to Marie Anne Arnoult, second, to Louise Duralde (sister of the wife of Governor Claiborne); Marie Emilie, married to Jean Baptiste Bermudez; Catalina; Chevalier Jean Baptiste, unmarried.

The children of Guy Joseph Soniat du Fossat and Marie Anne Aenoult, were: Chevalier Guy Joseph, who died in France; Joseph; Pierre Antoine; Jean Ursin, who married Célestine Allain; François Guy.

There were nine children of Guy Joseph and Louise Duralde (the sister of Clarisse Duralde, wife of Governor Claiborne): Edmond; Charlotte Adine; Martin Valmont; Charles Meloncy; Valérie; Gustave; Célestine; Joseph Théophile; and Charles Theodore, married to Marie Aménaide Labranche, daughter of Lucien Labranche and Mathilde Fortier.

The children of Charles Théodore and Amélie Labranche were: Lucien; Charles Théodore; Louise, who married Amédée Fortier; Gustave Valérien, married to Louise Marie Sarpy; Meloncy Charles, married to Louise Anne Exilée Fortier-named for the sad period in which she was born, after the Civil War, when Louisiana seemed indeed an exile from her once proud state.

This brings the line to the present generation, and notably to Mr. Charles T. Soniat, to whom we are indebted for the finding and publishing of the historic memoir of his great-grandfather. He was born on the plantation home of his father-the Tchoupi- 
toulas plantation in Jefferson Parish, obtained from Bernard Marigny in 1805. Barely thirteen years of age when the Civil War broke out he, like all the spirited youths in Louisiana, was fired with the passion of arms. To thwart his determination to join the Southern army, in which his brother Lucien had already enlisted, his father, on the fall of New Orleans to the Federal forces, sent him to France. Until the end of the war, he remained with his uncle Valmont Soniat du Fossat in Paris, where he completed his education.

On his return to New Orleans, he studied law in the office of his relative, Edmond Bermudez, afterwards Chief Justice of the Supreme Court of Louisiana. Upon graduation, finding the practice of law did not agree with his tastes, he obtained the commission of Notary Public. To the duties of this office he devoted the energies of his life with so much success that the title of "Perfect Notary" was given him. The good old name that he bore, the prestige of family and race, his courtesy of bearing and polished manners, constituted him in the eyes of society the perfect type of a New Orleans gentleman, as it is perhaps fatuously called; and he became to the beaux and belles of his day the perfect man of the world, as he became to the Bar the perfect notary.

But it is not by such qualifications that the great grandson of the first historian of Louisiana is to be remembered. Far otherwise. He became, for useful services to his State and people, as the prophet says, "a nail in a sure place." Always a student of Louisiana history, he became an active and zealous member of the Louisiana Historical Society, con- 
tributing to its publications papers written with scholarly preparation upon subjects that he gathered from a rich field all his own - that of notarial records.

In 1908, he published a transcript of a volume of original documents concerning the history of Louisiana, 1679-1769-the manuscript ${ }^{*}$ being reproduced with all possible fidelity, a storehouse of reference whose value is obvious and above praise. He also donated to the Louisiana Historical Society $\dagger$ the chronological statement of papers and documents concerning the history of Louisiana, obtained by him from the National Historical Archives of Madrid, accompanied by a letter from Don Miguel Gomez del Campillo, who had prepared the statement.

"His Titles to the Jesuit plantation" is in truth, a priceless document of historical and legal authority upon an intricate question-that of the land grants of the French Government to the first settlers around New Orleans. As it need hardly be repeated, Bienville and his followers (not inaptly called "Land Grabbers") obtained from their government, well in advance of the foundation of New Orleans, concessions covering all the land in the vicinity of the site already selected for the future city. Both banks of the Mississippi were sliced into plantations, so to speak, from the river back to the Gulf. These plantations, in course of time, were sold or divided by inheritance or marriage settlements, and afterwards reunited by purchase.

* Vol. I. Publications of the Louisiana Historical Society. He makes acknowledgment to Mr. William Beer, Librarian of the Howard Memorial Library for valuable assistance.

† Vol. IV. Publications of the Louisiana Historical Society. 
The Jesuits acquired the Bienville concession, the most valuable of all the concessions lying above the city. Their expulsion and the confiscation of their property threw the land back into the hands of speculators. Soniat's researches into the title of the Jesuits led him into the densest thickest of genealogical records and chains of titles. He reconstructed the first plans of concessions on the banks of the river and, link by link, connected them with the corresponding chains of family transactions. He transcribed it all with notarial neatness, precision and accuracy in a great ledger, with a mass of additional information, gathered together from personal observation, family traditions and newspaper articles. In short, he furnished so full and complete a store of historical gatherings that a student, in the vast ease and comfort it affords to research work, is tempted to exclaim: "Were all other land and family records of New Orleans destroyed, the data connecting family and property together could be recovered from this ledger alone!"

The immense work, a labor of love, was carried through privately; and at his death was modestly left, with his notarial business and office, to his brother Meloncy, also a notary, who holds it in trust and administers it for the benefit of the history of New Orleans and its students.

Charles Soniat died in 1918 in his home, situated between the two streets of his name, Soniat and Dufossat, and was laid to rest with his fathers in the old tomb whose preparation he had personally superintended and made ready for himself. The courtly old name still lives in New Orleans, though divested for the sake of simplicity of its aristocratic trappings, 
and become only Soniat. So, in truth, are its bearers in simple worth fulfilling their duties, in their several stations among the rank and file of good citizens.

It was with no surprise, rather with an expression of fulfilled expectation, that in his native city, the following item in a local newspaper was read in the closing year of the World War:

"Charles T. Soniat was one of the eight thousand United States marines who distinguished themselves at Château-Thicrry and fought at Belleau Wood. In command of one of the famous columns that marched through the retreating Poilus, behind Chatteau-Thierry, Soniat was directed to hold the Boches as long as possible and then retreat. 'Retreat, ——' he exclaimed. Instead his column advanced through Belleau Wood and beyond. The regiment was sent to Soissons; he fought one day in its victorious finale, when he was wounded, and was barely out of the hospital when the armistice came, and he sailed for America.

"The French Government gave him the Croix de Guerre, and he was promoted by his own Government. His name is one of four stars (Charles, Lucien, Leon, Guy) on the service flag in the home of his mother, Louise Marie Sarpy, widow of Gustave Soniat."

Leon died in the Aisne region while serving with the signal corps. His body lies in the fatherland of his ancestors, and it may be said about him, as about many a Louisiana boy who gave his life freely to France: "Here he lies where he longed to be." 


\section{CHAPTER XIV}

\section{DE IAA VERGNE}

THE present head of the family in New Orleans, 1 Colonel Hugues Jules de la Vergne, a student of Louisiana history and an authority on its colonial families, traces his line back to the twelfth centuryto Hughes and Renaud de la Vergne, Lords of St. Cupery and la Mauriange.* The Château de la Vergne at St. Priest, Ligourne, some twenty miles from Limoges, is still in the family, its actual possessor being the Marquis de la Vergne. The record in Louisiana begins with a Lieutenant Lavergne on the list of officers under Bienville in the Archives de la Marine, to whose name is affixed the note, "Has been only a year in the colony; has seen service. Sensible and very energetic."

Further along in history, in 1766, a Captain Lavergne signs the protest of officers and citizens against Rochemore, defending Kerlerec from the unjust charges made by the Intendant against him. Françoise de la Vergne, who married the eldest son of the Chevalier d'Arensbourg, belongs, according to our authority, to another branch of the family.

To follow the present line and the documents in the family: Pierre de la Vergne, Count and Chevalier of the Legion of Honor, a native of Brive la Gaillard, Province of Limousin, France, married in New

* Taken from personal notes furnished the author by Colonel Hugues Jules de la Vergne, New Orleans. 
Orleans, 1789, Marie Elizabeth (or Isabelle) du Vergier Marie, widow of Joseph Fides, Lieutenant and ex-Commander "del Esquadron de Caballeria de Mexico." She was the daughter of Guillaume du Vergier Marié and Rose Busson de la Marinière of New Orleans.

But one son was born of this union; Hughes (1789), who married, in 1813, Marie Adèle de Villeré, the daughter of the first Creole Governor of Louisiana and granddaughter of the illustrious patriot who was killed by the Spaniards. He had the honor of serving on the staff of General Andrew Jackson and of fighting in the Battle of New Orleans. He served also on the staff of Governor Robertson, the successor of Governor Villeré.

Although a member of the Bar and a Notary Public, he consented to fill the place of President of the Bank of "The Consolidated Association of the Planters of Louisiana," one of the numerous institutions organized when wealth, like a mythological stream, was flowing through the State, when money, accumulating like the rising currents of the Mississippi, threatened a golden overflow in New Orleans. Instead of which, however, the usual result followed a sudden fall after a sudden rise in values with the collapse of levees and crevasses of banks. Fourteen of the new institutions suspended payment. The Consolidated Association of Planters, notwithstanding its bulwark of a name, went down with the rest, but more tragically. Its President, proud, haughty, and a fanatic on the subject of personal honor, could not brook what he considered, foolish as it sounds to-day, an imputation upon it. Winding up the affairs of his bank, he crossed the river and made his 
way to the du Vergier plantation, where he sought the family cemetery. He was found on his mother's grave, pierced through the heart with a sword.

His only son, Jules, born in 1818, became a lawyer, and served also as Colonel on the staff of Governor Moore, and afterwards of Governor Allen, during the Civil War. He married Marie Emma Josephine Bermudez, the daughter of Judge Joaquin Bermudez and the widow of Meloncy Soniat. The only child of her second marriage is the present bearer of the name and title: Colonel Hugues Jules de la Vergne, a lawyer like his father and grandfather and an officer on the staff of the Governor of Louisiana. He was born in 1867. His biography, therefore, while not yet history, rests upon the pleasant foundation of social reminiscence and estimation. It may, however, be permitted to state that he is a helpful member of the Louisiana Historical Society-a student of historical records and a writer of note. He married Marie Louise Schmidt, daughter of the eminent jurist, the late Charles Edouard Schmidt. 


\section{CHAPTER XV}

\section{DE BORÉ}

GTIENNE DE BORE'S family, as we learn from notes left by his grandson, Charles Gayarré, belonged to the old Norman nobility. It ascends to Michel de Boré who, under Louis XIII, was a "conseiller de roi" and Director of Posts and Couriers between Paris and Orléans. Robert de Boré, his son, was also a Councillor in 1652 and was attached to the royal household.

Robert Louis de Boré filled the same offices as his father. He married, in 1654, Elizabeth Hotman. Their grandson, the first of the name in Louisiana, married in Kaskaskia, Illinois, Celeste Thérèse Carrière of that place. Their son, Jean Etienne de Boré, our de Boré, as New Orleans takes pride in calling him, was born in Kaskaskia in 1740. He was educated in France and, as soon as age permitted, entered the Mousquétaires du Roi or "Mousquetaires Noirs," the household troops of the King, a corps that none but a noble could enter: its privates holding the rank of captains, and captains the rank of lieutenant-generals in the regular army.

After ten years of service at court, de Boré was transferred to the command of a company of cavalry, but having married Marguerite Marie, daughter of des Trehans des Tours, a representative of an old French family who for many years had been Royal Treasurer in Louisiana, he resigned his position in 
the army in 1772 and came to Louisiana, where his wife possessed much property.

It may be remembered that des Trehans was sent back to France by Kerlerec as "too rich and dangerous;" in reality, because the Treasurer was a friend of Rochemore the Intendant, an unscrupulous enemy of Kerlerec and the leader of a cabal against him.

D'Estrehan had two other daughters: one married Pierre Philippe de Mandeville de Marigny; the other Favre d'Aunoy; his son married a Maxent, the beautiful lady who subsequently became the wife of Bernardo de Galvez. Besides her beauty there is but one fact remembered about her; that the daughter born to her and Galvez was named Guadaloupe and that the city for which she was named stood godmother to her and gave her a magnificent present in solid silver-one worthy of so wealthy a sponsor and the bearer of her name. But Guadaloupe died in infancy and never enjoyed her godmother's wealth or her distinction.

We must not omit to mention a souvenir of him that Gayarré always recalled with peculiar pleasure. De Boré had previously visited Louisiana on a leave granted by the Count Rochechouart Montboissier, the Minister of War, upon which occasion he had brought back from America some feathers which he presented to the Countess de Montboissier, the wife of the Minister. When he was ready to embark for Louisiana the second time, he received the following note from the Countess addressed to him as "Mousquétaire Noir à la Rochelle, Hotel du Bien Nourri. (Happy name for a hotel!) The old paper is worn and falling into pieces and the ink is 


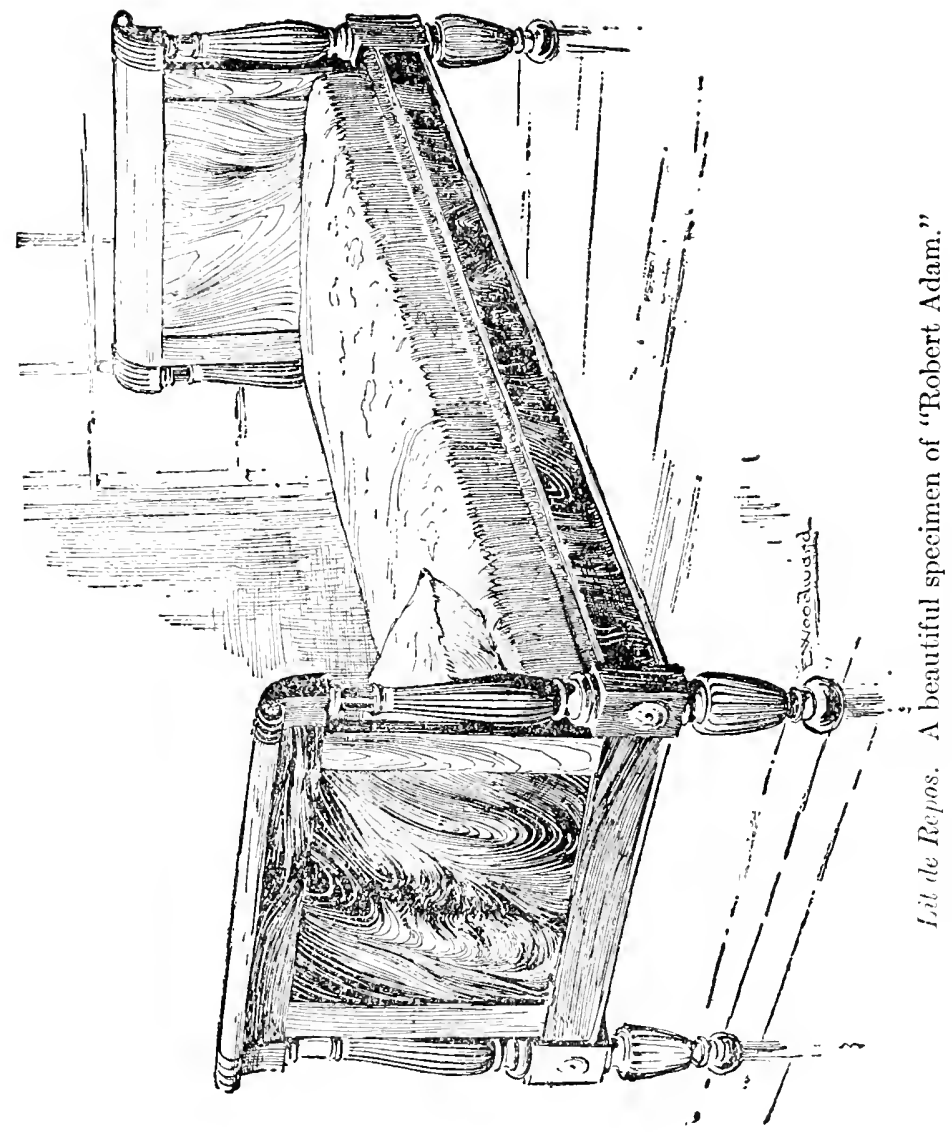



faded, but the pleasant words stand out upon it still clear and distinct:

PARIS, 9th January, 1772.

"It is with great pleasure, Sir, that $I$ have undertaken to inform you that the commission of Captain which you seemed so much to desire has been granted you 'par le dernier travail de M. de Montboissier.' When the brevet is ready he will forward it to you. He is very glad to have been able to render you this service. We both wish you a happy voyage and a speedy return to us after having arranged your affairs in that country sufficiently to your satisfaction. If it should be possible for you to send me a hundred feathers like those with which you had the kindness to favor me, my obligation to you would be very great. The trimming of my dress is finished; it is superb; and as I am afraid of losing some of the feathers, I should be happy to be able to replace them. I beg to be excused for thus taxing too much your gallantry and generosity, for you have given me such a large quantity of the feathers that it looked as if I would need no more. I return to you my thanks in advance, and $I$ entreat you to be convinced of the very great sincerity of the sentiments with which I have the honor to be, Sir.

"Your very humble and very obedient servant, "Rovchechouatt de Montboissier.

"P.S.-M. de Montboissier requests me to address to you a thousand compliments on his behalf."

The colony having by the time that de Bore arrived in New Orleans become quieted in the rule of the Spanish Government, he bought the plantation of the patriot Masan, who had been exiled and sentenced to imprisonment for life in Morro Castle. It was situated about six miles above New Orleans, measuring from the Cathedral, and was on the same bank of the river. The plantation above him was owned by Pierre Foucher, who became his son-inlaw; a portion of it is now Audubon Park. The plantation above Foucher's had belonged to Lafrénière, the great Louisiana patriot. His daughter, 
the widow of Noyan de Bienville, who was executed at the same time as her father, married Le Breton who, like de Boré, had been a Mousquétaire in the household troops of the King of France. He thus became the proprietor of the lafrénière place and his son eventually married a daughter of de Bore."

On Le Breton's death, he was assassinated by a petted slave (to follow the Gayarré's narrative), the plantation passed into the hands of Macarty and Lafrénière's great-grandsons, Des Chappelles Le Breton and his brother, Jean Baptiste Le Breton, who lived with their grandfather de Boré, serving on the managerial staff of the plantation. The other two managers of the plantation had also their historical significance. One was the nephew of General Klein d'Alberg, of Napoleon's army, afterwards a peer of France. Gayarré used to meet his son in Paris many years afterwards in the salon of the Baronne de Pontalba. The other employee, very small in stature, "almost feminine in manner and appearance; the most modest, the most tender-hearted of men," was the son of General Duphot of the French Embassy, who, under the First Republic, was assassinated in a riot in Rome by the partisans of the Pope.

The ex-mousquétaire gave his plantation a military appearance and ruled it with military discipline. His staff made their report to him every night and received their orders for the next day's work. Every morning at dawn a great bell assembled the whole force of laborers in front of the master's house, where they knelt and said a prayer before being detailed

* "A Louisiana Plantation of the Old Régime."-Harper's Magazine, March, 1887. 
to work-a member of the family always presiding during the prayer with head uncovered.

"I vividly remember," writes the historian Gayarré, seventy years afterward, "how I felt when, about eight years old, I was called upon for the first time to preside over the prayer of this dark assemblage."

When the day's work was over, the same ceremony dismissed the negroes to their rest. Before retiring at night and on meeting in the morning, the members of the family respectfully saluted Monsieur de Boré. "For a kiss on my forehead I returned one on his hand as if he were a monarch, and the same feeling of reverence was shown by all who approached him," writes the same historian.

From his service at court, de Boré derived the authority to cite in manners, customs and pronunciation, "la cour de Versailles"-the standard that reigned tyrannously supreme on his plantation. One of the anecdotes that Gayarré loved to quote (which is quoted here merely to preserve a personal memory) was that when a very small child, riding a stick-horse on the gallery of his home, he dropped or lost his whip and so began to cry out, " $J$ 'ai perdu mon fouet," pronouncing it "foi." Some young ladies and gentlemen sitting on the gallery gaily took up his cry to tease him, adding, "he called fouet, foi." M. de Boré, hearing the teasing, came out upon the gallery to defend his little favorite and, turning to the gay group, said: "Sachez, Mesdames et Messieurs, qu'à la cour de Versailles on dit foi et non fouet" (Know, ladies and gentlemen, that at the court of Versailles they say foi and not fouet."

De Boré's historical benefaction to Louisiana was that of establishing the making of sugar on a per- 
manent and sure basis in 1795 . Indigo had been the principal crop of the colony and all the plantations had been given over to its culture, but a worm that attacked the plant and destroyed it through several successive years was reducing to poverty and to the utmost despair the whole population. Etienne de Boré determined to make a bold experiment to save himself and his fellow citizens by turning his indigo into a sugar plantation. Hitherto, many attempts had been made to make sugar in Louisiana. As has been related the Jesuits had, in 1751, introduced the culture of sugar cane into Louisiana from their plantations in the Islands, and the planters who had followed their agricultural experiment had endeavored to make sugar from it. But, season after season, they had succeeded only in making syrup or, at best, a soft sugar that melted away in transportation.

De Boré resolved to remake the experiment to manufacture sugar in Louisiana and prepared to go into all the expense and incur all the obligations necessary for so costly an undertaking. His wife warned him that her father had in former years vainly made a similar attempt; she represented to her husband that he was hazarding on the cast of a die all that remained to them of their means of existence and that if he failed, as was probable, he would reduce his family to hopeless poverty. She reminded him that he was over fifty, of an age when fate was not to be tempted by doubtful speculations, as he could not reasonably entertain the hope of a sufficiently long life to rebuild his fortune were it

Note. “A Louisiana Sugar Plantation under the Old Régime,' Charles Gayarré.-Harper's Magazine, March, 1887. 
once completely shattered; and that he would not only expose himself to ruin but also to a risk much more to be dreaded - that of falling into the grasp of creditors.

Friends and relatives joined their remonstrances to his wife's, but could not shake the strong resolve of his energetic mind. He had fully matured his plans and was determined to sink or swim with it. Purchasing a quantity of cane for seed from two Spaniards, named Mendez and Solis, who cultivated it only for sale as a dainty or for the making of syrup, he began to plant in 1794. His venture excited the keenest interest and many visited him during the year to witness his preparations.

Gloomy predictions had been set afloat about him and on the day when the grinding of the cane was to begin a large number of friends and other citizens gathered about the sugar-house to be present at the failure or success of the experiment. Would the syrup granulate? Would it be converted into sugar? The crowd awaited with eager impatience the moment when the sugar boiler would be able to answer the question. The moment came; the stillness of death spread over them; each one was holding his breath feeling that ruin or prosperity was upon all. Suddenly the sugar boiler cried out triumphantly: "It granulates!"

Inside and outside the building one could hear the wonderful tidings flying from mouth to mouth and dying in the distance. Each one of the bystanders pressed forward to make sure of the fact on the evidence of his own eyes and, when it could no longer be doubted, there came a shout of joy and all flocked around de Boré, overwhelming him with congratula- 
tions and embracing the man whom they called their saviour - the saviour of Louisiana!

In a private gossipy letter to Thomas Jefferson, written in 1806, Governor Claiborne gives the following additional account of this episode which he heard from Colonel Macarty during a visit to his plantation:

"The Colonel esteemed the cane the only sure and lucrative crop which could be cultivated in the lower part of this territory. Formerly, indigo was the staple commodity, but for several years in succession the crops were diminished and on many farms entirely destroyed. The planters changed their seed and procured a species from Campeachy; for the first year this quality of indigo prospered, but was ultimately attacked by the common enemy. This destroyer was a worm called by the inhabitants 'vers luisants,' a species of the "ehenille," which commenced its ravages in the year 1790 . The prospects of the farmer were often blighted in a niglit. . . . Thus it was that indigo was finally abandoned and that the planters resorted to a more certain culture. Some raised corn, others cotton; but M. de Boré in the year ninety-six, turned his attention to sugar. The cane had previously been brought from Havana and had ornamented the gardens of Louisianians; but M. de Boré has the credit of being the first to introduce it in his fields. He succeeded beyond his expectations and found for his sugars an immediate and lucrative market.

"Other planters followed the example of M. de Boré, and the cane will doubtless be very soon cultivated in every part of this territory where the climate permits. The facility with which sugar planters amass wealth is almost incredible. . . . It is not uncommon with 220 working hands to make from ten to fourteen thousand dollars; and there are several planters whose field negroes do not exceed forty who make more than twenty thousand dollars a year. . . . The sugar planters raise a sufficiency of corn for their own use; nor do those citizens who reside near New Orleans neglect their gardens. I think Colonel Macarty told me that his daily receipts from the markets were equal to nine dollars.

“. . . Yesterday I dined with M. Destrehan; he is esteemed the best sugar planter in the territory and is perhaps the wealthiest; his sugars bring him in near thirty thousand dollars per annum and 
his rents in the city, six thousand. But he is nevertheless an economist; everything around him has the air of simplicity; his table is good but by no means luxuriantly served. He is much attached to retirement; and the education of his children (ten in number) and the improvement of his estate constituteat present his primary cares.

"M. Destrehan (de Boré's brother-in-law) is certainly a man of sense, but has strong prejudices and although they may be founded in error it is not in the power of man to remove them. He continues in the opinion that Congress has not been just to the ceded territory; but is nevertheless an admirer of the American government."

In 1796 a stirring event occurred on the plantation. The French General, Collot, on his way to New Orleans from the Western states and territories, stopped to visit Etienne de Bore. As soon as this was known in the city, the Governor, Baron de Carondelet, who had received from Philadelphia a confidential communication informing him that General Collot was intrusted by the French Government with a secret mission against which the Spanish authorities were to be on their guard, sent up an armed boat by the river and fifty dragoons by land to arrest him. The General was put in the boat and taken down to New Orleans, where he was imprisoned in Fort St. Charles (on the spot where stood the United States Mint). On the next day he was called upon by the Spanish Governor, who offered him a house in town which he might occupy on parole, with a soldier at his door. The General accepted the proposition and left the fort in the Governor's carriage. Shortly afterwards, his maps and drawings having been taken away from him, he was put on board one of the King's galleys and transported to the Balize, where he was detained a prisoner in the house of the chief pilot, Juan Ron-

Note-Official letter book of W.C.Claiborne. Vol. III, page 61 . 
qillo, situated in the midst of a vast swamp from which there was no egress except by boat. $\mathrm{He}$ remained there for two months, when he was allowed to embark on board an American brig for Philadelphia.

Etienne de Boré was extremely indignant at the arbitrary arrest of his guest, and he expressed his feelings loudly and without restraint. As he was known for his intense attachment to France and her interests, it is said that the Baron thought seriously of having him also arrested and transported to Havana, but that he was deterred by the fear of the commotion that would be produced by inflicting so harsh a treatment on so distinguished a citizenone who by his personal character, his rank, his family connections and the benefit he had lately conferred on Louisiana by the introduction of a new and valuable branch of industry, commanded universal sympathy and exercised the widest influence.

What an imaginative child hears, he sees; and the historian in after days could relate this event as if his heart and not merely his memory had been tinged by it. In the same way, he could relate that truly royal moment in the hospitality of his old home when the three illustrious visitors, the Duc d'Orléans, the Comte de Beaujolais and the Duc de Montpensier passed some days there. As the old mousquétaire repeated to his grandson:

"Little did I think when in the household troops of Louis XV that the day would come when three princes of the blood would be my guests on the banks of the Mississippi."

When the colony was transferred from Spain to France, de Boré was appointed Mayor of the city of 
New Orleans for reasons that Laussat explains in his confidential despatch:

"I thought also of securing without loss of time an imposing support in the civil department of the government and I selected for Mayor of the city, M. Etienne de Boré, a native of Louisiana of a distinguished family, formerly mousquétaire in France, one of the largest and most skillful planters of the province; a gentleman renowned for his patriotism and for a character of undeviating independence. I made a powerful appeal to him in the name of his country whose interests required his services and I had the satisfaction to win him over. After M. de Boré, and through his influence, I secured the services of some of the most distinguished among the colonists."

De Boré continued to act as Mayor during the initial years of the American Domination and faithfully endeavored to bring into the management of the city the same order that reigned on his plantation. He ably seconded Governor Claiborne in his efforts to prevent an outbreak between the turbulent Americans and the excitable Creoles whenever they met-particularly in the exciting scenes that spoiled the pleasure of the public balls when the Americans would call out for their favorite dances, the Creoles for theirs; and such an uproar would ensue as to frighten the ladies and drive them away, while the gentlemen would try to enforce their desires by their swords or even fists. De Boré regulated this disorder by drawing up a programme with American and French dances, alternating in regular succession; and stationing gendarmes to enforce it.

Bernard Marigny describes such a scene in a ball given in 1804 in the "Salle rue Condé." The AngloSaxons, who loved to amuse themselves, but in a different manner from the people of French origin, 
asserted that as Louisiana had been bought by the United States the amusements should be conducted according to the American taste, that the "rill" (reel) should replace the waltz, and the jig the cotillion. The Creoles, informed of these ridiculous pretensions, attended the ball, as well as the French, who were naturalized Americans, by the fact of the cession of Louisiana to the United States. An infernal row took place; the men were armed. That evening was to decide whether the reel or the waltz was to triumph. In the midst of so much noise and confusion which frightened the beau sexe, who were all on the point of retiring from the room, a young lady jumped on a chair. She belonged to a family in which wit was and is a heredity. Her face was animated by excitement.

"Sirs," she said to the furious Americans, "for thirty years we were Spaniards, and the Spaniards never forced us to dance the fandango. We wish to dance neither the reel nor the jig."

The astonished Americans asked all over the room, "What did she say?" General Wilkinson, who was present and exerting himself to induce calm, stood on a chair and translated what the beautiful Creole had said and ordered the musicians to play a waltz and to the great astonishment of every one began to waltz himself. Crying "Hurrah! Hurrah!" The Anglo-Saxons, vanquished by Beauty, began also to dance.

Claiborne, in a letter of May 21st, 1804 acknow-

Note.-From "Reflexions sur la campagne du General Jackson en Louisiane en 1814 et 1815," by Bernard Marigny. New Orleans, 1848. 
ledges receipt of a letter from de Boré announcing his wish to resign the mayoralty.

"I cannot," writes the Governor, "but regret the circumstances which have induced your relinquishment of an office the duties of which have been discharged with so much credit to yourself and advantage to the city."

When the territorial government which had been decreed by Act of Congress went into operation in Louisiana, de Boré was appointed a member of the Legislative Council by the President. He had, however, been one of the leaders of the opposition against the establishment of a territorial government, when full statehood in the Union had been stipulated in the cession by Napoleon; and as he had been most zealous in stimulating his fellow citizens to remonstrate against the form of government imposed upon them, he could not aid in establishing it and, therefore, declined the proffered seat in the Legislative Council. This refusal, with that of the other gentleman named by the President, had a considerable influence on other members, who held back in dubious suspense; and two months nearly elapsed before a Council could be formed, notwithstanding the incessant efforts of Claiborne to soothe and conciliate the refractory tempers that he had to deal with.

The portrait of the ex-mousquetaire and planter bears out the character given by his grandson. It represents a man of sixty of quiet dignity and simple manners, looking at one with piercing, shrewd, yet kindly eyes, and with a pleasant paternal smilein short, a man of business ability and a good disciplinarian, though of benevolent disposition. 
His house was furnished in the style of plain simplicity that prevailed among the planters of his day, but the table and wines went to the other extreme. In the memory of Gayarré, they were, as he wrote, "superb," and the hospitality they graced were worthy of them. Every Sunday there came regularly to dinner a score or two of guests from New Orleans. Among them some Knights of St. Louis, wearing their decorations, struck the imagination of the future historian; among them the Hazures, two brothers who lived near the Bayou St. Jean on the Gentilly Road. (Their tombs may be seen to-day in the old St. Louis Cemetery.)

"There was something," says Gayarré, "in all those waifs of another age, in their appearance, in their dress, in their physiognomy, in their manners, in their peculiarities of conversation and language, in their bows and greetings, in their accent and the modulation of the voice, that produced a most vivid impression. These men of the old régime scemed to entertain more esteem and respect for each other than we do now for our contemporaries. As I grew in years I became more deeply impressed with the faith which men of that epoch reposed in one another."

And again:

"There is not a vestige, not a wreck's fragment of the de Boré plantation left," writes Gayarré at eighty with pathos, "save myself, standing alone, forgotten but trying in vain to forget."

M. de Boré died when seventy-eight years of age; at his very last moments he summoned his grandson to his presence. Putting his hands on his head, he blessed him and gave him his parting instructions and recommendations with a firm voice:

"Let no temptation ever betray you out of the path of honor and virtue. Keep your conscience always free from self-reproach, so that your death may be as calm as mine. Trusting in the mercy of 
God, I fear not to appear before His tribunal where I hope not to grieve for you when in due time we are to meet again and when you shall render your accounts to Him."

According to his directions his funeral and his tomb were to be of the plainest kind, and the thousand dollars that might have been spent upon them given to the Charity Hospital.

He died February 2nd, 1829. On a little side path of the old St. Louis Cemetery may be seen his last resting place. The tomb, as he requested, is of the plainest kind, with no inscription upon it but his name and dates. In the great hall of the Charity Hospital, a tablet bears the record of the donation of a thousand dollars given by his family. 


\section{CHAPTER XVI}

\section{GAYARRE}

Non l'avenir n'est a personne

Sire! l'avenir est a Dieu!

Qui sait si l'onde qui tressaille,

Si le cri des gouffres amers,

Si la trombe aux ardentes serres

Si les éclairs et les tonnerres,

Seigneur! ne sont pas necessaires

A la perle que font les mers!

- Victor Hugo.

GAYARRE is the first fruit of the grafting of the stock of Spain upon the French stock growing in Louisiana. The grafting came about in this wise. On March 5th, 1766, as the standard bearer of the name himself relates, the long expected and much dreaded Ulloa arrived in New Orleans to take possession of the colony of Louisiana for Spain. He landed with two companies of infantry and was accompanied by three joint commissioners: Loyola, Commissary of War; Gayarré, Contador or Comptroller; and Navarro, Treasurer.

While it is conceded by all historians that Ulloa was totally lacking in the qualities needed for the proper performance of his high office, it is as generally recognized that no better men than the three commissioners could have been named for the duties entrusted to them-duties which even the irate Creoles handsomely avowed they accomplished, not only as loyal servants of the King, but also as Spanish 
gentlemen of the highest rank. They, therefore, were never included in the rigid ostracism practised against Ulloa, but on the contrary, from the first were received with the respect due them and accorded the generous hospitality of the citizens.

Don Juan Joseph de Loyola belonged to the famous family of Guiposcoa, which produced the great founder of the Jesuits; and he showed the elegance of manner, the high breeding and the knightly courage that distinguished his celebrated kinsman, Ignatius, in addition to his poetical mind, luxuriant imagination and religious enthusiasm. Don Martin Navarro, on the contrary, was the son of a poor tavern keeper who had risen by dint of industry, perseverance and address. Shrewd, active and honest, he deserved the confidence he gained, and being, withal, a boon companion and skillful in the ways of the world, he had also the genial qualities that make smooth and easy the path to social success.

Don Estevan Gayarré, the great-grandfather of Louisiana's historian, was the younger son of a patrician house of the Kingdom of Navarre. He had enlisted at the age of nineteen in the army of Spain and he served in it with distinction for twentyfour years. His health being impaired from a wound received in the war with Italy, he was in 1755 permitted to retire, and was a year later appointed Contador for the army and the Kingdom of Gallicia. He was finally chosen for the place of Contador in the newly acquired Province of Louisiana.

$\mathrm{He}$ is pictured by his great-grandson as a man excelling in all the gentle qualities of an affectionate nature, besides possessing a mind far above the ordinary. He showed, especially, the robust traits 
of character that distinguished the hardy race of mountaineers among whom he was raised in the valley of Roncal, in Navarre, surrounded by the impressive scenery of the Pyrenees. His young son, Juan Antonio, joined him in New Orleans.

The three courtly Spaniards, during the uneasy month that followed Ulloa's arrival, when Lafrénière's fiery eloquence was kindling sedition in the populace, increased their circle of friends and found more and more doors opened to them, although they were in constant attendance upon their obnoxious commander.

The tradition that accounts for the pleasant social bridging of the ugly chasm of hatred contains two pretty versions. According to one, the Spanish gentlemen themselves were too refined and polished not to appreciate the charm of the place and of the society into which they had been thrust so rudely, so that they showed their feelings of admiration and sympathy for the ladies and gentlemen whom they met. The other version states that the ladies and gentlemen of New Orleans' society who met the Spanish officials were themselves too sensitive to high-born manners and the charm of graceful courtesy to resist their own hospitable desires and make known the pleasures of their table and salon to the strangers. Thus was brought about, despite political opposition, the conditions necessary for the sowing of Spanish seed in French soil. It is on record, however, that although subjected to many attempts to elicit information from them as to the feelings and plans of their commander, the Spanish gentlemen could always manage to answer in a manner that silenced or parried inquiry without loss of cordiality. 
The enigmatic Ulloa, after an absence of seven months at the Balize, returned in March, bringing with him in triumph his beautiful young bride, the Marquise d'Abrado, celebrated as one of the richest women of Peru. They opened their house and gave receptions on three evenings of the week. The Spanish officers attended as a matter of course; also the three commissioners and a sprinkling of French officers, with the citizens who had been put on the Council instituted by Ulloa to supply the place of the discarded French Superior Council: de Grand Pré, de Grand Maison, Ollivier de Vezin, de la Chaise (the brother-in-law of Villere and kinsman of Lafrénière), Reggio, Maxent and Dreux. But none of the ladies of the city, as they always proudly recalled, could bring themselves to pay Madame Ulloa the civility she expected from them, and the beautiful stranger and her Peruvian girls, sneered at as "colored," reigned alone in her dismal soirées. In fact she was more hated, if that were possible, than her husband.

On the first appearance of danger, Gayarre, Loyola, Navarro and the few other Spaniards who were in the city, with some of their French friends, gathered around Ulloa to die with him or save him. They barricaded his house and put it in a state to stand a siege. From time to time the frenzied people would come rushing upon it, uttering fierce shouts and cries of vengeance, but they were always restrained at the last moment and prevented from committing the outrage intended. In the evening, when Ulloa sullenly consented to retreat to the Spanish frigate awaiting him, the three Spanish commissioners accompanied him. A large concourse of 
people waited on the river bank to see his departure. As Loyola, Gayarré and Navarro approached the bank, returning from the Spanish vessel in their boat, the crowd opened before them with respect, and as the gentlemen passed through to their residences they bowed right and left with stately formality; in their steady look there was neither fear, anger nor defiance, only an expression of cold indifference. And it is always related as typical of the manners of the Spaniards that, as the vessel glided away, the Captain, standing on his quarterdeck, bowed to the crowd while the guns of his ship fired a salute.

In the calm that followed the storm, the revolution being accomplished, an ominous stillness fell upon the minds of the populace and all ideas of further resistance were gradually abandoned. The schemes of the idealistic Lafrénière and his partisans began to demonstrate their utter impracticability. Loyola, Gayarré and Navarro saw their circle of friends increasing and their importance in the colony rising. They were men capable of sympathizing with the growing anxiety of their friends and the cruel torture of their suspense. They became painfully affected, says Gayarré, by the direct and indirect appeals to their feelings; but not knowing what course their government would pursue they had to be careful not to commit themselves in any official way, confining themselves to assurances only of their feelings and wishes and to what they thought might be expected from the well-known clemency of Carlos III.

Thus matters stood, to continue the narration of Gayarré, when, on the 24th of July, 1769, New 
Orleans was thrown in a violent cornmotion by the news that a formidable Spanish fleet had made its appearance at the Balize in command of General O'Reilly who had been appointed to take possession of Louisiana and who had brought with him such a large army that resistance would be impossible. The leaders of the insurrection, seeing at last the hopelessness of their condition, became greatly alarmed and, in desperation, sought counsel from Aubry. He cheered and encouraged them with his belief that O'Reilly could not possibly have the intention of spreading terror and desolation in the province, and he counselled them to see the General themselves. As no blood had been spilled, it was to be hoped that if the colonists submitted now promptly, their trust in the clemency of His Catholic Majesty would not be in vain.

In the afternoon came the news that a Spanish officer was coming up the river with despatches from O'Reilly to Aubry. "On that night," to profit by Gayarré's description, "there was no thought of sleep for the greater part of the population. They were seen clustering in groups in the streets or hurrying from house to house. About ten o'clock, Loyola, Gayarré and Navarro, preceded by torches and followed by friends, were seen going through the streets to the landing place. At eleven, the Spanish envoy, Francisco Bouligny, arrived in front of the Place d'Armes, and, jumping ashore, was greeted by his countrymen. Passing through the large and anxious crowd, they quickly walked to the house of the Governor, who was in bed, but he arose at once to receive O'Reilly's messenger, who translated to him the Spanish communication that 
he bore. On the next day Bouligny, the three Spanish commissioners and the most influential among the French officers and citizens dined with Aubry. The dinner was very gay, and Aubry took occasion to assure Bouligny that the people had listened to counsels of prudence and were prepared to act on them.

When Bouligny departed the following day, he was accompanied by Lafrénière, Marquis and Milhet who had decided, according to their wellknown courage, to present themselves to the Spanish General and assume the responsibility of the revolution. After forty hours on the way, they reached the Balize and were presented by Bouligny to O'Reilly, who received them with dignified politeness. After a long interview with them he detained them to dinner, treating them with the most delicate attention, displaying the utmost suavity of manner and, in short, sending the Creoles away fully impressed with the certainty that their past misdemeanor should be forgotten, reports Bouligny who was present at both interview and dinner.

The city sighed with relief and hope began to soothe its troubled inhabitants. We know the subsequent movement of the drama and its tragic fifth act. Shakespeare himself could not have invented a more poignant crisis than the arrest, the trial, the condemnation, the appalling sentence and the agony of the citizens. Some of the Creole ladies whose husbands, fathers or brothers had taken no part in the revolution but who were, on the contrary, in favor of Spain, hoping to exercise some influence over O'Reilly, demeaned themselves, as 
they afterwards felt it, to make a passionate appeal to him for mercy for the condemned, pouring out their souls to him in supplication; but the IrishSpaniard, looking upon them with his cold, crafty eyes, resisted them with inexorable firmness and with the same "suavity" of manner that his friends say characterized him. Loyola, Navarro and Gayarré, under the irresistible impulse of their own feelings, went to him and spoke for the people among whom they had lived for three years, advising the hard-hearted man at least to assume the responsibility of suspending the sentence until further orders could be received from Spain. Their answer was that the condemned would be executed the next day-and they were.

When O'Reilly departed, Loyola went with him to Cuba, where his wife awaited him. Navarro followed soon after. Don Estevan Gayarré remained in Louisiana with his son who had been appointed by O'Reilly Commissary of War, although but eighteen years of age. Don Estevan subsequently obtained leave to retire to his native country and to be put on the list of retired pensioners. He died at the close of the century. The following letter written by him to one of his grandsons in Louisiana was preserved by Charles Gayarré, and was often quoted by him in his old age-with sad effect.

"My son, I may say that I have already one foot in the grave. I have little of earthly goods to bequeath or dispose of, contenting myself with leaving at my death what will be necessary to bury me in seven feet of ground with the little but honorable exhibition of military pomp, within which have shrunk all my vain hopes in this miserable world. Yea, such is this world! Its flitting glories fade away-and there remains nothing but the alternate lassitude and 
self-torment of thought. Therefore a pure and sound mind ought ever to have its eyes fixed on heaven."*

Don Juan Antonio Gayarré was one of the brilliant young Spanish officers who effected practically the union of Louisiana with Spain by marrying into the families of the French officials of the province. According to the precise notes left by him in his own beautiful handwriting, he was born "or baptized in the Catholic faith, for in Spain no difference is made between them," on the 14th of March, 1752. On April 23rd, to follow the venerable record of the Cathedral, "the Sieur Jean Antoine Gayarré, legitimate son of Sieur Etienne Gayarré and Dame Marie François Cochard, was married to Dame Constance Grand-Pré, native of this parish, and legitimate daughter of M. Louis de Grand-Pré and Dame Thérèse Galar de Chamilly," in the Cathedral of St. Louis." The record bears the interesting signature of Fr. Dagobert, grand vicar and curate of the parish.

The Chevalier de Grand-Pré had come into Louisiana in the time of Bienville and had received the Cross of St. Louis for his long and faithful service. It is of significant interest to note that this Chevalier de Grand-Pré was a descendant of the Sieur Pierre Boucher, the early Governor of Trois Riviéres in Canada, and the first Canadian ennbloed by Louis XIV. He was also the author of the first published account of that country.

Carlos Anastasio Estevan de Gayarré (the father of the historian) was born on January 2nd, 1774, and, "to conform to the custom of this country," was baptized on the 12th of February, 1775.

*From "The Spanish Domination." 
The godparents ware the grandparents, with Don Luis Nicola de la Landa and Donna Juana Sophia de la Landa. Antonio Estevan de Gayarré, the second son, was born in 1775. Luis Estevan de Gayarré was born in 1777 .

Don Juan Antonio Gayarré distinguished himself second only to his brilliant commander-in-chief, Galvez, in the glorious little campaign against the English in 1779, which resulted in the conquest of Manchac, Baton Rouge, Natchez, Mobile and Pensacola, or the whole English Province of West Florida. In the distribution of honors and rewards that followed the successful termination of the war, Don Juan Antonio Gayarré was appointed Contador Real of the rich post of Acapulco. He died there and his wife returned to her birthplace, bringing her three sons with her.

Of these, Carlos married the youngest daughter of Etienne de Boré. He lived with de Boré on his plantation and became the father of the historian. Although born in Louisiana, he remained fixedly loyal to Spain and to his Spanish ancestors. Always at the head of his bed, relates his son, hung his coat of arms with its three mountains spanned by a bridge, surmounted by the turbaned head of Abderahman, the testimonial of the proud day when the Gayarrés defeated the Sultan in their native valley of Roncal, about the year 800 . When Napoleon invaded Spain, Carlos Gayarré, in the presence of his father-in-law, respectfully suppressed his feelings. But when came the announcement of French triumphs in Spain he would retire to his chamber in which his little son would hear the sound of passionate playing of the 
guitar and the passionate singing of Spanish patriotic songs.

He held an office under the Commissary of War when the colony was transferred to France and was one of the Spanish officers who consented to receive a commission from the French Republic. The colonial prefect, Laussat, appointed him First Lieutenant of the Third Company of Louisiana Militia in 1803. In 1807, he was appointed Captain of the Fourth Company by Governor Claiborne. His name is enrolled in the first Masonic Lodge founded in Louisiana. To quote his own note, "On the 1st June, 1799, I was received as Mason in the 'Parfaite Union." ' One of the relics remaining of him is a little packet which contains his regalia and the certificate of the degrees that he took in the order. His portrait represents him in the prime of his youth and manly beauty; he did not live beyond them, dying in 1813, in New Orleans. He was buried in the tomb of his wife's family in the old St. Louis Cemetery.

Like his father, he left behind him a "note de ma naissance et celle de ma famille":

22nd January, 1774, I was born.

19th January, 1783, was born Dame Marie Elizabeth Bore, my wife.

9th January, 1805, was born Charles Etienne Arthur, my eldest son.

12th June, 1807, was born Ferdinand Etienne Gayarré, my second son.

*Ferdinand Gayarré had an unhappy life, and died in consequence of it in his early prime. 


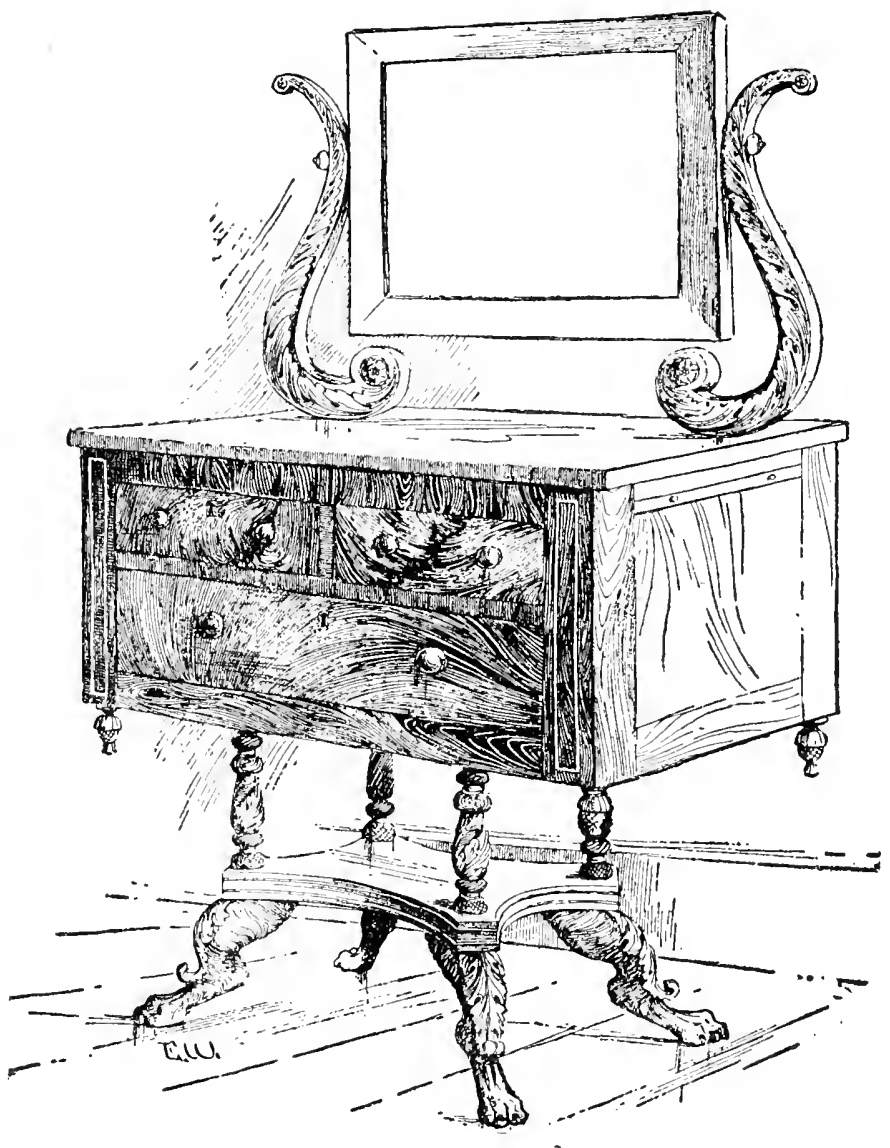

Toilette Table. St. Domingo Mahogany. 



\section{CHAPTER XVII}

\section{CHARLES GAYARRÉ}

CHARLES GAYARRE, the historian of Louisiana 1 -name and title came almost together ninetythree years ago, and so closely has the slow process of time welded them that it would take as many years again to divorce them or for our ears and tongues to unlearn their habit of coupling one with the other. To Louisianians, indeed, it seems that Gayarré was not only the historian of Louisiana but the history of it as well; and when, upon the morning of February 11th, 1895, it became known that Charles Gayarré had passed away, when the little black-bordered notices of his death were affixed to the posts on the street corners of New Orleans, according to the local custom, the feeling aroused was not simply that a great and a good and a useful life had ceased to exist in the community, but also that a great, good and useful volume had been closed - the volume of the past of city and statewhich had stood so long open and ready for all who wished to profit by it that, like old folios and precious classics in public libraries, it seemed chained to our eternal service.

Charles Gayarré was born in the month of January, 1805 , and baptized in the parish church of the Cathedral of New Orleans, receiving the name of Charles Etienne Arthur, or, as it stands in the 
Spanish, Carlos Estevan Arturo. The ceremony was performed, registered and signed by Fr. Antonio de Sedilla, the Père Antoine whose name is connected with the church of Louisiana in the same indissoluble manner as the name of the infant he baptized with its history.

The cession of Louisiana to the United States was still a recent event in the city. The official act and pageant of transfer had taken place only the winter before. Of the large group at the baptismal font, the infant was the only American; the others were all colonists-French or Spanish. Ninety years later, Charles Etienne Arthur Gayarré was again borne into the church of St. Louis to receive its last, as he had received its first, blessing on his life.

His life had been a long one, overspanning the average, not by years but by generations. He had seen the new things of his parents' day become old, and the old linger along in the heart like the echo of a cathedral chant; he had seen the transplanted flag, language and government become home bred to the soil, and the people who had stood around his baptismal font disappear in the dim distance of tradition. In his childless old age, when time was bearing him ever farther and farther from his native time, he used to sigh over his isolation and the dreariness of that land of exile in which octogenarians live. Of all the friends that he started with in youth, a goodly circle, but one, a schoolmate, survived to accompany him to the end.

Fr. Antonio's certificate of baptism, with other certificates antedating it, signed by him or his no less celebrated predecessor, Père Dagobert, recording the baptism, marriage, death, of father, mother, grandparents, uncles, granduncles, together with 
testaments, titles of property, and preciously guarded letters, remain in the archives of the Gayarré family. They must have been laid aside in some miraculous casket, it would seem, to have been preserved entire through the fierce tempest of war, ruin and devastation that scattered and made flotsam and jetsam of all that the lives that they chronicled held as tangible possessions.

Like poets, historians are born, not made. As a child, Gayarré lived in intimate touch with the chronicles of a century earlier than his own. By merely listening to his home gossip, the tales of maternal and paternal reminiscence, and the talk of nurse, teacher and playmate, he could see and feel in imagination not only the very beginning of the Colony, but the conception of its beginning, in Canada and in Normandy. What followed thenceforth-French and Spanish Domination, the cession to France, and the cession to the United States-he knew as the child born seventy-five years later, knew the events of the Civil War and of the reconstruction era. What historians of to-day study painfully from documents (now that Gayarré is no more), he knew as he knew his family ties. Our historical questions were to him questions of memory; and his memories have become to us historical documents.

Gayarré tells us in some of the most charming and valuable pages he ever wrote, "A Louisiana Plantation of the Old Régime,"* how he passed his childhood on the plantation of his grandfather, Etienne de Boré. It was situated six miles above the city, measuring from the Cathedral, and was reached by the public road winding along the river bank.

*Harper's Magazine. March, 1887. 
In front, it presented an imposing appearance. The avenue of pecan trees that led from the highroad was arrested by a deep moat, edged on its farther side by an impenetrable hedge of Yucca or "Spanish Bayonet." Behind this was a great grasscovered rampart bearing a massive brick wall. But Nature then, as now, proved a mocker of the imposing. The waters of the jealous moat became in time thick with dainty fish. The Yucca hedge, with its sharp-pointed dagger leaves, sent up such luxuriant staffs of its beautiful waxen, bell-shaped flowers that it made the spring glorious to the child, and the sturdy rampart and surrounding brick wall so protected an inner hedge of wild orange that its golden fruit made the winter as resplendent. The drive to the house described a circle, and was bordered with sweet orange trees, whose golden fruit made it glorious.

Gayarre tells us that he learned his alphabet from one Lefort, who lived in a house on the upper limit of the Foucher plantation and kept a school which was well attended by the children of the planters on both sides of the river. Lefort was a man of culture but rough and given to whipping his pupils unmercifully. When past eighty, the historian related that he had not yet forgotten the blows given him, when a child of six, for imperfect pronunciation of the English word "the." At nine years of age, Gayarré was promoted from this teacher and sent as a boarder to the College of Orleans. In the opening pages of "Fernando de Lemos," he describes this historic institution of learning, with its courtly President, Jules d'Avezac, whom the students affectionately nicknamed 
"Titus," and its corps of professors, composed of original types of scholars and gentlemen. The rules of life and study there were Spartan in their austere simplicity, and they were enforced with Spartan sternness. No puerilities, except in age, were permitted the scholars. Even the afternoon walks and weekly visits to the theatres were administered with rigid regard to duty rather than to amusement.

Gayarre was in this corlege in the memorabie year of the British invasion. He relates that, on the second of December, about three o'clock, there was a great commotion in the learned precincts. The news had arrived in New Orleans that the British had landed in Louisiana and that they had been seen on a plantation below the city. Studies were suspended, classrooms closed, alarmed pupils hurried to and fro, parents poured in to take their children away. Gayarré and his cousin, Frederic Foucher, were left so long that they began to fear they had been forgotten and had been left to shift for themselves in the face of the British invasion. At the last moment, however, an aunt sent for them. She lived in a house on Dumaine and Royal Streets, and the two boys stood on the gallery, with her and other ladies of the household, and looked at the troops marching by, hastening to meet the enemy below. At seven o'clock the fighting began, "and the roar of artillery and discharge of musketry were almost as distinctly heard as if the battle were in the immediate neighborhood. There was not the slightest noise in the city; it held its breath in awful suspense."

The two boys and the ladies, petrified into absolute 
silence by their apprehensions, stood on the balcony until half-past nine o'clock, when the firing gradually ceased; and then they passed a never-to-be-forgotten hour of anxiety. Were their defenders retreating, pressed by the enemy? What was happening? About eleven o'clock the city's awful silence was broken; the furious gallop of a horse was heard, and the cry of the horseman, shouting as loud as he could, "Victory! Victory!"

Early the next morning the children were sent to their homes. On the eighth of January, when the decisive battle on the field of Chalmette was fought, the child stood on the gallery of his grandfather's house, with the ladies of the family, who were pale and trembling with fear. No man was visible: the only one, de Bore, who had remained at home, on account of age, had, when the battle began, gone up to the top of the balcony for observation. When the firing ended he came down from his post and announced to his daughter that the Americans were victorious. His soldier's ear had distinguished that the American guns had silenced the English.

All that is known of Gayarre's youth is what can be gathered from his descriptions of other people. He stayed at the College of Orleans until he completed his education in 1825; when twenty years old, he published his first work-a pamphlet on the subject of the Livingston Criminal Code, opposing some of Livingston's views, and particularly his recommendation of the abolition of capital punishment, which the young Creole combated as an innovation of dangerous application in the State of Louisiana. The pamphlet, whether it aided public opinion on the subject or not, certainly reflected it; 


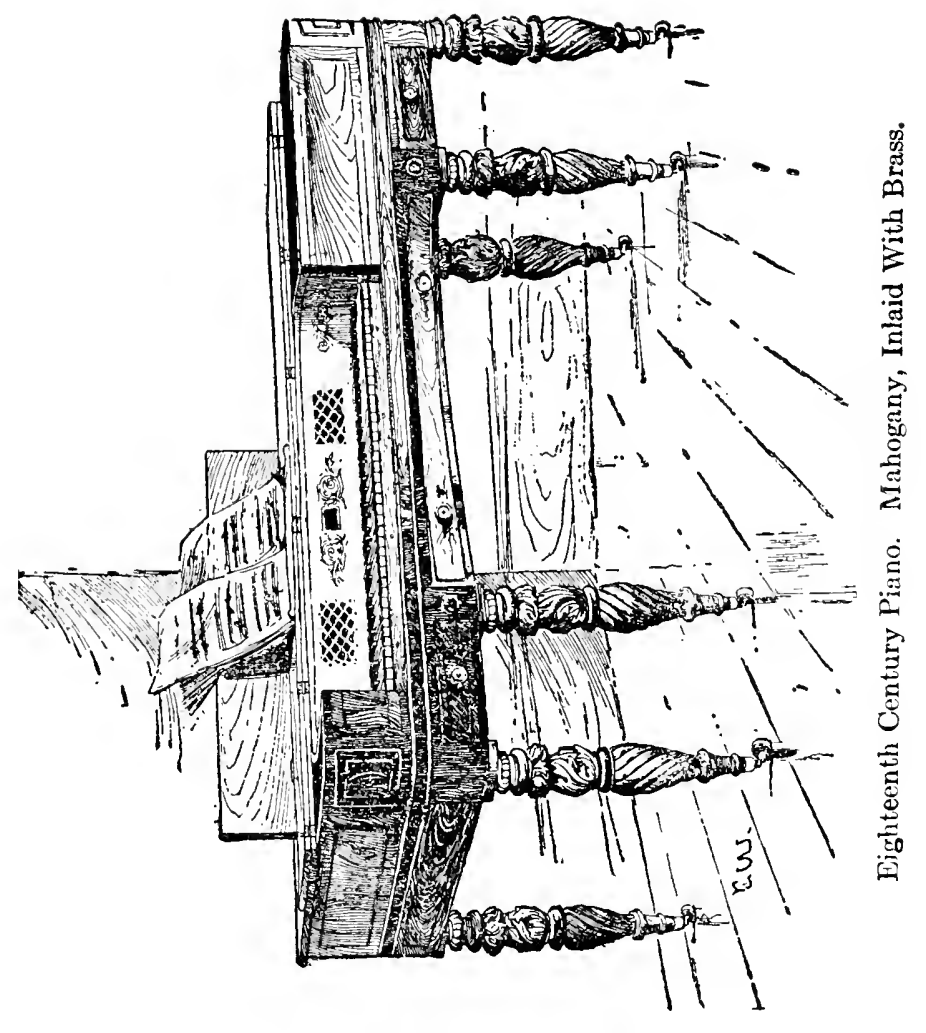



for Livingston's system of penal law for the State of Louisiana, though it was admired and commended by the most celebrated philosophers, philanthropists and statesmen of that day, was never adopted by the State for which it was framed.

In 1826, Gayarré went to Philadelphia and remained there for three years, for the double purpose of studying law and of perfecting himself in the English language, which was still taught and spoken as an alien tongue in New Orleans. He studied in the office of William Rawle, the distinguished jurist and legal author. He was admitted to the Pennsylvania Bar in 1828; a year later, upon his return to New Orleans, he was admitted to the practice of law in Louisiana.

The man of that era whose character to us of today was most strongly marked, whose individuality was most clearly cut against the background of the time, was François Xavier Martin, Associate Justice of the Supreme Court of Louisiana, and author of a then recently published "History of Louisiana." No one, to judge by the accounts that have come down to us, received so keen, so just and so true an impression of Martin's greatness of intellect as Gayarré, and no one so fully showed the effect of it. Martin was the determining force in Gayarré's life. He was, in effect, Gayarré's literary progenitor.

The two volumes so rare nowadays and so dear to Louisiana book lovers-Martin's first edition of 1827 and Gayarré's "Essai Historique sur la Louisiane," 1830-stand to one another in a nearer and more sentimental relationship than that of mere literary succession, as the product of each shows. In addressing himself, as an old man, to "Louisiana's 
youthful citizens," Martin not only enumerates the steps by which Louisiana advanced from Indian barbarism to state sovereignty in the Federal Union, but also traces for the young historian a plan of future work which Gayarré faithfully carried out in later years.

Gayarré's preface in his first essay at writing history is an ingenuous response to Martin's appeal. "A Louisianian by birth and blood," he describes himself, "who has read with emotions of filial piety the "History of Louisiana," " which Judge Martin has published in English. Gayarré acknowledges that he owes most of his material to the venerable magistrate and makes a timid apology for his feeble essay at an attempt to bring the history of Louisiana within reach of those whose tongue is French.

Upon his return from Philadelphia (before he published his "Essai Historique") he was elected, by a unanimous vote, a representative of the city of New Orleans in the Legislature. There he received the compliment of being chosen by the Legislature to write an address complimenting the French Chamber on the revolution of 1830 . In 1831, he was appointed Assistant Attorney-General. In 1832, he became presiding Judge of the City Court of New Orleans. In 1835, when he had barely reached the constitutional age, he was elected to the Senate of the United States.

The calamity of his life, as he always felt it, overtook him here. A distressing form of malady had fastened upon him, and it seriously impaired his capacity for work. He decided to go to France and seek medical assistance before assuming his duties at Washington. Three eminent physicians pronounc- 
ing his case too far advanced for relief, he resigned his seat in the Senate and remained in France for medical treatment until 1843.

Readers of Fernando de Lemos can follow him as, under the thin disguise of a pseudonym (a favorite literary device of the period), he travels hither and thither in France, now to some springs to drink the waters, now to some city or town in search of historical information, conversing on the road with his fellow travelers of all conditions and storing their expressions and opinions in his wonderful memory. The prestige of his name, wealth and official title, enhanced by his rare intellectual gifts, gained him a welcome into the literary and political salons of Paris in its brilliant period before the revolution of 1848.

The book is but a dull substitute for the personal recital which, with its infinite charm of manner and language, remained to the last moment of the author's life a delight to his friends. The balls at the Tuileries; the salon of Madame Ancelot; the fancy ball at the Spanish Ambassador's; Louis Philippe; the old Maid of Honor to Josephine; de Tocqueville; Balzac; Lamartine; Casimir Perier, the famous physician; Koreff, the hangman of Paris; Mademoiselle Lenormant, and all the long list of historic Louisiana families then living in Paris, with their anecdotes and their experiences-many a dreary hour in his own life and in the lives of others he beguiled into a pleasant one by these reminiscences. He learned to know Paris as he knew New Orleans; and he loved it only second to his native city. But the cure he sought there he did not find and he was a chronic sufferer throughout his long life. 
Shortly after his return from France he married a beautiful, charming and most intelligent ladyMrs. Ann Buchannan, a member of the prominent Ricks family of Mississippi. The union proved a perfect one, although childless, and, as the husband always avowed with emotion, she was life's great compensation to him for the many disappointments and misfortunes he had suffered.

The absence, which apparently cost the loss of his services to the State for eight years, proved, on the contrary, a period of unexpected usefulness. As soon as his health permitted, he threw himself ardently again into the study of the history of Louisiana, working now, not from the material furnished by Martin and local traditions, but from the vast collections of historical documents lying stored in the archives of the Ministry of the Marine and Colonies in Paris-a field hitherto unexplored by American historians. His researches in it were so thorough that little of moment has been added to them by after gleaners.

Gayarré's family connections gave him access to private archives and documents that but for him would never have been exhumed. When he returned to Louisiana he brought with him, therefore, a new history of Louisiana practically complete. He wrote it in French to preserve the text of the official documents copied from the French archives, which form the bulk of the volume, and published it in New Orleans. The first volume appeared in 1846; the second, in 1847.

The work has been so long out of print that it is rarer now than the "Essai Historique," but covering, as it does, the official history of Louisiana from its 
colonization by Iberville to its cession by France to Spain, it is a treasure of reference to the student. The only rival it has in Louisiana bibliography is Gayarré's later and last history. A good appraisement of its value can be made by comparing it with other histories of the same scope published in the United States at that date, or for a score of years afterwards. Had it been written in the language of the country and brought thus within the reach of the ordinary writers and teachers, it is but truth to say that it would have elevated the standard of historical research of the time and advanced by a generation the method of the study of original documents that is the rule to-day. But it could not fail to awaken local enthusiasm and a revival of interest in the past of the State whose future greatness was becoming the political creed of the hour.

The work has its defects in the rigidity of a continuous series of copied documents. Even while composing it, Gayarré conceived the plan of a larger, freer, more comprehensive use of the same material, and the addition to it of a volume to be collected from American archives, and written in the language of the country.

At this period, the "People's Lyceum" (New Orleans having so far progressed in its Americanization) invited Gayarré to deliver one of its twelve annual lectures. As a bird from a cage, his heart seems to have bounded from the hard-and-fast confines of the official documents that encompassed him into the open air and flowery pastures of "The Poetry and Romance of the History of Louisiana." He culled from it not one lecture, but a series of lectures that form the first volume of the publication 
entitled "The American Domination." In his preface he confesses to a humble imitation of Sir Walter Scott in this use of the imagination as a bait to lure readers into a knowledge of history. Time abounds with such attempts and history has lost rather than gained from the concession of gilded facts to readers, for these prove generally the most annoying errors to get rid of afterwards.

In this case, however, the damage caused may well be overlooked in comparison with the good achieved. "The Poetry and Romance of Louisiana" is the portal through which most readers enter the history of Louisiana. If, thereafter, one never feels quite sure of the true reality of the realm one enters, if there happens to the reader what the author confesses happened to him, that in it the things of the heart became confused with the things of the mind, the gain has been that in Louisiana the popular sentiment for the history of the State is vivid and picturesque, and that there is not only a popular but also a true poetic sentiment for it that has made itself felt most notably in the educational systems of the day. As a source of inspiration to the dramatist, poet and novelist, it has been in truth too generously prolific. To withdraw its contributions, if such an experiment could be made, from the fiction and drama of the country since its publication, would produce indeed something like a collapse in our native pseudo-historical literature.

The second volume, "The French Domination," is also formed from a series of lectures, but the author says it is, so far as he could make it, detailed and accurate history; in other words, there are in it no adventitious charms. While, however, it holds fast 
to the chronological documents, it is not shackled by them. It rises out of them and above them, expanding with freedom and ease into a narrative that in truth gives such a full satisfaction of charm and interest as makes a Louisianian well-nigh afraid to express any other opinion of it than this-the difficulty is not how to praise it, but how not to overpraise it.

Meanwhile, by what in the experience of after time seems a political anomaly, Gayarré was twice chosen by the city of New Orleans as ner representative in the Legislature; and he was also appointed by two succeeding governors Secretary of State, a position he held for seven years. This period represents the proudest and pleasantest years of his life and also of that of the State, which was then in the full glow of her maturity as an American commonwealth. The friction between the old and the new population had duly changed rough into polished surfaces; the irritating chafing under the yoke of strange conditions had ceased, yoke and neck having become habituated to one another and "the life of the commonwealth," to quote the contented words of our historian, "was but a quiet, ever swelling stream of prosperity."

The banks of such a stream have ever proved fertile soil for intellectual culture, and they seemed to prove so then in Louisiana. But the stream of prosperity, alas! has found so many impediments in its course in the lifetime of the present generation (whose whole strength, indeed, has at times been devoted to keep a current alive in it) that it seems only a part of the usual vain and feeble boasting over an age gone by to say that great institutions, hand- 
some buildings, schools, colleges, public libraries, charities and noble private benefactions flourished then, with every promise of continuous development, where to-day the seed of them are being so laboriously resown.

There was, however, no consummation of that old and passed prosperity that commends itself so much to the student of to-day as the manifest appreciation, public and private, of the importance of the knowledge of the history of the State as an element in the wise development of the State. This is an idea that we are familiar with at present-one that has become a part of the educational outfit of every State of the Union. At that time, in Louisiana, Gayarré was the evangelist of it-and, rare as the exception sounds, he did not preach in a desert. Appropriations for a statue of Washington by Powers, to be placed in the rotunda of the Statehouse; for an equestrian statue of Jackson, to be placed in Jackson Square; for a monument on the battlefield of Chalmette; for swords and gold medals to Mexican War generals, adorn the legislative records of that period. They, all of them, bear the signature of Gayarré.

During his seven years in this office the Secretary of State had the expenditure of an annual appropriation of one thousand dollars for the purchase of books for the State Library. Gayarré's scholarly use of this money changed a mere accumulation of volumes into a library worthy of the name, whose historical section, even in its infirm and invalided condition to-day, commands the respect and admiration of scholars. Each rare volume in it bears the date of Gayarré's incumbency. 
Shortly after his return from France, he secured the purchase by the State of the historical documents copied by M. Felix Magne from the archives of the Marine and Colonies in Paris. The two bulky volumes, for which one thousand dollars were paid, are now the precious heirlooms of the Louisiana Historical Society, which was resurrected, in truth, to receive them and to carry on the work of further research under the new historical impulse.

Established in 1836, the historical society had languished and become inert from lack of the special direction of effort necessary in such societies for healthful activity; when Gayarré became Secretary of State he, with a group of friends, revived the society, reorganized it, adopted a constitution for it, and elected Martin, the venerable historian, President, with John Perkins, the wealthy benefactor of letters in Louisiana, and J. D. B. De Bow, Secretaries. If to the above names be added those of B. F. French and Edmond Forstall, the list of the century's eminent servitors of the history of Louisiana will be complete. It is a list the like of which will hardly be seen again in the annals of the society. French was the publisher of the "Historical Collections of Louisiana"; De Bow, the editor of "De Bow's Review," Forstall (of the old Creole family) was the author of "An Analytical Index of the whole of the Public Documents Relative to Louisiana Deposited in the Département de la Marine et des Colonies, et Bibliothèque du Roi, at Paris."

Perkins, delegated by the socrety to make researches in Europe for interesting historical matter relating to Louisiana, secured the services of Pierre Margry, the archivist, to make a transcript, 
chronologically arranged, of all the papers in the different archives of the French Government referring to Louisiana from the date of Iberville's landing to the time of its cession to the United States. This undertaking, vast as it proved to be, was superbly carried out by Margry; and the pride of the remark may be excused here, that it was to this commission of the Louisiana Historical Society that the historical students of the United States are indebted for what was a consequence of it-the compilation and publication of Margry's great and momentous work: "Découvertes et Etablissements des Français dans l'Ouest et dans le Sud de l'Amerique Septentrionale."

Pushing his influence farther, Gayarré obtained from the Legislature of 1847 an appropriation of two thousand dollars to be expended under the auspices of the Historical Society in procuring from Spain copies of original documents relating to the history of Louisiana. In his report as Secretary of State for 1850, he gives the account of the disbursement of this money and his correspondence with the United States Minister to Spain and with Sr. Pascal de Gayangos on the subject. Several packages dealing with the transactions of the Spanish Domination were received by the society, an addition of great value to those already possessed in Louisiana. The investigation, however, was not completed; another appropriation was needed which, notwithstanding the warm recommendation of the Governor in his message of 1853, was never passed. The adoption of a new Constitution in 1853 occasioned the retirement of the historian from his office and also, it may be said, the retirement of the State from its patronage of letters.

In 1854 the third volume of Gayarre's history, 
"The Spanish Domination," was published. This ended the colonial history of Louisiana. The fourth volume, "The American Domination," was begun at once, but finished only after the Civil War in 1866. He passed the years of the Civil War in retirement at his country place "Roncal," named for the old home of the Gayarrés in Spain. Here he wrote a life of Philip II of Spain, published simultaneously with "The American Domination."

"Fernando de Lemos" was published in 1872. In 1875 Gayarré was appointed by the Judges of the Supreme Court of Louisiana reporter of their decisions. This seemed at the time a blessed intervention, an opportunity for him. Looking back upon it through the corrective lens of years, the opportunity is seen as all in favor of the State; and futile resentment must ever be felt by the chronicler who is called upon to transmit the record that when, by some political exigency of the hour, the Supreme Court was superseded, the historian, whose reports were a model of their kind, was also superseded by one who was considered a more valuable political asset of the party in power. The record may as well be inserted here, for the sake of history, that whatever services Gayarré might have rendered his State, in exchange for what Goldsmith calls the best encouragement for genius-subsistence and respect, there was henceforth always a man younger, and of more practical use in politics, preferred before him. And history demands also that the fact be not omitted that Gayarré was twice an applicant for an insignificant position in the gift of the President of the United States, and that by two different Presidents negroes were preferred to him!

Notz.-One of the good stories of the war that Gayarre was fond 
of relating was that on the rumored advance of the Federal armyin camp not many miles away - he thought it only an act of the commonest prudence to follow the example of his neighbors and hide, that is, bury his valuables. He, therefore, packed in a secure tin box all that he selected as most precious to him: his wife's jewelry and diamonds and his treasured heirlooms; the shoe buckles and sword hilt studded with brilliants that belonged to his father; his grandmother's miniature in a frame surrounded with diamonds; de Borés snuffbox; in short, all the priceless innumerable trinkets of generations of his family. Selecting a good spot for the purpose under a tree that he could easily identify afterwards, he, accompanied by his wife, stealthily crept out to it in the dead of night but taking a lantern with them! His confidential body servant, "the most accomplished valet and rascal in the world," according to his master, easily suspecting what was in the wind, played the spy and watched the burial of the treasure. Gayarré could not sleep for thinking of his precious box under the tree; by morning he was at the spot to disinter it; but it was gone! And the valet and the carriage horses as well! The plunder was sold in the camp and for years afterward in New Orleans, William, the confidential servant, lived on the proceeds.

It is hardly necessary to add more at the present time, which is as yet but the morrow of a painful yesterday. The memory of it is still fresh and sensitive. Some day perhaps the suffering in it will be forgotten in the spiritual gain that comes to one generation from the example of ill fortune nobly borne in another. The pen, at best of times a frail support, became perforce Gayarré's staff of life. He had inherited, however, from his past days of fortune at least a well-known name and reputation. These stood him in good stead with the publishing world. In 1877 , he was requested by the editor of the North American Review to write upon "The Southern Question," then in its most acute stage in national affairs, as one who could and would treat it not from a sectional or partisan, but from a broadly historical 
point of view. He accomplished this difficult task with remarkable dignity and skill.

The Historical Society, which again had succumbed to neglect and impoverishment, was again revived by Gayarré at this time.

"Aubert Dubayet, or The Two Sister Republics," was published in 1882. As name and subtitle indicate, it is an historical romance connecting the American and French revolutions by means of one of Louisiana's favorite heroes-General Aubert Dubayet of the French Republican Army and Minister of War under the Directory. Like "Fernando de Lemos," it is a landmark of the past of Louisiana, and its value therefore one that time increases.

This last book was followed by a period of the most stringent necessity and, therefore, of the most incessant activity of the author's life. The everready market of the newspaper and magazine was a continual incentive to his energy, and for several years he was a steady contributor to it of such wares as he could furnish, mainly historical articles concerning the early life of the colony. The most noted of these are:

"An Historical Sketch of the Two Lafittes;"

"Historical Sketch of Washington's Surrender at Fort Necessity, to François Coulon Dumonville de Villiers, a French Finight of St. Louis (whose family has left descendants in Louisiana);"

"Seward on Reconstruction of the Southern States;"

"A Louisiana Sugar Plantation of the Old Régime;"

"The New Orleans Bench and Bar;"

"An Old Street in New Orleans;"

"The Norman on the Banks of the Mississippi;"

"Don Carlos and Isabelle de Valois;"

"The Creoles of History and the Creoles of Romance;" 
as well as numerous long and valuable articles in the current newspapers of New Orleans.

For three consecutive winters Gayarre lectured upon Louisiana history, at the request of a circle of patriotic ladies and gentlemen of the city. His record of work, which had lasted sixty-four years, drew to a close only a year before his life ended. Demands upon his time and his courtesy were still met generously as of old. Information was given, as it had always been, freely to all without discrimination, in spite of great abuses of such kindness in the past. A large correspondence was faithfully attended to; visiting strangers were received with unfailing cordiality; books, letters, manuscripts were placed at the disposition of any student that needed them. His memory never grew dim, for it was kept polished by incessant use. He was to the end always the last resource and authority in disputes over questions of Louisiana history. His circle of friends grew smaller as he lived on, outliving them; but the devotion of those that remained increased only the more. He passed away quietly, painlessly, his hand clasping the hand of his wife, to whom he had been united in a long and happy marriage, and who survived him until 1914, passing away in her ninety-fourth year in the fullness of a brave and beautiful old age.

He was buried in his grandfather's tomb, in the old St. Louis Cemetery. 


\section{CHAPTER XVIII}

\section{BOULIGNY}

THE Bouligny family, according to their superb 1 collection of family documents, one of the most complete in the historical annals of New Orleans, came originally from Milan. The name was Bolognini, and the founder of the family was Mateo Atendolo Bolognini, first Count of Bolognini, who married, in Milan, Ysabel Urcelli. One of his descendants in the fifth generation, Geronimo, married Ysabel Visconti, of the ducal house of Milan; and Maximiliano, in the eighth generation, married Julia Visconti. In the tenth generation, Francisco Bolognini was Captain of Cavalry in the service of Spain. He was made prisoner by the French and taken to Marseilles, where he changed his name to Bouligny. He married a French lady, Cecilia Germain, in 1649, and entered a commercial career. He was the father of Josef, who married Agnes Larchier and became the father of Juan, born in Marseilles, 1699.

After the war of the Spanish Succession, Josef settled in Alicante, Spain, where he died. The family thenceforward was Spanish. Juan, the only son of Josef, married Maria Pared of Marseilles in 1724. He was the progenitor of the Louisiana family and he was a man of influence. He had five sons and six daughters. The oldest son, Josef, became a wealthy merchant of Alicante; the second 
son, Juan, became Spanish Ambassador at Constantinople and died in Madrid, in 1789, Honorary Councillor of State. His son Josef was Ambassador Plenipotentiary of Spain at Stockholm. The third son of Juan was Francisco, who came with O'Reilly to Louisiana. The fourth and fifth sons, Louis and Lorenzo, were captains in the Spanish Army. The Boulignys occupied high positions in Spain, and became connected by marriage with the noblest families. The father of Francisco was on intimate terms with General O'Reilly, according to his letters to his son.

Francisco Bouligny was born in Alicante in 1736; he entered the Spanish Army in 1758 as cadet in the infantry regiment of Zamorra, serving two years; and was then transferred to the Royal Guards, serving one year and nine months. In 1762 he was sent to Havana, where he remained seven years. In 1769 , he came to Louisiana as aide-de-camp to O'Reilly. History relates that he first set foot in New Orleans on the night of July 24th, bearing a communication from General O'Reilly to Aubry, the Governor. His barge landed in front of the Place d'Armes, where stood awaiting him the Spanish officials, Gayarré, Navarro and Loyola, who received him with open arms and immediately conducted him to the hotel of Aubry, to whom he delivered and translated the letter he bore.

But imagination, clinging ever to history like a child to its nurse, chattering its artless questions and wonderments, cannot and will not be satisfied with merely the necessary information. The way from the Place d'Armes to the hotel of Aubry leads over the distance of but a few squares or "Islets," 
as they were called, in the very heart of the little city. Bouligny, glancing about him as he walked along through the crowded and excited streets (Gayarré says that no one went to bed that night), could not but have noticed the fine manner and courteous bearing of the men who made way for him and his companions, saluting them respectfully. It was a July night and the doors and windows of the low, picturesque houses must have been frankly open, revealing their handsome, luxurious rooms, set with fine-carved furniture and rich ornaments, with negro slaves moving about in them bearing trays of refreshing drinks in crystal glasses. And through the open windows he must have had glimpses of beautiful Creole faces, wan with anxiety and care, awaiting with fear in heart the purport of the very missive he was bearing - tidings that he, perhaps, knew were as a lifted sword over the citya sword to drip with blood.

The soft, warm air of the July night, heavy with the fragrance of jasmine and oleander and belated blooms of magnolia, the dusky green of gardens about him, the giant forms of moss-laden oaks left over from the forest, the gorgeously brilliant stars overhead could not but work a charm upon him. He was thirty-three, handsome, and gallant as all Boulignys were and are at thirty-three. The beautiful Creole faces, wan with anxiety, must also have been not unconscious of him as he passed by. What his friends told him casually of the city he had come to (where they had been living three years), and of its society, could not but have chimed in harmoniously with the impressions he was receiving.

History vouchsafes to say that he dined the next 
day with the Governor and met the most important and influential of the citizens-especially those who had been conspicuous in the revolt against Ulloaand that Aubry had taken the occasion to assure him that the hotheads among them had returned (in plain words) to their senses and that the Spanish ruler had no more to fear from them. Hearing that Lafrénière and Milhet intended to present themselves in person to O'Reilly and assume responsibility for the conduct of the guilty citizens, he offered to accompany them and present them himself to the General (who was, as we have seen, a friend of his father's). It took them forty-eight hours to reach the Spanish vessel at the Balize and at the end of the journey they must have learned to know one another. Bouligny was present at the interview, in which the Creole gentlemen showed themselves no whit behind the Irish-Spaniard in dignity or in address.

Bouligny has left his report of the interview, and tradition, of course, repeats more than he ever said that his heart was then frankly moved in favor of his new friends. He was present at the dinner that O'Reilly gave to his Creole visitors and, from the suavity of the General's manner, was persuaded that, as he said, "all was forgiven and forgotten."

"How beautiful upon the mountains are the feet of him that bringeth good tidings, that publisheth peace!" More beautiful tidings or bringer of them have never come upon the Mississippi to New Orleans. From the depths of despair the little city rose to the heights of confidence. O'Reilly's ruse had succeeded and he could proceed now with his 
game as he had planned. The leaders, all unsuspecting of a trap, walked into his presence in answer to an invitation and were instantly disarmed and conducted to a prison which they never left except for the place of execution. The form of a trial was gone through with and the sentence, pre-decided by the military governor, was pronounced. The incredulity of the citizens passed into a stupor which was not dissipated until the shots of the firing squad were heard in the barracks yard.

Bouligny joined his efforts to those of his friends, Loyola, Gayarré and Navarro, to obtain a commutation of the brutal sentence or at least a suspension of its execution until the government in Spain could be heard from; but they, like the patriots, had to bow to O'Reilly's cruel will. "If rulers but imagined what visions coming time would show!" The lilies of France never bloomed more luxuriantly in Louisiana than after Spain threw upon them the blood of the Creole patriots. Even the flag that O'Reilly hoisted to the tall staff in the Place d'Armes drooped as if in shame before them.

Love makes a quick growth when sympathy prepares the ground. During the next year, Francisco Bouligny was married to Marie Louise le Senechal d'Auberville. She was the best that the city could give him and in beauty and lineage worthy of all that he could offer. She was the daughter of Vincent Guillaume le Senechal d'Auberville, Marine Commissioner of Louisiana and of Françoise Petit de Levilliers de Coulange.

The Sieur d'Auberville was born at Brest in 1713 . His father was Louis d'Auberville; his mother, Marie d'Ayme de Noailles. The Sieur de Noailles is well 
known in Louisiana history. He was the officer in command of reinforcements sent to Bienville in the Chickasaw war in 1738; and Bienville was commanded to act with him and even under him, as he was a man "with the talent and experience necessary for command." The result produced was disunion between Bienville and Noailles; and, in consequence, the failure of the expedition. He was the brother of Marie d'Ayme de Noailles and uncle of the Sieur d'Auberville.

The marriage contract of the Sieur d'Auberville and of Marie Françoise de Levilliers de Coulange is still in existence, signed by the Marquis de Vaudreuil. The family of Petit de Levilliers de Coulange goes back in the documents of the Bouligny family to Etienne Petit, "Grand Audiencier de France" under Louis XI. Claude de Coulange," Seigneur de Bustance en Auvergne," married Madeleine d'Aguesseau of the family of the great Chancellor d'Aguesseau. (It will be remembered that the mother of Madame de Sévigné was a Marie de Coulange.) After the death of the Sieur d'Auberville, in 1758, his widow married the Chevalier Pierre Gerard de Vilemont.

Among the letters preserved by the family is the one written by Don Francisco's father to him on his marriage:

"My very dear Son:

“Alicante, June 12, 1770.

"Your letter which I received on May 26th, informs me of your marriage with Miss Louise d'Auberville, daughter of the French Intendant-General of that Province, aged twenty years, well-bred, and of infinite merit, which $I$ approve in wishing you all kinds of happiness and benediction in your new condition. May God have you in His holy protection in good health and good union and grant 
you what you may need. Give her a kiss for me as I cannot do so personally on account of the distance. Receive the benediction of your father,

"Jean Botligny."

Another letter on the same occasion comes from the commanding General, O'Reilly:

"Madame:

"I shall always be interested in your happiness and will give you with pleasure all the proof of this that depends upon me.

"I felicitate you upon your marriage. Your husband is a worthy officer whom I esteem; I hope you will be happy together. It is because I am persuaded of this that I wish you joy in your union.

"I have the honor to be, very respectfully, Madame,

"Your very humble and very obedient servant,

"O'Reilly."

Among the papers preserved are no less than twenty-seven letters written by the Baron Carondelet; some of them on subjects of high political importance, such as the incredible conduct of Genet, the French envoy, and the rumor of an uprising of the slaves; others on subjects pleasantly convivial, such as accepting Bouligny's invitation to dinner on Sunday, from which, if it is to be ceremonious, he begs to be excused, but if it is to be merely friendly and in the family he accepts, "muy gustoso"; assuring his hosts that it would be a pleasure to eat with them whenever he had a moment of relaxation, but on the condition that no ceremony will be made over him, for what he seeks is the pleasure of their society, etc., etc.

Bouligny rose in grade to "Coronel Vivo," and was made a Knight of St. Charles. He served with distinction under Galvez in his famous little war against the English, was present at the capture of 
Baton Rouge, at the siege of Mobile and at the final triumph over Pensacola, when he took the fort by storm at the head of his company and was rewarded for it especially by the King. He acted as Governor of Louisiana in 1784, during the absence of Governor Miro; and, in 1799, on the sudden death of Governor Gayoso de Lemos, he, as Colonel of the Regiment of Louisiana and senior military officer of the province, assumed the military administration of it. He died while occupying this position, according to his certificate of death signed by Fray Jose de Agostin, on the 7th of August, 1802, ending a good and valuable life. A voluminous report to the King of Spain on the condition of Louisiana written by him has never been translated or published; although, beyond a doubt, of great interest and importance to historical students.

After his death, his widow wrote to her niece, the Señora Dona Clementina de Bouligny y Pizarro (daughter of Juan Bouligny, the Ambassador), asking to be facilitated in her desire to remove to Havana, "believing that the province would form a component part of the Spanish Domain we have clung to this time, in this fond hope." This shows the persistent opinion maintained by the Spanish officials that Louisiana would never be alienated from Spain.

Francisco left four children: one daughter, Marie Louise Josephine, who married the Chevalier de la Roche, an officer in the militia; and three sons, Dominique Charles, François Ursin, and Louis. Louis married Isabelle Virginie d'Hauterive, of the old and distinguished Louisiana family of that name. Dominique served in his father's regiment and with it passed over to France and later to the government 
of the United States. He married Anne Le Blanc. $\mathrm{He}$ was one of the prominent Creoles selected to serve in the Legislative Council of the Territory by the House of Representatives on Governor Claiborne's recommendation that he was a "young man of sense and supports a good character." It is always mentioned of him, and it was a distinction at the time, that he was educated in the public schools of the city.

Dominique served on the Committee for Public Defense during the British invasion of 1812 . He served also as the United States Senator for Louisiana from 1824 to 1829 . He died in 1833. Six sons and six daughters survived him to follow out, as he had done, the admonition that Don Francisco's father wrote to him from Spain: after describing the escutcheon of the family, he says, "the principle nobility is to be 'hombre de bien,' of deeds without reproach, to live in the fear of God, obeying His commands."

The sons of Dominique were Ursin, Gustave, Edouard, Henri, Alfred, Dominique. Both sons and daughters married as beseemed their high family and social station, founding families that have spread like a fruitful vine over the society of New Orleans, enriching it and garlanding it with beauty. To unwind the thread of their marriages is to untwist the tendrils of the vine; all branches ascend to or descend from the great patriarch Dominique, the son of Don Francisco and Louise d'Auberville.

The men seek not brilliant positions or political distinctions, but though always found in the line of public duty, live and thrive each one in his own home spot, in quiet solitude. Nevertheless, two or 
three names have burst the narrow confines of home. Among them is that of John Edouard Bouligny, born in New Orleans in 1824, a nephew of Dominique, and like him a lawyer and educated in the public school; was elected to the thirty-sixth Congress from Louisiana, serving in 1861. He was the only representative from the seceding States who, at that time, did not leave his seat. He died in Washington in 1864.

Ever to be remembered with gratitude by Louisiana historical students is the name of Arthemise Bouligny, the daughter of Gustave and Octavie Fortier (daughter of Edmond Fortier and granddaughter of Colonel Michel Fortier, who was an officer in the regiment of Don Francisco). She married one of the great American financiers and merchants of New Orleans, Albert Baldwin, and for years reigned as a leader in the social world by virtue of her great beauty and vivacious mind. She it was who collected from the many treasuries of her large and scattered family the numerous documents and letters that form the imposing genealogical record of her family. She had them transcribed and opened them to the Louisiana Historical Society, of which her cousin, Alcée Fortier, was President. The collection descended by inheritance at her death to her son, Henry F. Baldwin, and are now in the possession of his widow (born a Vainin).*

* By a curious historical coincidence, the Vairin family trace their ancestral line back to the same Claude de Coulange, Seigneur de Bustance, who married into the family of the great Chancellor d'Aguesseau, and was therefore a connection of Madame de Sérigné. The history of this interesting (Vairin) family, although not relating to Louisiana, is omitted here with sincere regret and only for the reason that the prescribed limits of the book do not permit its insertion. 
Two other names are inscribed in memory to the credit of the family-not in its historical annals but soaring above in the blue sky of art: Corinne, the exquisite Spanish brunette, perfect in witchery and grace, who conferred upon the city the joy of a voice that it might well glory in and that it did glory in. Such was its transcendant beauty and gift of exhilaration that, in her day, it was said as a truth and so believed, that those who heard her forgot life itself. Before her notes, sorrow took flight and mourning dropped its black. She was the daughter of Alfred who, it may be recalled, was mortally injured in the tragic accident that befell the old Orleans Opera House, when on a gala night the crowded balcony fell, crushing all who were seated beneath. Her mother was a Pitot; she had, therefore, the best parentage for talent and beauty the city afforded. She married, in the height of her youth and fame, James Nott, who died before either had faded. She has moved from her native city to live with her son in the State of Georgia.

As if to prove the richness of the vintage of the good family vine, there soared almost simultaneously in the blue above another songster, another Bouligny-"Lucie." She was grave, fair and blonde, ethereal, with a smile of angelic sweetness, like de Musset's "Lucie" (to those who knew their de Musset):

\footnotetext{
“. . . . Elle etait pale et blonde

Jamais deux yeux plus doux n'ont du ciel le plus pur Sondé la profondeur et reflechi l'azur."
}

She had a voice, in truth, such as the poet called for, "that sounded like enchanted wine loosening 
her notes in a silver shower," a voice that came not down to earth or mortality but lifted the hearer above to heaven and immortality. Her art came from Italy who received it, as we know, from heaven. It was given her by the matchless artist who in the last century was sent to the music-loving city by a music-loving providence. Calvé, she was called in her youth, when she was the pupil and friend of Rossini and the "first prize" of the Paris Conservatoire. For a lifetime, to the verge of her old age, she was loved, honored and almost worshipped in New Orleans as a very goddess of lyric music. To Lucie, one of her favorite pupils, she gave of what she had received in good measure, pressed down and running over, and the good scholar has passed on the good measure of art to her own pupils, maintaining the standard of perfect singing among the Creoles with the same devotion that the standard of old customs and manners is maintained.

Lucie was the daughter of Dominique and of his wife, Celestine Conway. There were seven daughters, all beautiful and talented: Lucie, Anna, Lizette, Jeanne, Léa, Angèle, Marie, all educated with finished care and moving with dignity through the life before them-a life from which their father had departed, shorn of the fortune which had been his of right and which should have been his daughters. Jeanne married Oscar Crosby-recently a member of the diplomatic family of President Wilson. His beautiful daughter is now the wife of Count Caracciolo. Lucie married Louis Arnauld, a young lawyer of prominence, who could have boasted, but never did, of his descent 
from the great Arnauld of France. He died in the full career of his professional and domestic happiness, leaving his young children to the care of his wife.

Madame Arnauld's beautiful voice faded and passed away, but the artist remained and the woman and the mother; a sample through the fading, wearing years of the fadeless brocade of which old court dresses and Creole families were made. In her little home that, despite its American neighborhood and American building, recalls vaguely the little homes that were first built in the city, where the front door opens without ceremony into the little garden and that into the street; where the front room is the salon-such a salon as Don Francisco must have glanced into as he hurried through the streets of New Orleans for the first time, bearing despatches to Aubry from O'Reilly; when his glowing eyes sought through the open windows a sight of the lovely Creole faces awaiting with anxiety the news that he was bringing. The sight of just the same lovely faces would be granted him now through the open window of his great-great-granddaughter. There was no music in the houses then, but now he could have heard voices and music of the kind that vibrates in the heart and memory ever afterwards. No soft-footed black slaves bear around silver salvers of refreshing drinks; but the traditional anisette is passed, nevertheless, in their minute glasses, in the true old Creole fashion.

And could Don Francisco but have peeped in one December night of the year 1918! Could Louise d'Auberville but have looked with him on the little salon, when the gay French conversation suddenly stopped, and the singing, while through the door 
from the street entered a young soldier in uniform, wearing the "fourragére," handsome of face, perfect of figure, his breast covered with decorations, blushing, and childishly shy of meeting strangers after four years of war-Edgar! Edgar Bouligny! Ah, he had made his city and his people proud! The first American to enlist in the Foreign Legion, the hero of its heroes, his picture and his record in all newspapers! Covered with wounds as with decorations, and not yet twenty-three! It was a moment of triumph for the Bouligny family. The banners of France and America waved then in all hearts in that little salon, and down the generations leading back to Spain, Spanish banners must have been waving, too, in salute to Edgar Bouligny.

He is the son of the Edgar who was the only brother of Lucie Arnauld who married Lucie Delery des Islets, of the great family of Chauvin who gave the hero, Nicholas de Lafrénière, to Louisiana. The heart wishes that he, too, could have stood with Don Francisco and Louise d'Auberville to see their descendant! 


\section{CHAPTER XIX}

\section{ALMONASTER}

\section{$\mathrm{D}$}

ON ANDRES ALMONASTER Y ROXAS was a native of Mayrena in Andalusia, Spain. His parents were Don Miguel Jose Almonaster and Donna Maria Joanna de Estrada y Roxas, both of noble birth and ancient lineage. He came to Louisiana in the suite of O'Reilly and was made Colonel of the Provincial troops; and he was afterwards appointed King's Notary, or Notary Public.

In 1769, when the new Spanish Government was inaugurated by O'Reilly, he was given the office of Alferez Real or Royal Standard Bearer, a merely honorary office with no other function assigned to it but the bearing of the royal standard by the incumbent in great public ceremonies. He was afterwards invested with the royal and distinguished Order of Carlos III (as described in Pontalba's letter to his wife). A full-length portrait of him is shown to-day in the Cabildo at the head of the great stairway. A sturdy, strong personality it represents: shrewd of face; standing erect as a royal standard bearer should, with his cocked hat under his arm and knightly sword in his hand; in court dress, with the Royal Order on his breast; a personage to command respect; self-important and selfsufficient. He was, nevertheless, not more important to himself than he became to the city of his adoption. $\mathrm{He}$ was the princely benefactor of New Orleans 
during its colonial period and, in truth, has reaped a reward in the shape of immortality that other and even more princely benefactors of greater cities might envy.

The beginning of the making of his great fortune has never been made clear, although suspicion has not been idle in presenting many origins for it. What is really known is that O'Reilly granted to the city in the King's name the ground on both sides of the Place d'Armes, from the Levee to Chartres Street, having a frontage of three hundred and thirty-six feet on the Place and a depth of eightyfour feet, and that Almonaster erected upon this ground a row of brick buildings that he rented most profitably for stores with residences above. $\mathrm{He}$ became also the owner of a large brickyard which he worked with his own slaves, and he soon was known as possessing great wealth. When in 1779 a terrible hurricane swept away the humble hospital building, which the sailor, Jean Louis, had founded in 1737, Almonaster had another one erected with a chapel at the large cost (for that day) of one hundred and fourteen thousand dollars; and in $\mathbf{1 7 8 7}$ he donated a chapel to the Ursuline Convent.

In 1788 , when the greatest conflagration the city has ever suffered destroyed the parish church, built in 1724, Don Andres made an offer to the Cabildo to rebuild it on a grander scale at his own expense. Such an offer meets only one answer. The reconstruction was at once begun, and in two years the Cathedral was completed, such as it stands to-day, or would stand had not the rude hands of ignorant architects in 1850 sought to improve and embellish it. On Christmas of 1794, the new 
Cathedral was dedicated with great pomp, according to the description of the ceremonies left by Don Joaquin de Portillo, the rector of the parish, who records that it owes its existence to the zeal and piety of Don Andres Almonaster. "who is almost without an equal."

"At the opening of the ceremony," so proceeds our record, "our illustrious benefactor presented the keys of the church to the Governor (Carondelet) who then handed them over to me." The fame of Almonaster, says the latest historian of the Cathedral, Chambon, did not fail to give offense to some less fortunate or less generous than he, who misrepresented his intentions and suspected him of ambition. But former Governor Miro, his friend, then in Spain, referred the matter to the King, who speedily put an end to such talk and rewarded the generosity of Almonaster as became his merit. The King wrote, "He is authorized to occupy the most prominent seat in the church, second only to the royal 'vice patron,' and to receive the kiss of peace during the celebration of Mass . . . he is to be given loyal support and aid in whatever he may undertake, is to be treated in future with deferential regard as one who has found grace near my royal person (grato a me real persona), by the achievement of great works, generously drawing upon his own resources for the construction of the parochial church, the Ursuline convent, the charity hospital and the government buildings of New Orleans;" signed: "El Rey."

The government buildings referred to by the King

Noтe.- "In and Around the Old St. Louis Cathedral," by the Rev. M. Chambon. New Orleans, 1908. 
are the Presbytere on the left of the Cathedral, now used as a part of the State Museum, and on the right of the Cathedral the Town Hall and Jail, now given over to the use of the Louisiana Historical Society, whose monthly meetings are held in the great Sala Capitular of the old Spanish Cabildo, the venerable and venerated room in which the ceremony of both the transfers of the colony took place and its final cession by France to the United States. It has suffered less at the hands of restorers than has the Cabildo, and is a better example of the fine architectural taste and skill of its builder. Don Almonaster's own slaves constructed it under his supervision. They prepared the timber for it and forged the iron work used in it, but his was the plan and his the genius for its execution. All honor be to him!

At sixty, Don Andres was in station the highest individual in the city and, indeed, in the province, by virtue of his great wealth and wonderful fame as a benefactor. But he was not married. This he accomplished also, satisfying, as in his buildings, no mean ambition. He sought and obtained the hand of the beautiful sixteen-year-old Louise de la Ronde, the daughter of the Marquis de la Ronde, a spoiled and petted belle. Society smiled and even laughed and in fact never ceased to play with its wits upon the (to society) ill-assorted couple. But he laughs best who laughs last, and Louise de la Ronde, the richest woman in the city and the foremost by virtue of the official dignity and solid worth of her good husband, could smile and laugh long after it at the best of her critics.

De Pontalba sent to his wife in Spain many a 
sarcastic reference to her and to her entertainments; nevertheless he was pleased to marry his son to the daughter that blessed the Almonaster marriage, and though he squabbled with the old Spaniard over bargains about brick and building contracts, still he indulged in no feeling of estrangement from him. The benefactor of the city died three years after the completion of his Cathedral and its pompous consecration, in the seventy-third year of his age, while his adored daughter, Micaela, was still in infancy. The tragedy of his life was that he died so suddenly that it was impossible to administer to him the last sacraments of the church. His tomb had been prepared for him by his grateful beneficiaries at the foot of the altar of the Sacred Heart in the Cathedral, but, according to a tradition full of pathos, he left instructions to place his body in the cemetery outside, as he felt unworthy of the honor intended for him and felt that he deserved no more than the humblest Christian in the parish. It was done as he prayed, and only after a probationary period, as it were, outside, was he conveyed inside the Cathedral to the vault covered by the slab that to-day bears his coat of arms and the record of his life, titles and services. The carved letters, though almost effaced by the tread of many generations, are still visible. His epitaph is written in Spanish, which, translated, is as follows:

Here lie the remains of

Don Andres Almonaster y Roxas

A Native of Mayrena

In the Kingdom of Andalusia

He died in the City of New Orleans

On the 26th day of April, 1798 
Being 73 years of age

A Knight of the Royal and Distinguished

Order of Charles III

Colonel of the Militia of this department Alderman and Royal Lieutenant of this Corporation

Founder and Donor of this Holy Cathedral

Founder of the Royal Hospital of

St. Charles and of its Church

Founder of the Hospital for Lepers

Founder of the Ursuline Convent

Founder of the School for the Education of Girls

Founder of the Court House

All of which he had built at his own expense

In this City

Requiescat in Pace

His wife and daughter inherited his great fortune which measured above any fortune hitherto known in the city, but it brought them only the enjoyment of wealth, not happiness. Micaela, when seventeen, was married to the young Celestin de Pontalba, son of the distinguished and aristocratic Baron de Pontalba. The match was considered a perfect one at the time; and was called the most important marriage that ever took place in New Orleans. It turned out, however, calamitous for both parties to it.

Madame Almonaster, after her daughter's marriage, bestowed herself and her fortune upon the young French Consul stationed in the city, $M$. Castillon, a man much younger than she; for which infringement of good taste, as it was considered, she was made the victim of a charivari greater than ever known before in the city, and the like of which has never been attempted since. For three days the unfortunate couple were chased by the truly infernal racket of bells, horns, drums and every 
noise-producing instrument available. They tried every avenue of escape in vain. A stranger, arriving in the city at the time, describes the wild excitement that prevailed; the streets were blocked, all traffic was suspended and, in short, the life of the populace was given over to tormenting Madame Castillon until she capitulated and paid the ransom exacted for her marriage.

Even the sedate Governor Claiborne pauses in a letter to President Monroe, March, 1804, to mention it.

". - The young and giddy were engaged in a charivari at the expense of an old widow" (she could not have passed her midforties) "who has lately married a young man . . . a Madame Don Andres Almonaster, whose annual income is about forty thousand dollars. The young men are determined to persecute the married pair until they agree to give a splendid fête to the genteel part of society and one thousand dollars to the poor of the city. It is expected that these terms will be agreed to."

\section{A passing stranger describes what he witnessed:}

". . Charivaries are still practised. They consist in mobbing the house of a widow when she marries, and they (the mob) demand a public donation as a gift. When Mme. Don André was married she had to compromise by giving three thousand dollars in solid coin. On such occasions the mob are ludicrously disguised. In her case there were effigies of her late and present husbands in the exhibition drawn in a cart . . . the former husband in a coffin, the widow represented by a living person . . . sits near it. The house . . . mobbed by the people of the town vociferating and shouting . . . hundreds on horseback; many in disguises and masks, and all with some kind of discordant and loud music such as old kettles, shovels and tongs and clanging metals can strike out. Everybody looks waggish, merry and pleased. Very genteel men can be recognized in the melee; all civil authority and rule seems laid aside. . . . This affair, as an extreme case, lasted three days, and brought in crowds from the country. It was made 
extreme because the second husband was an unpopular man of humble name, and she was supposed to have done unworthily. . . The whole sum was honorably given to the orphans of the place. . . . At a later period, the great lawyer Edward Livingstone (who married the beautiful Louise Moreau de Lassy née d'Avezac de Castera) received a charivari, but on this occasion the married pair came out promptly to the balcony and thanked the populace for their attention, and asked them to walk into the courtyard and partake of the good cheer provided. The compliment was received with acclamations and good wishes in return were made for many years of happiness to the married pair, and the throng dispersed in a good humor." Note-Diary of John F. Watkins, quoted in "History of Louisiana," by Alcée Fortier.

Madame Castillon, with her husband, shortly afterwards took her departure for France, where she joined her daughter. She died in France in 1827 and was buried there. 


\section{CHAPTER XX}

\section{DE LA RONDE}

PIERRE DENIS DE LA RONDE, the father of Madame Almonaster, was born and baptized in Quebec in 1726. He was the son of Louis Denis, Sieur de la Ronde, Captain of a company in the Marine, and Chevalier of the Order of St. Louis. His mother was Dame Louise Cartier de Lotbinière; his godfather was Pierre de Rigaud de Vaudreuil, who afterwards became Governor of Louisiana.

The line of the family descends from Simon Denis, Seigneur de la Trinité, grandson of Mathurin Denis, who was married twice, his first wife being Jeanne du Breuille, sister of the Procureur du Roi in Tours in 1661. From them descend the Louisiana branch of the family, headed by Pierre Denis de la Ronde.

By his second wife, Françoise du Tertre, he had twelve children, all living at his death. They, according to the family genealogy copied from certified documents, filled important positions in Tours, where they married into the families of nobility. Their arms are still to be seen on a great house in old Tours facing the public square: they consist of a bunch of grapes on a field "gules" supported by two stags, and they are also carved in the nave of a little chapel near one of the gates of the city. Their tomb is near the altar of the Virgin; it is of stone with the arms of the family applied in brass. Their patent of nobility was accorded the family in Quebec, in 1691 . 
When Pierre Denis de la Ronde came to Louisiana is not definitely known. The first mention of his name occurs among the officers under Bienville during the early days of the settlement of the colony. In 1769 , the Chevalier de la Ronde, retired Lieutenant of Infantry, signed the petition addressed to the Superior Council asking the expulsion of the Spanish frigate that, since the retirement of Ulloa, had remained stationed in the river, "a constant menace and source of vexation to the inhabitants of the city."

He married Madeleine Broutin about 1727. She was the daughter of the royal engineer under Bienville who was connected by marriage with the great families of Marigny and de Pontalba. She was also the widow (the second wife) of de Lino de Chalmette. Their home, undoubtedly the most beautiful plantation home in Louisiana at that day, was called Versailles. It lay below the city at the distance of a pleasant drive. Its picturesque ruins can be seen to-day. They recall vividly what the place must have been in the past, and speak eloquently of the refinement and elegance of the family who built it and lived there.

The beautiful Louise de la Ronde, who became the wife of Almonaster, was born there, and as a child played under the shade of the magnificent avenue of oaks which still defy the aging of time. When the famous invasion of Louisiana by the English took place and New Orleans was threatened with conquest, de la Ronde was a Colonel in the Louisiana Militia and, as such, in the forefront of all the measures of defense. When the English 


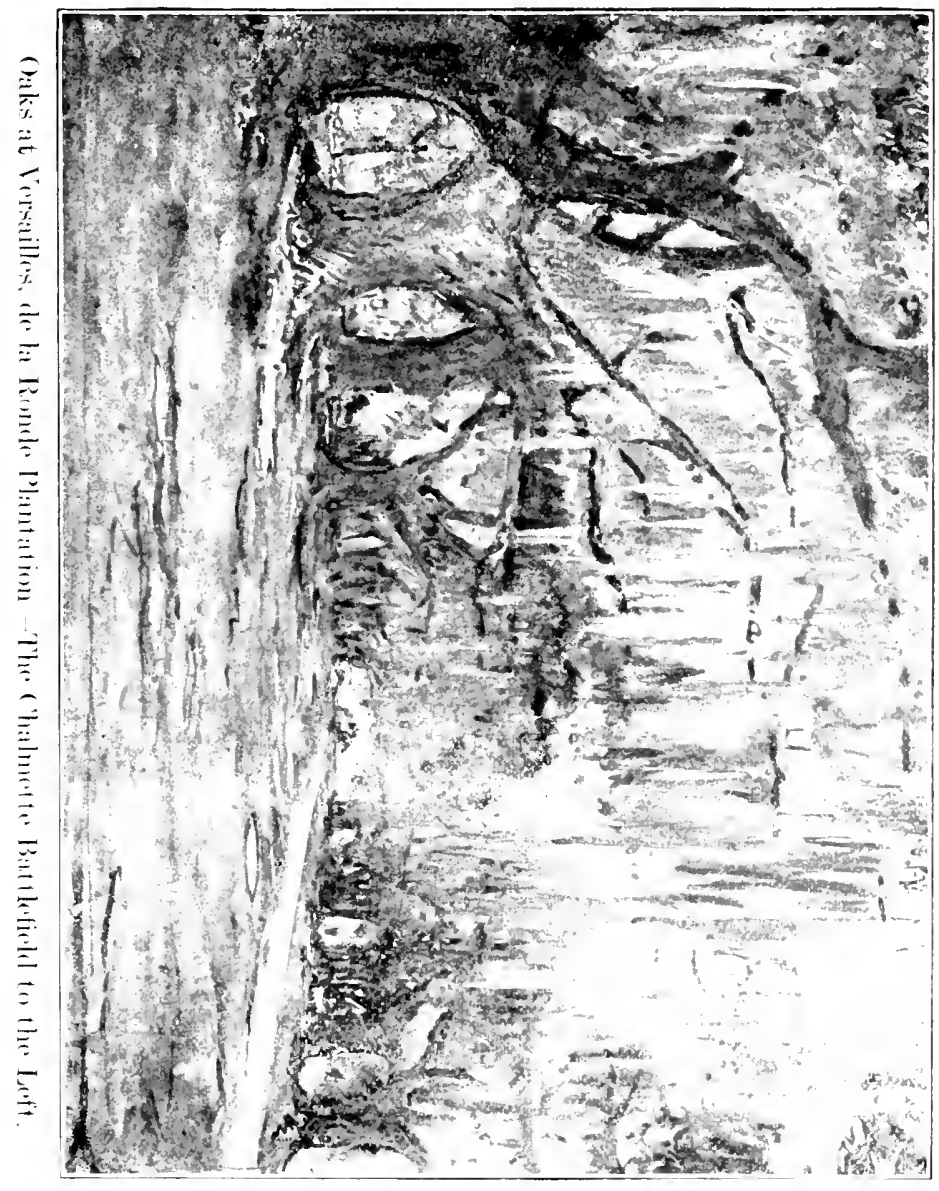



effected a landing from the lake in the rear of the city and stole up a little bayou that brought them to the plantation canal, and so to the Villeré place, the de la Ronde plantation was one of the five plantations that lay in the way of their advance to the city. When Gabriel Villeré, as may be remembered, made his dashing escape from his British guards, he sped to the next plantation, de la Ronde's, and there found Colonel de la Ronde, who himself had just rushed in from his command at Chef Menteur on the lake with the news of the British landing. The two officials jumped in a skiff at the river bank, crossed the stream and, seizing horses on the other side, spurred to the city where, covered with mud and breathless from their ride, they made their report to General Jackson, surrounded by his aides, that "the British were encamped on the soil of Louisiana"! To repeat the old, old anecdote which can never be too often repeated in the estimation of Louisianians-at the close of the report, the General drew up his figure to its full height and with an eye of fire and an emphatic blow with his clenched fist upon the table, swore his oath: "By the Eternal, they shall not sleep on our soil;" and turning to his aides, "Gentlemen, the British are below; we must fight them to-night."

The Chalmette plantation has gained the honor of naming the great victory, but the attack and the retreat were made through the de la Ronde place; and many a gallant British officer and soldier breathed his last under the soft shade of the old oaks whose great trunks still carry the scars of cannon balls and even the balls themselves. De la 
Ronde fought at the side of General Coffee on his own land. There is a tradition* in the family that it was de la Ronde who overheard the British officers giving the password for the night, "Beauty and Booty," and that he conveyed it to the American Army, thus furnishing them with the deadliest motive that fired their fury against the invaders.

The son of Colonel de la Ronde, Pierre Denis de la Ronde, was born in New Orleans in 1762, married Eulalie Guerbois, daughter of Louis Alexandre Guerbois and Elizabeth Trepagnier: he died at Versailles plantation in 1824. He had one son, who had no children; the name is therefore extinct. The nine daughters all married and have left children. Eulalie married a Hoa. Céleste and Héloise became the first and second wives of Maunsell White of Kentucky. Felicie married a Jorda. Amélie married a Forestier. Other daughters married into the Ducros and the Villere families; and another one became the wife of General Lacoste, whose plantation adjoined Versailles. Eliza White, the daughter of Céleste de la Ronde, the first wife of Maunsell White, was the mother of the Hon. Cuthbert Bullitt of Louisville, Kentucky. Héloise de la Ronde, the second wife of Maunsell White, had three children; Clara, Maunsell and Annie. Clara married the late Carl Kohn of New Orleans and had one child, Eveline, who married the well-known merchant of New Orleans, Victor Meyer. They had six daughters: Hilda, Clara (Mrs. McCaleb), Eveline, Mildred, Lenore (Mrs. John Hickey), Virginia. Two sons died in infancy. Maunsell White, Jr., married Eliza-

* Affirmed also by Vincent Nolte in his "Fifty Years in Both Hemispheres." 
beth Porter Bradford; their children are: Lucy (Mrs. C. P. Wilkinson); Mary (Mrs. A. R. Brousseau); Carl White married Mary Mitchell of Cincinnati (seven children); Sidney Johnson, married to Ellen Tobin of New Orleans; Elizabeth, married to Edwin Rodd of New Orleans; Anna, married to Thomas H. Anderson of New Orleans; Annie White, married to Hugh Kennedy. 


\section{CHAPTER XXI}

\section{CHALMETTE}

THE ancestry of Chalmette, a name of glorious 1 memories in New Orleans, has been traced as follows: Claude Martin Sieur de Lino; married Antoinette Chalmette of St. Nazaire. She died and was buried in Quebec in 1731. Their son, Mathurin François Martin, Sieur de Lino, a Councillor of the Sovereign Council of Quebec, was born and baptized in Quebec in 1657, and married Catherine Noland, daughter of the Chevalier Pierre Noland and Catherine Houart. Their son, François Martin de Lino, Attorney-General of the King, married, in 1712, Angelique Chartier de Lotbinière, daughter of René Louis Chartier de Lotbinière, Councillor and Lieutenant-General in Canada.

The Chartier de Lotbnière family, it would be inexcusable not to mention it, belonged to the old French family which bore the famous poet, Alain Chartier, famous not only for his poetry but for the pretty anecdote about him which has survived and which outshines his poetry. It is said that he was kissed by a Queen of France while asleep (Marguerite of Scotland, wife of the Dauphin, afterwards Louis $\mathrm{XI}$; one of the "three Marguerites" of French history.) Her attendant ladies remarking to her that he was the ugliest man in France, "I am not kissing the man," she answered, "but the lips from which so many beautiful words have come."

François de Lino died in 1721 and was buried in the church in Quebec. His widow remarried. Her 
children from her marriage with de Lino were: Marie Angelique, Ignace François Pierre and Louis Xavier, de Lino de Chalmette, who was born and baptized in Quebec in 1720. He became an officer in the troops of the Marine and was commandant in the Arkansas country in 1751. He is mentioned by Michel de la Rouvillière, the commissary under Vaudreuil, in an official communication as "M. de Lino, Lieutenant, a relative of M. de Vaudreuil," who had left his post without permission and had come to New Orleans, but who was sent back at once by M. de Vaudreuil who, however, did not inflict any punishment upon him, "because there is no discipline here." He married, in New Orleans, Madeleine Marguerite Broutin, daughter of Ignace François Broutin, a Captain of Engineers in Louisiana and commandant of the post at Natchez. Her mother was Marie Madeleine Lemaire, the widow of Philippe de Marigny. When Louis Xavier de Lino died in 1755 his widow married, the following year, Pierre Denis de la Ronde, a Chevalier of the Order of St. Louis, and son of Louise Chartier de Lotbinière. From this marriage there issued Louise de la Ronde, who married Don Andres Almonaster, and Pierre Denis de la Ronde, who married Eulalie Guerbois.

Madeleine Josephine de Lino de Chalmette, the daughter of Louis Xavier de Lino and Madeleine Broutin, born in New Orleans in 1752. She was married, in 1777, to François de Verges de St. Sauveur, a retired officer, the son of Bernard de Verges, Chevalier of St. Louis and of Dame Marie Therése Pinot. She died in New Orleans in 1722. Louis Xavier de Lino de Chalmette, son of Louis 
Xavier de Lino and Madeleine Broutin, born in 1753, married in New Orleans Adelaide Fazende, the daughter of Gabriel Fazende and Charlotte de Verges. Ignace de Lino de Chalmette, on whose plantation the Battle of New Orleans was fought, was the posthumous son of Louis Xavier de Lino and Madeleine Broutin. He married Victoire de Vaugines, daughter of the Marquis Etienne de Vaugines, Lieutenant-Colonel in a regiment of the line and a Chevalier of St. Louis and of Dame Antoinette Pélagie Petit de Livilliers. He died in 1815; his widow in 1836.

Chalmette figures in de Pontalba's letters to his wife, it may be remembered, as returning from his post in the West with a large fortune which de Pontalba looked upon with suspicion until he found out that it was real and legitimately acquired. $\mathrm{He}$ came to New Orleans with a large family; among them two young lady daughters, Victoire and Azelie, very gay and charming, but needing the accomplishments to be acquired in the city.*

* A delicate note on miniature paper bordered with roses has carried down the past century the following gallant trite souvenir of Azelie when a young lady.

"To Mademoiselle Chalmet, at her Mother's,

Royal Street between Contti and Bienville:

"The Domino of yesterday evening presents his compliments to Melle. Azelie Chalmet, and begs her to have no feeling against him if he does not make himself known. Circumstances force him to this. Nevertheless, if she is going to the ball next Saturday, she will be teased again by a 'rabbit head,' who will be the same person as last night. It is useless for her to seek to know him by means of this note, for he has changed his handwriting.

"He wishes her all happiness, and will be the first to kiss her hand when she steps aboard Hymen's bark.

"Her devoted servant."

Kindness of the late J. W. Cruzat, who holds the original. 
Chalmette, looking for an investment for his money, was persuaded by Philippe de Marigny, his relative by marriage, to buy a plantation below the city, presumably the very plantation upon which the battle was fought. De Pontalba advised against the purchase and confided to his wife that he thought Philippe de Marigny was unloading on Chalmette an unprofitable piece of property; but this suspicion did not dawn upon the gallant Chalmette, although the plantation never proved a profitable investment.

When Marigny died he made Chalmette the guardian of his young son, Bernard, who, as he had found out, needed a strong hand to guide him. Chalmette's conscientious interpretation of this responsibility and his serious efforts to convert the monumental spendthrift of Louisiana (as he turned out to be) into a thrifty, sedate young gentleman have been detailed in the life of Bernard Marigny. Chalmette used to repeat to his pupil: "Get education-a man without education is only half a man."

Until he died, his life was that of an easy-tempered, pleasure-loving sugar planter, possessed of ample means to gratify his social tastes. In the Museum of the Historical Society in the Cabildo is shown a silver trophy won by Chalmette in a shooting contest in 1812, a "Papegai" (so named from the target, a gaily painted bird, perched on a post), one of the popular sports of the city. He was a noted shot and could hit a mark, firing back over his shoulder. In the same case with the trophy is a collection of pretty feminine trifles: black lace veils, fans and bits of jewelry, collected from the ladies of the family to whom they had descended; trinkets at which the eye smiles through tears. They had 
belonged to Madame Chalmette, and as pretty as her trinkets are, so is the praise of her husband, that although a man loving pleasure and the ladies, he never forgot his love for his wife.

When the British Army made its appearance below the city, the Chalmettes abandoned their home and sought shelter in a small house on Royal Street between Conti and Bienville Streets, a little house that they kept in the city as a "pied a terre" when in town attending the opera or balls. One week after the battle, Chalmette mounted his horse and rode to his plantation. Nothing remained of his home but blackened ruins. Even the oak trees that surrounded the house were annihilated. It is said in the family that the rocket that set fire to the house and buildings to destroy them, for military reasons, by Jackson's orders, was sent off by a young man of the connection. To make his ruin the more complete, Chalmette had just bought the plantation adjoining his intending to cultivate it. Without hope of ever retrieving his fortune, he turned his horse homeward. Three weeks after the battle, two weeks after his visit to the scene of it, he died, and was buried in the St. Louis Cemetery. 


\section{CHAPTER XXII}

\section{CRUZAT}

TRACING a good family to its genealogical 1 source is like following a path up a mountain to its summit-sure of the prospect to be enjoyed.

Fray Garcia de Engui, * in his manuscript history of Navarre, affirms that the family of Cruzat is one of the most ancient and illustrious of that kingdom; and Lope de Vega, in his "Conquest of Jerusalem," makes mention of Don Pedro Cruzat fighting with Don Ramire, King of Navarre, and Godefroi de Bouileon when the holy city was captured. He gained great fame for himself, which he extended by his further exploits on the Euxine Sea and the Indian Ocean.

A worthy descendant of Don Pedro was Don Aymar de Cruzat who, in the thirteenth century, acquired lordship over many cities of Navarre. With noble and knightly valor, he defended Pampeluna against the Navarrese, receiving an arrow wound in the face, for which he was rewarded by King Philip in the year 1279.

$\mathrm{He}$ had married Madeleine de Marigny, of a noble French family. His one son, Raoul Cruzat, married his first cousin, Blanche Almoravid, daughter

* Taken, with the kind permission of Mrs. J. W. Cruzat, from the compilation made by her late husband from the authentic documents in the family archives of the Marquis de Feria, all of which have been legally attested. 
of Garcia Almoravid and Violante Marigny, in an effort to unite the rival houses of Cruzat and Almoravid and stay their bloody encounters. Their sons, Berenger I, II, and III, maintained the fame of the family as fighters and, during the following century, the family rose to important positions in Spain, enjoying the steady favor of the King, who conferred on them the highest decorations of chivalry and accorded the family the privilege of representing the nobility of Navarre and voting in the Cortes.

By the end of the fifteenth century the elder branch became extinct and the name of Cruzat was merged into that of Gongorra, the name of the marquisat conferred on Jean Cruzat in 1695. To the elder branch belong Don Luis, who became Grand Prior to the Order of St. Iago; Michel, a General in the Spanish Army and a Knight of Calatrava, who died in Havana fighting against the Dutch; and Fray Martin, Grand Master of St. Iago, who was Governor of Galicia and Viceroy of Sicily. The younger branch of the family, known as Espeleta, gave to Louisiana the family known in New Orleans to-day.

Francisco Cruzat, the first of the name in Louisiana and the son of Balthasar, was born in Tafala, Spain, in 1739. He became a Captain of Grenadiers and came to Louisiana in the troops of O'Reilly. Unzaga, the first Spanish Governor after O'Reilly, appointed him to be Lieutenant-Governor of Upper Louisiana (the Illinois country), in 1780. He was promoted to Lieutenant-Colonel by Calvez for services rendered in his campaign against the English, and reappointed to the position of Lieutenant-Governor of 
Upper Louisiana, one of the most important positions in the Spanish colony in the critical period of its history when French, English and Indians were all intriguing against it.

Cruzat married a countrywoman, Nicanora Ramos $\mathrm{y}$ Tibaldo of Cartagena, Spain. Their home was in St. Louis. She was the heroine of an adventure that made a commotion in the Spanish colony and came near bringing on active hostilities between the British and Spaniards. With her two little sons, she was making the return voyage from New Orleans to St. Louis (to join her husband after a visit to the city) when her boat was attacked at the St. Francis River. According to the report she made of the occurrence, as her boat was passing they were hailed in French by a man who told them that he had letters from Don Francisco Cruzat for his wife. Believing this deceitful pretext, her captain ordered the boat to be stopped so as to get the letters. As soon as they were near the strange boat a rope was fastened to them and they were summoned to surrender as prisoners of the King of Great Britain. About the same time there came rushing out of the bushes about forty Englishmen, who took possession of the boat and tied the passengers and rowers. While they were tying the rest, Jayme Colbert, a Frenchman in command of the Englishmen, claimed her. He told her to be calm, that she would not receive the slightest offense and that he would conduct her in safety to her husband in Illinois. He had the boat brought alongside and all entered it. When they had gone about a quarter of a league the boat was stopped and all were taken to a prison made of logs, with no opening except a 
wicket gate and a hole on top for air. She was well treated in prison. Finally, a few days later, the alarm came that some pirogues of Americans were approaching. Colbert took away the other prisoners, leaving her alone, and telling her to keep her sons quiet. He returned soon to put her and her sons on their boat. She told him that she knew nothing of the region and asked that the owner of the boat be released from prison. This was done. They went on foot through a thick wood of sassafras and after having crossed rivulets and brooks arrived at the place where a boat was moored. She did not know how far she was from the Indian (Chickasaw) village, but heard it was about eight days' journey. A Chickasaw chief (a son of Colbert), advised her to ask to be sent to New Orleans instead of to the Illinois Post. After many entreaties, her captors were induced to ransom her for the sum of four hundred pesos. She said the intention of Colbert had been to hold her in the Chickasaw region until they were exchanged for the Englishmen captured at Natchez. She died and was buried in St. Louis in 1796. Her husband, promoted to a command in the Regiment of Louisiana, came to New Orleans in 1788 and from thence went to Pensacola with his battalion and there he died. Their son, Joseph Cruzat y Ramos, served as captain in the Louisiana Regiment. He married Doña Maria Palao and died in Havana. Of his four children, all but one married. Joseph, his son, married Alix Coulon de Villiers, the daughter of Marc Coulon de Villiers, who was the son of the great Villiers, as Louisianians call him for the distinction he won in his celebrated encounter with Washington in 1756. One daughter, Eulalie, 
married Pedro Sedano. Their son became the first Count of Casa Sedano. He became also a Councillor of State, Deputy in the Cortes, and Gentleman-in-Waiting to the King. He wore the Grand Cross of Isabella the Catholic, was a Chevalier of the Order of Carlos III, was given the Grand Cross of Medjidie and was made Commander of the Legion of Honor of France. He was also a member of many literary and artistic societies and became associated with Castillo in the Liberal government of Spain. The other daughter, Malvina, married Nicolas Heredia, an officer of Public Instruction and Professor of Literature in the University of Havana.

To descend to the plainer and simpler folk of our New Orleans narrative, Antoine Cruzat, the son of the Governor of Illinois and Nicanora Ramos, was born in St. Louis and came to New Orleans in 1795. In the same year he entered the service of Spain as cadet in the Regiment of Louisiana, continuing in this service until the cession of the colony to the United States. He then retired from military service with the rank of Captain.

He had married, in 1796, Victoire de Lino de Chalmette, or, according to the Spanish record of it, Victoria Morenciano de Chalmette. His marriage was a long and happy one, being blessed with fifteen children. He was staid and dignified; his wife sparkling with fun and wit. Many amusing stories are related of them. She was devoted to balls and never missed one; he was too serious to care for them. One night after she was dressed in full ball costume, with her hair piled up in puffs and curls, topped with a feather, awaiting the time to start, he felt a twinge of rheumatism and decided 
that he could not expose himself by going out. She protested. He was stolid. "To bed then," she said with a shrug of the shoulders and bundled him off to his couch. Dressed as she was, she covered herself up in hers. As she lay there, regretting the pleasure she had missed (he, well satisfied, went to sleep at once), she heard whispering and laughing outside her door and her name called. "Come to the ball! Come! Come! We cannot get along without you! Everybody is asking for you! It is not a ball without you!" And so they went on. She stood it as long as she could; then with a bound she was out of the bed. "I am coming! I am coming!" She shook out her skirts quickly. "Bonne nuit, Don Antonio; I hope your rheumatism will get better with sleep." She opened the door to the street. (It was one of the little houses of early New Orleans architecture.) "Ah, how good it was I did not take down my hair!" (putting her hands up to feel her puffs and feathers) was all she said to her friends.

When the colony became American, Antoine Cruzat became an American citizen, though he was the only one of the family to do so. His eldest son, Manuel, born in 1798, fought at the Battle of New Orleans and doubtless witnessed the destruction of his grandfather's home and plantation. He married Malvina de Verges, daughter of Pierre de Verges and Heloise Chalmette, and died in 1848. His children were Malvina, who married Denis Villeré, the son of Gabriel Villeré; and Odile, who married Edmond Villeré, brother-in-law of her sister. Each daughter left five children.

In 1814, Antoine Cruzat was chosen by the Police 


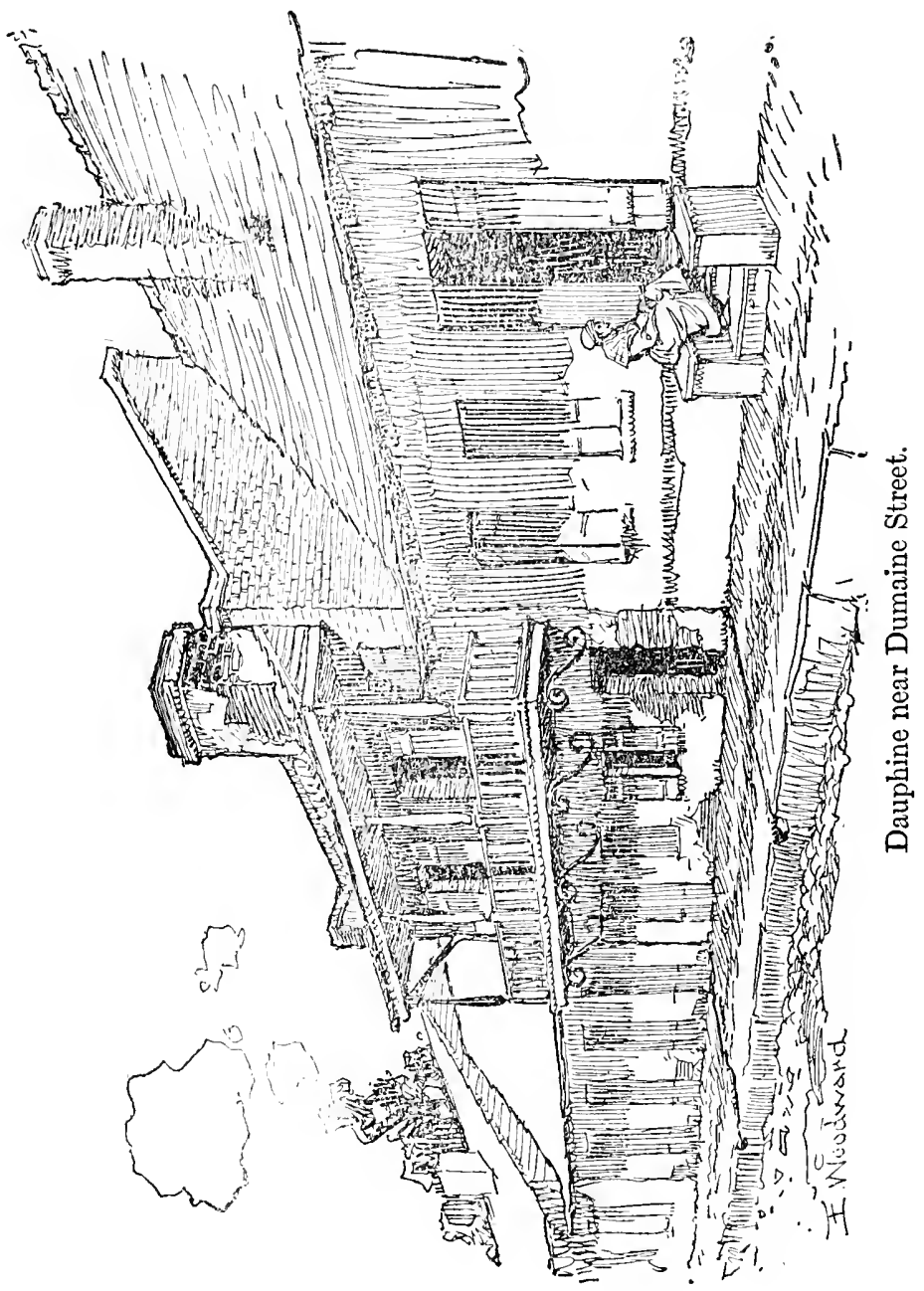



Jury of the Parish of Orleans as Treasurer of the Parish. He served also as Secretary of the Jury until it was abolished in 1848. For thirty years, also, he was Warden of the St. Louis Cathedral, a position of the highest local distinction and filled only by men of irreproachable reputation.

He died in New Orleans in 1854-a man of dignity and personal importance; of unquestioned honor and judgment; and an infallible authority on the events and men of the Spanish Domination to whom recourse was ever had when such information was needed. The long list of his children is as follows: Armand, Manuel, Nisida, Luisa, Ignace, Zoé, Laure, Victoire, Gustave, Celestine, Mathilde, Eulalie, William, Charles and Edmond (twins).

Nisida married, in 1819, Laurent Rousseau, the son of Pierre Rousseau, Captain in the United States Navy, later Commodore in the Navy of the Confederate States. Luisa married Gustave Laferanderie of St. Domingo. Zoé married Stanislas Nelson Peychaud, born in Kingston, Jamaica, but one of the youngest of Louisiana volunteers in the Battle of New Orleans. She was born in 1803 and lived until 1896. She was twelve years old at the Battle of New Orleans and up to the time she died loved to relate what she remembered of it and of the great men of that time. Like her mother and, indeed, like all her sisters, she was fond of society and shone in light conversation, consequently was very attractive to the old beaux who had the same taste as she. It is one of the pleasant recollections of her that, when she was past eighty, she would always be found of an afternoon in her salon, dressed with care, sitting in her armchair, awaiting the visitors, 
who never failed to make an appearance. Her maid Annette once asked what colored dress she would put on that afternoon: "Ah, bah! Pink, blue, green, yellow! What difference does it make? At eighty one can wear anything." And it is true, no matter what she wore, she was charming.

When she died she seemed to take away a part of the city with her. New Orleans has never been the same without her. She was the type of lady that made the society of the city delightful a century ago. The garden conditions were more favorable to such productions then than they are to-day and, like the fairies, such old ladies have passed away. Independence of spirit, sure-footed reliance on the stability of fortune, confidence in the divine right of women, made the charm which is lacking in our old ladies of to-day, born into a different world, at a different time, to play on different guitars.

Zoé's sister, Celestine, married also a Peychaud, but not of the same family. Amedée Peychaud, her husband, was born in St. Domingo of French parents. He and his sister, Lasthémie, were saved from massacre in the insurrection of the slaves by their nurse, but in the panic of the moment the children became separated and the boy was brought to New Orleans alone. As he grew to manhood he never ceased to long for his sister and to search for her. At last he heard that she was living in Paris; he sent for her and had her brought to New Orleans. As the ship came up the river he stood on the levee waiting for her. She was the first passenger to step on the plank and walk to the shore. As she did so, a gust of wind blew aside her skirts and revealed the most beautiful foot and ankle in the world-at 
least so thought a young man standing in the crowd to watch the ship arrive. He sought her acquaintance (gentlemen at that time acted on such impulses), found her face as beautiful as her foot, and then he sought her in marriage (as a gentleman of that time would do), and he did not seek in vain. Lasthémie became his wife and he, in time, became a distinguished Judge. She died after the birth of her only son, Charles Amedée, who was reared by his Aunt Zoé. He, to carry the story a generation further, married, in 1862, Marie Meffre Rouzan, the daughter of Julien Meffre Rouzan, the wealthy merchant and bon vivant of his day, and of Alice Olivier de Vezin. The Rouzan home on Esplanade Street was, in its day, the ne plus ultra of French luxury, and the entertainments in it were royal events in society.

Mathilde Cruzat married Dr. Edward B. Harris. Like her sister Zoé, she lived to a great old age, dying in her eighty-ninth year, vivacious and entertaining to the last. She outlived her three children, and her grandchildren, too, have all passed away. Eulalie, the last of the Cruzat daughters, who was born in 1817 and died in 1906, married Edouard Gardère in 1841. He was the son of François Gardère, Treasurer for the State of Louisiana, and of Elisa Rivière, the daughter of the brilliant Madame Rivière, who was the life of the social circle of Governor Carondelet. The Gardères lived on a great plantation opposite the city, which is still in their possession and where they, despite the cruel changes wrought by time to plantation owners, still maintain a kind of seigneurie over the region. The seclusion of their home and their own dignified 
sove of retirement have, as it were, sealed their family archives from the public.

The children of Edouard Gardère and Eulalie Cruzat are Louise, who married George Olivier; Arthur; Edouard; William; Corinne; Gustave; and Alice, who married, in 1889, William O'Connor.

William Cruzat, the thirteenth child of Don Antoine Cruzat and Victoire de Lino de Chalmette, was born in 1819, and died in 1900, attaining the good old age that seemed a hereditary right of the family. He married his cousin, Joséphine Olivia Cruzat, daughter of Joseph Ignace Cruzat, Spanish Consul at Mobile, and Alix Suzanne Coulon de Villiers. His long life was devoted, not to material but to historical interests.

He left one daughter, Modeste, and a son, John William, born in 1858, whose life, therefore, is still too fresh in memory for a review of it as history, and yet no man, in truth, ever served history better or more faithfully. Into his soul had been breathed, as it were, the breath of the finer life of the past of his State; and the inspiration elevated him above the sordid views of the present. To his fellow citizens he appeared, doubtless, merely a steady-going, hardworking bank official, with a brain intent only on its treadmill duties, whose handsome face was ever clouded with the shade of portentous responsibilities. To the eyes of a few friends, however, he revealed his real identity-that of a secret, ardent student of history, a passionate collector of documents and facts to serve, as he knew they would serve, to make the path straighter for other students and to build up reputations that would overshadow his own modest worth. He was a recluse, shy of outside 
intercourse, sparing of words, self-effacing to the utmost limit, yet outspoken and bold in historical interests.

A good friend of the Louisiana State Historical Society, he served as its treasurer in the hard years of its rehabilitation after its seeming final bankruptcy caused by the Civil War, taking upon himself a burden shunned of others. In his hands meager financial reports lost their depressing influence; and the members of the society were sustained by the sense of carrying on a noble work in the intellectual progress of the State. He drew upon the casket of his memory, in which were stored the historical relations of his father and grandfather, to supply papers needed for an evening's programme. What he wrote has been proved authoritative on the subject of the Spanish Domination, and the historical importance to the colony of the men contributed by Spain to its population. He generously opened, when they were needed for an exhibit by the society, his precious and unique store of family medals, medallions, miniatures and decorations, and placed them on riew. In short, as a member expressed it, "Cruzat was not only the treasurer but the treasure also of The Historical Society."

Ill health forced his retirement from the Bank but not from his good historical work. His correspondence during his last years with his relative, Baron de Pontalba of Paris, resulted in obtaining the invaluable collection of the Pontalba letters to which due honor has already been paid in this volume. He obtained also from the Baron the letters and secret despatches of Governor Miro that throw the light of day into a very obscure corner of 
international history-a collection of documents that interest not only Louisiana but the whole continent. His carefully traced genealogical records are and must remain the foundation of such research work. He died in 1913, leaving behind him his study, filled with books, notes and documents, a mass of material that is still to be properly inventoried, that can never be rightly appraised.

Cruzat married, in 1883, Héloise Hulse, the daughter of Albert Hulse (of an old Welsh family), and of Mathilde Chauvin de Lery (that sure and well-certified historical family). His wife proved an able coadjutor in his historical work and, since his death, the ardent executor of his rich historical estate. Their three children are: Joseph de Villiers, Marie Josephine (Mrs. James E. Strawbridge), and William.

Note.-Héloise Cruzat is at present Assistant Secretary of the Louisiana Historical Society and a most indefatigable worker for it. Her essays on Louisiana history and her translations from old Spanish and French documents place her in the first rank of present day historical writers. Like her husband, she learned three languages perfectly-English, French and Spanish. 


\section{CHAPTER XXIII}

\section{JUMONVILLE DE VILLIERS}

THIS name is considered a feather in the cap of 1 Louisiana, stuck there in honor of a celebrated episode that preceded the War for Independence which linked the name with that of Washington.

The incident is ancient now, but in its day of youth and freshness found a place in every American history. As it was then related: In 1753 the French and English in America were at péace by virtue of the treaty of Aix-la-Chapelle, but both sides were secretly on the alert for the renewal of hostilities which soon was to follow as the Seven Years' War. Their traders clashed over every boundary line and advanced post. The policy of France, as we know, was to unite Canada with Louisiana by means of a chain of fortified posts, which would insure her the possession of the great waterways of the country, and crowd England between the Alleghanies and the Atlantic Ocean.

Midway between Canada and Louisiana lay the Ohio Valley. Should the English gain possession of it, they would cut in two the French line of fortifications and sever the territory of Louisiana from the French. This the English were determined to do. They sent their men out from Virginia and established trading posts along the banks of the Ohio and its branches, and their traders were soon deftly winning the Indians to allies. The French, no whit 
behind the English in enterprise, descended through Lake Erie, drove the English away, and built three forts to guard their position. One of these, and the most important, was Fort Duquesne, situated at the fork of the Monongahela and Alleghany Rivers (the present site of Pittsburgh).

George Washington, then a young lieutenantcolonel in the Colonial army, was sent by the Governor of Virginia to make a protest to the French against their encroachments.

The protest proving unavailing, he was sent the following year with a military force against the new fort. He marched in advance of the troops at the head of a detachment to clear the way and make a road for the advance of the rest of the army.

While he was thus engaged, Indian spies and scouts brought him warning that a French force was advancing against him, hoping to surprise him. To prevent this, he advanced his troops, maneuvering to surprise the French. He succeeded. The French saw him in time only to rush to their arms. A spirited fight ensued, during which Jumonville de Villiers, the young commander of the French, "about the same age as Washington, was killed, after which his troops surrendered and were sent prisoners to Virginia.

When the news of the disaster reached the French in Louisiana, passions flamed up in wild fury, with clamoring for vengeance against the English. Coulon de Villiers, a brother of Jumonville, stationed in the Illinois country, obtained permission from Governor Kerlerec to leave his post and proceed at once to avenge his brother's death and wipe out the disgrace to French arms. For this purpose he raised a 
force of five hundred Frenchmen to which were added several hundred Indians. He hastened to Fort Duquesne and found Washington entrenched in a rude fortification called Fort Necessity, not far from the scene of his first engagement. Coulon de Villiers and his Canadians attacked with such fire that the English soon showed signs of yielding and agreed to a capitulation. Washington, who did not understand French, was obliged to use an interpreter, a man of great ignorance and, as it turned out, untrustworthy. Coulon's terms contained a clause whereby Washington acknowledged that Jumonville de Villiers had been assassinated by the British, who fired upon him without warning when he was, as the French claimed, merely a peaceful envoy to the British. The word "assassination" had by the ignorant interpreter been rendered "killed" in the articles that Washington signed, as was fully explained afterward. However, the surrender of the British took place to Coulon de Villiers on the 4th of July, 1754, and the Father of his country had to withdraw before him!

The incident created a reverberating excitement in France, and the vile epithet of assassin was hurled at Washington in all public assemblies and speeches, and as such he was denounced in all the newspapers and journals. Thomas, a distinguished member of the Academy, wrote an epic in four cantos entitled "Jumonville," expressing the utmost violence of abhorrence for the dastardly way in which he had been assassinated.

Coulon de Villiers won a promotion for his victory and was made Chevalier of the Order of St. Louis. On the surrender of Canada to the English, he with 
his two sons came to Louisiana and settled in the Opelousas country. The eldest son was in the service of Spain when the cession to the United States took place. He took the title of chevalier after the death of his father, and died in Opelousas, leaving a large family whose descendants write their name to-day Devilliers.

The second son, Coulon, likewise served in the Spanish Army, and after the cession went to Havana to live, and he died there.

The "old chevalier," as he was affectionately called, married a second time, uniting himself in New Orleans with Marie Françoise Beaumont de Livaudais. He lived to an advanced age, dying in New Orleans in 1803 . The only child by his second marriage, Charles, became a planter; he married Marie Louise d'Acosta, and died in the parish of St. Bernard in 1833. He was buried in the old St. Louis Cemetery, where may be read the epitaph on his tomb:

\section{"Ci-git}

Charles Jumonville Coulon de Villiers, Rejeton d'une illustre race

Sans cesse aux coups du sort opposant son grand cœur

Dans l'etroit sentier de l'honneur,

De ses ayeux toujours il a suivi les traces."

During the British invasion in 1814, some of his property was expropriated by General Jackson for the public defense, and his fortune was thereby considerably damaged; in token of which may be cited the following anecdote, one of the best known in the repertory of the rare raconteurs of the time.

Some years after the event, Bernard Marigny introduced a bill in the legislature for the relief of 
Charles Jumonville de Villiers, and in the course of an eloquent speech gave the French version of the death of the Sieur Jumonville de Villiers, and was understood to hint that France and the French had first made Washington a hero.

Larry Moore, the well-known senator from St. Helena, shouted in a voice of thunder: "Not a word of truth in it! Not a word of truth in it! God Almighty made George Washington a hero!"

The Senate was thrown into confusion. Marigny looked daggers. Old Larry frowned defiance. Marigny glowed with the blood of his chivalrous race. Moore was the type of a frontiersman: shrewd, prompt, brave as a gamecock. Friends interposed; explanations ensued; neither gentleman understood perfectly the language used by the other. Marigny had been too strongly construed. Larry meant not a personal, but a historic, lie.

Enthusiasts have sought to connect the family of the de Villiers with the one from which sprang the celebrated Duke of Buckingham; but the family in Louisiana seems to cherish no such claim, looking to no higher or better source of origin than Nicolas Antoine, Sieur de Villiers, a captain in the army of Canada and his good wife Angélique Jarret de Verchères, who was the granddaughter of the Baron de Longueil, and therefore a Lemoyne; hence a cousin of Bienville. She bore her husband seven sons; all of them served in the army of France.

Aubert de Gaspé, in his fascinating volume, "Les Anciens Canadiens,"* gives a tradition of the "Dames de Verchères," which is also current in the Louisiana family; that in 1690, being attacked by

*Published in Quebec, 1864. 
Indians in a fort, when all the men were absent, they put on men's clothes and, seizing guns, marched around the fort beating a drum so loud and lustily that the Indians were deluded into the belief that a strong garrison was inside and retired.

De Gaspé's grandmother was a Jarret de Verchères, and as the grandnephew of Coulon de Villiers, he gives the family account of the Fort Necescity surrender which accentuates the bad faith of Washington, but he adds frankly that Guizot, after examining all the proof furnished by the French, put no credence in their version but adhered firmly to the truth of Washington's report of the affair.

Gayarré, in an article on the surrender of Fort Necessity, published in the Magazine of American History, gives a print of a portrait of Coulon de Villiers. He is represented with a face of noble beauty and expression; of manly strength and firmness, tempered with courtesy and gentleness. 


\section{CHAPTER XXIV}

\section{LAVILLEBEUVRE}

\section{JEAN LOUIS FIDEL FARAULT DE LAVIL-}

LEBEUVRE, Chevalier de Garrois, lives in the annals of Louisiana history as one of the most eminent of public officials under the Spanish Domination. He served as Indian Agent, or, as we would call it to-day, Commissioner, from 1780 to 1797.

Lavillebeuvre was born in Rennes, the capital of Basse Bretagne, in 1731, and was the son of Baron Louis François de Lavillebeuvre and Dame Jeanne de Beaumont. About 1754, he came to Louisiana to join his uncle, Baron de Kerlerec, who was at that time Governor of Louisiana, his father having been induced by the Baron to grant the young man permission to come to the colony. Here he was commissioned Ensign of Infantry by Louis XV in 1762, and the following year a letter of commendation was written to him for his good services to France, by order of the King.*

In New Orleans, in 1764, he married Demoiselle Jeanne d'Arby, daughter of Jonathas d'Arby, an officer of Militia, the wedding taking place upon the d'Arby plantation near the city.

The transfer of the colony to Spain being effected, de Lavillebeuvre passed from the services of France to those of the new government; and as Don Juan

* Originals of commission and letter in the possession of Mrs. Anna Lavillebeuvre Hyman, of New Orleans. 
de Lavillebeuvre he was commissioned as Captain in the Louisiana Regiment of Infantry by Spain and was placed in command of Fort Panmure, one of the Natchez forts captured recently by Galvez from the British. Ricciardi, the only historical student, so far, who has made a special study of de Lavillebeuvre's services in the Louisiana colony, complains very justly that although he lived in a very critical period in the history of the colony, and rendered services unique in their value and scope, there is no mention of him in any of the histories of Louisiana, with the exception of the one written by Professor Alcée Fortier of Tulane University. Ricciardi, himself, has handsomely atoned for this sin of omission in others by his own diligent researches, delving for his information into the mines of the American State papers and sifting the Carondelet documents.*

The Baron de Carondelet, by order of the King, commissioned Don Juan de Lavillebeuvre to reside in the Choctaw Nation, whence the interesting letter of 1792, quoted by Ricciardi, is dated, giving an account of an assembly that Lavillebeuvre had held of that Nation, and of the speech he had made urging them to unite with the Chickasaws, Talapouches and Cherokees, to prevent "other white men (English, French and Americans) from seizing their land."

As Ricciardi says, the Indian trade was what both the Spaniards and Americans sought. In their competition to obtain its monopoly they made use of any intrigue or stratagem that cupidity could suggest-the favorite and easiest being to seduce * "The Services of Jean Louis Fidel Farault de Lavillebeuvre de Garrois." Nicholas A. Ricciardi. May, 1908. 
the Indian chiefs from their loyalty to sworn agreements. This was done, of course, by bribery in giving medals, gifts or assistance in their intertribal wars. The traders who were commissioned by the hostile outposts were unscrupulous agitators, who had no interest to serve but their private gain.

De Levillebeuvre lived in this hard command for five years, stolidly and faithfully serving his government, but maintaining, in what later generations have learned to know as the Lavillebeuvre way, his own honest principles, and not sacrificing them, as his predecessors had but too often done, to expediency. This is most apparent in his official letters and in the letters of others about him. He writes with dignity and courtesy of the great Indian chiefs with whom he was thrown in contact and gives what is strikingly absent from the letters of other Indian Commissioners, due consideration to their problems and difficulties, as well as to those of Spain. The acute condition arising from the marauding bands of vagrant Indians, deserters from their tribes, roaming the country, led for the most part by white men of bad character, in search of opportunities to commit depredations, producing friction among the tribes and arousing retaliating vengeance from the white inhabitants.

Carondelet, on his part, writes to de Lavillebeuvre with the utmost frankness, expressing full confidence in his capacity to bring about an intelligent settlement of the question upon which, in truth, depended the stability of the Spanish Domination over the colony. And de Lavillebeuvre was in fact reaching the consummation so much desired by the Governor; peace among the tribes and their submission to 
Spain, when, his health failing, he asked permission to go to Pensacola for medical treatment. Unfortunately he died on the way, at Mobile, in 1797.

His son Juan, who had married Mademoiselle Eulalie de Trepagner, survived him to pass with the colony back into the possession of France, and from France to the American Government. He fought in the Battle of New Orleans, in token of which his sword is still preserved by his descendants, although the record of his rank in the army has not been so carefully preserved.

But a little story is transmitted that is evidently considered of more importance. The day after he had bidden good-by to his wife and little son, with what apprehension only the young husbands of that date can appreciate, he went into camp. When the next morn had dawned on the desolate household, and none but the young wives of that date can appreciate what the desolation was, his little son Elie was discovered to be missing. For a few hours, the English, General Jackson, the absent husband, all were forgotten in the household, while a frantic search was made for little Elie. He could not be found and despair-the black despair of a mother who fears the worst for a child, settled down upon the once happy home. At last came a shout after an interval of anguish that seemed an eternity. The child had been found! Had been picked up trudging on his little legs determinedly down the highroad along the bank of the river toward the camp at Chalmette, going, like his father, to take part in the battle. He was at the time only five, some say four years old, and according to one version he was, when found, actually stumbling into the trenches. 
Little Elie lived to be an old man, but he never denied that he had run away to the battle.

Jean (as Juan was now called) Ursin had the reputation, in his day, of being a great hunter and a great lover of what used to be called fine living. He lived in the country above New Orleans, on a vast tract of land that stretched from the river across St. Charles Street to the woods bordering the lake. It is now called Rosa Park-a spot of exceptional beauty and much sought after by seekers of residential sites who love the, as the French call it, "je ne sais quoi," quality that gives it distinction above other similar sections. The distinction is a heritage from its original owner who has endowed it with the charming tradition that he gave entertainments in his handsome home to every man of note who visited New Orleans in his day. The portrait of his grandfather, the Indian Commissioner, in Spanish uniform, hung in the place of honor in the dining-room, and under it was the glorious sword of Chalmette.

Lafayette dined in this room in 1825. The mahogany dining table, like the glorious sword, can be still shown in evidence-a real mahogany table with leaves to match that could be extended to accommodate fifty places (and it did accommodate them for the Lafayette dinner). With the table can be seen the tablecloth that covered it of fine linen damask, like satin, such as could not be found to-day, with the fifty napkins to match, as large themselves as small tablecloths, woven according to a pretty fancy with a corbeille of flowers in the center surrounded by a garland of flowers. They were well worthy a festal board set in honor of so great a hero 
as Lafayette! Tradition, that seldom keeps within bounds when it is set talking, says that Chateaubriand was also entertained here by Lavillebeuvre, but, unfortunately for Chateaubriand, this is manifestly impossible.

The great hunter was evidently a great lover of beautiful things, and a generous spender of money to procure them, for he left behind him a trail of relics to beautify the homes of his descendants. His daily table service was of silver according to the fashion of the rich men of his day. His crystal and silver epergne, with candelabra to match, silver dolphins supporting the crystal (also used at the Lafayette dinner), are still the handsomest of their kind in the city, which is celebrated for such bric-àbrac. A mammoth silver salver, that in old times was filled on fête days and anniversaries with cornucopias of bonbons for all the children of the family and all their friends, is still kept waiting in refuge in the house of a great-granddaughter, for the day when it will once again be refilled. Near it is the old carved mahogany mantelpiece that stood over the fireplace in the home of Jean Ursin-and still doing duty as a timepiece is the tall mahoganycased clock that ticked the births and deaths during two centuries of the Lavillebeuvre family. There, too, is the round, gilt-framed convex mirror that, for all we know, may have once reflected the proud features of the great Lafayette.

The old father, son of the Indian Commissioner, had lived with his son Ursin through all the years that led from the cession of the colony to the Civil War, and through the Civil War into the ruin and sorrow beyond. At eighty-five his eye- 
sight was unimpaired, and his wits, for he was ever a witty and refined "joker." His devoted companion (a quaint memory) was a goose who followed him about all day, and slept at his door at night. He died in 1863, four generations following him to the grave. His old servants remained faithful to him; Françoise the cook, cooked his last dinner, for she had persisted in remaining a cook even after her husband attained the dignity of State Senator.

Elie Lavillebeuvre, the son of Jean Ursin, married Mademoiselle Jeanne Roman, the daughter of Governor Roman. After the death of his father he returned to the old square of the city and lived on Dumaine Street between Bourbon and Royal Streets, in a house that was always cited as a typical Creole home, with a handsome courtyard and great drawingrooms on the second floor, with Louis XVI furniture. Here were given from time to time receptions that united the best society from the old and the American population, Elie Lavillebeuvre and his wife always receiving the guests and presiding over the dances.

The name is extinct. Charles, the only son of Elie, died without children. Of his two daughters, one, Anna, married Thomas McCabe Hyman, son of a late Judge of the Supreme Court of Louisiana; the other, Ida, is married to Monsieur Lezin Becnel. 


\section{CHAPTER XXV}

\section{GRIMA}

THERE is no name more at home, so to speak, in 1 the city of New Orleans than that of Grima. The first bearer of it in Louisiana was François Albert Xavier Grima who came into the colony about 1780 , bearing, if the crudity of the expression be permitted, his patents of nobility not with him but in him.

Albert was the son of Jean Marie Grima, from the Island of Malta, and nothing, practically, is known of his history there. He enters Louisiana history through his marriage with Marie Anne Filiosa, daughter of Sylvain Filiosa, the hero of one of its pretty stories.

A gentleman of Paris, Sylvain Filiosa, came into the colony as a soldier in a troop of French cavalry, which was stationed at the Natchez settlement, and was there in 1727 at the time of the celebrated massacre of the French by the Indians. The massacre was so well plotted and carried out that the surprise of the French was complete, and their defense useless against the great horde of savages that had been assembled against them. Filiosa, with his troop, was cut off and surrounded; and their annihilation seemed inevitable when he, on the inspiration of the moment, seized a pair of cymbals and, jumping on his horse, beat them; leading a charge against the howling, blood-drunken, attacking pack. In fact, he played upon the cymbals so masterfully, 
that the Indians stopped short to gaze, fearfully, terrified at the new weapon used against them. *

The savages retired in dismay and thus the command was saved by "le fort Timballier," or "le beau Timballier," or "le vaillant Timballier," as he is called in the various accounts of the affair. Louis $\mathrm{XV}$, to whom it was reported, with his ready politeness always spoke of Filiosa as "Le Sieur Timballier."

The Frenchmen were all slaughtered, but the women and children were captured alive, to be reserved for worse torture and slavery. The family of the Sieur de Foucault were destroyed, with the exception of one young girl who one would like to think was saved by "le beau Timballier," but truth compels the admission that she was rescued by that middle-aged pioneer, Le Sueur, who, as we know, at the first cry of alarm from the Natchez settlement, hastened to the relief of the French with a great force of Choctaws, and he it was who delivered the captive women and children from the hands of the Indians, and took them to New Orleans. There the orphan children and the young girls were received by the good-hearted Ursuline nuns and given a home in their convent. Marie Anne Foucault lived with them and was educated by them, until she was given in marriage to Sylvain Filiosa.

Later in life, "le Beau Timballier" followed the peaceful avocation of farming on one of the islands of the Gulf of Mexico lying about the mouth of the

* From the family notes kindly furnished by Alfred Grima, Esq.; grandson of Felix Grima. The dictionary gives Kettledrum as the proper translation of "timballe" and Filiosa may have used a kettledrum, which would have been just effective against the Indians. 
Mississippi. According to tradition, it was given to him by the French Government in concession. All that is certain is that he lived there and that the island is still called Timballier after him.

In 1785, Albert Grima bought the corner of Toulouse and Bourbon Streets, a part of the ground upon which the French Opera House stood until it was burned recently. In 1795, he bought the adjoining lot on Toulouse Street, where the family lived until about 1840, when Felix Grima purchased the house on St. Louis Street. For three generations that has been the home of the family.

Albert had two sons: Bartolomeo, who settled in Mexico; and Felix, who remained to found the New Orleans family. Felix was born in New Orleans in 1798. He was taught, as was Gayarré a few years later, in the school kept by Lefort, whom Gayarré has rescued from oblivion in the reminiscences of his childhood. Like Gayarré, his great contemporary, Grima attended the Collège d'Orléans, then in its brilliant first days. He studied law in the office of the great jurist of the old Louisiana Bar, Etienne Mazureau, and was admitted to the Bar in 1819. Mazureau, who was Attorney-General, appointed him Deputy Attorney-General; and, in 1828, he was commissioned by Governor Henry Johnson, Judge of the Criminal Court of New Orleans. He married, in 1831, Adélaide Montégut, the daughter of Joseph Montégut "fils" and Gabrielle Rose Nicolas de St. Céran, a member of one of the fine old St. Domingo families, who, to the enormous benefit of the city, emigrated thence to New Orleans during the Revolution. Her father was a Judge at Port au Prince on the island: her mother, Geneviève de Linois, belonged 
to a Breton family, which gave several captains and one admiral to the French Navy. She was married to Montégut "fils" in 1805, on the same day and at the same ceremony which united her first cousin, the beautiful Madame Moreau, to the great lawyer and patriot, Edward Livingston.

Montégut, who was at one time an officer in the Spanish service, became afterwards a planter and died quite young in 1815. Montégut "père" was a native of Rocos Armagnac, France, and was the son of Raymond de Montégut. He came to Louisiana about 1760, and after the Spanish transfer became an intimate friend of Galvez. He was the chief surgeon of the Charity Hospital as early as 1775; and in 1800, under Claiborne's administration, became Secretary of the Treasury of Louisiana. His wife was Françoise de Lille Dupart, the granddaughter of Pierre de Lille Dupart, who owned a great concession on the outskirts of New Orleans. One of the ancestral Duparts was burned at the stake by the Indians during the Natchez war. Pierre de Lille Dupart left liberal bequests to the Charity Hospital in his will, which is still extant, dated 1775.

One of the daughters of Montégut "père," Solidelle, married Joseph de Roffignac, son of the famous Mayor of New Orleans; another daughter of de Lille Dupart married Mandeville de Marigny; a third married Don Bartoloméo MacNamara; a fourth, Don Juan Arnoult. Her father dying young, Françoise de Lille Dupart was reared by her aunt, Madame Mandeville de Marigny. A very interesting painting, in the Museum of the Historical 
Society at the Cabildo, represents Dr. Montégut and his family, including Madame de Marigny.

Grima's learning, ability and conscientious work procured for him influential clients and he became attorney for numerous prominent banks and business firms. He was in full course of a lucrative professional career when the Civil War, like a cataclysm, overturned the peace and prosperity of the country. His devotion to the State and to the principles of secession exposed him to the rigors of General Butler's administration, and he was menaced with expulsion from the city, but he was saved by the influence of a devoted friend in the opposite political camp.

This influence, however, was unsuccessful under General Banks, the successor of General Butler; and Grima was banished on a twenty-four hours' notice. He went with his family to Augusta, Georgia, and maintained himself during his exile by teaching school and giving private lessons. In 1865, he returned to his home and from the ruins of his profession established anew his practice which netted him again a large fortune.

He was a sound scholar, a linguist and a lover of good literature-and from time to time he made contributions to the French publications of the city, one of which, "Les Souvenirs d'un Exile" is still cited with interest and pleasure by lovers of native Louisiana literature. He was noted for his social relations with his professional brethren, particularly for his long friendship and intimacy with François Xavier Martin, the great Chief Justice of Louisiana. The chaste and imposing monument erected over Martin in the St. Louis Cemetery No. 2 (on Claiborne Street) was made from the design selected by 
Grima. The Grima house on St. Louis Street is forlorn now in its old aristocratic neighborhood; its neighbors have deserted it, forced to retreat before the contaminating advance of lower society. The fine old street with its saintly and kingly name is, sad to say, retrograding into a decadent quarter, but the house stands like a dowager of the old nobility, dignified and self-possessed in her handsome middle age, before the encroachments of undesirable intruders. The most careless passer-by could hardly fail to notice and admire it, a typical sample of architecture produced by the blending of French and Spanish taste. The windows are wide, the front door is surmounted by an elliptical arch with fanlights, with slender columns on each side. It opens with a generous sweep into a great hall that runs the length of the house. From the hall rises majestically a stately, curving stairway, whose newel posts are of brass. On each side of the hall are the four great gala rooms, de rigueur in colonial days, with walls frescoed on canvas-where, so the memory of it runs, were given the most beautiful balls of their day in the city; and beautiful they must have been to be worthy of their setting. To one side is the garden, as broad as the front of the house-so sheltered behind a tall brick wall that from the outside only the tops of trees and shrubbery are visible; but on the inside filled with pretty conceits, walks and parterres, where still grow the bright, variegated, old-fashioned flowers of a half century ago. It is the kind of garden that used to be planted and tencled by the knowing hands of an old slave gardener under the eye of a flower-loving mistress.

For the first time in eighty years the noble old 
house is empty and deserted; its hospitable rooms as useless as withered breasts. Its young families moved away from it. The "Silent Chariot" bore away others. The last of its daughters, Adelaide, was carried out of the old portals only a few months ago to a last station in the Cathedral, and then to her last resting place in the cemetery. She was charming and well beloved, the very incarnation of the grace and spirit of old New Orleans. Heaven had endowed her with its choice blessing, a beautiful voice, that ministered to the delight of society. But while it was still fresh and in its full beauty, she withdrew it from the world and consecrated it to the service of the church-to gaunt old bare St. Augustin. It is pleasant to remember that the poorest and not the richest church, the humblest and not the proudest congregation in the city was chosen by Adelaide.

Sweet singer, dear friend, Requiescat in Pace. 


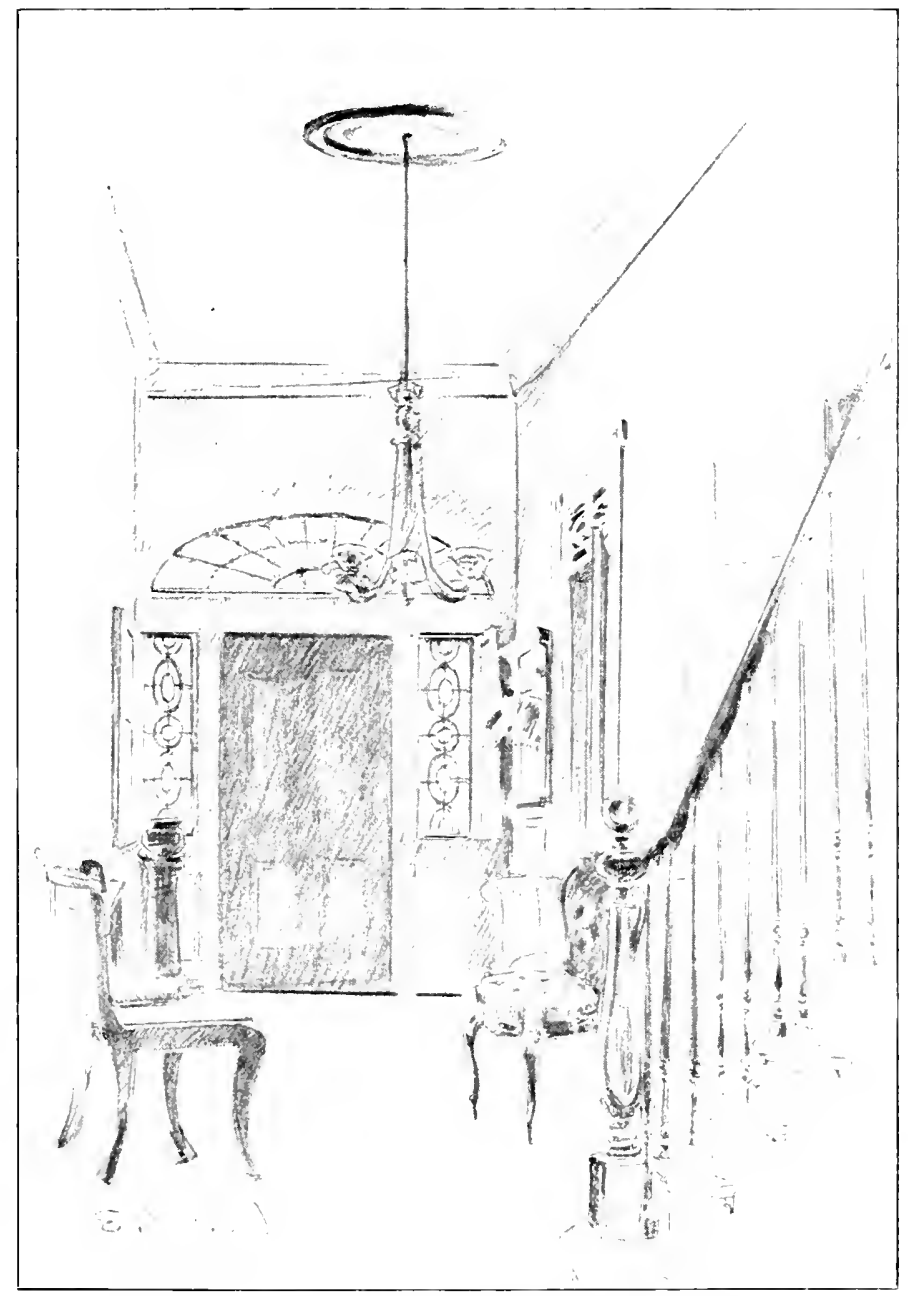

Vestibule of (irma House- Newel Posts of Brass, Balustrade of Mahogany. 


\section{CHAPTER XXVI}

\section{FORSTALL}

THE Forstalls lie like a stratum of rich ore under 1 the soil of New Orleans society. Scratch the surface under any prominent name, and you tap a Forstall. The vein is pure and true, and it has yielded in the past a good profit to the city.

The record* of the family leads back, not to France, but to England, the name being originally Forestier, Forster, Forestall. A William de Forestier, a Norman knight, crossed the Channel with William the Conqueror in 1066. Among the great Anglo-Norman families which became established in Ireland in the twelfth century was that of Forestier, or Forestall, which possessed a great estate in Kilkenny. The first of the name in Ireland was Lawrence le Forestier, one of the companions of "Strongbow," Earl of Pembroke, when he invaded the country in 1169. According to the register in

* Taken from the papers kindly loaned by Rathbone de Buys, Esq. The documents and the genealogical record that accompanies them, proving the descent of the family as narrated, are attested "as in every respect true and genuine by the Archbishop and Primate of Ireland, the Archbishop of Juam, the Bishop of Waterford and Lismore, the Bishop of Cloin and Ross, in Dublin, October 12th, 1758." The attestation is further guaranteed by the Apostolick Prothonotary, who certifies that "the antecedent lodges and arms of the Forstalls are true and genuine, as recited in the antecedent Genealogy: Signed by Fr. Thomas de Burgos, doctor in divinity and prothonotary Apostoiick. 9th of November. 1758." 
the office of Ulster King of Arms in Dublin Castle, the Forstalls of Louisiana descend from Peter Forstall, Esq., one of the descendants of this Lawrence, and are entitled to the same armorial devices-the three broad arrowheads on a shield.

Peter Forstall, whose will was proved in 1683, married Mary, daughter of Nicholas Aylward, Esq., of Shankill. He left several children. His eldest son was Edmond Forstall (the name so well known in New Orleans), who married Eleanor Butler of Dangan, of the noble house of Ormond. All of his three sons became Knights of Jerusalem.

Edmond Forstall entered the military service of France and became Captain of Dragoons under Louis XIV. He married, in Ireland, Elizabeth, daughter of Henry Mead, Esq., of Kilkenny. Their eldest son, Nicholas, emigrated from France to Martinique, taking up his residence in the town of St. Pierre, where he married, in 1725, Jane, daughter of John Barry, K.C. Their eldest son, Michel Edmond Forstall, born in Martinique in 1727, removed to New Orleans and established himself in business there; and in 1761 married Pélagie de la Chaise, granddaughter of the Chevalier d'Arensbourg, of the Côte des Allemands. In the Cathedral records Forstall is registered simply as "a merchant of this city."

Two years before, Pélagie's sister, Louise, had married Joseph Roy Villere, the patriot who was killed by the Spaniards in 1769. Forstall took no active part in the rebellion against the Spaniards, but it is stated authoritatively that he used his influence with O'Reilly, whom his family had known in Spain, to save the life of his father-in-law, the 
old Chevalier d'Arensbourg who, heart and soul, despite his age had taken part with the revolutionists, and therefore had been listed by O'Reilly for punishment with Lafrénière and Villeré.

When the Spanish Government was organized' Nicholas Forstall was chosen Alcalde for several succeeding terms and was in office when the French took possession of the colony in 1803 . He had five children by his marriage with Pélagie de la Chaise: Edmond Pierre Charles; Félix Edmond; Félix Martin; Elizabeth Louise, who married J. B. Poeyfarre, in his day a noted planter and citizen whose name is preserved on a street that runs through the site of their old plantation. Their old plantation house is still standing on the street, a venerable reminder of a past day. They left no descendants. Emerante, the youngest daughter, married Jacques de Léry, one of the noteworthy Chauvin family and a first cousin of the famous Lafrénière.

Edouard Pierre Charles Forstall married Céleste Lavillebeuvre, the daughter of Jean Louis Verrault de Lavillebeuvre, Chevalier de Garrois. The six children born of the marriage formed what may be called the Forstall dynasty, that reigned over the social and financial world of New Orleans for a half century. Edmond Jean married Clara Durel. Placide married Marie Borgia Delphine Lopez y Angulla de la Candelaria, the daughter of Don Ramon Lopez y Angullo, an officer holding high rank in the service of Spain, and of his wife Delphine Macarty, who was a woman of such great beauty that when she went to Spain to solicit the protection of the Queen of Spain for her husband, who had incurred a mili- 
tary punishment, she did no more than kneel in a garden where the Queen took her morning walk. Her long black hair was unbound and hanging about her shoulders, her lovely eyes raised in supplication. The Queen stopped at sight of her, so young and so beautiful, and approached her with the words: "Your petition, whatever it is, is granted, you are so beautiful!" It may be said also of her that her daughters and granddaughters to the third and fourth generation merit the same tribute of admiration for their remarkable beauty. The daughter of Delphine Macarty, Delphine Lopez y Angulla, was born on board the ship on the young mother's voyage from Spain, to which circumstance the child owed the nickname of "Borquite" (from bord), which she bears even in the memory of the present generation.

The other children of Charles Edouard Forstall and Céleste de Lavillebeuvre were Felix Jean, who married Héloise de Jan, and Louis Edouard, who married Mathilde Plauché, the claughter of General J. B. Plauché, who distinguished himself at the Battle of New Orleans.

It is of tradition in New Orleans that the two young sons of Nicholas Forstall were put in the office of Panton, the great merchant, to learn business methods. It may be remembered that De Lino de Chalmette wished to do the same thing with his charge, Bernard Marigny, and thereby rather harmed than benefited him. The story is different about the two Forstalls. Panton's clerks, according to the rule of the house, lived with him, but had a separate table assigned them for their meals. The great head of the firm, however, noticing that the young For- 
stalls were superior in station and manner to the other clerks, had places for them at his own table, at which they thenceforth always had their meals. This apprenticeship was the foundation of the business development of the Forstall brothers and, it may be said, of New Orleans. The history of the house of Panton Leslie is yet to be written. Its rise to the ascendancy it acquired over the entire commerce of the Louisiana colony, holding in subjection as a collateral the trade of the great Indian tribes that still belonged to it, has but been glanced at by Gayarré and other historians, and the character of Panton himself only hinted at. He did more than any political power of his time to hold the vast country together in a common interest of trade, and he ranked with the Spanish Governors as a dominating influence. Panton impressed his type upon the Forstalls, and they transmitted it to the generation beyond them-the type of the great financier who accumulated great wealth while maintaining the ideals of a grand seigneur.

It does not take the memory of an octogenarian to-day to recall the type of the merchant prince of New Orleans-the patron of opera and theatre, distinguished by perfect courtesy of manner, not only in the world of society, but also in his business office: a dilettante of the fine arts, a linguist, speaking with ease, French, Spanish and English, a man who used his wealth as musicians do their instruments to produce results of art, who traveled to London and Paris as their successors to-day to New York and Chicago, bringing back with them the standards of Paris and London to apply to their own life.

Nine children were born of the marriage of Placide 
Forstall with Delphine Lopez. To belong to good society in New Orleans is to know them and their connections. Anatole married Pauline Gelpi Octave, Louise Forstall, his cousin. It was the daughters of the family, however, who carried its prestige in the nineteenth century. Women they were of such beauty that they became a proverb, and of such charm that its memory outlasts even the financial reputation of the men of the family. Céleste became the wife of Henry Alanson Rathbone; Emma married Emile de Buys; Pauline, Eugène Peychaud; Laure, Félix Ducros; Julia, Robert J. Taney, grandson of the Chief Justice of the United States; Delzire married Z. B. Canonge; Delphine never married but reigned a belle, even in her aged spinsterhood, not only in her native city but in Paris.

Henry Alanson Rathbone, who married Céleste Forstall, was the son of Samuel Rathbone of Stonington, Connecticut. John Rathbone, his ancestor, was one of the original purchasers of Block Island from Governor Endicott in 1660, and had a seat later in the Rhode Island General Assembly as representative of Block Island. Henry Alanson Rathbone came to New Orleans after the close of the War of 1812, and he is commemorated in social chronicles as one of the few Americans who was received with distinction in Creole society. He was a man of fine intellectual attainments, charming manners and brilliant conversation. His wife, Céleste Forstall, retained her beauty to old age. Her stately home on Esplanade Avenue, surrounded by a great garden, maintained its standard of old-fashioned elegance and its luxurious appointments long after the Civil War, which 
ended the old standards of living as well as the old régime in New Orleans. She left only daughters: Emma, who married John B. de Lallande de Ferrières; Pauline, who married Peter Labouisse, Esq.; Stella, who became the wife of James Gaspard de Buys;* Alice, who married William Phelps Eno of New York; Rita, who married Edgar de Poincy. Edmond, the eldest of the four sons of Edouard Forstall and Céleste Lavillebeuvre, is the one whose name is most often repeated when the family is recalled. From 1832 until 1872, when he died, he held the agency for New Orleans of the Baring Brothers of London, and Hope and Company of Amsterdam, from whom at one time he negotiated the sale of bonds issued by the State in favor of the Citizens Bank, amounting to one million dollars. He was also instrumental in framing the law for the incorporation of free banks in Louisiana. In short, to quote the current account of him in the newspapers when he died, he was the leading spirit in all financial banking and insurance companies in New Orleans for half a century. And it must never be omitted from his history that he fought in the Battle of New Orleans, as corporal of the celebrated (or once celebrated) Battalion d'Orléans. This was Plauche's battalion, which ran the whole distance from Bayou St. Jean to Chalmette to join the column of attack. Many of the battalion were delicate young Creole boys, yet they bore their heavy muskets and knapsacks with as much ease as practised veterans. As Alexander Walker, the laureate historian of the battle, says to them: "With their gay

*Rathbone de Buys, Esq., the eminent architect of New Orleans is their son. 
and varied uniforms, characterized by that good taste and regard for proportion and effect which distinguished the French race, with their bold, handsome countenances and uniform size, the Orleans battalion was certainly a corps of which any commander might be proud."

Forstall also owned and cultivated a large sugar plantation in the parish of St. James, a plantation that is still cited as one of the great plantations of the State in ante-bellum days when sugar plantations were, so to speak, in their glory. Upon it he adopted -one of the first Louisiana planters to do so-the advanced scientific discovery of the vacuum process of making sugar. It was a costly experiment and it needed the daring of independent wealth to carry it through satisfactorily, as Forstall did, thereby proving himself to be, like Boré, one of the great benefactors of the sigar interests of the State.

He proved himself, too, a benefactor in other interests not profitable financially. As has been said in the life of Charles Gayarré, Edmond Forstall made a valuable contribution to the Historical Society at the time when Gayarré revived it and inspired it by his own brilliant example. When François Xavier Martin, the historian, was elected president of the society, Gayarré headed the Executive Committee. Under him were, besides Forstall, de Bow, the owner and publisher of the best of all magazines ever attempted in the southern country, ${ }^{*} \mathrm{~J}$. B. French, the publisher of "French Historical Collections," and John Perkins, that rich lover of Louisiana history, to whom primarily historical students are indebted for the superb work of Pierre Margry,

*De Bow's Review, afterwards the Southern Quarterly Review. 
published in the United States by act of Congress.

Never has such a brilliant group of workers in the historical field ever been gathered in the fold of the society, and never, it is to be feared, can there ever be such a group gathered in the future. It was Forstall who caused to be made the first and, in fact, the only analytical index of the whole of the public documents relative to Louisiana deposited in the archives of the "departement de la Marine et colonies" and "Bibliothèque du Roi," at Paris. An amazing piece of work as we see it to-day, accomplished in full perfection of form and detail! The index was published in the proceedings of the society by J. B. French in his Historical Collections, and were afterwards reprinted in De Bow's Review (Vols. I and II). In addition, Forstall contributed many interesting articles on agricultural and commercial subjects to the Review.

By his marriage with "the beautiful Clara Durel," to give her her proper local title, he had four sons and five daughters: Eugène, married to Lize Cantrelle; Victoria, to de Lavillebeuvre; Henri, to Mathi'de Plauché; Ernest, to Mathilde Taney; Oscar, to a Demoiselle St. Maurice Berault. Desirée, the eldest daughter, became Madame Charles Roman; Eugénie, Madame Valerien Chopin; Héléna, Madame Adolphe Shreiber; Leda, Madame Charles Olivier; Anna, Mrs. Arthur Polk.

The old home on St. Louis Street was built for a large family with its numerous attendants: a princely establishment, it was called, in the language of visiting strangers who traveled to the Creole city to enjoy its foreign aspect and pleasures. The simple, 
plain exterior was the ideal of the architect of the time, an ideal that enjoined the contrast of a severe external appearance with great interior luxury: an ideal that no one better than Edmond Forstall knew how to flatter, with his great library of handsome books, his bronzes and pictures. No article, no piece of furniture that was not fine and of perfect taste, could pass his portal.

He weathered, like a well-built hip, the storm of the Civil War, and by an honest seamanship that has never been questioned brought his large fortune through intact. Four sons volunteered for active service. Eugène was compelled by illness to resign from it; he died during the war. Henry also was forced to resign on account of ill health; he died on the day of the Battle of Shiloh. Ernest, more fortunate, fought during the four years and was twice wounded. Oscar fought during the duration of the war.

Note.-Taken from the published record of the Forstall family, written by Charles Patton Dimitry.

From the marriage of Jean Felix Forstall (fourth son of Edouard Pierre Charles and Héloise de Jan) were born: Arthur, Paul William Suzanne (Mrs. Duplantier), Angèle (Mrs. Emile Duplantier), and Mrs. Octave Forstall.

Delzire Forstall (Mrs. Z. B. Canonge) left: Rosa (Mrs. George Binder), residing in France, and Cora.

Eliza Forstall (Mrs. Delphine Villeré) left two children: Edouard, who married Marie Bouligny, and Placide Villeré, who married Miss Cantrelle.

Felix Edmond Forstall married Marie Adélaide Josephine de Morant, daughter of Charles de Morant and Catherine Amelot. Their ehildren were: Coralie (Mrs. Gustave Durel), Helmina (Mrs. Anatole Villeré).

Felix Martin Forstall married Marie Celeste d'Aunoy, daughter 
of Charles Farre d'Aunoy and Catherine Macarty. Their children were: Charles Edouard, who married Mademoiselle de Poincy, daughter of Rossignol de Poincy. Their only son, Charles Oscar Eugéne Forstall, resides in Paris.

The wife of Comte Seminiatelli, of Italy, belongs to the de Poincy branch of the Forstall family; her mother was Madame Edouard Le Beau.

Anatole Forstall, his cousins, William Forstall (son of Felix,) and Placide (son of Octave), Victor Ernest and Adolphe Forstall resided till their death in New Orleans.

Eugène Forstall, the son of Charles Edouard, lived in France, where he was in the employ of the French Government.

Theobald was the son of Alfred Forstall, a graduate of Yale. $\mathrm{He}$ inherited the intelligence and executive qualities of his family and was noted for his administrative ability. After occupying the position of Superintendent of the New Orleans Gas Company for several years, he was offered the same position in Chicago and accepted it. He died there in 1901, leaving several children. 


\section{CHAPTER XXVII}

\section{MACARTY}

7 HE good old Creole name of Macarty has become 1 only a memory in New Orleans. The male members of the family are extinct, but the female members have carried the Macarty traits and qualities into the other old families until there is hardly one that does not bear a representative in their genealogical record.

The family (originally Macarthey-Mactaig) was a noted one among the great Irish families, who preferred exile to the religious and political tyranny of their English conquerors. In the seventeenth century Bartholomew Macarty, of the Albemarle Regiment, sought refuge in France, where he gained promotion in the navy and died a Chevalier of St. Louis and Major-General of Division in the department of Rochefort. His two sons, Jean Jacques and Barthelmy, came to Louisiana in 1730, the former as commander of a marine detachment, the latter as a lieutenant in the same command under him.

Jean Jacques married Dame Françoise de Trépagnier, and his two sons returned to France, where they took service in the royal army: the one in the marine, the other in the Mousquetaires or household troops of the King. The latter married in New Orleans Jeanne Chauvin, and at her death passed again into the service of France and became aide to 
Count d'Estaing on board the "Fendant." He died in New Orleans in 1793 . Both brothers were made Chevaliers of St. Louis.

Barthelmy de Macarty (as he was called) cast his life in New Orleans, where he married Dame Françoise Hélène Pellerin, who bore him eight children. From a lieutenant he rose to a captaincy in 1732 , and four years later filled the responsible position of Aide Major of the city.

The Natchez massacre of 1727 had put an end to the old easy-going days; the Company of the West under the threat of the impending destruction of the prosperity of the colony by an Indian war, hastily remitted their charter to the royal government, and Louisiana returned to the wardship of the King. Governor Périer was at once recalled and Bienville put in power again, as the only man available to cope with so serious a situation. He immediately set out to punish the Natchez and their allies, the Chickasaws and Choctaws, using what military force the colony furnished, and calling on the home government for reinforcements. Macarty accompanied him on his first futile effort to bring the Natchez tribe to submission and later took part in the fatal expedition against the Chickasaws in their village in upper Alabama, which resulted in the bloody defeat of the French and the final and lasting disgrace of Bienville in the eyes of the French Government and his recall from Louisiana.

He included Macarty in the list of officers serving under him: "Chevalier de Macarty came into colony in 1752, Aide Major of New Orleans. Conduct good. Understands detail and discipline Attached to the service and doing well." 
Vaudreuil succeeded to Bienville. He also led an army against the Chickasaws and was no more successful than his predecessor had been. War having been relighted in Europe between the English and French, the colonies of the rivals sprang also to arms in America. Traveling along the Mississippi became a perilous adventure and life in the river settlements most insecure.

Vaudreuil was made Governor of Canada and Kerlerec sent to Louisiana to replace him. Macarty was put on duty as commander of Fort Chartres on the Mississippi, above the Ohio, the chief seat of the French influence among the Indians. Here he remained until the final triumph of the English. The historian, Villiers du Terrage, quotes a spirited letter from him to Kerlerec in which he gives the account of the capture of Fort Niagara by the English. Du Terrage praises his clear and accurate judgment and exclaims sadly: "It is a pity for France that this brave and efficient officer was not given more opportunity for displaying his capacity."

Macarty's presage of defeat was confirmed during the summer following, when the news came of the surrender by France of all her American possessions, except the Orleans territory, to the English. Macarty returned to the one French post remaining, and died in New Orleans about the time the news came of its transfer to the Spanish. He left four sons and four daughters. They were not the only bearers of the name in Louisiana. The Chevalier Jean Jacques de Macarty, his elder brother, who had married Dame Françoise de Trépagnier, left two sons and three daughters, all born in New Orleans. Only one son, however, Augustin Guillaume of the 


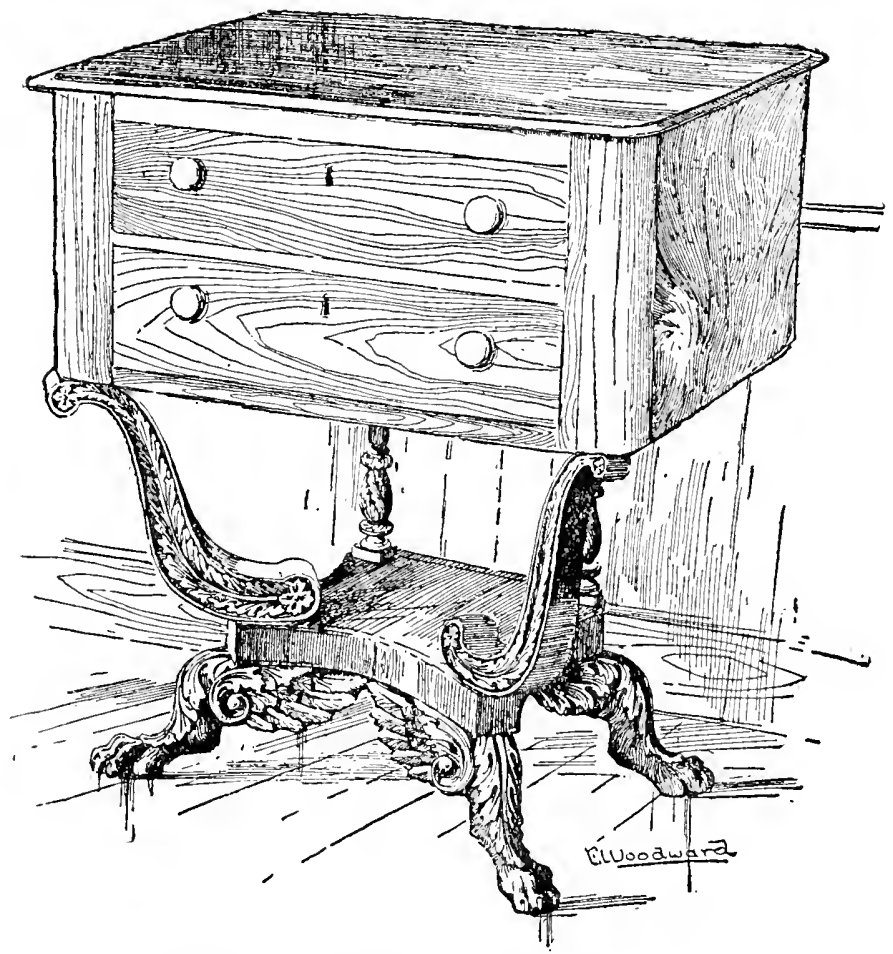

Empire Work Table of St. Domingo Mahogany and Brass. 

Mousquetaires du Roi, who married Jeanne Chauvin, left descendants.

The sons of the Chevalier Barthelmy Macarty, who married Françoise Hélène Pellerin, were as follows: Jean Baptiste François, who married Hélène Charlotte Fazende (daughter of Réné Gabriel Fazende and Charlotte Dreux, daughter of Mathurin Druex). Barthelmy Louis, the second son, married the Widow Lecomte; his daughter was the beautiful Delphine Macarty, who married Don Ramon Lopez y Angullo and became the mother of the no less beautiful Marie Françoise de Borja de Lopez y Angullo ("Borquite"), who married Placide Forstall and became the mother of twelve children from whom descend the great New Orleans families of Forstall and Rathbone.

Augustin Macarty, the son of Augustin Guillaume and Jeanne Chauvin, became, under the American Domination, Mayor of New Orleans for several terms. Gayarré has left a description of him that obtrudes itself whenever his name is mentioned

"Macarty is of an ancient and high-toned family. He has served several times as Mayor of the city and is uncompromisingly conservative in all his views and feelings-the embodiment of the old régime. It was he who, in his official capacity as reporter, and backed by public opinion, caused the first cargo of ice brought to New Orleans to be thrown into the river as a measure of public safety, because cold drinks in summer would affect throats and lungs and would make the whole population consumptive."

His first cousin, Jean Baptiste Macarty, always a supporter of the American Domination, became colonel of a regiment of militia and a member of the Legislative Council, and served under Claiborne as Secretary of State. Ile died in 1808 and was buried 
with military honors, "an excellent citizen and faithful officer," writes Governor Claiborne to the commander of the war vessel in port, asking that minute guns be fired by the vessels of war in port during the funeral ceremony.

It was not the men of the family, however, but the ladies who, as we may say, irradiate the pages of the chronicles of New Orleans; the daughters of the Chevalier Barthelmy Macarty and Françoise Hélène Pellerin. They were: Françoise Brigitte, Marie, Catherine, Adélaide, Céleste Eléonore, Louis Eléonore, and Marie Marthe.

Françoise Brigitte was the Madame Nicolas d'Aunoy whom the Baron de Pontalba celebrates as the most charming of all the charming aunts of his wife. She lived in the city in a large house facing the river and was the center of life and gayety of the family. Marie Catherine Adélaide became Madame la Comtesse Fabre de la Jonchère, whose plantation opposite the city was the stage for innumerable gay social functions in the time of Governor Carondelet.

Jeanne Françoise, according to the Cathedral register, was married to "Messire Jean Baptiste Césaire le Breton, son of Messire Césaire le Breton, écuyer et Seigneur de Boussou, Charmeau et autres lieux, conseiller de la cour Souvereigne de Paris, and of Dame Marguerite Chauvin de Lafrénière." (It may be recalled here that the first husband of Marguerite de Lafrénière was Noyan de Bienville, executed by the Spaniards). The daughter of Césaire le Breton and Françoise de Macarty became the wife of Baron Delfau de Pontalba.

But the most brilliant marriage of the family was 


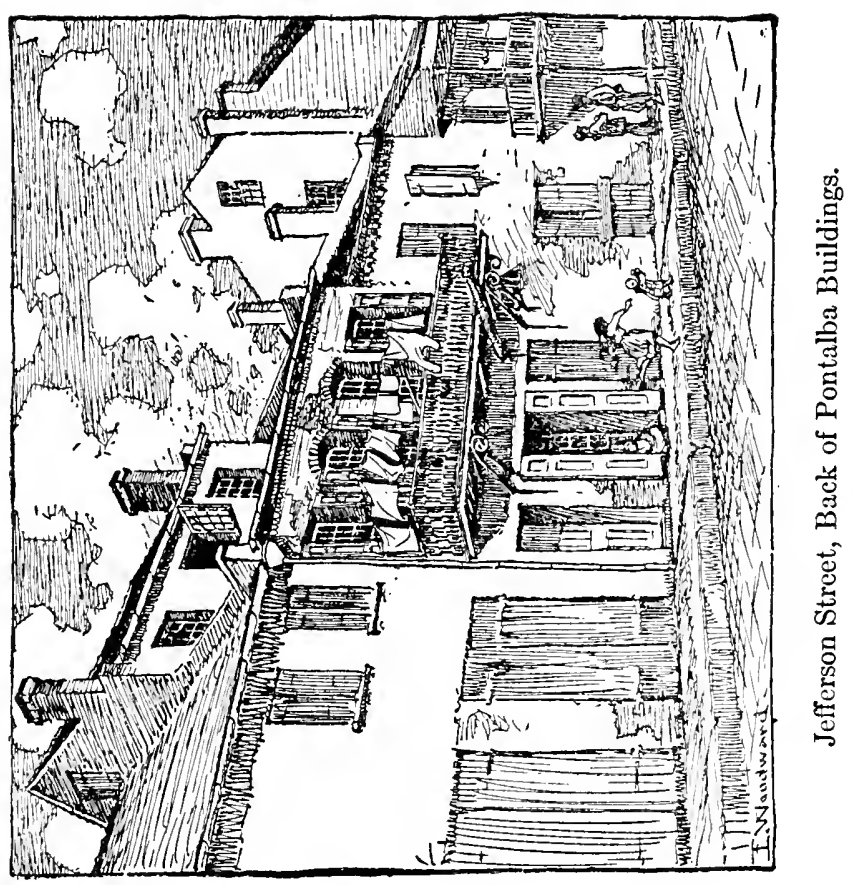



that of Céleste Eléonore Elizabeth with Governor Miro, the successor of Galvez. She it was, more than her worthy husband, who reconciled Louisianians to the Spanish Government. She was young, beautiful and all Irish by her quick wit. Passionately fond of theatricals, she played the principal rôles herself in the little dramas given in her hôtel to which she invited all the élite of the population, and she was indefatigable in her bright stratagems to while away the dull cares that oppressed the minds and made heavy the hours of the Spanish officials. New Orleans had never been so gay as under her. husband's or rather her administration with the opera, theatre, balls, card parties and pleasure jaunts to the suburb of Bayou St. Jean or across the river to the plantation of her aunt, Madame Jonchère. She knew as a good society woman how to turn it all to such good account that New Orleans began to be known all over the American continent as the city upon it most worth living in by pleasure seekers. The great conflagration that had apparently wrought only ruin and desolation during her husband's administration proved a blessing in disguise, as the small, homely French buildings were soon replaced by stately edifices of Spanish architecture; the Cabildo, the market, the Cathedral, the large courtyard houses with their cool alleys, great stairways and spacious living rooms, their decorative knockers and grill work enclosing their galleries. When Miro obtained at last his permission to retire to Spain, he left Louisiana not only reconciled to Spain, but even endeared to it and beautified by its domination.

Madame Miro accompanied her husband to 
Spain in 1791, and when he died she was so brokenhearted that her niece, Madame de Pontalba, hastened to her and remained with her until de Pontalba could join them, when they journeyed to France. Madame Miro did not separate again from the Pontalbas but accompanied them to France and passed the rest of her life with them at Mont l'Eveque, near Senlis. A sister, Françoise, also joined her and remained with her until death, which came to her in her eighty-eighth year. Madame Miro survived Françoise but a few years. Both are buried in the parochial church of Senlis.

Which of the Macarty sisters it was who gave the rebuke to O'Reilly we do not know. Gayarré relates it, not mentioning her name, but we can identify her by the fact of her living on a plantation up the river, as the same lady whom he describes as a friend of his grandmother. He says that O'Reilly's carriage, escorted by a few dragoons, was frequently seen driving at a rapid pace up the coast, where he used in his moments of leisure to visit a family residing a few miles from town, in which he found himself in an atmosphere reminding him of the best European society. One day when according to his habit he had provoked a keen encounter of wits with the lady of the manor, being stung by a sharp repartee, his hasty temper betrayed him and he forgot himself so far as to say, with a tone of command, "Madame, do you forget who I am?" "No, sir," answered the lady with a low bow, "but I have associated with those who were higher than you are, and who took care never to forget what was due to others; hence they never found it necessary to put any one in mind of what they were." Nettled, 
O'Reilly departed instantly but returned the next day with a good-humored smile and apology.

Speaking of his grandmother's friend, Gayarré introduces her thus:

"The plantation above the de Borés', which extended over Audubon Park, belonged to Pierre Foucher (de Boré's son-in-law); the next place belonged to the unfortunate Lafrénière. It was at that time the property of Mademoiselle Macarty, who was Madame de Bore's intimate friend as well as neighbor, and who, like her, had been educated at St. Cyr."

It was one of the great pieasures of Gayarrés friends to hear Mademoiselle Macarty described by the historian, then in his nineties, and see one of her visits to his grandmother, three quarters of a century before, acted. Her carriage, a curiosity unique in the colony, was called a chaise; it was like a modern coupé but smaller, with sides and front of glass. There was no coachman; a postillion rode one of the spirited horses, a little black rascal of a postillion who always rode so fast and so wildly that his tiny cape stood straight out behind like wings. When in a cloud of dust the vehicle turned into the Pecan Avenue the little darkies stationed there to look out would shriek in loud excitement to get the announcement to the great gates ahead of the horses: "Mamselle Macarty a pé vini." And there would be a rush inside to throw open the gates in time. With his cape flying more wildly than ever, his elbows beating the air more furiously, the postillion would gallop his horses in a sweeping circle through the great courtyard and bring them panting to a brilliant finale before the carriage step. M. de Boré would be standing there ready with his lowest bow to open the carriage door and hand the fair one out and lead 
her at arm's length with a stately minuet step up the broad brick stairs and through the hall to the door of the salon, where they would face each other and he would again bow and she would drop a curtsy into the very hem of her gown-her Louis XIV gown-for from head to foot she always dressed in an exact copy of the costume of Madame de Maintenon; that is, with the exception of her arms, which were in Mademoiselle Macarty's youth so extremely beautiful that she never overcame the habit, even in extreme cold weather and old age, of exhibiting them bare to the shoulder. The mystery of why with her great wealth and great beauty she had never married remained a vivid one-even when old age had effaced everything except the fame of her radiant beauty.*

Gayarré, who always looked at the history of Louisiana with romantic eyes, looked also at the romance of Louisiana with historical eyes. We are not surprised, therefore, to find in the pages of an old number of Harper's Magazine a little story in which he gives an authentic account of the Macartys in the early years of the last century. $\dagger$

"Mademoiselle Macarty lived near the de la Chaise plantation, once well known on account of its brickyard, but now divided into streets and lots that have become a part of New Orleans. She was in affluent circumstances, possessed houses in the city and owned a number of slaves. She had a beautiful and productive garden of which she was very proud, superb orange trees and a well cultivated orchard, and acquired considerable reputation for the skill with which she manufactured all sorts of condiments, sweetmeats and other delicacies. In this she was assisted by a dame de compagnie.

* "New Orleans: the Place and the People." Grace King.

$\dagger$ Barthelmy Macarty's Revenge." IIarper's Magazine, 1887. 
"Mademoiselle Macarty left all her fortune to her nephew, Augustin Macarty, who subsequently became Mayor of New Orleans and died childless. She had another and more distant relative called Barthelmy de Macarty. . . . His son, Barthelmy, had been thoroughly educated and gave promise of a brilliant career. When still very young he had been selected by Governor Claiborne for his Secretary of State. Handsome, possessed of those cleancut features which characterize the patrician of long descent, rich and distinguished in every way, the youthful secretary was a cynosure of society.

The two brothers, Augustin and Barthelmy, are mentioned prominently in the reports of the Battle of New Orleans, and in the measures taken to prepare the city against the English. Augustin was appointed on the Committee for Public Defense and was among the citizens who subscribed ten thousand dollars toward securing it. The Macarty plantation shares with the Chalmette and the de la Ronde places the hoinor of furnishing the field for the glorious battle. Jackson established his headquarters in the Macarty house, a handsome house built in the new, at that time, château style with galleries extending all around it, supported on brick pillars. The trees and foliage of the garden screened it from the road, and it was from the gallery of the old mansion, whose garden lay just within the American line of entrenchment, that he on the afternoon of January 7 th, 1815, observed the movements in the British camp, two miles down the river, and came to the conclusion that they were preparing to attack him. About one o'clock that night an aide, sent to make a report to the General, found him sleeping on a sofa in one of the front rooms; his staff were stretched out on the floor about him. Having heard the report, he looked at his watch and 
exclaimed: "Gentlemen, we have slept enough. Arise. The enemy will soon be upon us." All immediately left the house for the camp. They had hardly done so when a cannon ball, fired from the British lines, crashed into the room where they had been sleeping.

A last memorable scene connected with the old house must not be omitted. On the morning of the 19 th, and when the armistice had drawn to its end the exchange of prisoners had been effected and speculation was rife as to what the British Army would do further; a rumor circulated through the American camp that it had retreated. Officers and men collected in groups to survey the enemy's camp, and much discussion arose as to whether the army had really gone or was only lying in wait to entice the Americans from their entrenchments. General Jackson and his staff, stationed in the window of Macarty's house, gazed at the camp through powerful telescopes. It presented the same appearance as usual; flags were flying, sentinels posted. The General was not satisfied that they had gone. His aides thought as he did. At last the French General, Humbert, standing near, was called upon for his opinion. Napoleon's veteran took one look through the telescope and immediately exclaimed: "They are gone." When asked for his reason he pointed to a crow flying near one of the sentinels which showed that they were stuffed dummies. The British had stolen away during the night.

A pretty public square in the old part of the city, called Macarty Square now, commemorates the upper lines of the Macarty plantation. In it has been erected a handsome memorial arch to the heroes of the late war. 


\section{CHAPTER XXVIII}

\section{DE BUYS}

THERE is a tradition that this good old typical 1 Creole family was among the early French settlers of the colony, and that its head was present with Bienville at the laying out of the city of New Orleans.

The first de Buys known in the records of New Orleans, Gaspard Melchior Balthazar, the son of Pedro de Buys and Micaela Lion (in the Spanish of the Cathedral records), was born in Dunkirk in 1789 . His forebears were seafaring folk who had sailed their ships under letters of marque from Louis XIV and fought as privateersmen in the wars against England. Gaspard, so the story goes, was captain of a man-ofwar under the Count de Grasse during the war for American Independence but, having caught the yellow fever in the West Indies, he resigned from the navy and came to New Orleans, then in the peaceful days of the Spanish Domination. Here he shortly afterward married Eulalie de Jean or de Jan, daughter of Antoine de Jan of Bordeaux and Angele Monzey de Montjean, a native of New Orleans.

The mother of Angele de Montjean, according to the family record kindly furnished by Mrs. Lucien de Buys of New Orleans, was saved from the Natchez massacre by her nurse, a young Indian girl, who bravely tramped her way through forests and Indians and brought the infant in safety to New Orleans. 
She grew up in the city and married Claude de Jan about 1750 . He had been established in business in New Orleans for some years. They had six children: Eulalie, Antoinette, Marie Françoise, Manette, Jean Baptiste and Claude.

Madame Montjean lived, says the record, to be over one hundred years old, and was visited in her home at Santiago, Cuba, by one of her great-granddaughters of New Orleans. The de Jan children married in New Orleans and ramified in France and in England, where many of their descendants still live.

Gaspard de Buys seems to have been among the Creoles of his day who viewed with indifference the passing of the colony from Spain to France and from France to the United States. His name does not appear in any of the reports of the proceedings attending the ceremonies involved in the raising and lowering and raising again of the different flags. And he did not, apparently, take part in any of the demonstrations of violent discontent that followed, when Congress decreed that the new possessions should be governed as a territory, and not given the sovereign rights of a State, as had been stipulated in the Act of Cession. His name, however, docs appear in the first Legislative Council named by the President in the inauguration of the new government. Although historians are strangely uncommunicative about them, perhaps no body of men in the history of Louisiana has ever had so many and such important political problems to solve as that first Legislative Council of Louisiana, and none have ever received so little recognition of the value of the services they rendered. 
Gaspard Melchior de Buys and Eulalie de Jan had four children: Pierre Gaspard, William, Manette and Adèle. Pierre Gaspard, born in 1790, married, in 1811, Jeanne Clemence, daughter of Jean Antoine Viel and of Jeanne Rosa Dupuy. The Viel family, like that of the Montjean, barely escaped extermination by massacre. They came originally from Lorraine to St. Domingo, where Jean Antoine became a large landowner. Having always been a good master to his slaves he did not fear the revolution, and refused to flee when urged to seek refuge in a vessel about to sail to France. He, his mother and son were massacred; his wife and daughters were saved, the youngest one, a baby, being safely hidden by her nurse in a well. They found a refuge among relatives in Santiago.

Pierre Gaspard was so exuberantly republican in his feelings that he indulged in an exhibition of them that is carefully transcribed in the family record. When his eldest son Pierre was born he gave him a political as well as a religious christening feast, inviting all of his friends to it, and requesting them to bring with them their patents of nobility (for, as we have seen, the good French families emigrated to Louisiana with their patents of nobility carefully packed in their boxes). On the festal board stood a large silver chafing dish; the patents of nobility were placed upon it, fire lighted underneath, and the infant Pierre was passed over the smoke of the burning titles amid cheers and plaudits.

The other children--Marie Elizabeth Eugénie, Paul, Emile, Marie Antoinette Odile, Eugéne, Lucien, Napoleon-showed in their names at least a broadening catholicity of political convictions. De 
Buys served on the staff of General Jackson at the Battle of New Orleans, and it is one of the pretty memories preserved faithfully in the family that at the grand ball given by the Governor to celebrate the victory, the General, whose eye was never dull to beauty or to politics, asked his aide-de-camp, de Buys, who a certain very beautiful lady was. $\mathrm{He}$ answered that she was his wife, who, though still so young, was the mother of two children. Her sister, it is said, was also a noted beauty in New Orleans, and the same reputation was inherited by her daughter Eugénie.

In the resolutions passed by the Legislature after the victory in 1815, there is this handsome compliment to his father:

"Whilst our gallant militia were employed in the defense of the country, at the several posts assigned to them, the eitizens more advaneed in years, having voluntarily formed themselves into companies of veterans, attended to the preservation of police and civil order in town. They greatly contributed by their good countenance to dissipate the alarm ereated by the approach of the enemy and by their unwearied exertions they insured the speedy and faithful conveyance to camp of such artieles as were to be sent there. They were also usefully employed in seeing that the many donations made by our fellow eitizens should be both applied and without confusion. At the head of these veterans appeared M. de Buys, their captain."

After the War of 1812, William de Buys, with other ambitious spirits, had to be content with civic ambitions. He was elected to the Legislature and became Speaker of the House in 1846. He was pushed forward by his party as candidate for governor to succeed Governor Roman, and he proved a sharp competitor for Isaac Johnson, who was elected.

He lives in memory, however, still more vividly 
perhaps as commander or general of the Louisiana Legion. This was, as should be explained to readers foreign to New Orleans, a famous military organization that for a score of years nourished the popular craving for military glory that has always been endemic in the place. Its germ was the Batallion d'Orléans, * that corps d'élite of young Creoles recruited only from the Creoles or Frenchmen who had seen active service. They were perfect in every detail and always ready for immediate service. When the call to arms came in 1814, the Bataillon d'Orléans stepped into the field of action fully armed and equipped and proved themselves trained veterans under fire-Jackson himself praising their prowess and efficiency.

After the war, the battalion increased in strength and stability so rapidly that it was necessary to incorporate it into a Legion, which was commanded in succession by such generals, in repute, as Augustin Cuvellier, de Buys and Lewis. Its ranks were opened to every nationality - the companies bearing the names of Jaeger, Cazadores, Cuirassiers, Lanciers, Emmett Guards, Sappers and Miners. There was among them even a company of mounted Mamelukes. They paraded on the Fourth of July and other patriotic dates, and were reviewed by the Governor on state occasions, but it was on the Feast of Ste. Barbe that they shone in their full glory, when they turned out in splendid array and marched through the crowded streets, with bouquets stuck in their muskets, to the Cathedral to hear mass and be blessed by the Bishop (when they took up a collection for the asylums of the

"New Orleans As It Was." Castellanos. 
city). Their banner was presented to them by the Governor in the Cathedral after being blessed. When the war with Mexico was declared and volunteers were called for by General Taylor to go at once to the Rio Grande, the Legion answered within twenty-four hours, readily furnishing the contingent required; and the daily papers noticed on this occasion that William de Buys (having been succeeded in his command) walked in the ranks, a musket on his shoulder, beside his two sons.

$\mathrm{He}$ retired in his old age to his beautiful home at Biloxi on the lake shore, where he passed his time fishing and humting and painting in water colors. He invented a fishhook for deep-sea fishing that is still in use by fishermen of the Gulf. He died there in 1774. By his wife, Corinne Andry, he had four children: Felicie, Gaspard, Ovide and Hortaire. John de Buys, the noted duelist, was an adopted son taken from his Irish mother's arms when she died of cholera.

To return to the head source of the family, Gaspard Melchior de Buys and Eulalie de Jan, their eldest daughter Manette married Pierre Victor Amedée Longer of Rouen. She is ever cited in New Orleans as a woman of wonderful accomplishments; a perfect wife, a model housekeeper, an exemplary society woman; grave, serious, dignified, and although beautiful above her associates, never condescending to be a belle. She was left a widow with eight daughters still in childhood. They grew up beautiful, with all the good qualities of the mother, and noted more than she had been for charm of conversation and manner. It is of tradition that every eligible man in the city offered himself to 
one or the other of them. Their choice was decided by the mother's sagacity. All were married well to men of standing in the community and all were happy in their marriages and were blessed by children worthy of them. Not to know the names of the married Longer ladies is regarded in the Creole city as proof of unpardonable social ignorance. Eulalie became Mrs. Samuel Bell; Adele married Florian Hermann; Odile, Michel Musson; Armide married Amedée de Saules; Amélie, James Behn; Angèle, Evan Jones McCall; Heda, Charles Kock; Helena, Charles Luling. Mrs. Luling's daughter is Lady Alice Ben, wife of Sir Arthur Ben, M.P., London.

Gaspard de Buys died in 1827; his daughter, Madame Longer survived him a half century, a cherished relic of other and far different days, respected and revered by all, served by her old servants, relics as she was of older times. Children and grandchildren and great-grandchildren came to her from their distant homes in England, France and the United States. She passed away in the home of her daughter, Mrs. James Behn, on South Rampart Street. No statelier procession of mourners than that which followed her up the aisle of the church to her grave in the old St. Louis Cemetery has ever assembled in New Orleans.

General de Buys' eldest daughter, Felicie, married A. J. Mummy, Esq., of France. She had two daughters. One married M. Schroeder, ConsulGeneral for Germany in France; the other married M. le Comte de la Guerronnière, of Haute Vienne, France.

The General's sisters and brothers, the children 
of Pierre Gaspard de Buys and Elizabeth Viel, were: Marie Elizabeth, who married twice, her first husband being Hypolite Tricou, her second one, Samuel Herman. Estelle Tricou, the daughter of the first husband, married Bernard Peyton of Virginia (their son, William Charles, married Anne Dupont). Samuel Herman's daughter, Alice, married Henry Palmer, and their daughter May became the first wife of the Hon. Chauncey Depew. Louise, the second daughter of Samuel Herman, married Hall McAlister of Georgia.

Paul Emile, the son of Pierre Gaspard and Elizabeth Viel, married Emma, the daughter of Placide Forstall of New Orleans. Their son, Gaspard James, married Stella Rathbone, and from them descend the four well-known brothers who bear the de Buys name at present in New Orleans: Rathbone, the distinguished architect and archivist of his family; Lawrence, an eminent physician; Walter and James.

Marie Antoinette Odile de Buys was married twice; first to Joaquin de Vignier of Havana; afterwards to Foster Elliot of New York. Children and grandchildren of both husbands survive. : Pierre Victor Amedée married Cécile Denis, daughter of Henri Denis of New Orleans. They had two children: Alfred, who lives in New York, and Amélie, who married the late George C. Préot of New Orleans, a distinguished littérateur and educationalist.

Lucien Napoleon Eugene de Buys married Lucile Elizabeth Enoul Dugue de Livaudais, the descendant of the two old and distinguished families of Livaudais and Dreux. She and her husband, during their long married life, brilliantly maintained the prestige of their name and blood in their home and society 
and were always proudly cited as examples of what the good old Creole families really were. They were blessed with fifteen children, twelve of them daughters.

To Madame Lucien de Buys, who since her husband's death has gathered together the dates and documents relating to his family for the use of future generations, is due the sincere acknowledgments of the present writer. 


\section{CHAPTER XXIX}

\section{CANONGE}

THE great heroic and historic days of New Orleans 1 passed away and the chronicles of the city, once set to the accompaniment of martial music, now move along to the soft and somewhat monotonous strains of domestic and social life. The city, in short, is like a lady who, having passed through a youth of anxious experiences and arrived at a middle age of ease of mind and comfort of body, can tolerate in her journal only pleasant and ornamental entries. And pleasant and ornamental in the journal of the city is the good name of Canonge.

Mrs. Emma Canonge Nott has left her intimate notes written for family use, to which access, in the present instance, has been graciously granted.

"The maternal grandmother of my father," she writes, "was the Marquise de Jusseau. Her husband was in the service of France under Louis XV, and we still possess his commission signed by the King. The only daughter of the Marquise de Jusseau, Elizabeth Renée, was seventeen when she married my grandfather, twenty years older than she.

"The marriage was a happy one and was blessed with eight children born in St. Domingo. When the revolution broke out upon the island, my grand- 
mother, who was a widow for the second time, having married her cousin, M. de Montage, left St. Domingo and went to St. Iago, Cuba, leaving her wealth behind her, invested in a sugar and a coffee plantation. Thirty devoted slaves followed her. My father (J. F. Canonge) was reared in Marseilles by his uncle, Major Canonge, a Chevalier of St. Louis. He was an officer of distinction in the French Army, whose devotion to the Royalists' cause was to cost him dearly."

Recalled by his family, young Canonge left Marseilles and returned to St. Domingo, but was driven away again by the insurrection of slaves and took refuge in St. Iago. While there he was fired with the idea of gaining the island of Cuba and turning it over to Napoleon, thinking that the very sound of this great name would smooth away all resistance. But his plot was discovered and a price put upon his head. He made his escape and joined his two brothers in Philadelphia. His French education proving a hindrance to a commercial career, he turned to the law and studied under the celebrated jurist Duponceau.

After receiving his diploma, he naturally gravitated toward New Orleans, where the French element was still the predominating one in social and professional life. There he took his position at once among the group of men still considered the most distinguished in the history of the Bar.

In New Orleans he married the young widow Amelung, born Mercier, a cousin of the Mademoi selle Clary, who married Bernadotte, afterwards King of Sweden. "My grandmother, Mercier," continues the little manuscript, "was a Demoiselle 
Fontenelle, of the same family as 'le grand Fontenelle,' who was related to Corneille. The home of my father and mother was a most hospitable one, all visitors of distinction were presented in it; the Prince of Wagram, Lafayette and General Desnouettes; who gave to my mother the precious souvenir of five letters of Napoleon written (still in existence) to him."

At the time of his arrival, French and English were both used on the floor of the House of Representatives. Canonge filled the position of clerk of the House for several sessions. Possessed of an incomparable memory, he took no notes of discussions and debates, and although it frequently occurred that in the official proceedings translations were required from one language to the other, he made them without omitting any important feature and frequently reporting the words literally. $\mathrm{He}$ made a name as orator, linguist and improvisator, speaking impromptu in French, Spanish or English. He was called in his day-oh, golden day of social intercourse!-an accomplished conversationalist, and when he talked men gathered around him to listen; he was also a ready rhymester and astonished, on two occasions, his audience by delivering addresses in verse. And to add to his accomplishments, he translated the Georgics of Virgil into St. Domingo Creole patois.

His success at the Bar secured for him the appointment of Judge of the Criminal Court by Governor Roman. At that time the Criminal Court was unique in its character; from it there was no appeal. He filled this position for ten or twelve years, distinguishing himself by his enlightened legal views 
and by the impartiality of his charges to the jury. A legal incident in his career is mentioned by his biographer.* On one occasion the celebrated Judge Xavier Martin, Chief Justice of the Supreme Court, intimated to Judge Canonge that in a certain case he should accord a new trial; Canonge refused to comply, and although the Supreme Court persisted in its demands, the Criminal Judge, alleging that there was no appeal against the decisions of his court, continued firm in his position. The result was that the Supreme Court issued an order for his arrest for contempt of court, which was met by Judge Canonge ordering the arrest of five judges of the Supreme Court for the same offense. The operations of the two courts were suspended in consequence of their antagonism, but the matter was finally settled by the acknowledgment of the Supreme Court of the legality of Canonge's position. Judge Canonge's wife died in Paris in 1830. From the marriage were born four sons; Alphonse, Hypolite, Placide and Ernest. All were educated in Paris at the Collège Louis le Grand. Alphonse, following in the footsteps of his father, became an eminent lawyer and was prominent as the Superintendent of Public Schools. Hypolite Canonge, also a brilliant scholar, died at the beginning of his career. Placide, who married Miss Forstall, is remembered by his son, Placide, who for half a century was the bright light of literature in New Orleans. $\mathrm{He}$ was the brilliant collaborator in the "Abeille," the only French newspaper in Louisiana, and infused into it a vitality that it lost at his death. He was also the hero of his time in the gay world of society. $\mathrm{He}$ * Charles Palton Dimitry. 
wrote light comedies and proverbs in prose and in verse, which under his direction were acted in the private and exclusive salons of the society leaders, the rôles being filled by the beaux and belles of the "beau monde."

"Qui perd, gagne," a comedy in one act in prose, is remembered as one of the most successful.

"Le comte de Carmagnola," a drama of five acts, appeared in 1849, and was dedicated to Alfred de Musset; it was acted several times with great success in New Orleans.

Emma Canonge, married to Mr. George William Nott, lived to a great old age, surviving her husband so long that she was known only as the mother of her son, George William Nott. She was educated at a celebrated boarding school in Paris, where she was noted among her fellow pupils for her accomplishments. Like her brother, she possessed a mind of superior quality that never lost its Paris polish and finish. She remained a prominent member of society to her last years, preserving her beauty of face and distinction of manner, without a concession to time. In her loge at the opera, always in company with her son, her beautiful daughter-in-law, and her granddaughters, she was ever one of the distinctive features of the audience. It was in regard to her that a saying of Brunetière's was distorted from "what is not clear is not French," into "what is not charming is not Canonge." 


\section{CHAPTER XXX}

\section{DUBOURG}

\section{Dubourg-Charest de Lauzon-Bringier TUREAUd}

NOT four families but four names; four strands, 1 as it were, forming a single cord. We begin, as is due, with the most prominent one historicallyDubourg.

The ancestral line of the Dubourgs is set forth in a "maintenance de noblesse," dating from 1623, which was deposited in the Bibliothèque Nationale, Paris, in the eighteenth century by Pierre François Dubourg, "on the point of undertaking a long journey." The maintenance was discovered two centuries later by Henri Dubourg, an ex-officer of Hussars, who had been devoting many years to the study of his family. He and his younger brother Joseph (known later as the devoted adherent of the Comte de Chambord), belong to the Château de Morville branch of the family, the Seigneurs de Rochemont, near la Louvère, whence arises the Louisiana branch of the family.

The parent line runs back to the celebrated Anne Dubourg, Chancellor of Francis II, who was burned at the stake for favoring the Protestants in the sixeenth century, and from him to a great-grandfather, Hugues Dubourg, who lived in 1396. The Louisiana line begins with "M. Pierre François Dubourg, 
écuyer et Capitaine de Navire," the husband of Marguerite Vogluzan, who filed his "maintenance de noblesse" in Paris, before undertaking a long voyage. This was to St. Domingo, where he settled at Cap François and became proprietor of the great estate of Ste. Colombe.

Here, in 1766, was born his eldest son, the great Archbishop Dubourg - the first American Bishop, as he is called, of New Orleans. Pierre François Dubourg, known as the "Chevalier de Ste. Colombe," was born the following year and succeeded his father as proprietor of Ste. Colombe. He was educated in France and England. His estate being ruined and his home destroyed in the revolt of the slaves in 1793, he escaped to Jamaica, and there in 1797 married Demoiselle Elizabeth Etienne Charest de Lauzon, daughter of M. François Charest de Lauzon and of Demoiselle Perrine Therese de Gournay, his wife, who was the daughter of Michel Isaac de Gournay, Chevalier of St. Louis. All of them were described in the marriage contract as residents of the Quartier de la Marmelade, Island of St. Domingo, and now, by reason of the misfortunes of that colony, refugees in the town of Kingston, Jamaica.

The married pair came to the United States and after passing through New Orleans visited the elder brother, Abbé Dubourg, who lived in Baltimore, taking with them their little daughter Aglaé, then about nine years old. Leaving the child in Baltimore to be educated under the supervision of her uncle, the abbé, Pierre François Dubourg and his wife returned to New Orleans about 1800, and there 
made their home with the Chevalier Charest de Lauzon and his wife on Dumaine Street.

In New Orleans, Dubourg became, three years later, an American citizen and, profiting by the undeniable commercial advantages resulting to the city from its transfer to the United States, he set himself to the work of repairing his shattered fortunes. He succeeded in this to the full measure of his best hopes as a merchant; and he rose to high position in the social as well as in the commercial world.

He attained the rank of Major in the Louisiana Volunteers, the most distinguished corps of the militia, and in the records of the Cathedral is described as Collector of the Port of New Orleans, though there seems to be no official confirmation of such an appointment. He acted as Consul of the Kingdom of Sardinia, and filled the lucrative position of agent for his rich son-in-law, Bringier, and for many other of the wealthy sugar planters.

Although a good and practising Catholic, like many other men of his church at this time in New Orleans, Dubourg was a Mason and was elected Worshipful Grand Master of the Perfect Union Lodge, the oldest in the State, which in 1812 he formed into a grand lodge combining all the others, including the Polar Star Lodge to which Carlos Gayarré, the father of the historian, belonged. Dubourg was re-elected Grand Master in 1813 and 1814.

Dubourg acquired a large estate just above the city, "Plaisance," it was called, which is the origin of the name of the Pleasant Street of to-day. Louis- 
iana Avenue, the handsome boulevard just above Pleasant Street, runs through what was once the center of the Dubourg property.

He died in New Orleans in 1830, leaving five daughters. His eldest daughter, Aglae, educated in Baltimore under the supervision of Mrs. Seton, the founder of the College at Emettsburg, was married to Doradou Bringier. His four other, daughters were reared in the family home on Dumaine Street. Noémie married General Horatio Davis* of the Delaware family. Eliza married Seaman Field, Captain of the Thirty-second United States Infantry, of which regiment his father was Colonel. He became Colonel of the Louisiana Volunteers in the Mexican War and later AdjutantGeneral of the State of Louisiana. Their daughter married Bailly Blanchard, of New Orleans, long connected with the American Legation in Paris; his son was a Chevalier of the Legion of Honor. His daughter, the Vicomtesse Henri Perrot, resides in France. Victoire married James Harvey Field, nephew of Seaman Field. Their descendants have moved away from New Orleans. Adèle married her cousin, John Thibaut. They have many descendants in Louisiana.

But the glory of the family, as has been stated, was the Archbishop, Louis Guillaume Valentin. He was sent to France when but two years old to be

* General Horatio Davis, born in 1761, was made Colonel for his gallant defense of Lewes during the War of 1812. He was at one time Captain of the Port of New Orleans, and resided at "Ia Corderie," the famous old "Rope Walk" of early American New Orleans, just above the canal which was filled and turned into the handsome street called Canal, the shopping center of the city for half a century. 
educated for the church. At the time of the Revolution he was at the head of a Sulpician school at Issy, near Paris. He escaped from it, in disguise, to Paris, going to the superior branch of the school, rue Cassette, where it is still recalled that his disguise caused great amusement. The day of his arrival there, the revolutionists invaded the community on the rue Cassette and, seizing the head of it, flung him into prison and executed him shortly after. Dubourg was in hiding at a friend's when the dreadful massacres took place. Again fleeing in disguise, he made his way out of Paris and proceeded to Bordeaux, where he found his family; but being doubly odious in the eyes of the revolutionists as a cleric and as an aristocrat he fled again, this time to Spain. He sailed to America and landed in Baltimore in 1794, about the time when the negro revolt in St. Domingo was driving his family to America and destroying their fortune. Two years after his arrival in Baltimore, he became President of the Georgetown College. He gained for it a brilliant reputation among the universities of the United States. George Washington honored it during Dubourg's term with a formal visit.

The abbé founded St. Mary's College and had it raised by the Legislature of Maryland to the grade of university. As spiritual director of the famous Mrs. Seton, he assisted her in the founding of the Order of Sisters of St. Joseph (popularly known as the Sisters of Charity). He entered the ecclesiastical history of Louisiana in 1803, when the colony was separated from the spiritual jurisdiction of Havana and placed under that of the diocese of Maryland, then under Archbishop Carroll, who finally, after 
several years of troublous, unsuccessful efforts, selected the brilliant, energetic Abbe Dubourg as the Administrator Apostolic of the so-called (in ecclesiastical histories) "unhappy diocese" of Louisiana.

This opens the chapter famous in Louisiana history of the controversy between the administrator apostolic, the duly appointed ecclesiastical spiritual authority over the St. Louis Cathedral, and Père Antoine de Sedilla, the beloved and revered authority de facto over the hearts of the congregation. The episode is one of the most interesting in the history of Louisiana and has been made the subject of special study by a number of brilliant writers. Suffice it to say that as time passes and the brilliant students pass with it, Archbishop Dubourg emerges from the vexatious conflict with his indomitable antagonist, preserving his dignity and the undiminished respect of his flock, although Père Antoine still, in history, reigns supreme over their hearts.

Dubourg became the spiritual guide of the Ursuline Nuns while in New Orleans and, as he had assisted Mrs. Seton in her work in Baltimore, he helped them to establish their convent below the city.

At the time of the British invasion in 1812, he rendered such services to the people as to win their admiration and gratitude, despite even the antagonistic influence of Père Antoine de Sedilla.

On the day of the battle, in the chapel of the Ursulines before a congregation of frightened nuns and civilians, he celebrated a solemn mass, of supplication for the Almighty's protection and aid, the statue of Our Lady of Prompt Succor being displayed on the altar. The guns of Chalmette could be heard above the chanting of the holy office. 
At the moment of the elevation of the Host, when all hearts and eyes were bowed in devotion, a courier from the battlefield, rushing into the church, proclaimed in a loud voice "that the Americans were victorious."

In commemoration of this, by privilege granted by Pope Pius IX, an annual mass of thanksgiving is celebrated at the Ursuline Chapel. The Superior of the Convent of the Ursulines at the time of the Battle of New Orleans was, in the world, Victoire Olivier de Vezin, a direct descendant of the union of the Duvergé and Olivier families, among the very oldest in Louisiana.

The Mother Superior not only made a solemn vow to commemorate within the convent walls the God-given victory, but with her own hands ministered to the wounded on both sides. She turned the convent into a hospital, and with the other sisters tore up the convent linen for bandages for the wounded Kentuckians. The Kentuckians, as a token of their gratitude to her for the succor their wounded had received, were wont for many years afterward to send baskets of fruit to the convent on the anniversary of the battle.

When, a week later, the city held its official ceremony of celebration for the victory, Bishop Dubourg -robed in his vestments and followed by the priests and altar boys of the Cathedral-appeared at the great portal while from the choir inside resounded a great hymn of praise, and presented General Jackson with a laurel wreath, pronouncing an address that was then and is still considered a classic of history. In response, General Jackson, for all that he was a plain Methodist, made, in words that are also considered 
classical in their chaste eloquence, a pious return of the compliment, waiving reverentially all claim to the victory, ascribing it to divine Providence.

While in Rome in 1815 Dubourg was consecrated Bishop of New Orleans, the first Bishop of American New Orleans, and in France he established the Society for the Propagation of the Faith. Louis XVIII placing a vessel at his disposal, he returned to America, and proceeded to St. Louis, where he founded a college and ecclesiastical seminary at the Barrens on the Missouri. In 1818 he began the erection of the Cathedral of St. Louis and opened the St. Louis College in 1819. He also founded the St. Louis Latin Academy.

In St. Louis he spent much of his time in the sparsely inhabited frontiers and in the wilds of the Indian settlements. It was said of him that he was as much at home with the Indians in their forest life as he was in the archepiscopal palaces of Europe.

Visiting Washington thereafter, he prevailed on the government to co-operate financially with him in ameliorating the condition of the Indians in his diocese.

On his return to New Orleans about 1823, the Ursulines gave him their convent for his official residence, and he remained with them until he went to France in 1826, where he was successively made Bishop of Montauban and Archbishop of Besançon. He died in France.

According to his directions his heart was sent to the Ursuline Sisters of New Orleans. It is still piously preserved in its receptacle in a niche in their chapel.

A third son of François Pierre Dubourg and 
Marguérite Vogluzan, Joseph, known as "le beau Dubourg," came to America and visited New Orleans, but did not remain there. The fourth and last son, Thomas Patrice Dubourg, had two daughters, who were married in Jamaica, and one son, Arnould Dubourg, who, after being educated by his uncle in Baltimore, came to New Orleans to live. He studied law and was appointed judge in Plaquemines Parish in 1815. Later, he held one of the judgeships of the city. The only souvenir of him is a stray number of an old paper dated May 6th, 1820 , preserved as a curiosity in the Museum of the Cabildo, "l'Ami des Louis, the Friend of the Lawprinted in English and French, according to the ascription, by A. Dubourg and Louis Cherbonnier." The first number of the paper must have dated back to 1809 , as the copy in the Museum is number 2514, Vol. XI. How long Arnould Dubourg was joint proprietor of the paper is not known. He died unmarried in New Orleans in 1829. 


\section{CHAPTER XXXI}

\section{CHAREST DE LAUZON}

\section{$F^{R A N C ̧ O I S ~ C H A R E S T ~ D E ~ L A U Z O N, ~ o f ~ N e w ~}$ 1 Orleans, was the son of the last Seigneur de}

Lauzon. His father was the proprietor of the great Seigneurie de Lauzon in Canada, which embraced a lordly territory on the St. Lawrence River opposite Quebec. He was a young man at the time of the English-French War in America, and his home at Point Levis was a storm center during the fierce struggle.

The British occupied the Seigneurie and erected batteries at various points to bombard Quebec. Those who were living there at the time witnessed across the river the battle waged in the vast amphitheatre of the Plains of Abraham, where Wolfe's army achieved the victory that gave Quebec to the English. According to the tradition of the family, Wolfe's body, after the fight, was brought across the St. Lawrence and laid in the home of the Charests to await its shipment to England for final burial.

The Seigneur de Lauzon who, with others of his family, had borne an honorable part in the struggle, determined not to live under British rule. He sold the Seigneurie to the new British Governor of Quebec, James Murray, in 1765, and with his family proceeded to France, where he received high honors from the King in recognition of his services. He established a new home at Loches in Touraine. Three of his sons, Etienne, François and Philippe, 
went to St. Domingo and bought estates there. The estate of Etienne was called Charest; that of François, Lauzon; hence one brother was known as Charest de Charest, the other as Charest de Lauzon. Philippe was called Charest de Levis.

In Louisiana the family of Françios was known exclusively as de Lauzon, but this was considered merely as "a nom de terre," apparently, for the epitaph of his wife, in the old St. Louis Cemetery, bears only the family name as follows: "Ci-Git Elizabeth du Buisson, veuve de Charest, Néeau Cap François (Isle de St. Domingo) le 30 Aout, 1730. Decedée le 13 Novembre, 1816."

Charest, the eldest brother, was slain in the massacre of the whites by the negroes during the revolt at St. Domingo. François Charest de Lauzon and his family escaped to Jamaica, his youngest child, Marie Antoinette, usually called Adèle, being smuggled out of the house in a hogshead.

François Charest de Lauzon married Perrine de Gournay, the eldest daughter of Chevalier Michel Isaac de Gournay who, according to his burial certificate, was born in Brittany in 1728, and was descended from the ancient baronial house of de Gournay of Normandy (a branch of which was established in England in the time of William the Conqueror). Although he lost a part of his fortune in the insurrection, he yet preserved abundant means to take with him to Jamaica. His youngest daughter, Pauline, married "le Comte Roland Onfroy de Verres." The marriage contract, preserved in the archives of Jamaica, contains a page of titles and nobility ascriptions on both sides. Many of de Gournay's slaves followed him to Jamaica. He died 
there in 1813, and was buried in Holy Trinity Cathedral, Kingston, Jamaica.

François de Gournay, the son of Isaac, came to New Orleans and settled there. He married and had a large family, and his blood is represented in many branches in New Orleans. His granddaughter, the daughter of Charest de Lauzon, married Michel Dubourg de Ste. Colombe in Jamaica, who came also to New Orleans and lived with his father-in-law in the house on Dumaine Street.

The house is still standing, but it is indistinguishable from the others erected about the same time. Dumaine Street at that time was the aristocratic center of life in the city, as Orleans Street became later. Of all the streets of the "Vieu Carré," Dumaine has best preserved its original appearance. A stroll along its "banquettes" from Royal to Dauphine Street is like reading a page from an original manuscript written during the last days of the Spanish Domination and the first days of the American. If ghosts ever haunted the old dwellings of a city, they would hover around Dumaine Street, but straining eyes discover naught but the reality of to-day - the tenements and shops of Italians and Spaniards, who are camping, as it were, amid the tombs of an ancient cemetery.

François de Charest de Lauzon lived until 1819 and was buried in the old St. Louis Cemetery: "Ci-git François de Charest de Lauzon née à Québec au Canada le 12 décembre, 1744; decedé le Ier. février, 1819."

His death, as related in the family, was a pathetic one. Of his three children who had accompanied him to Louisiana not one was with him. His eldest 


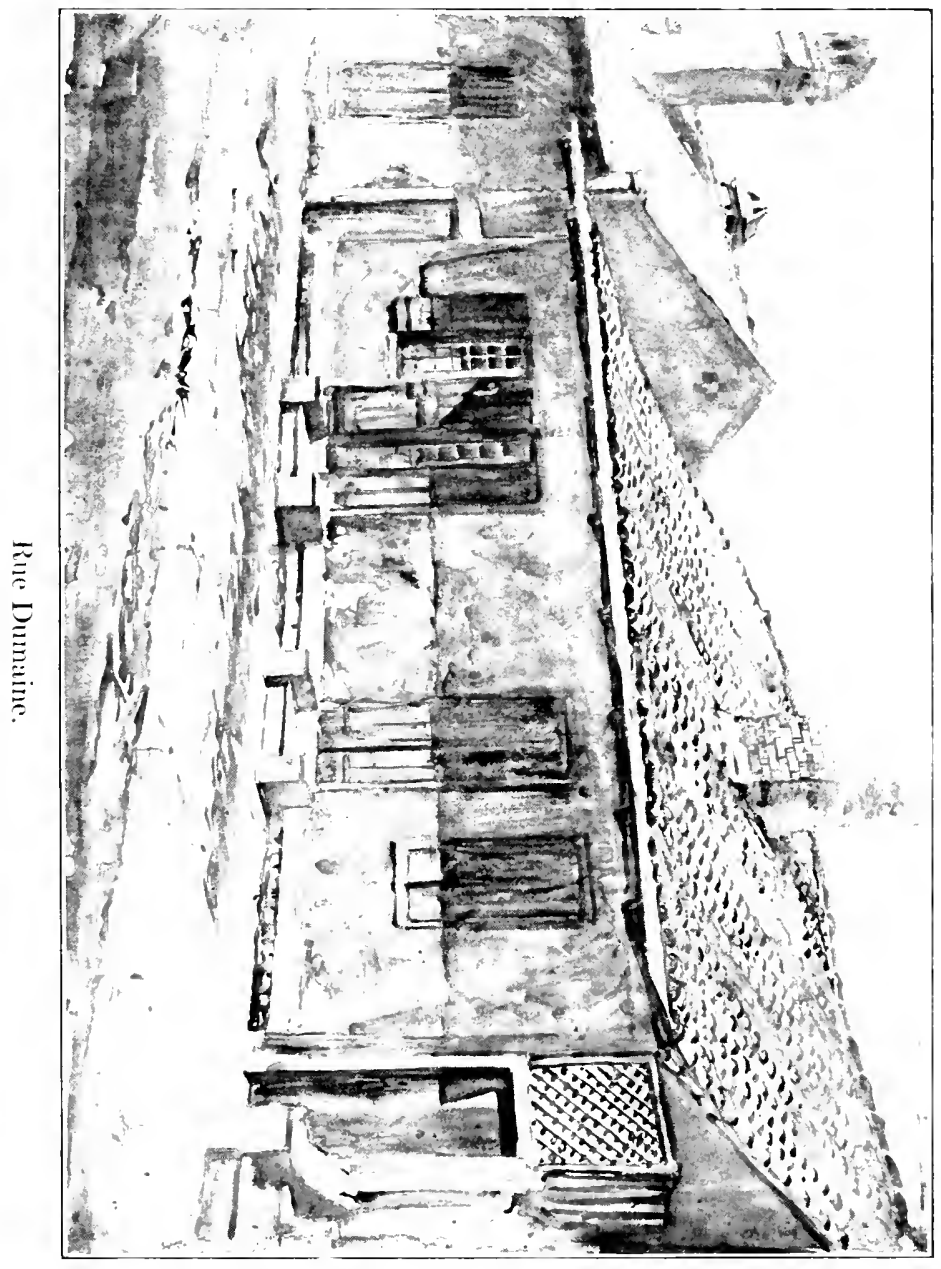



daughter, Etiennette, who had married du Bourg, had died in 1811; his only son, Bien Aimé, had been killed in a duel; and now his youngest daughter, Marie Antoinette, or "Adèle," had gone to join her husband, Jean Baptiste Thibaut, in Cuba.

The ship on which Madame Thibaut and her children had sailed was detained at the mouth of the river by unfavorable winds for so long a time that the journey was at last abandoned and it returned to the city. There were no conveniences, then, of telephone or telegraph, and Adèle had no thought but to reach home and her father as quickly as possible. He was seated in his armchair in the courtyard of his home in Dumaine Street, when she suddenly appeared before him. He struggled to his feet to embrace her-his face, his whole demeanor, expressed overwhelming joy, and then he fell back in his chair-dead. Adèle set out for Cuba again and reached her plantation near Santiago just in time to see her husband expire. After residing there a short while, she returned to New Orleans, leaving her plantation under the management of her uncle, François de Gournay.

Bien Aimé de Lauzon was born in St. Domingo and was brought by his parents to New Orleans and lived with them in Dumaine Street. He has unfortunately left but one record of himself in historythe duel in which he lost his life. He had taken his sister to a ball at the old Salle d'Orleans, where the brilliant society balls of a century ago took place, The room was crowded, and to procure a chair for his sister (the ladies after each dance returned to their places in a row of chairs extending round three sides of the room), Bien Amié seized one a few paces 
away, and passed it over the head of a young lady sitting there. She, starting up, affected great nervousness and alarm (the ladies of Bien Aimés family insist upon the affectation, for there was no occasion for nervousness or alarm), and the gentleman who had escorted her to her place felt called upon to interfere. His remarks about the trifling incident were such that Bien Aime at once invited him to the balcony in front of the ballroom, where words ensued that were followed by the gentleman brushing Bien Aimé across the face with his glove. A duel after this was inevitable-in fact imperative. It was arranged for the next day. The ladies of the family had, naturally, been kept in ignorance of it. On the next afternoon, Madame de Lauzon, the mother of Bien Aimé, and others of the family were seated on chairs placed before the house on the "banquette," as was the Latin custom of the day, in order to enjoy the fresh air. From passers-by in the street, Madame de Lauzon heard these words:

"That is sad about Bien Aimé de Lauzon."

"What's the matter?"

"Haven't you heard? He has been killed in a duel, and they are bringing in his body."

The shock almost killed the mother. No one had the courage to tell Adèle. She was to attend a ball that evening, and was allowed to make her preparations in ignorance of his fate. She actually went to the ball, no one daring to break the news to her.

The Salle d'Orléans is still standing on Orleans Street. It is now a convent for colored "Sisters." Little alteration has been made in the place. A balcony, as a century ago, runs across the front (the 
balcony to which Bien Aimé and his antagonist retired).

The act of burial of Bien Aimé is not recorded in the Cathedral. Its absence is explained by the fact that the last rites of the church were accorded only to those who had received the sacraments, and Bien Aimé fell dead at the first fire of his opponent. $\mathrm{He}$ was buried, however, in consecrated ground in the St. Louis Cemetery. Even the date of his death has not been preserved. But in the burial notice of his sister, Madame du Bourg de Saint Colombe, in 1811, it was stated that "ses cendres ont été exposées preiscelles de son frère."

In the old cemetery, the frequent inscription, "Mort sur le champ d'honneur" or "victime de l'honneur" show that the family of those killed in duels considered this mode of death an honorable one. All that was told by the witnesses of the affair was that Bien Aime fell at the first fire, shot through the heart, and that he had fired wildly. The dueling pistols used still exist in the family. They are of the finest English make. They were lent, it is said, for three different duels, with the result of death in each duel. After Bien Aimé's death they were boxed and never used again. They are now the property of Charles Thibaut, Esq., Harvard University.

Madame Lauzon lived after her son's death to an advanced age, dying when about ninety. Like her husband, she died in her chair. At the time she was the guest of her grandson, Arthur Thibaut, having just arrived from her daughter's plantation, the Hermitage. An informal entertainment was being given and refreshments were served. The old lady 
partook of them and, laughingly remarking as she held up her hands that her fingers were sticky from eating bonbons, retired to her room to wash them. Her maid accompanied her and left her while she went downstairs for warm water. On her return she found Madame Lauzon in her chair, asleep, as she thought. In truth she was dead. Her tomb also is in the old St. Louis Cemetery. 


\section{CHAPTER XXXII}

\section{BRINGIER}

THE Bringier family, whose name runs like a 1 golden tracery over the society of New Orleans during the nineteenth century, came into the colony during the very latest years of the Spanish Domination.

Emmanuel Marius Pons Bringier, * of La Cadière, near Aubagne, was the first to settle here. From a letter written by the "Chanoine Jean Baptiste Hypolite Bringier," of the Marseilles Cathedral, to a Louisiana nephew, we learn that the Bringier family of Louisiana descends from Ignace Bringier, a Judge of Limagne (ancien pays d'Auvergne), who was the father of Jean Bringier. He married Marie Douradon, daughter of Baron Douradon of Auvergne. They were the parents of Pierre Bringier, the father of Emmanuel Marius Pons. Pierre Bringier had an enormous family, which gave rise to the jeu d'esprit that he was the "father of nineteen sons and one canon." The canon of the Marseilles Cathedral was the younger brother of Emmanuel Marius Pons, and had been an émigré during the French Revolution.

Emmanuel Marius Pons left France in 1780, sailing in his own vessel with his young wife, Marie

* Taken chiefly from the manuscript notes of Trist Wood, Esq., a descendant of Marius Pons Bringier, who kindly loaned them to the author. 
Françoise Durand, to Martinique, where he and his brother Vincent became associated in business on a plantation. But not agreeing well as partners, they separated. Vincent lost his life in a shipwreck. Marius Pons, quitting Martinique, embarked again in his own vessel with his wife, slaves and household effects, and came to Louisiana. He acquired a plantation in the rich Tchoupitoulas district above New Orleans. Abandoning the place shortly afterwards, on account of the crevasses, Bringier moved to the Parish of St. James in 1785, where he bought, successively, five plantations and, throwing them into one, formed the famous Maison Blanche or White Hall plantation, which according to all accounts must be pronounced to be incontestably the greatest plantation Louisiana ever held.

What would be to-day a most valuable record of it, and a precious document in every way, has, to the enduring regret of local historians, been lost. This was the "Memoir" of Augustin, one of the old Bringier slaves, which he dictated to one of his mistresses, Madame Aurore Trudeau, who wrote it down in his patois, just as he spoke it. Only a vague reminiscence of it exists.

As traveling in the early days was done entirely upon the highroad running along the river bank, and no inns were in existence for the accommodation of wayfarers, the custom was for them to turn into any plantation they were passing and ask for hospitality for the night-hospitality that was never refused. Bringier, who could not but do things magnificently, improved upon this custom, as Augustin related it. He had outhouses built for the accommodation of passing strangers, with beds pre- 
pared and meals ready and slaves in attendance for them. Any stranger was made welcome. The rule at White Hall was not to ask his name or seek in any way to discover hisidentity, unless he chose to divulge them. He came and went as an unknown bird of passage might, but departed, rested and refreshed, his clothes cleaned and brushed, his linen washed. The enormous amount of provisions laid up in the plantation storehouses for this wholesale entertainment at Maison Blanche became a byword among the negroes, whose pride in it led them to exaggerate its quantity until, in truth, it became laughably absurd in its proportions.

The town house of the Bringiers, to which they came every winter, was on Canal Street; one of the three old houses, still remembered, built alike with massive Corinthian columns in front, called "the Three Sisters." One of these was subsequently converted into "The Grand Opera House." The Audubon Row occupies now the site of it.

"Melpomene" was their next place of residence in town. It had been owned previously by Seaman Field, the brother-in-law of Aglaé Dubourg Bringier. The name was always known as Melpoméne (pronounced in French), strangely enough before the street received its name in the due series of the Muses. Carondelet at that time was Apollo Street, a mere road through the bare country, with but one or two houses built on it. "Visiting the city" was the term used for going to Canal Street.

The eldest son, Michel Doradou Bringier, born on the plantation, was sent to Paris for his education. On his return to America he passed through Baltimore and was married to Aglaé Dubourg, who, 
as we have seen, had been placed in the convent there under Mrs. Seton for her education, and who was but fourteen years old. The marriage took place in Baltimore, where it created a great sensation on account of the remarkable beauty and the extreme youthfulness of the bride, but it was understood that it had been arranged by her uncle, the abbé, during a visit to New Orleans, with the full agreement of both families.

Doradou Bringier had never seen his bride before the ceremony except once, when, as a very small girl, she passed through New Orleans on her way to Baltimore. He declared then that she was the most beautiful child he had ever seen, and that he had fallen in love with her. Hermitage plantation was given the couple, and as a wedding present the bride received a beautiful doll. She remarked that she did not know whether it was meant for her or for her first baby.

The marriage turned out to be a very happy one. Aglaé lived to an extreme old age, preserving her charm and beauty to the last. She died in 1878 in her town house, "Melpomene," surrounded by her children and grandchildren.

The eldest daughter of Aglaé and Michel Doradou Bringier, Rosella, married Hone Browze Trist, the kinsman and ward of Thomas Jefferson; he became first American Collector of the Port of New Orleans; the youngest, Myrthé, married Richard Taylor, son of President Zachary Taylor, who became during the Civil War the dashing General Dick Taylor.*

* "Dick" Taylor, the son of Zachary Taylor, was born in Louisiana in 1826. After the Battle of Baton Rouge, in the Civil War, he was appointed to the command of the District of Louisiana, having 
Octavie married General Allen Thomas, at one time United States Minister to Venezuela. Louise married Martin Gordon, of New Orleans.

Nanine, the third daughter, married the Hon. Duncan F. Kenner who, looked back upon from the present times, looms up among the men of his day as a giant in intellect and force of character. He had a large family, but only two daughters and one son reached maturity. His eldest daughter, Rosella, married General Joseph Brent, of Baltimore. Their daughter, Nanine, is the wife of Thomas Sloo, Esq., of New Orleans.

One of the daughters of Marius Pons Bringier, Françoise, married "Christophe Colomb," who claimed descent from the great discoverer. Living in France, he had become involved in some plot during the French Revolution and had made his escape to St. Domingo disguised as a cook. But the insurrection and massacre there forced him again to fly. He came, as all the St. Domingo refugees did at that time, to New Orleans, and, as Trist Woods describes it, gravitated to St. James Parish and to White Hall plantation. He there married Françoise Bringier and became the proprietor of Bocage plantation, but instead of cultivating his fields, he spent,

already served with distinction in Virginia. His campaign in Upper Louisiana and on Red River was one of the brilliant military episodes of the Confederate War. After the close of the war he returned to New Orleans and lived with his family in the old Melpomene Street house. He had three daughters; one of them, Bettie, married Walter R. Stauffer; her sister, Myrthe, Isaac H. Stauffer-sons of the prominent and wealthy merchant and philanthropist, Isaac Stauffer, of New Orleans. The children of both sisters still proudly maintain the prestige of their blood and name in New Orleans. Louisette, the eldest daughter, died unmarried. 
we are told, the rest of his life cultivating the Muses. On moonlight nights he would betake himself to his boat or ornamental barge, ordering his men to row him up and down the Mississippi and, reclining on cushions beneath a fringed canopy, would pick his guitar and sing serenades to the moon. His wife, on the contrary, with the Bringier talent for business, mounting her horse at daylight, would ride over the plantation directing the work of the slaves. But husband and wife got on together famously, says the story-he wooing the Muses, she managing Bocage. 


\section{CHAPTER XXXIII}

\section{TUREAUD}

THE Tureaud family were originally Huguenots, 1 but they became Catholics before emigrating from France. The first Tureaud known in Louisiana was Augustin Dominique, born in St. Sauveur Parish, la Rochelle, in 1764, the son of Jacques Tureaud, "courtier," and of Françoise Guillon. He received a collegiate education, was dashing in conduct, talented and good looking, and, consequently, as we might say, became involved in a love scrape which brought about his being sent by his father to St. Domingo to take charge of a plantation he owned there.

In the revolt of the negroes and the bloody massacre of the whites, Tureaud was saved by the ingratiating qualities that distinguished him through life. His housekeeper, a mulatress, the wife of one of the ringleaders of the revolt, who knew therefore in advance what was impending, led him to the shore, where she had secreted a boat, and embarked in it with him and her two children. The cold was intense, the boat was an open one and all were thinly clad. They suffered cruelly. One of the children died on the second day out. The mother threw it overboard, and the little skiff drifted about at sea until it was picked up by a vessel bound for Baltimore. Tureaud by this time was lying unconscious in the boat. He always said that he had no idea 
what could have influenced the mulatress to save his life except an act of unconscious politeness on his part. When he came from France, ignorant of the customs of Martinique, he addressed the housekeeper as "madame," and although he does not say so, he most likely treated her with the consideration due a "madame."

A commission house in Baltimore received the refugee and communicated the fact to Tureaud's father in France, who remitted funds for his son's expenses, asking the firm to keep him in America. The surviving child of the ringleader and mulatress, although free, served in the Tureaud family, and his children were given European educations and subsequently returned to New Orleans, where they held good business positions.

Tureaud, after settling in Baltimore, made a number of voyages. In his diary he tells of being shipwrecked in the Pacific and residing with the Baron de Cambefort at the Mole of St. Nicholas, but unfortunately only one section of his diary has been preserved, that relating to 1801 and 1802. This is full of the exciting adventures, love affairs, etc., that befell amateur knight-errants on the Gulf of Mexico at that time. Once he was captured with his vessel by the English, once drifting about with a crew helpless from yellow fever, he put in to Vera Cruz for relief and, being refused by the authorities there, he sailed for New Orleans where his greatest adventure yet awaited him, for he met Marius Pons Bringier, who invited him to his plantation, White Hall, taking him up to it in his cabriolet. There his visit having terminated, he was about to leave when a heavy rain fell flooding the roads and de- 
taining him a few days longer. His host, more and more pleased with his agreeable guest and more and more reluctant to part with him, yielded at last to temptation and one day à propos of nothing offered him the hand of his daughter Fanny. Naturally, according to French customs, there were preliminary conditions connected with business to be arranged, but they were settled in a satisfactory way and the young man, duly accepting and accepted, was, as he wrote in his diary, raised to the seventh heaven of bliss over his good fortune. Fanny was only thirteen and, he confesses, not beautiful, but she was the daughter of the owner of magnificent White Hall! Tureaud returned to New Orleans where, he writes, congratulations were showered upon him. He went back to Baltimore and a year later presented himself to claim his bride.

Fanny did not keep a diary, but her account of the affair has come down to us nevertheless. She was in her room dreaming, as girls do, of her ideal in love and indulging in the usual romantic visions of marriage, when her father summoned her to his presence, and informed her that her hand had been promised to Monsieur Tureaud. She went almost into a state of collapse, but managed to stammer out that she bowed to the will of her father. Then, hastening to her room, she gave herself up to the wildest grief and indignation that she was to be given away to an old, gray-haired man. Tureaud was then thirty-eight years old, but this was, of course, aged to the eyes of thirteen, and his hair had turned gray when he fled from St. Domingo.

The marriage was celebrated at White Hall in 1803. While preparations for the ceremony were 
being made, the rebellious little bride spent her time weeping in her room, but in spite of her fears the union turned out to be the ideal one she had dreamed of.

Her father gave her "Union" plantation (so named for the happy event) as a wedding gift. The life spent there for both was a very happy one. Tureaud became a judge in the parish of St. James and during the Civil War served as Captain of Cavalry. But the bold, high-spirited daredevil of the diary suffered miserably in his old age from the effect of a wound supposed to have been received in a duel. He died at "Union" plantation in 1826.

He had sent to France for his nephew, Jean François Theodore Tureaud, to join him in Louisiana.

Theodore, born in Rochefort in 1791, had served in Napoleon's army, and was in the Treasury Department of the Marine in 1812. He arrived in Louisiana in 1814, and was followed, a year or two later, by his mother and two sisters. He became a Notary Public in New Orleans, and married Claire Conand, daughter of Dr. Joseph Conand of the same city. They founded a second line of Tureauds in Louisiana. 


\section{CHAPTER XXXIV}

\section{GARRIGUES DE FLAUGEAC-DE ROALDES}

E FLAUGEAC'S name has been written in the Jackson himself. In an order of the day after Chalmette, Jackson cited him particularly "for disdaining the exemption afforded by his seat in the Senate, and offering himself for the service of his country. He continued in this subordinate but honorable station, and by his example as well as exertions has rendered essential service to the country."

\section{As Gayarré describes it:}

"A little before daybreak, on the eighth of January, as soon as there was sufficient light for observation . . . a congreve rocket went up. It was the signal for attack. The British, giving three cheers, formed into close column of about sixty men in front and advanced in splendid order, chiefly upon the battery commanded by Garrigues de Flaugeac, which consisted of a brass twelvepounder, supported on its left by an insignificant battery with a small brass coronade; on the right was the artillery commanded by United States officers. An oblique movement was made to avoid the terrible fire of the Flaugeac battery, from which every discharge seemed to tear open the column, and sweep away whole files."

The gallant Frenchman, we are told, was a born fighter. Before coming to Louisiana he had drawn his sword under Republic, Consulate and Directory; and had sheathed it and come to Louisiana only when 
there seemed no further prospect for its use in France. He settled in Opelousas, one of the most beautiful and fertile parishes in the State, married there and devoted himself to the development of a large plantation. This was during the halcyon days of Louisiana, before politics infested the ways of public life, and a man's worth to his State was not measured by party balances. Thus, such a man as de Flaugeac was elected to the Legislature as Senator.

The House was in session when the British effected their landing in Louisiana, and with their gunboais dominated the lake and commanded all approaches to the city. There was a moment of panic and demoralization in the city. The Governor sent a message to the Legislature suggesting the expediency of adjourning for a specified time. The House considered an adjournment inexpedient and highly dangerous. Jackson, suspicious at this time of the Creoles, was anxious not only for the adjournment but for the suspension of the writ of habeas corpus. The House was firm in its belief that this would be unsafe, and Jackson issued a general order putting the city of New Orleans under martial law. It was in this moment of tension that de Flaugeac settled the question for himself by resigning his seat to volunteer on the field of battle; commending himself, as we have seen, in the best way to the good opinion of the general in command. After the battle he disappeared from the city and merged his life again in the interests of his plantation.

De Roaldes was his nephew, the son of his brotherin-law, who had been persuaded by de Flaugeac's letter's to leave France for Louisiana. De Flaugeac had married a de Roaldes. The wife of de Roaldes 
was Coralie Testas de Folmont, of the Château de Folmont, near Cahors, whose family had been known in France since the Crusades.

After a short trial of country life, de Roaldes left Opelousas and came to New Orleans, where he practised medicine for thirty years. His eldest son, Arthur, he sent to France for his medical education. The young man was engaged in his studies when the Franco-Prussian War broke out, and volunteered in the Sixth International Ambulance Corps. He was in the service of the Red Cross, in a deserted mill used as a hospital, near the River Meuse, and in close proximity to a pontoon bridge over which MacMahon's corps was retreating before the rapid advance of the Prussians, who were firing across the bridge regardless of the hospital work in the factory, filled with wounded and dying men. In his official report, the Surgeon-in-Chief gives the best account of what followed:

"Mons. de Roaldes charged himself with the perilous mission of planting our flag upon the roof of the house; a heroic action, which caused the enemy to stop firing against us, at the sight of the international colors."

For his gallant conduct the French Government offered de Roaldes the Cross of the Legion of Honor, but at that time it was considered to be the duty of Americans to wear no foreign decorations and the young man declined it.

He returned to New Orleans, equipped for his profession with a brilliant record as a man of nerve and action. He devoted himself to the special study of the eye, ear, nose and throat, and soon made himself known as a specialist of brilliant abilities in the medical world. 
De Roaldes lived in the part of the city inhabited principally by French, Spanish and Italian immigrants, and he was brought face to face with their teeming families whose children and babies were in sore need of special treatment beyond the means and intelligence of their poor, ignorant parents, with no relief possible except that offered by the general treatment of the overcrowded Charity Hospital, with its care for all the sick and wounded of three neighboring States.

De Roaldes, by degrees, was turned more and more into the highways and byways of charity, opening his office, and giving his rare surgical skill and his great gift as a diagnostician to the helpless and miserable mothers who brought their children to him.

The numbers that came or were brought to him soon overspread the limit of one man's time and attention. He associated others with him-young students who were glad to assist him for the opportunity of studying under him. With his hand to the plow, never looking back or releasing his hold, he traced the furrow that led to its predestined stopping place - the organizing of a scientific institution for the treatment of diseases of the eye, ear, nose and throat, where the poor, without pay, could seek and find the care and advice usually reserved to the rich.

The furrow was a long one and the years were heavy with work and fatigue before the end appeared; he was forced to appeal for money to accomplish properly what he had in mind. The money came, as he knew it would come, for the heart that conceives great designs is the heart that never despairs. At first, it came in scant driblets. The poor about 
him, knowing him, brought their mites. The country parishes responded, for they had sent their ailing children to him in the past. The negroes gave tooand it was the first time in history that they recognized their responsibility toward maintaining civic institutions. By the time the rich felt the urge to give their large donations and legacies, the foundations were assured; that is, a building had been rented. A great and adequate building, with full surgical equipment, now stands in the heart of the city.

But the story ends in the saddest of all tragedies, as human eyes see it. The Healer himself went unhealed. He who had restored the eyesight to countless others suffered himself years of hopeless blindness. At first, with his clear knowledge and unerring skill, he was able, as he said, to see with his fingers; and he still remained at his post, directing consultations; going to the hospital, which in truth was called "his hospital" every day; working for it until paralysis fell upon him; and as he could no longer see, now he could no longer move.

To mention family distinction after such a record is paltry. But although good wine needs no bush, a bush that produces the best of wine merits acknowledgment.

The de Roaldes belong to one of the old families of France always known for loyalty to Church and King. The château at Cahors, the family home, is still the family home, but on account of its great historic and artistic value it has been classified by the government as an historic monument, and taken over by it for preservation.

François de Roaldes was reputed the greatest 
scholar of his time (1519-1589). His cousin and pupil, François II de Roaldes, had so great a reputation that colleges disputed for the honor of possessing him, Toulouse finally gaining the prize. In the "Memoires Historiques" * is preserved the following letter from Henry IV:

"Mons. de Roaldes, the name which you have won among men of letters, makes me desire to know you otherwise than by mere reputation, and to testify to you how much pleasure it affords me to make known to you and all persons my good-will toward yourself. In the assurance of which I pray you to give faith to what the Sieur de Pira will say to you in my name.

"Adieu, Mons. de Roaldes. I pray you may continue in His holy keeping.

"From Pau, 20th, October, 1584.

"Your well assured friend,

"Henri."

The tablet of the handsome tomb in which Arthur de Roaldes' mortal remains were buried holds the list of the many decorations and medals awarded him by foreign governments for his good work among their subjects; but in truth he needs no such decorations or merlals, or even the letter of the King of France. His monument and enduring record is his hospital and the memory of him that is preserved in New Orleans.

* Facsimile of Henry IV's letter is in the historical collection at the Cabildo. 


\section{CHAPTER XXXV}

\section{PITOT}

\section{TACQUES PITOT DE BEAUJARDIÈRE and}

Joseph Roffignac, two young gentlemen of the nobility, fled from France during the Reign of Terror and came to Louisiana, settling in New Orleans where, strange to say, both in time filled the high and honorable office of Mayor.

They related on their arrival in the city the story of their last experience in their own country. Passing through Paris, they heard in the streets a rumble as of a great crowd approaching, with all the outcries and vociferations of a riotous mob. They stopped to see the cause of it. A surging, furious mass of people swept by them, filling the street, carrying on a tall pike the beautiful head of the Princesse de Lamballe, the hair dressed in court coiffure. Transfixed with horror, Pitot exclaimed aloud involuntarily and began to give expression to his outraged feelings, when he was touched on the elbow and a low voice whispered in his ear: "Marchez, marchez, monsieur; vous vous compromettez." And a plain laborer, "un homme en blouse," glided quickly from his side. This was more than enough; the two young men sped from the death behind them and disembarked from their native land the next day.

On arrival in the new world, they dropped their 
titles in order to conform to the republican spirit. Pitot was from Rouen and a thorough Norman in enterprise and energy. After witnessing the taking over of the colony by France from Spain and its hurried cession to the United States, he grasped the golden opportunities for business about him under the American régime, and was soon ranked with the prominent and wealthy merchants of the place. It is said that he established the first cotton press known in the city (on the corner of Toulouse and Burgundy Streets).

Etienne de Boré, as has been related, acceding to de Laussat's appeal to his patriotism, had filled the office of Mayor of New Orleans during the short episode of the second French Administration, but he refused to continue in office under the government of the United States, to which he was in principle opposed. The city with the territory was then under the rule of a Legislative Council appointed by the President. Laussat had abolished the Cabildo and established for the government of the city a Municipal Council, composed of a Mayor and twelve members. The council continued in office after the transfer of the colony to the United States, and it was re-established by Claiborne, who presided at its meetings, at which were present all of the original members with the exception of three who, with de Boré, for political reasons had resigned. Pitot was among the number chosen to replace these. On June 2nd, 1800, he was elected Mayor by the Council, with the approval of Claiborne, who afterwards was sworn into the office of Governor by Pitot.

New Orleans in her career has been honored or 


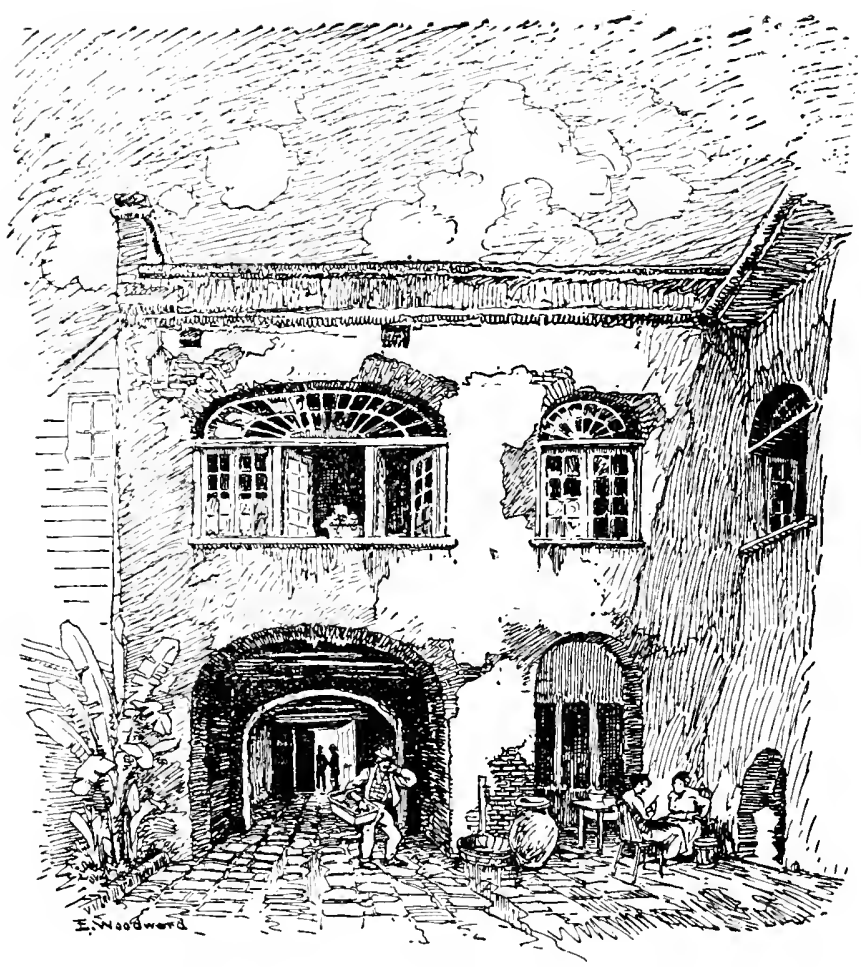

Toulouse Street, Near "Old Levee" Street 

dishonored by many kinds of Mayors. But the example of Pitot could produce only the Mayor that honored the city. Claiborne in his voluminous correspondence never lets his pen run over his name without a commendation of him.

The duties of the office of Mayor at that period were not light or easy. The citizens were in an ugly mood over the scamping, as they saw it, by the United States of the treaty with Napoleon, and they were in a state of constant ferment and indignation against the injustice put upon them by Congress. Public meetings were held, with violent orators denouncing the United States and clamoring for the rights of Louisiana. Pitot himself presided at one of these meetings and was on the committee that drew up the protest that was presented by a delegation to Congress. He presented the paper himself to Claiborne. Claiborne, always timid before the irrepressible nature of the Creoles, seemed never quite sure that they did not meditate some such coup d'état as they engineered against Spain; but in a letter to the Secretary of State, Madison, he writes:*

"I place much confidence in the good intentions and prudent conduet of Mr. Pitot, the Mayor of the city, whose influence is considerable, and who assures me that the peace of the city shall not be disturbed."

\section{He added:}

"The Louisianians are a zealous people and their lively support of measures, nay, their enthusiasm, may be easily excited; but I find they readily listen to good advice and are generally pacific and well disposed again."

* "Official Letter Books of W. C. C. Claiborne." Vol. II, Pl. 137-9. 
It was to the Mayor that the good Protestant Governor referred the complaint of the Lady Abbess of the Ursuline convent that a play was being produced at the theatre that cast ridicule on her convent. The play was withdrawn.

It is significant of the esteem in which Pitot was held in that he was appointed Vice-Chancellor of the University of Orleans, as the parent of the old Collège d'Orléans was grandiloquently called at its foundation-one of the first effects of the enlightenment of the American Domination.

Pitot resigned the office of Mayor in the summer of 1805 and was appointed by Claiborne Judge of the Probate Court of the Parish of Orleans, whose jurisdiction extended from the Balize to Baton Rouge.

Armand Pitot, his son, was a distinguished lawyer of the Louisiana Bar, and became clerk of the Supreme Court. He married a daughter of Montégut "fils," sister of the wife of Felix Grima. Mr. Gustave Pitot, the third generation of the name in New Orleans, was for many years a manager of the Citizens Bank, one of the oldest financial institutions in the city. The family group of the Montégut family, by Amans, in the Historical Society Museum, was an heirloom of the Pitot family. They have confided it to the keeping of the Louisiana Historical Society. 


\section{CHAPTER XXXVI}

\section{ROFFIGNAC}

COUNT LOUIS PHILIPPE JOSEPH DE ROFFIGNAC was a native of Perigord. He was of noble birth and had been a page to the Dowager Duchesse d'Orleans, the mother of Louis Philippe. At seventeen he received his commission from Louis XVI as a Lieutenant of Artillery, and served in Spain under his father who held an important command in the French Army. At twenty-four he was promoted on the field of action, for gallantry, to a captaincy in the Queen's Regiment of Dragoons.

He came to New Orleans, as has been related, with Jacques Pitot, having been compelled to fly from France to escape the guil lotine. Availing himself of an article in the Treaty of Cession which allowed French subjects equal privileges, including naturalization, with those conferred upon actual residents of Louisiana, he became automatically upon his arrival in Louisiana an American citizen. His appreciation of this high honor, as he considered it, he proved during his long life.

He does not seem, like so many of the new citizens at that time, to have opened his eyes to the money-making opportunities spread before him, but he undertook at once the serious fulfillment of civic duties. He entered the Legislature and served as State Senator for twelve years. Gallantly 
responding to the call of patriotism when New Orleans was threatened by the British, he became a soldier again and he was made a Colonel in the Louisiana Legion.

Roffignac was elected a director in the State Bank of Louisiana when the choice signified acknowledgment of mental ability and moral qualities as well; and finally he was elected Mayor of the city and was maintained in the office eight years.

It was a proud day for the city when he assumed office. He was, par excellence, the Mayor for New Orleans: an aristocrat, a gentleman, a man of letters and a clear-headed executive of ability.

Roffignac restored the finances of the city, strictly enforced the cleaning and policing of the streets, improved the public squares, and encouraged the establishment of institutions of education and charity. It was during his administration that in the Place d'Armes, along Esplanade, Rampart and Canal Streets, the sycamores and elms were planted, which gave to the city its foreign aspect for so long a period. The dear old trees, so kindly in the summer with their good shade, and so beautiful in the spring with their diaphanous white flowers, under which the old inhabitants used to promenade on Sunday afternoons, were destroyed eventually in one of the unsentimental and ignorant expressions of what was termed (as such attempts are always termed) civic progress and improvement.

The first contract to pave the mud streets with cobblestones covered with sand and gravel was made under Roffignac, and a regular system of lighting the city was introduced by means of large lamps with reflectors, hung from ropes fastened to high 
posts at the corners of the streets-an innovation hailed with delight by the citizens, who hitherto had been forced to furnish their own illumination by carrying lanterns on dark nights.

The city needed then just such an administrator. It was enduring then the roughest period of its existence. A never-ceasing influx of strangers poured through its streets-mostly traders from the wild West who came down the river in barges and flatboats, laden with flour and grain and immense quantities of cured beef to sell. They filled the streets at night with the noise of their drunken brawls. In their wake followed a horde of gamblers and disreputable men. Licensed gambling was permitted; the gambling dens were kept open all night. The night police were inefficient and too few in number for the size of the territory they had to guard. Assaults, robberies, crimes of all kinds were committed under the very eaves of the Cabildo; incendiary fires were of daily occurrence.

But all menaces to peace and order Roffignac met with the energy and courage of a soldier; and he imposed upon the lawless barbarians a regard for the dignity of the city. It was, however, toward the close of his administration that occurred a great civic misfortune - the terrible fire that consumed the State House. This was only a plain building on the lower corner of Toulouse and the Levee, with a broad gallery in front overlooking the river. A little garden at the side held a parterre of flowers and bouquets of tropical shrubbery. To the people, however, it was the stately "Hôtel du Gouvernement" of the French and Spanish administration, and consecrated as the stage of all the great political 
events of the colony's history. In it every Act of Cession of the colony had been registered, every "ordinance," or "Bando de Gobierno," promulgated. Under its roof was signed the warrant that condemned Lafrénière and his followers to their glorious death. Within its walls Governor Claiborne and General Wilkinson held their conference to thwart the designs of Aaron Burr; and there General Jackson had followed up his victory over the English by conceiving his high-handed design of dispersing the State Legislature at the point of the bayonet to get rid of the "traitors," as he considered them.

It had been built in 1761, under the French régime, and at the time of the disaster was the official residence of Governor Pierre Derbigny. In its upper chambers were held the Legislative Assemblies (the legislators and senators mounting to them by a rickety stairway that was always threatening to collapse). The State offices occupied the ground floor. Adjoining them was the public library, possessing, in truth, but a scant collection of books, but rich in rare and valuable manuscripts and historical records (to-day they would be considered beyond price). All were consumed, including an entire edition of the Code of Practice, and all but a hundred volumes of the new Civil Code.

On the day after the fire, the Legislature, which had been is session, assembled on the invitation of Mayor Roffignac in his public parlor to consult upon the selection of another building in which to continue their deliberations. It was decided to take the Orleans Ballroom, offered by that good citizen, its proprietor, John Davis.

Not only did Roffignac make the city proud of his 


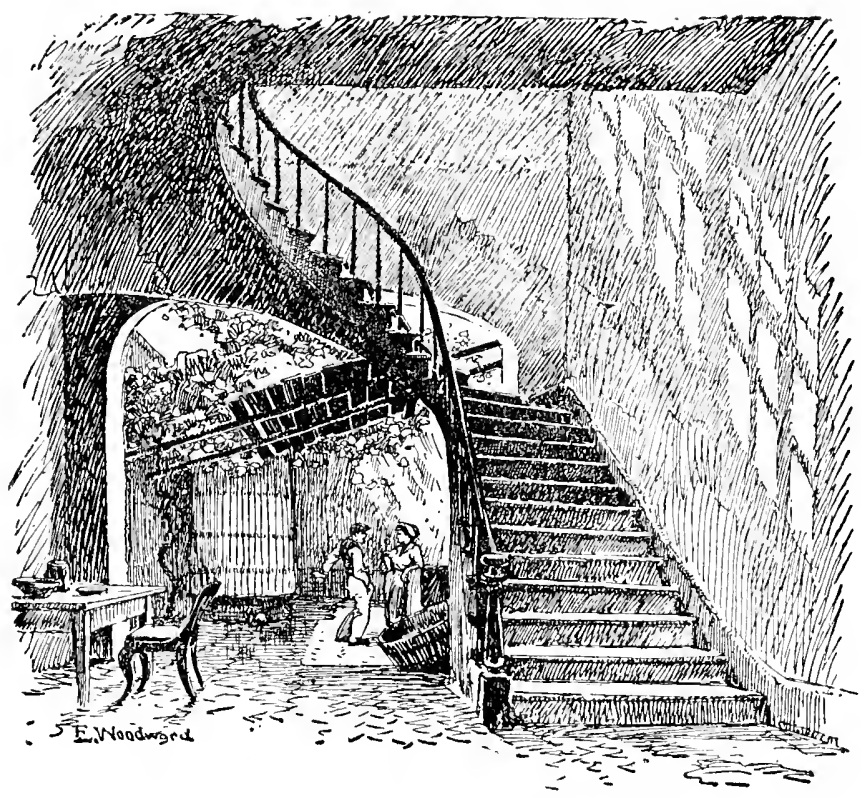

Porte-Cochère on Chartres Street. 


$$
\text { - }
$$


administrative ability; he flattered it by his undoubted position as a man of letters. He maintained frequent communication with the leading statesmen of France and an unbroken correspondence with Lafayette, who in 1825, when he made his everfamous and glorious visit to the city, was received by Roffignac under a great arch in the Place d'Armes with a speech that outshone Lafayette's reply.

He lived on Chartres Street between Dumaine and St. Phillippe, in close proximity to the Hotel de Ville and the Cabildo. He had married very happily a daughter of the good old family of Montégut. In 1828 he wrote his farewell address to the President and members of the City Council. It was a noble letter, which to-day, nearly a century later, moves the heart with its genuine and lofty sincerity, and true vision of the proper government of a city. His retirement from office was keenly regretted; he had devoted eight years of his life to the service of the city, and thirty to that of the State. "

Roffignac retired to France, where he had inherited from an aunt a considerable fortune; but he never could be induced to resume his title. To the solicitations of his wife and children he would reply invariably that he would remain plain Mr. Roffignac in France as he had been in America. He was cordially welcomed in Paris, and invited to luncheon at the Tuileries by Louis Philippe, who remembered he was Madame de Roffignac's godfather, and that Dr. Montégut had entertained him hospitably in the old days of his exile in New Orleans.

Roffignac's daughter married the secretary of the King's sister and his two sons married into families of distinction. His wife, "an excellent and chari- 
table woman," says Gayarré, lived with her daughter in Paris.

He retired to his château, near Prigueux. There Gayarré visited him, when he was over eighty years old, describing him thus:

"He pressed me tenderly in his arms, but alas wept bitterly. In the course of conversation I saw that he was an incurable sufferer and that life had become to him an insufferable burden. $\mathrm{He}$ deplored that he had ever left Louisiana, which had become his real home, while his native country had ceased in his eyes to retain that character after so long an absence from it. Now it was too late! too late to go back! His face was woebegone when we parted; he pressed my hand with energy and said in a voice that sounded like a sob: 'My dear friend, if you wish to meet a friendly eye on your deathbed-buy a dog.' He died shortly afterward, in his chair, from the accidental discharge of his pistol that he was handling." 


\section{CHAPTER XXXVII}

\section{ST. GEME}

THE memory of St. Gème is preserved in two 1 historical records. Gayarré, in a historical sketch of Pierre and Jean Lafitte, writes:

"Shortly after the war (1812), there was between two citizens of Louisiana an affair of honor which produced considerable excitement. Pierre Lafitte was the second one of them, and St. Gème of the other. St. Gème had no superior in New Orleans as to social position. He had distinguished himself under General Jackson as the captain of one of our uniformed companies, and was considered by the whole population as a sort of Bayard. Would St. Gème have consented to meet Lafitte in the capacity I have mentioned, if the latter had really been looked upon as a pirate?"

The other record leads us to the years before the Battle of New Orleans, when General Victor Moreau, condemned to exile by Napoleon, who was accused of being jealous of his brilliant rival, came to the United States, and in the course of his travels paid a visit to New Orleans, where he met with a reception of the best New Orleans kind.

The Governor, the military, the civil authorities, as well as the people themselves, turned out en masse in his honor, although the American authorities regarded him with a suspicious eye. He mingled freely with the French people, and was most cordial in greeting the French veterans in the city, many of whom had seen service in Egypt and on the Rhine. He played piquet with Pitot, discussed law with 
Derbigny, sipped wine with Claiborne, and played billiards with Marigny; and in every way made himself agreeable to the enthusiastic citizens. He was fond of horseback exercise and would make short excursions in the surrounding country. It was during one of these jaunts that, in the company of Major St. Gème, a man who had seen service in Jamaica, he was struck by the peculiar fitness of a piece of ground which formed a natural bulwark against an invading land force from below the river. Sitting erect upon his horse he critically examined the spot and descanted with warmth on the many advantages the locality offered if fortified as an intrenched camp.

His companion never forgot the incident and related it to Livingston who, in turn, related it to General Jackson on the memorable night of December 24th, 1814, when the first clash took place between the British and American forces. That spot was Rodriguez Canal, which Jackson selected and fortified-and immortalized by his heroic defense. "This," adds the author, "is a historical fact."*

The family of Henri, Baron de St. Gème, Marquis d'Ustou Montaubon, Chevalier of St. Louis, ascends to the year 1590. When St. Gème came to New Orleans is not recorded. It is known, however, that in the city he married the widow of Jean François Dreux, who was a Demoiselle Delmas, and that they went to France where they lived in the Château de Barbazan. They had but one son, Henri. The connection with New Orleans was resumed in later years when this son married Eugenie de Puèch, the daughter of Louis de Puèch and Althée d'Aquin, who

* Henry Castillanos, "New Orleans As It Was." 
was born in New Orleans and baptized in the old St. Louis Cathedral. The marriage took place in Tarbes, France.

The Puèchs belonged to an old Huguenot family who, after the Edict of Nantes, emigrated to Boston and from there went to St. Domingo, where they acquired vast property. They were driven out by the insurrection of the negroes and took refuge in Philadelphia.

The three children of Louis de Puèch were registered at the French consulate in Philadelphia as French subjects, and were sent to France for their education. Ernest was admitted to the school of St. Cyr, and was there when the Revolution of 1848 overthrew the republican government for that of Louis Philippe. He returned to New Orleans and thenceforth was counted among the foremost citizens of the place. He was the organizer and the first president of the Cotton Exchange. He enlisted in the Civil War and became a major of the Garde d'Orléans, and took part in several engagements. His age alone prevented his flying to France and offering himself in the last war. At his funeral, military honors were accorded him by a file of his old comrades of the Confederate Guards.

The Vicomte Henri de St. Gème died in 1901. His widow survived him many years. They had no children and she adopted Lucile, the granddaughter of her brother, Ernest de Puèch of New Orleans, and who at present is Madame Albin La Fonta. 


\section{CHAPTER XXXVIII}

\section{ALLAIN}

FRANÇOIS ALLAIN, a native of Brittany, was $F$ the first of his family to come to America. He had been an officer in the French Army and had fought in 1745 at the Battle of Fontenoy. Why he left his country for Louisiana is not known nor why he selected a home in Baton Rouge, "le poste des Attakapas," as it was called.

He brought with him two daughters and two sons, one of whom, Augustin, Captain of Grenadiers, founded the branch of the family known in New Orleans. Two sons were Valérien and Soathène. Valérien, the better known of the two, married Céleste Duralde, the daughter of Martin Duralde, a Spanish officer stationed at the Poste de Attakapas. Of the three Duralde sisters, one married John Clay, the brother of Henry Clay; another, Soniat du Fossat; and the third (Clarisse), C. C. Claiborne, Governor of Louisiana.

The mother of the Duraldes was a Perrault. She was from Canada and a descendant of Charles Perrault, the immortal author of the Fairy Tales. Valérien and Céleste Duralde had one son, Valérien, born and baptized in 1799, and three daughters, who became Mesdames Ursin Soniat, Valérien Dubroca, and George Eustis. Mrs. Eustis was the mother of Allain Eustis, who married Anais de Saint 
Manat. Her sons were James Eustis, late Ambassador to France; and George Eustis, in his day the "Beau Brummell" of New Orleans, who married Louise Corcoran, daughter of the Washington philanthropist. The daughters of this last couple were Mathilde, who married an Englishman and lived abroad; and Celestine, still living, who is to-day cited as the "fine fleur" of what ante-bellum New Orleans could produce in the way of a grande dame. To the grace of the Creole she adds the intellect of a woman of letters, and she is the author of several books connected with the life of her family in New Orleans, the profits of whose sale she has given in charity.

Valérien, the son, was sent to France to complete his education. He spent some ten years abroad, most of the time in Paris, where he frequented the society of men of letter's and indulged his cult for the stage. It is not surprising that, on his return to Louisiana, he found life on his father's plantation insupportably dull and resolved to live in the city, where he married Armantine Pitot, the daughter of Jacques Pitot de Beaujardière, the first American Mayor of New Orleans.

It was the day in Paris when gastronomy was an intellectual pleasure, and a good cooking a fine art. Gayarre used to say that the nearest approach to Parisian dinners that he had seen out of Paris were given by Valérien Allain. Fortunately he lived at a period when the old French market in the city and his father's plantation could supply the viands necessary. He seldom came home without two or three chosen friends to dine with him; and his wife, not to be taken unaware, was in the habit of stationing her butler in an advanced post of observation to give 
warning how many guests were with his master. During the meal, Allain, following the brilliant examples he had known in Paris, would rise from the table and, tucking his napkin under his vest, would proceed to the kitchen where, with the most perfect taste and skill, he would prepare such a chef d'oeuvre of culinary art as Dumas himself (Gayarré says) would have been proud of. His wines were all imported direct from France. His cook was the celebrated Gazoue, an African who had been the slave of Valérien's father on the plantation. Gazoue was sent to the best restaurants to finish him off in the art of cooking a dinner fit for gastronomes, and thus he contributed as much and even more, very likely, than his master to the success of the Parisian dinners.

Among the guests were such men as Victor Burhte, a poet as well as a good talker; John R. Grymes, a colossus of wit and learning; Etienne Mazureau, the finished orator who, it has been said by those who had heard both, surpassed even Henry Clay in eloquence -and always Gayarré, the host's intimate friend and schoolmate.

When his daughters grew up Allain gave a yearly grand ball, and every Thursday a small reception for intimate friends, following the custom of Paris again. The balls were ordered with the same fastidious regard to the Paris standard as his dinners; a full orchestra for the music, professional decorators for the rooms, and a supper that his guests thought could have set the standard for Paris.

Valérien was ruined by the Civil War and never recovered fortune, health or spirits afterwards. In the meantime, his uncle, Sosthène, lived on his great 
sugar plantation near Baton Rouge in the extravagantly generous style in force, at that time, among Louisiana sugar planters, until he was ruined. Ludicrously enough, he is remembered principally by the remarkable reputation achieved by one of his slaves; the bright, intelligent, good-looking mulatto born on his place, who was named Théophile, but called by his master "Soulouque," after the Haytien hero. He was his master's factotum, accompanying him every where.

After emancipation, Soulouque, as his talents demanded, quit menial service and entered the brilliant arena of politics, at that time opened to the negro. He rose easily above his contemporaries, whom he dominated by his intellect and fine address. He was elected State Senator; and, at Baton Rouge, further distinguished himself as a parliamentarian and a speaker. A gentleman of the Allain family, with whom Soulouque remained always on the best of terms, went to Baton Rouge out of curiosity to hear him, and, astounded, asked him where he had learned to make such fine speeches. Soulouque answered magnificently: "Did I not stand behind Mr. Allain's chair for years listening to the most brilliant men of Louisiana express themselves on public affairs? Hearing such talkers as Grymes, Hunt, Gayarré and Pitot, why should I not be able to speak better than these carpetbaggers up here?"

Celestine Eustis, in a paper published in the Courier des Etats Unis (Feb. 4th, 1912), adds another page to these good memories, which fits in with them like a leaf to its twig. Her aunt, Celestine Allain du Fossat, lived for years in Paris. She was pretty, aristocratic and distinguished looking. She was 
made to marry her cousin, Ursin Soniat, to effect a reconciliation between her father and his; "elle si peu raisonable, faisait un mariage de raison," exclaimed her niece. In consequence of a grave illness, her physician sent her to Paris, at that time the great remedy for all ills. She lived in an apartment in the Quartier de la Madeleine, in the same house that was occupied by Madame de Récamier. She seldom went out, except from time to time to make an appearance at a court reception, where Louis Philippe showed her the same friendship he did to all Louisianians. She received no society except a small group who were wont to gather around her on certain days, among them Chateaubriand and Lamartine. With Chateaubriand she formed a close friendship, and maintained a correspondence. Miss Eustis gives quotations from several of the original notes in her possession.

But Madame Soniat-and this is the important detail-was in such delicate health that she required constant and diligent care, which was given her by her maid, Anna Léandre, a colored woman born on the plantation, who had been her maid since childhood and whose devotion was such that her mistress used to say that she prayed God to take her first so that she might be spared the sorrow of surviving Anna.

This affection prompted her to send Anna's name to the National Society of France for the promotion of virtue, and Anna was awarded a gold medal. Madame Soniat wrote the account of it to New Orleans:

"The ceremony was touching and handsome. I was thrilled with emotion at sceing my dear Anna taking the arm of a young and 
handsome officer to go to the platform, where were the thirty judges and presidents, and more than five thousand spectators to receive the recompense she so well deserved. Each recipient received applause, but Anna was more warmly applauded than any one else."

\section{The official record of it is as follows:}

"Madame Anna Léandre, a woman of color, seventy-five years old; born in Louisiana, living in Paris. This excellent woman has been in the service of Madame Vve. Soniat for fifty years as maid and nurse, always showing unalterable attachment. Her parents and grandparents have served the same family from father to son for one hundred and fifty years. We recompense this rare example of fidelity by the award of a medal of honor. Paris, May 22nd, 1881."

After the death of Madame Soniat, Anna retired to a convent as a boarder, her mistress and friend having left her a comfortable pension. They lie side by side in Père la Chaise. 


\section{CHAPTER XXXIX}

\section{BEAUREGARD}

THE great name of Beauregard rises out of and 1 floats above the limits of city and State, like the genii of the "Arabian Nights" out of the fisherman's vase, never to be recaptured and put back into the small receptacle.

The earliest authentic records of the family go back to the year 1290, when Tider, surnamed "the Young," headed a party of Welsh in revolt against Edward I, King of England. Overcome and his followers dispersed, Tider took refuge in France and was received at the court of Philip the Fair; he there married Mademoiselle de Lafayette, maid of honor to Philip's sister, Marguerite, who afterwards married King Edward.

The entreaties of his wife induced the King to give Tider a post in Saintonge, the part of the British possessions in France. Eventually Tider lost the royal favor. He returned to the service of France and died in the neighborhood of Tours. His son returned to Saintonge, and through powerful influence he obtained a position under the English crown. To propitiate the King, to whom the name of Tider was odious, he changed it to Toutank, which gradually was changed to Toutant.

Toward the close of the sixteenth century the last male descendant of the Toutants died, leaving only a 
daughter, who married Sieur Paix de Beauregardhence the family name Toutant-Beauregard, the de having been dropped and the hyphen substituted.

Jacques Toutant-Beauregard was the first of his name to come from France to Louisiana. He was sent under Louis XIV as commandant of a flotilla to bring assistance to the colony and carry back timber for naval constructions. He succeeded so well in his enterprise that on his return to France he was given the Cross of St. Louis.

He afterwards settled in Louisiana, where he married Demoiselle Madeleine Cartier. Three sons were born to them; one of them, Louis Toutant-Beauregard, married Mademoiselle Victoire Ducros, the daughter of a planter in the parish of St. Bernard, who had filled several offices of trust under the French and Spanish governments of Louisiana. They had one daughter and two sons; the younger son married Hélène Judith de Reggio. Several children were born of this union; the third of them was Pierre Gustave Toutant-Beauregard, the Confederate General.

The Reggios of Louisiana descend from the Dukes of Reggio and Modena, of the illustrious house of Este. François Marie Chevalier de Reggio (akin to the reigning Duke) having distinguished himself under the Duc de Richelieu in the French Army, was given a captaincy by Louis XV, and was shortly afterwards sent to Louisiana with his command. When Louisiana became a part of the Spanish possessions, the Chevalier de Reggio was appointed Alfarez Real, or Royal Standard Bearer.

Of his marriage with Miss Fleuriau two sons were born; the younger one married Louise Judith Olivier 
de Vézin, who became the mother of Hélène Judith Olivier de Vézin, who became the mother of Helene Judith de Reggio, the mother of the future General Beauregard. He was born on his father's plantation in the parish of St. Bernard, near the city of New Orleans, on the 28th of May, 1818. When not more than eight years of age, he was sent to a small primary school near the city, where he commended himself by his studious habits and good disposition. His dominant trait even at that early age was a passion for all things pertaining to military life. The sight of a passing soldier, the beating of a drum, would so excite him that he would forget everything else.

The oft-repeated anecdote illustrates this. At the age of ten he was prepared for his first communion. The appointed day for the holy ceremony arrived; with his mother, his elder brother, and his teacher, he was seated in one of the front pews of the old St. Louis Cathedral, awaiting the solemn moment when he was to approach and kneel at the altar. The moment came; his mother touched him on the shoulder to admonish him that it was time to walk up the aisle. He arose, deeply impressed with the solemnity of the scene, and stepped reverently forward as he had been directed to do. Halfway up to the altar, the roll of a drum resounded through the Cathedral; he stopped, hesitated and looked toward the family pew, where anxious eyes kept urging him forward. The roll of the drum was heard again, more distinct and prolonged. Hesitation vanished at once. Turning his back on the altar, he dashed through the church and disappeared at the door, to the utter horror and dismay of his loving relatives. 
At the age of eleven, he was taken to New York where he remained four years under the tuition of two retired officers of the French Army who had seen service under Napoleon. At sixteen, he entered West Point; his parents, who had persistently opposed his wish to obtain an appointment there, finally yielding, overcome by his entreaties. $\mathrm{He}$ went through his four years' course with no less distinction than success; and was graduated second in a class of forty-five. In the same year he was appointed Second Lieutenant in the United States Engineers.

His life now goes into the military history of the United States. His services in the Mexican War belong to the brilliant record of the army. From 1853 to 1861 he remained in charge of what was then called the Mississippi and Lake Defense of Louisiana. During that time he also superintended the building of the Custom House at New Orleans.

In 1860, he was appointed Superintendent of the Military Academy of West Point, but filled the position only a few months. Resigning in 1861 from the service of the United States he returned to New Orleans and volunteered as a private in the old Creole Corps, the battalion of the Orleans Guard, composed of the élite of the Creole population. When the Louisiana State forces were organized, he was appointed Brigadier-General.

He had married shortly after his graduation Laure Marie Villeré, the granddaughter of the patriot who had been shot by the Spaniards, and the daughter of Jacques Villeré, the first Creole Governor of Louisiana. Three children were born to him: two sons, Henri and René, and a daughter, Laure. The sons, while mere boys, became officers 
on his staff during the Civil War. Henri passed from New Orleans eventually. René became a judge in the parish of St. Bernard, and for many years filled the office with distinguished ability. Laure married Mr. Charles B. Larendon, of Atlanta. She died before her father, leaving one daughter, Laure, who resides in Atlanta. Judge René, Beauregard's son, is the sole male survivor of the family; he bears his grandfather's name.

After the death of his first wife, General Beauregard married Caroline des Londes, daughter of one of the prominent planters of the State (her sister had married John Slidell, the Confederate Commissioner to France). His second wife died during the war.

At the invitation of the Louisiana Historical Society, Rene T. Beauregard wrote a short sketch of his father in his social and domestic life-the simple, tender and frank memory of a son.

"My first recollection of my father," he says, "is when he left Louisiana for the Mexican War. I remember his disappearing figure and rapid footsteps down the stairs of our old St. Louis Street home, and my mother's tears as she stood with her two children at the head of the staircase."

When General Beauregard returned to New Orleans, after the surrender of the Confederacy, he had been a widower for more than a year. Moreover, he found society disorganized, families extinct, and business paralyzed. It is a painful memory that is tacitly now ignored. He became a mendicant for work at doors that were shut in his face (even as Charles Gayarré was then making the experience).

"Condemned to forced inaction," proceeds the son's relation, "and to wait the unknown results the victor had prepared for the 


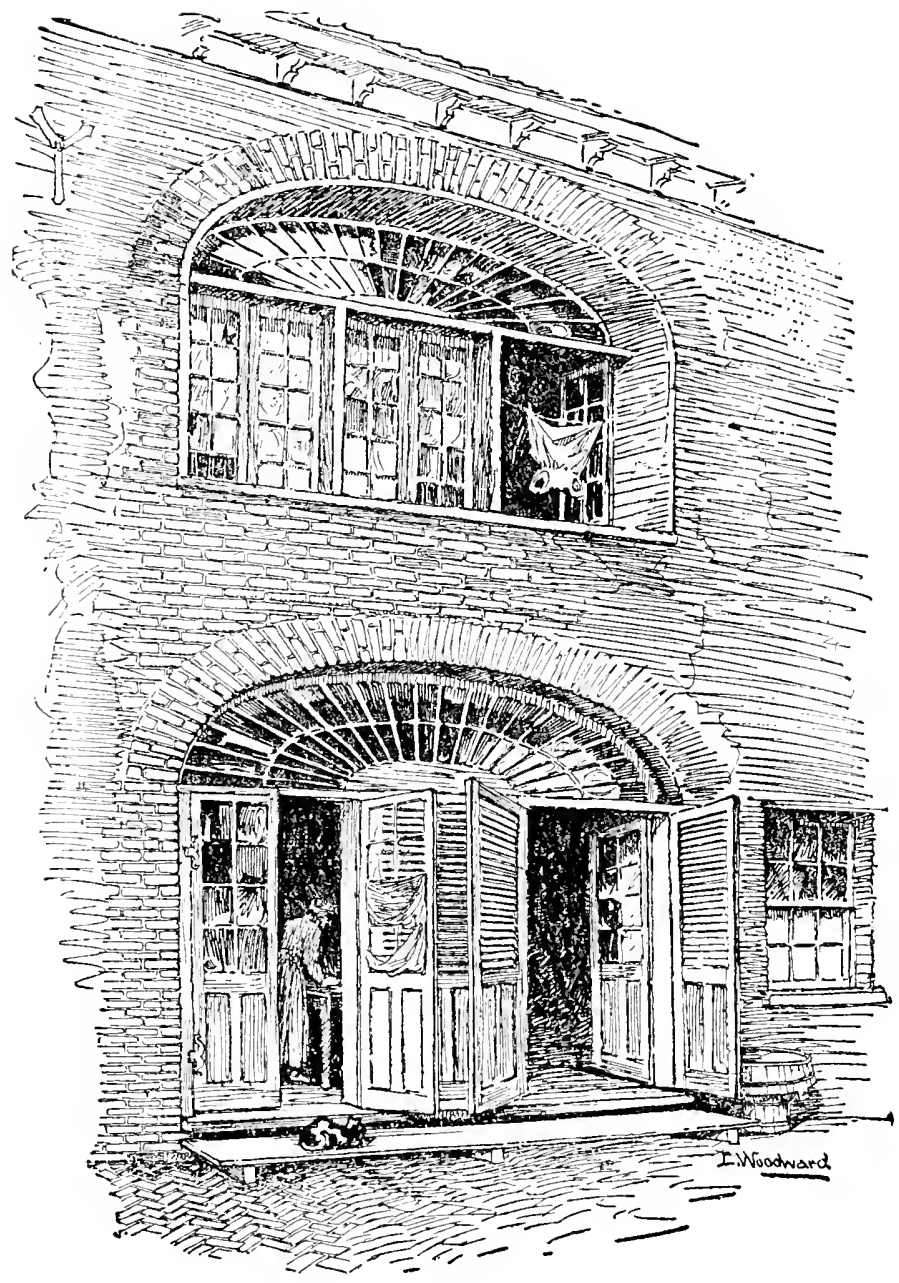

Rampart and St. Peter Streets. 
vanquished," he began, "while the facts were still fresh in his mind to write the historical outlines of the great drama in which he had played a leading part, primarily, to safeguard his reputation from the imputation of errors that he had not committed, the recollection of which rankled in his mind still suffering and sore from the afterwar conditions. After much labor and time consumed in collecting and verifying the documentary evidence of what took place. . . ."

(evidence which has cleared his name and reputation beyond even the suspicion of military errors) two compendious volumes were published: "The Military Operations of General Beauregard," by Alfred Roman, a friend to whom he modestly committed the writing of the book.

As a guide to the understanding of the confused condition of military affairs in the South during the first years of the Confederacy it has attained a first rank in such publications; but at the time his son frankly confesses the volumes did not please or satisfy all. Gayarré, who made a study of the work and reviewed it in a masterly way, gives his opinion that "no future history of the war can be written without the study of it."

The General descended to the rank of a private citizen, practising "the dignified submission to defeat" that he had counselled others. He accepted with soldierly acquiescence the penalties he had incurred, and drank his cup of humiliation with even courtly grace.

During the long life that followed, he mingled in simple cordiality with his fellow citizens, enjoying social intercourse and the pleasures that chance threw in his way, banishing from his face any trace of the bitterness that must have welled from his heart. He became a familiar figure on the streets and in the theatres and popular meetings. Parents 
used to point him out to their children, who will transmit to their children the tradition of the soldierly figure of the old gentleman with white hair and mustache, carrying his head like a marshal of France-always simply dressed, always gracious of manner, smiling kindly in response to even the shy salute of a newsboy. For eleven years he conferred upon the Athénée Louisianais the honor of serving as its president; and he punctiliously and generously fulfilled all the duties required by the position. His official addresses, delivered in the perfect French of an academician, remain models of amiable and enlightened scholarship, restricted by the terse eloquence of the soldier.

He died in 1893, and was accorded that belated compliment of a grand funeral. His body lay in state at the City Hall, while great throngs paid obeisance to it. He was buried in a simple tomb in the vault of the Army of Tennessee, a soldier among soldiers. His son, René, lies near him in the same vault, his daughter Laure not far away.

A monument has been raised to him at the entrance of the City Park, where ends the old road which was used by the Indians as a portage, and which Bienville traversed on his way to found the city-the road that was trod by all of Bienville's followers, the sons of France and Canada, the makers of the city. Old forest oaks are still standing that were alive then. The gray stone figure, mounted on a battle charger, looks steadily ahead, bidding as once in a battle charge, "Not go but follow." Not far away, within bugle sound, is the home for old Confederate soldiers a vanishing wisp of gray cloud after the stormbut they were the soldiers of Lee, Jackson and Beauregard. 


\section{CHAPTER XL}

\section{ALCEE FORTIER}

HE does not yet belong to the past of New H Orleans. His place among us in the family of its citizens is still warm. His face and figure are still familiar to the eye, his voice, distinct to the ear. The time for the cool, detached historical appreciation of him has not yet arrived. It belongs to the future to which he can confidently be remanded. In truth, his life was a compact one of work; to make a succinct account of it requires but small assistance from personal detail. The name appears in Louisiana in 1740 for the first time, in the person of Michel Fortier "armurier du roi," a man evidently of forceful character, who took part in the Galvez exploits.

He married Félicité La Branche, a daughter of an old and distinguished Creole family; and in 1803 he was appointed by Laussat a member of his municipal council, and was one of the four commissioners who did the honors of the beautiful ball offered to Madame Laussat by the City Council during which the pretty incident, unique in American festivities, took place. In the midst of the supper, a turtledove alighted on a branch of roses before Madame de Laussat with a note in its beak containing the verse, written by one of the commissioners entitled, "Portrait de Madame de Laussat." 


\author{
"On voit en elle \\ Les vertues et les attraits; \\ On voit le portrait fidèle \\ De son ame dans ses traits, \\ Affable, sensible et bonne. \\ Vertueuse sans fierté \\ Et belle sans vanité, \\ Tout est charme dans sa personne."
}

He was one of those selected by Laussat on the eve of his departure from the province to receive the curious testimonial of his regard. "Knowing,"* says the record, "that they were all ardent hunters and preferred French powder, he distributed among them the supply of powder left, belonging to France; giving it away in small presents ranging from thirty to forty-five pounds."

In 1814 he served on the Committee of Veterans who were mentioned in General Jackson's report as "attending to the preservation of police and civil order in the city and contributing to dissipate the alarm created by the approach of the enemy; besides affording relief to the sick and wounded and procuring subscriptions for the purchase of clothing for the soldiers who had left their homes unprovided for a winter campaign."

His son, Michel Fortier, Jr., a Colonel of Militia in the army under Jackson, was the father of Florent Fortier, who is mentioned gracefully and gratefully by his son Alcée in his book "Louisiana Studies" as "a true representative of our Creole planters, whom the war had ruined, but who were to the last energetic and noble." Alcée Fortier includes him among Louisiana poets, citing some of his verses to $\mathrm{La}$ Salle.

* Fortier's History of Louisiana. Vol. II, pp. 292. 
Florent Fortier married Edwige Aime, the daughter of Valcour Aime, one of the richest sugar planters of St. James Parish. Their son, Alcée, was born on the great plantation in 1856, the source of his first childish memories, which he was fond of incorporating into the relations of his later life. The date of his birth fixed his destiny as a later generation sees it that of a child born in the luxury of wealth and plunged by the results of the Confederate War, into poverty. In one of his pages he gives some of his earliest experiences of the war:

"After the fall of New Orleans, the Federal gunboats ascended the river, and being attacked by the Confederate batteries, as they passed bombarded the plantations on the bank. How well do I remember the flight of our whole family to the river front to seek the protection of the levee whenever a gunboat was coming. There we stood behind the levec, my sisters and myself, our schoolmistress and our nurses, while our father stood on the levee to look at the gunboats and at the shells that generally passed over our heads but occasionally were buried in the levee and covered us with dust. Our house was never touched by the shells, but the houses of a number of people our relatives were considerably damaged. I remember seeing cart loads of shells strewn in the yards. I remember also the holes dug in the ground covered with thick beams and several feet of earth, the inside arranged like a comfortable room and filled with provisions of all kinds. Then came the Federal soldiers in garrison on the plantation . . . the insolence of some of the liberated slaves, the temporary arrest of my father and grandfather . . . the serio-comic scenes at the pro- 
vost marshall's court . . . then the flight of the family to the Teche and the pillaging by the conquering army; the return home, and then complete ruin. From this ruin, we sons of rich planters have now partially recovered, and the men of 1894 who were boys in 1862 do not keep any unkind remembrance of war times."

Like most patriots of his time, Florent Fortier feared poverty only as it would affect the future of his children; and like them he made heroic efforts not to replace the vanished luxuries of wealth but to educate his children. Alcée was given the opportunity of attending the University of Virginia, but unfortunately could not complete his course there owing to ill health. Returning, however, he put his shoulder to the work of educating others; he became an instructor and then principal of the preparatory department of the University of Louisiana. In 1880 he was chosen as professor of French in the university and retained the position when the University of Louisiana became the Tulane University, and then he became also professor of Romance languages. This was his great work in the State, giving the French language a standard place in education. $\mathrm{He}$ will always be accounted one of the foremost educators of the South. In New Orleans he was active in all intellectual work. He became President of the Athénée Louisianais and was President of the Louisiana Historical Society from its reorganization in 1894 until the time of his death; President of the Modern Language Association; member of the State Board of Education, and of the State Museum Board.

His work as a writer and as a lecturer proceeded from his educational reputation; he became an assidu- 
ous worker in both fields, contributing many publications to general literature and philology. His most valuable contribution, according to the estimation of contemporary beneficiaries, is his "Louisiana Studies," published in 1894, which) contains fragments of his folklore and personal reminiscences and his original researches into the literature of Louisiana, compiling with precise accuracy the list of all authors, French and American, from the beginning of the colony to the time of his writing.

For school purposes he made incursions into the history and literature of France, and produced therefrom the good educational papers on "Le Château de Chambord," Sept grands auteurs "du XIX Siécle"; "Histoire de la Littérature Française"; "Précis de l'Histoire de France." His last work is monumental: "The History of Louisiana" in four volumes, published in 1894 by Manzi, Joyant \& Co., New York.

He died in 1914 and lies buried in his old family tomb in St. Louis Cemetery. 

APR 7992 
LIBRARY OF CONGRESS

\|\|\|\|\|\|\|\|\|\|\|\|$|\||$ 00145408568

ins
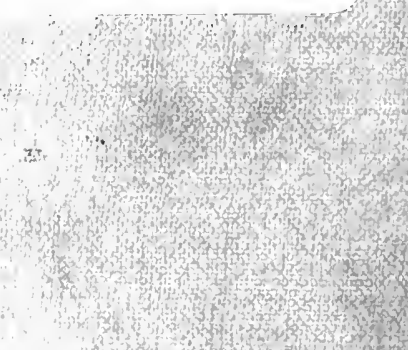

1.

and Hand

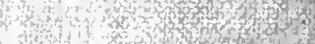

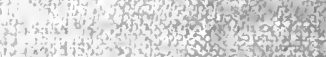

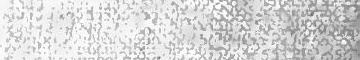
aring

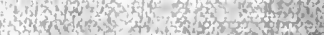

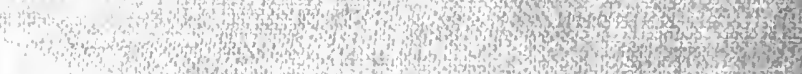
Pat W

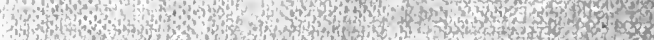

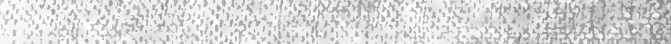

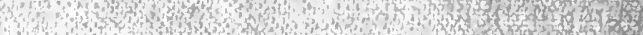
W. , (1)

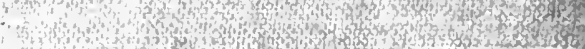
(1)

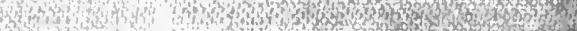
ats

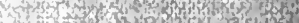
W.

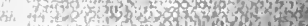

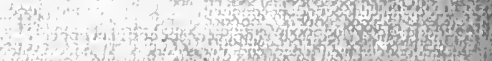

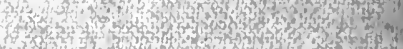
Wh.

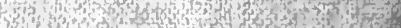

